\title{
QK

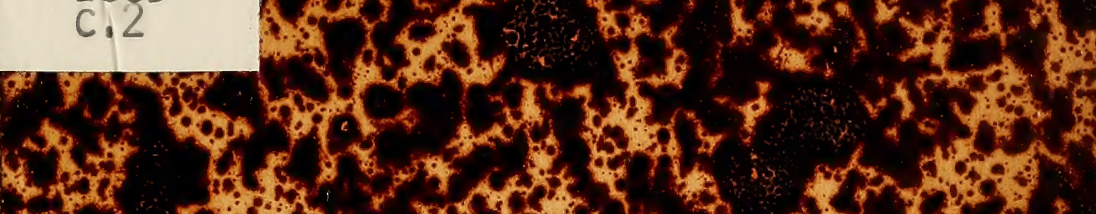
of ${ }^{2}$.

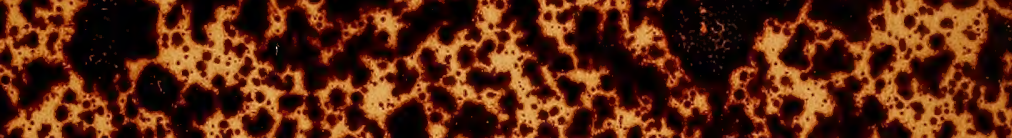

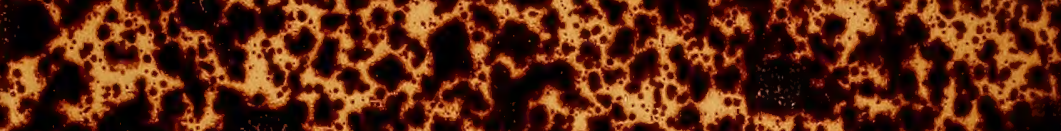

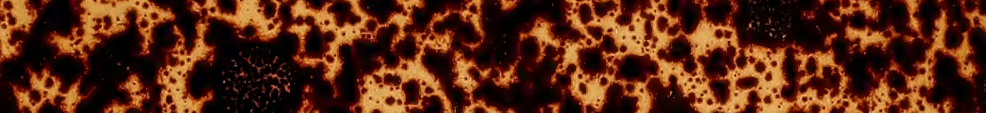

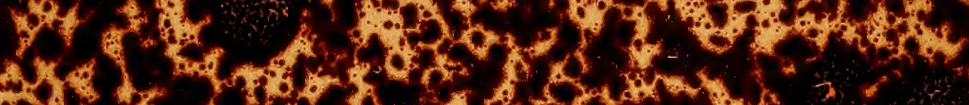

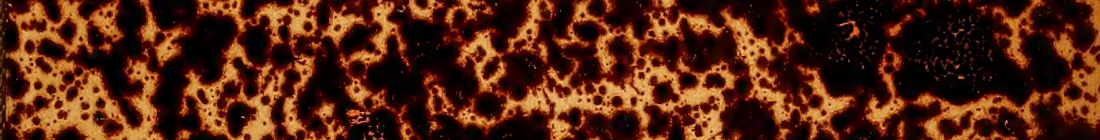

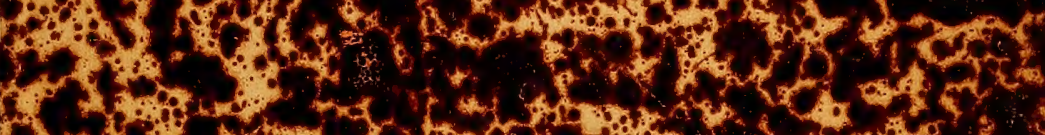

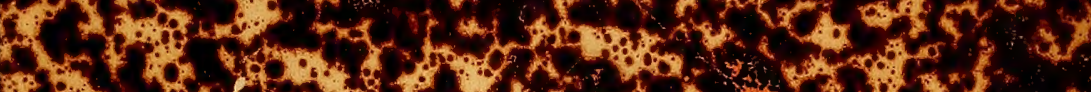

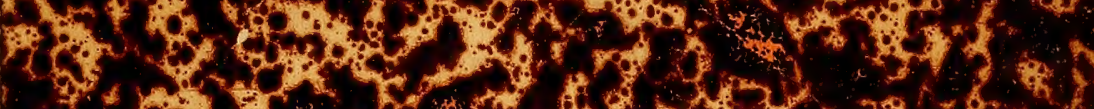

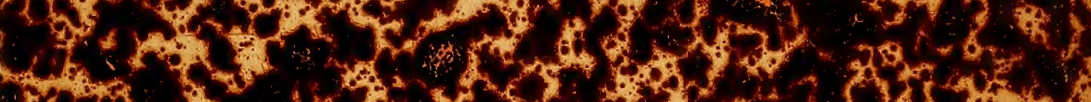

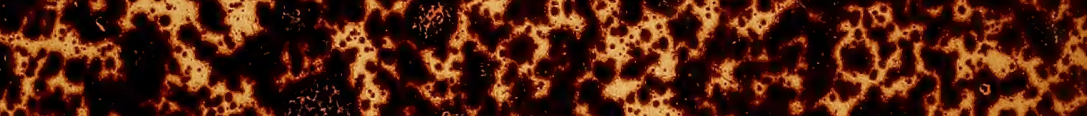

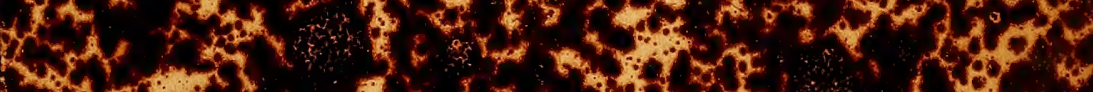

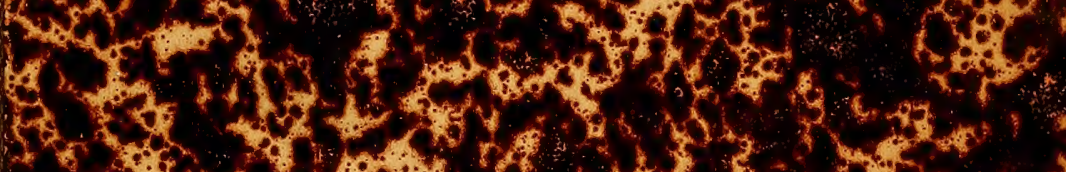

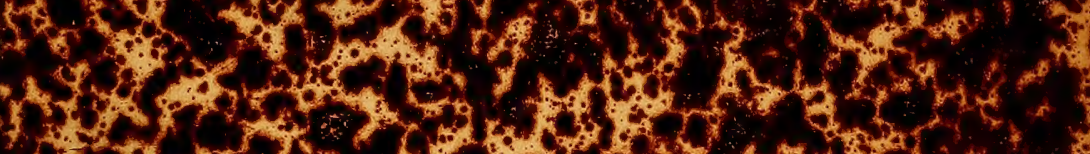

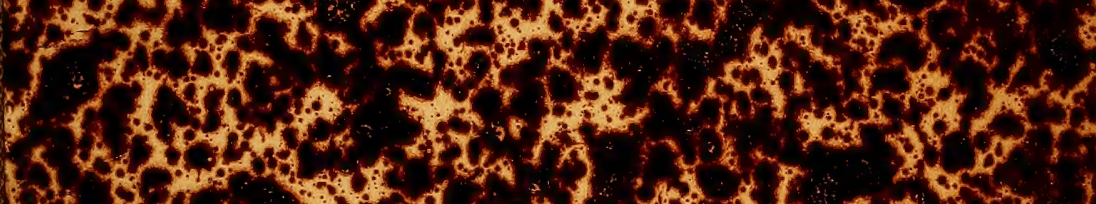

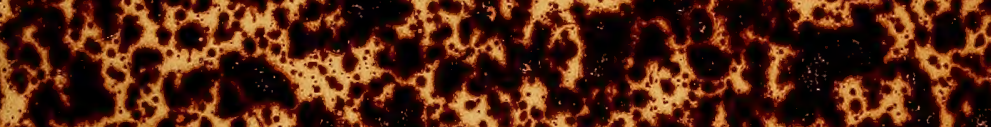

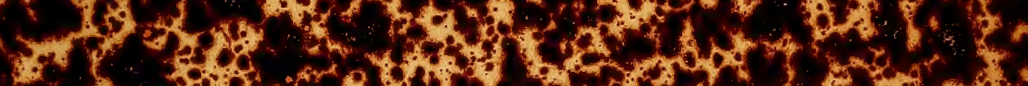

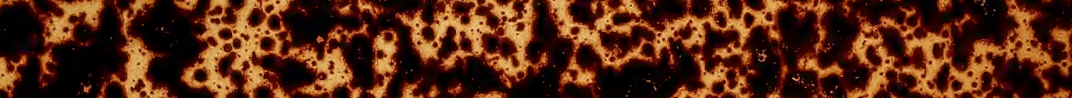
(6.

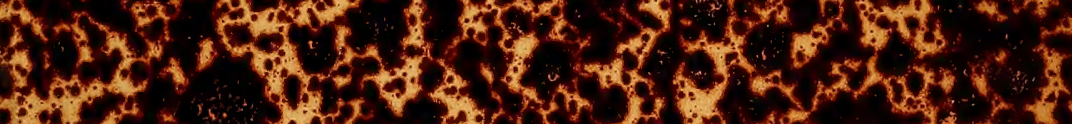

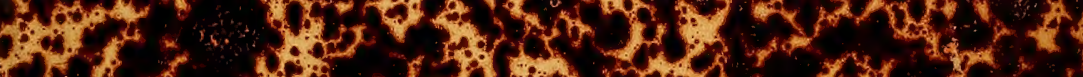

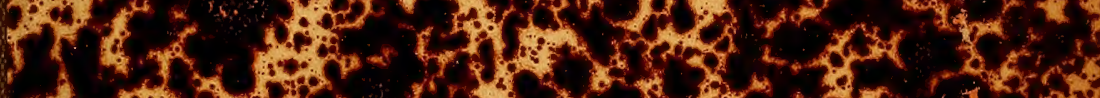

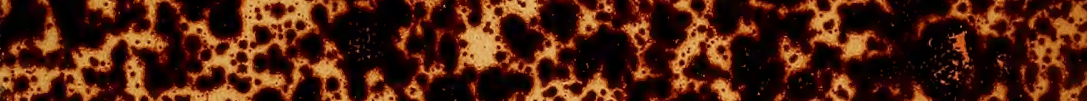

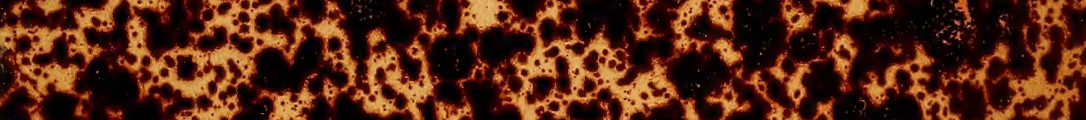

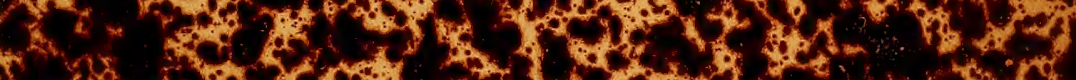

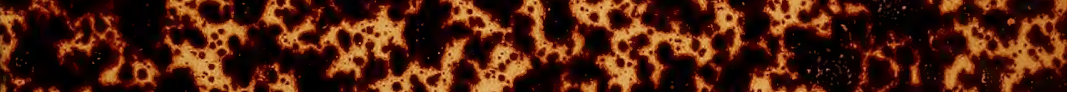

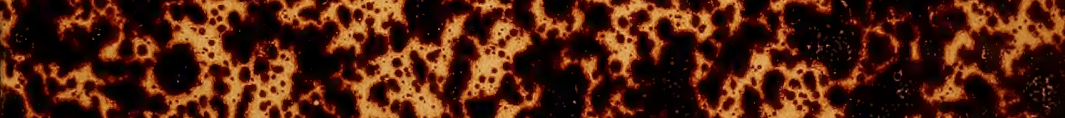

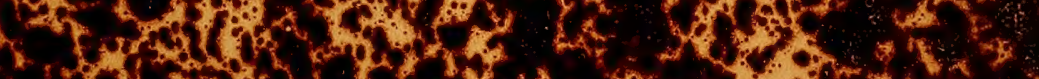
4 -

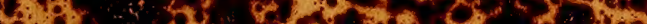




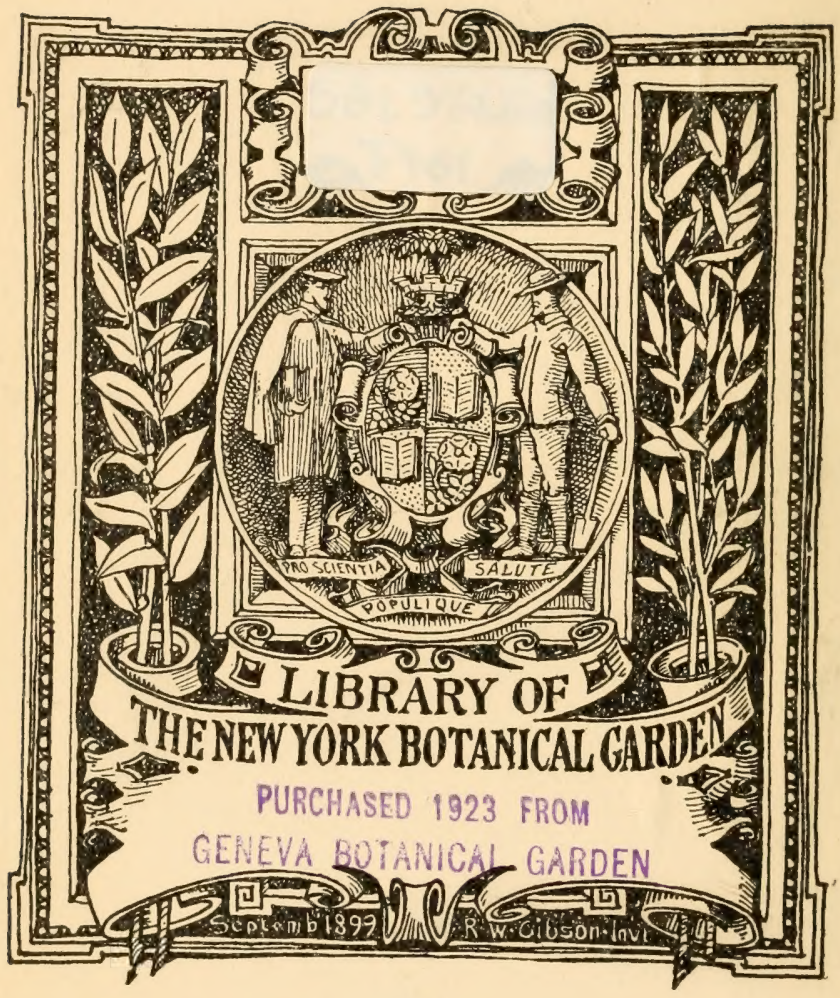






\title{
CATALOGUE OF PLANTS
}

\author{
FOUND IN
}

ONEIDA COUNTY AND VICINITY.

BY JOHN A. PAINE, JR. 
Livres donnés en 1912 à la Bibliothèque du Conservatoire botanique de Genève par M. William Barbey.

$$
\text { DUPLICA }{ }^{m} \text { : DF LA BIBLIOTHEิQUE }
$$

DU CONSERV $A^{\circ}$ TE BCTANIQUE DE GENEVE VENDU EN 1922 
From the Report of the Regents of the University of the State of New-York, presented March 22, 1865.

\section{CA'TALOGUE OF PLANTS}

FOUND IN

ONEIDA COUNTY AND VICINITY.

Br JOHN A. PAINE, JR.

\section{NEW YOLK}

BUTANICAK

UAKUEN

\section{NOTE.}

THIs Catalogue is designed to be a record of the observations of botanists who have resided in the central part of the State. Many names are given fully; others, of the most active, of necessity are abbreviated and-without titles, but are well known in this branch of science :- Prof. CHESTER DEW E.Y D.D., Ju.D.. of Rochester; Prof. James Hadley, M.D., of Buffalo; Péter D. Kayieskern, M.D., of Shark-river N.J.; Henry P. Sartwell, M.D., Ph.D., of Penn-Yan; Samuer B. Bradley. M.D., of West-Greece; Ithamar B. Crawe, M.D., formerly of Watertown; Professor Asa Grax, M.D., LL.D., of Cambridge, Mass.; Hon. George W. Chinton, LL.D., of Buffalo; Professor Jonathan Pearson, of Schenectady; William A. Wood, M.D.. formerly of Dexter; GEORGE VASEx, M.D., of Ringwood, III.

When names are given, they are authority for all localities of the sentence in which they stand, but extend to no other sentence either preceding or following. When no name is given, the reference is founded on observation by the writer.

UTicA, December, 1864.

PH ANOGAMIA.

I. DICOTYLEDON Æ.

1. ANGIOSPERM E.
Flowering Plants.

Dicotyledons.

Angiosperms.

\section{A. POLYPETALOUS EXOGENS.}

RANUNCULACE $\mathrm{E}$.

Crowfoots.

\section{AMERICANA, Sims.}

American Atragene.

Shady rocks, woods and hillsides. Helderberg mountains, Pearson. Otsega county, B.D. Gilbert. Littlefalls, Herkimer county, south side of the Mohawk, along the cliff. Yates county, Sartwell. 
CLEMATIS, $L$.

Virgin's Bower. Traveller's Joy.

VIRGINIANA, $L$.

Virginian Clematis.

Open woods occasionally, often along fences, walls; common on the banks of streams.

July - September.

ANEMONE, $L$.

MULTIFIDA, $D C$.

Anemone. Wind-flower.

Many-parted-leaved Anemone.

On limestone rocks along the Black river at Watertown. Crawe, Gray in Rare plants of Northern N.Y. On the rocky banks of the river at Watertown, just by the bridge of the Brownville road, Gray. Along the river-cliffs between Brownville and Dexter. Vasey. To be looked for on the Thousand Islands of the St. Lawrence, Gray.

Rare. June.

\section{CYLINDRICA, Gray.}

Cylindrical-headed Anemone.

In dry pine barrens, near Oneida lake. New-York, Gray in Rare plants of Northern N.Y. Pine plains, one mile north of New-London; abundantly a few miles above Watertown, Knieskern. Along the north side of the Biack river, between Watertown and Dexter. Rare. May, June.

VIRGINIANA, $L$.

High Anemone.

Barren hillsides, along fences, in ravines.

PENNSYLVANICA, $L$.

Abundant. June - August. the lakes.

Round-headed Anemone.

NEMOROSA, $L$.

Abundant, June, July.

Rich shady woods. Sehenectady, Pearson. Holland Patent, Miss J. E.Johnson. Deerfield. Frankfort hill, J.G.Crocker. Fish ereek. Infrequent. May.

HEPATICA, Dillenius.

TRILOBA, Chaix.

Shady woods and ravines.

ACUTILOBA, $D C$.

Rich woods.
Hepatica. Liver-leaf. Three-lobed-leaved Hepatica.

Frequent.

Acute-leaved Hepatica.

Common. March. April.

\section{THALICTRUM, Tourn.}

Rue.

ANEMONOIDES, Michx.

Rue Anemone.

Open woods. Albany, herb. Bradley. Schenectady, Pearson. Common in a few localities near New-London, Knieskern. Uncommon. April-June.

DIOICUM, $L$.

Rocky banks and sides of ravines.
Early Rue. Dixcious Rue.

Frequent. April, May. CORNUT, $L$.

Meadow Rue. Discovered by CoRnutr.

Wet meadows, low grounds and rich woods. Common. June-August.

\section{RANUNCULUS, $L$.}

AQUATILIS, L., var. DIVARICATUS, Gray.

Crowfoots. Buttercups.

Water Crowfoot.

Cold streams. Schenectady, Pearson. Abundant in the raceway at Oriskany.

Two miles east of Rome, along the railroad, in a spring-brook. Fish creek, Vienna, Knieskern. Gorham, sartwell. Infrequent. June-August.

PUrshil, Richards. Floating Buttercup. Determined by Pursh. Still water, bogs, in mud along rivulets.

" Ноoкек, Fl. Bor. Am. a. foliis omnibus capillaceo-multifidis, flore majore, caule fistuloso. In stagnant water, throughout the western and northern portions of the State :

ß. foliis submersis capillaceo-multifidis, natantibus reniformibus palmatomultifidis. In muddy pools near Oneida lake : 
$\gamma$. repens, foliis inferioribus lineari-multipartitis, superioribus reniformibus palmato-multifidis. In marshes, Watertown, Jefferson county:" Gray in Rare plants of Northern N.Y.

Braudy brook, three miles north of Verona, Knieskern. Seneea lake. Sartweil.

Scarce. May - July.

ALISMmatids, Geyer.

Water-Plantain-leaved Cros-foot. Greater Spearwort.

Overflowed banks. Western counties. Knieskern in herb. Vasey Crooked lake, Sartwell.

Rare. June - August.

FLAMMULA, $L$.

Flame Crowfoot. Lesser Spearwort.

Shore of Lake Ontario, Gray bot. Lake Erie, Gray in herb. Hant. Coll.

Rare. June - August.

var. REPTANs, Gray.

Creeping Spearwort.

Sandy shores. At the water-line along the shores of the Eight lakes, north Herkimer eounty. Shore of Lake Ontario, Vasey. Sackett's-harbor; mouth of Oneida creek on the Lake shore; Chenango county, Kneskern. Marshy edge of Owaseo lake outlet, I. H. Hall. Uncommon. July-September.

cymbalaria, Pursh.

Seaside, Cymbal-leaved Crowfoot.

Salt-marshes and shores. On the borders of Onondaga lake, about the head at Salina and along the eastern sides. Abundant there: the only habitat given by Pursh. A very singular plant, first detected by PuRsh near the salt-works of Onondaga, New-York, Hooker.

Local. June - September.

ABortivus, $L$.

Damp woods, wet places.

SCELERATUS, $L$.
Abortive Buttercup. Common. May, June.

Noxious Buttercup. ome. Salina.

Infrequent. May - July.

ReCURvatus, Poiret.

Shady wet woods.

PENNSYLVANICUS, $L$.

Brook-sides, ditches.

FASCICULARIS, Muhl. Sartwell in herb. Ham. Coll.

REPENS, $L$.

Not common. April - June.

Overflowed places, along ditches, brooks, rivers. Common. May-August.

Clintonit, Beck.

Dedicated to G. W. Clinton.

"Leaves ternate, 3-cleft, hairy. hairs close-pressed; extreme upper leaflets lanceolate : stem entirely prostrate, creeping, zigzag : petals obovate, subretuse : calyx caducous; seed compressed, margined: beak hooked. Flowers large, resembling those of the repens. In Oneida county, between Rome and Oriskany, near the Erie canal, patches of ground, several yards in extent, are often covered with this species. The flowers are rarely elevated more than 8 or 10 inches above the ground, though the stem creeps more than a yard from the root. I discovered this plant in the summer of 1824." Eaton bot.

"Somewhat hairy; stems ereeping and rooting at each of the joints; lower leaves on long petioles, ternate; leaflets toothed and incised, cuneate, terminal one petioled; floral leaves incised or linear; peduncle $1-3$-flowered; petals rounded; calyx spreading; carpels margined, with a short uncinate style. Banks of the canal, near Rome, Oneida county, N.Y. Much smaller than $R$. repens, in all its parts except the flower, which is of a bright yellow and about as large as that of $R$. acris. Leaves seldom more than $1 \frac{1}{2}$ inches in length, and about the same in breadth. Stems distinctly creeping like those of $R$. reptans : flowering ones $6-8$ inches high. Style short and hooked." Beck bot. 
The peculiar habit of the plant carpeting the ground in patches, its prostrate flowering stems, the low flowers, beaked fruit, small thick dark green leaves, distinguish the species. Local. May - July.

BULBOSUS, L.

Bulbous Buttercup.

Roadsides, pastures, borders of woods. Schenectady county, abundant on the hillsides south of the Mohawk. Chenango county. Searce. May - July.

ACRIS, L.

Way-sides, meadows, everywhere.

CALTHA, $L$.

PALUSTRIS, $L$.

Wet meadows and swamps.

TROLLIUS, $L$.

LAxUs, Salisbury.
Yellow-weed. Acrid Buttercup.

Common. June - November.

Frequent in arbor-vitæ swamps on the south range of hills, from Summit lake, Otsego county, through the cedar swamps of south Herkimer county. Bridgewater and along the Oriskany creek, below Clinton, Gray. Three miles west of Utica, near the Chenango canal, in abundance.

In exposed places, the American is not inferior in size or beauty to the European Globe-flower. It stands from two to three feet high, has dark green leaves, and bears flowers frequently two and a half inches in diameter, which. in the sun, are deep golden yellow, veined above and tinged beneath with green. A few flowers are sent up in autumn, but are ent down by the first frost; yet perfectly formed flowers and leaves lie near the surface of the ground during winter, enclosed in radical sheaths. In early spring, these appear and expand fully at the height of two or three inclies. Later, the plants crowd in hemispherical clusters, which are covered with flowers : at this height, twelve to fifteen inches, these are largest and most beautiful. Others rise, until the last and highest about the middle of May, so that the plant is in bloom during a month or more.

April, May.

COPTIS, Salisbury.

Trifolia, Salisb.

Moist woods under evergreens.

AQUILEGIA, Tourn.

CANADENSIS, $L$.
Goldthread.

Three-leaved Coptis.

Abundant. May, June.

Columbine.

American Columbine.

Clefts of rocks, rocky hillsides, and even in sandy soil.

Common. April - Oetober.

ACONITUM, Tourn.

Aconite. Monkshood.

UNCINATUM, $L$.

Hook-helmeted Monkshood.

In wet places on mountains. Chenango county, Major J. LeConte, Torrey Cat. and Fl. N.Y.

Local. July, August.

ZANTHORHIZA, Marshall.

APIIFOLIA, L'Héritier.

Shrub Yellow-root.

In a deep ravine, Sherburne, eleven miles south of Hamilton, J.S.Douglass, Torrey Fl. N.Y., Gray bot. Cultivated by Prof. O. Roox, in a ravine on College Hill, Clinton, where it flourishes : remains long in flower.

April - June.

HYDRASTIS, $L$.

Herb Yellow-root.

CANADENSIS, $L$.

Orange-root.

Moist woods and wet meadows. Clinton, Dr. Seth Hastings. Oneida county and vicinity; Greece, Bradley. Yates county, rare, Sartwell. Abundant in open woods in Niagara county, Knieskern.

Rare. April, May. 
只TA, $L$.

SPICATA, $L$ 。

var. RUBRA, Michaux.

Ravines, borders of thickets.

var. ALBA, Michaux.

Flats of streams, moist open woods.

Baneberries.

Spicate Actra.

Red Baneberry.

Frequent. May.

White Baneberry.

Abundant. May.

Snakeroat.

CIMICIFUGA, $L$.

RACEMOSA, Ellioti.

Black-rooted, Racemed Cimicifuga.

Rich woods, rocky shaded hillsides. Helderberg mountains, Pearson. Abun-

dant along the Chenango valley, espeeially near Binghamton, on dry gravelly hills, Knieskern. Rocky banks of Seneea lake, near Starkey, Yates county, Vasey. Greece, on the banks of Genesee river, Bradley.

Frequent. July, August.

\section{MAGNOLIACE $A$.}

MAGNOLIA, $L_{\text {。 }}$ ACUMINATA, $L$.
- Magnolias.

Magnolia.

Fertile soill. Near Ithaca, Knieskern, Vasey. Dundee, Yates county, Wright in herb.Vasey. Penn-Yan, Surtwell. Open woods in Niagara eounty, Knieskern.

Rare. June.

IIRIODENDRON, $L$.

TULIPIFERA, $L$.

Whitewood. Tulip-tree. Tulip-bearing Liriodendron.

Sunny hillsides, rich woods. Seheneetady, Pearson. Littlefalls, south side of the Mohawk; Whitesborough; Oriskany; frequent about Oneida lake; Onendaga county. About Auburu, I. H. Hall. Broome county, H. Lathrop. Infrequent. June.

\section{ANONACE $\mathrm{E}$.}

ASIMINA, Adanson.

TRILOBA, Dunal.

\section{Custard-apples.}

North-American Papaw. Three-lobed-calyxed Asimina.

Rich banks. Greeee and Parma, Monroe county, Bradley. Shore of Lake Erie, near Bareelona, Chautauqua county, Knieskern. Rare. April, May.

MENISPERMACE E。

Moonseeds.

MENISPERMUM, $L$ 。

CANADENSE, $L$.

Moonseed.

Canadian Menispermum.

Woods, thickets, especially along streams. Abundant in the valley of the Mohawk.

Frequent. June.

\section{BERBERIDACE $\mathrm{E}$}

Berberids.

BERBERIS, $L$.

FULGARIS, L.

Barberry.

Common Berberis,

Naturalized sparingly by roads, hedges, borders of woods. New-Hartford. May.

CAULOPHYLLUM, Michaux. thalictroides, Mich $x$.

Woods, fences, ravine bottoms.

[ON. PL.]
Blue Cohosh. Pappoose-root. Rue-like Caulophyllum. Abundant: April, May: 
JEFFERSONIA, Barton.

Jeffersonia.

Diphylla, Persoon.

Twin-leaf.

Rich woods, limestone rocks. About three miles west of Dexter, Jefferson county, Vasey. Near Geneva, Sartwell in herb. Ham.Coll. Rare. April.

PODOPHYLLUM, $L$.

PELTATUM, $L$.

Mandrake. May-apple.

Fences, meadows, borders of woods, flats of streams. Abundant. May.

NELUMBIACE E.

Sacred Bean.

NELUMBIUM, Jussieu.

LUTEUM, Willd.

Nelumbo. Lotus.

Yellow Nelumbium.

Lake Ontario, Big Sodus bay, Wayne county, near the road just north of the bridge, Surtwell.

Local. June, July.

\section{CABOMBACE $\mathrm{A}$.}

Water-shields.

BRASENIA, Schreber.

Peltata, Pursh.

Water-target.

Peltate Brasenia.

Still water, ponds, lakes. Abundant in the lakes of the north woods. Stagnant ponds in Verona, Knieskern. Mill-pond two miles northwest of NewLondon. Lebanon, Madison county, Bradley. Schuyler's lake, Otsego county, G.W.Clintan. Crooked lake, Sartwell. Rare. June - September.

\section{NYMPHAACE E。}

Water-lilies.

NYMPH EA, Tourn.

odorata, Aiton.

Water-nymph. Fragrant Water-lily.

Slow streams, ponds, borders of lakes; sometimes in mud, with erect leaves and flowers. Common in the lakes of the north woods; Oneida lake; Oneida creek; Cedar lake and Hidden lake, south Herkimer county. Otsego county, H. Lathrop.

The variety with rose-colored flowers, in Raquette lake, north IIamilton county.

The variety with inodorous flowers, in an inlet of Lake Ontario, a mile or two north of Oswego : plant very large in all its parts; flowers, six or seven inches in diameter; leaves, eight to ten. Not common. June - September.

NUPHAR, Smith.

ADVEna, Aiton.

Ponds, pools, ditches.

ralitana, Pursh.

Yellow Pond-lily. Spatterdock. Stranger (to the old world) Nuphar.

Very common. May - August. Tranquil water. Sanders's lake, Glenville, Pearson. Mouth of Oneida creek, Knieskern. Abundant in Black brook, near Oneida lake. Flint creck, Yates county, Sartwell. Rare. May - July.

\section{SARRACENIACEAE.}

\section{SARRACENIA, Tourn.}

PURPUREA, $L$.

\section{Water-pitchers. \\ Huntsman's-cup. Pitcher-plant. Purple-flowered Sarracenia.}

Swamps, especially in sphagnum. Abundant in the north woods. Schenectady, on the Pine plains, Pearson. Paris hill; Graefenberg hill. Oriskany swamp, Vasey. About Oneida lake.

HETEROPHYLLA, Eaton.

Frequent. June, July.

Varying-leaved Sarracenia.

Flowers greenish yellow; leaves variable, green, veinless. Sphagnous swamp. Junius, Seneca county, Sartwell.
Local. June. 
PAPAVERACE A.

Poppies.

CHELIDONIUM, $L$.

$M A J U S, \mathrm{~L}$.

About houses, walls, waysides.

Celandine.

Great Chelidonium.

Common. May-September.

SANGUINARIA, Dillenius.

Bloodroot.

CANADENSIs, $L$.

Along fences, open woods, sides of ravines.

Canadian Sanguinaria.

Abundant. May.

FUMARIACE E.

Fumitories.

ADUUMIA, Rafinesque.

Cirrhosa, $R a f$.

Alleghany-rine Tendrilled Adlumia.

Moist shady places in rich woods. Helderberg mountains, Pearson. About Otsego lake, Miss S. Cooper: H. Lathrop: B.D.Gilbert. Junius, Sartwell in herb. Ham. Coll. Greece, Parma, Bradley. Rare. June-September.

DICENTRA, Borkhausen.

Dicentras.

cucullaria, DC. Dutchman's Breeches. Hooded-spurred Dicentra.

Moist rich soil.

Common. April, May.

CANADENSIS, $D C$.

Squirrel-corn.

Shady woods, ravine-sides.

Abundant. March - May.

EXIMIA, $D C$.

Purple, Choice Dicentra.

Rocky woods. Wayne county, not far from Sodus bay, sartwell.

Local. May - August.

CORYDALTS, Vent.

AUREA, Willd.

Corydalis.

Golden Corydalis.

Among shaded rocks. Along the north side of Black river, between Watertown and Brownville. Rich soil near Oriskany, Knieskern.

Rare. May - July.

glatua, Pursh.

Glaucous Corydalis.

Rocks. Littlefalls, south side of the Mohawk; Bald-rock, north Herkimer county. Recently burnt-over ground near Orỉskany, Knieskern.

Frequent. May - August.

FUMARIA, $L$ 。

OF F ICIN ALIS, L.

A weed in gardens and cultivated grounds.

Frequent. Flowers throughout the season.

\section{CRUCIFER AE.}

NASTURTIUM, $R$. Brown.

OF FICIN ALE, R. Br. Cold streams. Springy hillside at the head of the raceway, Oriskany. Jacob's brook, Yates county, Sartwell.

Palustre, $D C$.

Scarce. May - July.

Cresses. Nasturtia. European, Officinal Watercress.

Overflowed places, ditches, muddy shores. Common. The typical form, Yates county, Sartwell.

HISPIDUM, $D C$.

June - August.

Inundated banks of rivers. Along the Mohawk, Penn-Yan, Sartwell.

Infrequent. June - August, 
LACUSTRE, Gray.

Lake Cress.

Muddy banks, streams, lakes. In the St.Lawrence river near Ogdensburgh, Crawe. Gray in Rare plants of Northern $N . Y$. Jefferson county, Crawe in herb. Ham. Coll. Oneida lake, where it is very abundant in water two to five feet deep, Gray. Along the shore of Oneida creek near its mouth, growing: erect twelve to eighteen inches.

Rare. June - August.

ARMORACI.A, Fries. Horscradish. Water-side Nusturlium.

Waste places, walls, along water-courses. Frequent on the banks of the

Mohawk. Extensively naturalized. May - July.

DENTARIA, $L$.

DIPHYLLA, $L$.

Moist woods.

MAXтMA, Nuttall. town, N.Y., Crawe, Gray bot. Abundant in the raviue of Deerfield creek, north of Utica, in deep moist soil. Among the headwaters of this ereek on the hills, aloug wooded rivulets, the flowers are purple and racenes elongated. Leaves three, alternate, distant: root deeply interrupted. Rarely from the axil of the highest leaf a smaller secondary stem springs, having two leaves: and a raceme. Rich bottoms of Starch-factory creek, east of Utiea : the true form. On the west side, along the border of the gulf, in moist places, of form: occurs between this species and $D$. diphylla; having denticulate rootstalks, three alternate remote leaves and white flowers. Both forms usually send up a radieal leaf, beside the stem.

Rare. Early in May.

IACINIATA, Muhl.

Rich shady woods.

HETEROPHYLLA, Nuttall.
Necklace Pepper-root. Cut-leared Dentaria. Frequent, April.

Variable-leaved Dentaria.

Deep woods. Near Watertown, Jefferson county, Knieskern. Along bottoms of gulf-sides in Deerfield creek, and woodland ravines on the hills. Leaves. two, sometimes four, alternate, remote, deeply divided into narrow lobes, slightly toothed. Root moniliform, frailly connected.

Rare. May.

CARDAMINE, $L$ 。

RHOMBOIDEA, $D C$.

Wet meadows and miry places in woods.

Var. PERPUREA, Torr.

Low grounds along shaded streams.
Spring Cresses. Rhomblike-leaved Cardamine. Abundant. May, June. Purple-flowered Cardamine. Frequent. April, May.

PRATENSIS, $L$.

Cuckoo-flower. Meadow Cardamine.

Swamps in the western part of the State, particularly in Oneida county, Torr. $F l, N . Y$. Wet meadows and bogs on the flats of the Mohawk. Oriskany swamp, Vasey. Plenty on Hidden lake, Litchfield, Herkimer county. Seneca and Gorlam, Ontario county, Sartwell. Rare. April - June.

HIRSTTA, $L$.

Rocks, hillsides, springs, ditches brooks, swamps, muddy places in woods. Very common. Throughout the season.
ARABIS, $I$ 。

LYRATA, $L$.

Clefts of rock

kern.

DENTATA, Torr. $\&$ Gr.

Banks of streams. Near Utica, Gray, Torr. Fl. N.Y.
Wall-cresses. Rock-cresses.

Lyrate-root-leaved Rock-cress.

Abundant on the cliffs at Littlefalls. Trenton falls, KniesFrequent. April-Oetober.

Dentate-leaved Rock-cress. Rare. May. 
HIRSUTA, Scopoli.

Hairy Rock-cress.

Rocky banks. Helderberg mountains, Pearson. Trenton falls, Knieskern. Watertown, N.Y., Gray in herb. Ham. Coll. Along the Black river below Watertown. Bluff point, Yates county, Sartwell. Rare. May, June.

L 㷉伯ATA, $D C$.

Smooth Rock-cress.

Shaded rocks, thickets along water-courses. Schenectady, Pearson. Cliffs and steeps at Spraker's, Montgomery county; Little falls of the Mohawk; Trenton falls; banks of $F$ ish creek, near the crossing of the Oswego county turnpike. Vienna, Knieskern.

Frequent. May - July.

CANADENSIS, $L$.

Sickle-pod.

Rocks, wooded hillsides. Rocks along the College brook, Schenectady, Pearson. Southern tier of counties from Binghamton westward, on dry gravelly hillsides, rare, Knieskern. Yates county, Sartwell.

Scarce. June - August.

TURRITIS, Dillenius.

Tower Mustard.

GLABRA, $L$.

Smooth Tower-mustard.

Rocky banks, woods, fields. Watertown, N.Y., Torrey \& Gray; Knieskern in herb. Ham. Coll. Along the north bank of Black river between Watertown and Brownville, among rocks. Dexter, N.Y., Wood in herb.Ham.Coll.

Scarce. May, June.

STRICTA, Graham.

Straight-podded Tower-mustard.

Wooded banks of streams. Dexter, N.Y., Wood in herb. Ham. Coll. Watertown, Jefferson county, where it was first found by Crawe. Lebanon, Chenango county, J.S. Douglass, Torrey Fl.N.Y. Along Fish creek near Humaston's, Rome, Vasey.

Rare. May.

BARBAREA, $R$. Brown.

Winter Cress.

VULGARIS, $R, B r$.

Yellow Rocket. Common Winter-cress.

Wet grounds, roadsides, ditches, woods. A common weed. All the season.

ERYSIMUM, $L$.

CHEIRANTHOIDES, $L$.

Treacle Mustard.

Moist ground, along streams, clefts of rocks. Sparingly in Oriskany along the creek, Vasey. Mohawk flats. Rocks at Chittenango falls. Penn-Yan, Sartwell.

Abundant. June - September.

SISYMBRIUM, $L$.

OF FICIN ALE, Scopoli.

Waste places.

SINAPIS, Tourn:

ARVEN SIS, L.

Waste places, roadsides, cultivated fields.

NIGRA, L.

About gardens and cultivated grounds.

DRABA, $L$.

arabisans, Michx.

Ledges, rocks, river-banks. Borders of small lakes in the northern part of the State, Torrey \& Gray. St.Lawrence county, Gray in herb. Ham. Coll. Crevices of rocks at the mouth of Black river, Vasey. Sackett's-harbor, Knieskern in herb. Ham. Coll.

VERNA, $\boldsymbol{L}$.

Whitlow-grass. Early Draba.

Rocks, hillsides, old fields. Received from Jefferson county, Sartwell. Hackney falls, near Auburn, I. H. Hall.
Rare. May - June.

Hedge Mustard.

Officinal Hedge-mustard.

True Mustard. Charlock. Wild Mustard. Common. June-August.

Black Mustard.

Common. May - August.

Whitlow-grass. Arabis-like Draba.

Rare. March - May. 
CAMELINA, Craniz.

S.ATIV. Crantz.

Along railroads. In flax, Knieskern. Penn-Yan, frequent, Sartwell.

May - July.

T.EPIDIUM, $L$.

VIRGINICUM, $L$.

Streets, railloads.

CAPSELLA, Vent.

BURS.A-PASTORIS, Mœnch.

Everywhere common.

THLASPI, Dillenius.

ARVENSE, L.

Stony fields, State of New-York s rare v. v Pursh. Yaturalized in St.

Lawrence county.

RAPHANUS, $L$.

R.APH.ANIST RUM, D.

Waste places on the banks of the Mohawk.

CAPPARIDACE A.

POLANISIA, Rafinesque.

GRAVEOLENS, Raf. lake near Constantia, Vasey. Cayuga bridge, Bradley. Beach of Croỏhed lake, Sartwell.

RESEDACEA.

RESEDA, $L$.

LUTEOLA, L.

White Charlock. Wild Radish.

Jointed-podded Raphanus.

Scarce. June, July.

Capers.

Polanisia.

Heavy-scented Polanisia.

Scarce. June - August.

Roadsides in Western New-York, Gray bot. Fairfield? Herkimer county, in herb. Hadley. Rare. June - August.

\section{VTOLACE AE.}

SOLEA, Ging.

CONCOLOR, Ging.

Mignonetts.

Mignonette.

Shady woods. Near a small pond one mile east of Utica, in company with

Fedia fagopyrum; near Vernon, J.S.Douglass, Knieskern. Near Penn-Yan, Sartwell.

Rare. May. I

VIOLA, $L$.

Violets.

ROTUNDIFOLIA, Michaux.

Round-leaved Violet.

Rich woods, sides of ravines, shade of evergreens. Abundant. March-May.

LANCEOLATA, $L$.

Lance-leaved Violet.

Marshes, shores of streams. Albany, Beck bot. Schenectady, half a mile east of Coon Chisholm's, Pearson. Clinton, Bradley. Rare. May, June.

PRIMULAFOLIA, $L$.

Wet meadows.

BLANDA, Willd.

Wet woods, low grounds, along rivulets.
Primrose-leaved Violet. Infrequent. April - June.

Pretty Violet.

Common. April - June. 
SELKIRKII, Goldie.

SELKIRK's Violet.

Clayey hillsides, open woodlands, pastures, about stumps and old logs, under young evergreens, and in deep mossy ravines. Abundant.

Oneida county appears to be one of the favorite abodes of this rare species. It is as beautiful as $V$. blanda, and more interesting. In color, it is usually deep blue, sometimes purple. In form, the flowers are like those of $V$. pedata, with a long spur, and the leaves like those of $\boldsymbol{V}$. blanda crenulated. It prefers the north side of hills; and sometimes occurs exceedingly minute, an inch high, leaves half as broad and smaller. The flowers are almost ephemeral; they can be found only during four or five days in April.

\section{cuCUllata, Aiton.}

Hooded-leaved Violet.

Waysides, wet meadows and woods. Common.

Flowers with stripes of purple and white, along the rocky steep at Spraker's, Montgomery county.

Flowers pure white, up the ravine of Deerfield creek, and along brooks on the Litchfield hills. May - July.

var. PALMATA, Gray.

Hand-leaved Violet.

Swamps. Along Tan-house creek, Schenectady, Pearsan. Near Oriskany, Knieskern. Crooked lake outlet, Sartwell. Rare. May - June.

sagittata, Aiton.

Arrow-leaved Violet. Dry hillsides, copses, pastures. Plains of Rome. Frequent. April, May.

\section{PEDATA, $L$.}

Foot-leaved Violet.

Gravelly woods, sandy plains. On the Pine plains near the Gunsaul road, Schenectady, Pearson.

Rare. May - September.

rostrata, Pursh.

Moist woods, rich flats along streams.

\section{MUHLENBERGII, Torrey.}

Ravines and swamps.

STRIATA, Aiton.
Beaked-spurred Violet. Abundant. May, June.

Determined by MUHLENBERG. Common. April - June.

Veined-flowered Violet.

Rich open woods. Banks of the Mohawk opposite Whitesboro Seminary. Oriskany, Vasey. Clark's mills. Clinton; Franklin, Miss L. W. Shattuck.

Rare. April - September.

\section{CANADENSIS, $L$.}

\section{Canadian Violet.}

Groves and moist shady hillsides. Abundant. Completely covering the ground in many woods. Flowers throughout the season.

pubescens, Aiton.

Open woods, ravines, pastures.

var. ERIOCARPA, Nuttall.

Dry woodlands.

var. SCABRIUSCULA, Torr. \& Gr.
Downy Yellow Violet.

Common. April - June.

Woolly-fruited Violet.

Frequent. May.

Rough-leaved Violet.

Copses. Albany, Beck bot. Oneida county, Knieskern.

Infrequent. May, June.

CISTACE $\AA$.

Rock-roses.

HELIANTHEMUM, Tourn.

CANADENSE, Mich $x$.

Sun-roses.

Frost-plant.

Rocks, sand. Everywhere in Schenectady, Pearson. Dry sandy plains near

Oneida lake, Knieskern. Common on our sandy knolls, Sartwell.

Infrequent. June - August. 
LECHEA, $L$.

Lecheas.

MAJOR, Michaux.

Greater Lechea.

Sterile soil. Pine plains, Schenectady, Pearson. Yates county; Avon, Sartwell in herb. Ham. Coll.

Rare. July.

MINOR, Lamarck.

Pinweed. Lesser Lechea.

Dry fields and pastures.

Common. June - August.

DROSERACEAE.

Sundews.

DROSERA, $L$.

Sundews.

ROTUNDIFOLIA, $L$.

Round-leaved Sundew.

Around springs, wet bogs, sphagnum swamps. Frequent. July, August.

LONGIFOLIA, $L$.

Spatulate-leaved Sundew.

Sphagnous bogs. Borders of cold ponds near the chain of Eight lakes, north Herkimer county; doubtless abundant throughout the north woods. Near Dexter, Jefferson county, Vasey. Cedar swamp, Gorham. Sartwell.

Rare. June, July.

PARNASSIACE A.

Parnassias.

PARNASSIA, Tourn.

Caroliniana, Michx.

Grass of Parnassus.

Carolinian Parnassia.

Springy banks and along streams. In the spray from the IIigh falls, Trenton falls; below the falls, near the lower dam, abundant. Wet eliffs on the east branch of Fish creek, at Fall brook, abundant there; along the banks of the creek below Taberg station. Infrequent. August, September.

\section{HYPERICACE $Æ$.}

St.John's-worts.

HYPERICUM, $L$ 。

Hyperica.

PYRAMTdATU, Aiton.

Pyramidal-flowered Hypericum.

River bottoms. Frequent in the valley of the Mohawk. Schenectady, Pearson. Littlefalls, Vasey. Two miles above Utica, on the north bank of the river. Near Flint-hill, between the canal and the Mohawk; along Fish creek near Taberg, Knieskern. Rare. July, August.

PERFORATUM, L.

Roadsides, fields, pastures.

CORYMBOsUM, Muhl.

Borders of woods, swamps.

ELLIPTICUM, Hooker.

Perforated Hypericum. Everywhere common. June - September.

Corymbed Hypericum.

Frequent. June - August.

Elliptical-leaved Hypericum.

Low grounds, wet shady banks of streams and lakes in the northern part of Herkimer county.

Infrequent. July, August.

MUTILUM, $L$.

Wet ground.

CANADENSE, $L$.
Diminutive-flowered Hypericum.

Common. July - September.

Along streams, swamps. Trenton falls. North woods.

Uncommon. June - September.

ELODEA, Pursh.

Marsh St.John's-wort.

VIRGINICA, Nuttall. Purple Elodea.

Along brooks, swamps sphagnum.

Common. July-September. 
ELATINACE E.

Water-worts.

EI,ATINE, $L$.

Water-wort.

aMericana, Arnott.

Muddy banks of streams. Albany, Beck.

American Water-wort. Rare. July - September.

CARYOPHYLLACE 屟。

Pinks.

SAPONARIA, $L$.

Soap-wort.

OFFICINALIS, L.

Dooryards, roadsides, ${ }^{\top}$ railroads.

Officinal Saponaria.

Common. July - October.

SILENE, $L$.

Catckfly. Campion. steldata, Aiton.

Starry Campion. Stellate-leaved Silene.

Wooded hillsides. Near Sleepy-hollow. Tarrytown; and abundantly on the mountain-side above Nyack, I. H.Hall. Near Oriskany, Knieskern. Frequent on the banks of Crooked lake, Surtwell. Rare. July-September.

INF LATA, Smith.

Bladder Campion. Inflated-calyxed Silene.

Dry gravelly soil. Verona, not common, Knieskern. Rare. July, August.

PENNSYluanicA, Michx.

Wild Pink.

Rocky soil. Cliffs near Tarrytown, I. H. Hall. Amenia, Dutchess county, Dow. Schenectady, Pearson.

Rare. May - July.

VIRGINICA, L.

Fire Pink。

Open woods. Yates county, Sartwell.

Rare. June, July.

ARMERIA, L.

Sweet-william Catchfly.

Escapes occasionally, sometimes troublesone, D. S. Heffron.

July - September.

ANTIRRHINA, $L$.

Snapdragon Catchfly.

Roadsides, barren soil. Banks of Black river. Frequent. June-September. NOCTIFLORA, L.

Night-flowering Catchfly.

Borders of woods, fenees, eultivated fields. Common. June-September.

LYCHNIS, Tourn.

Diceious Pink.

VESPERTINA, Sibthorpe. White Campion. Evening-opening Lychnis.

Hedges, waste places. Elmira, Chemung county, Gray add. bot.

Rare. June - September.

AGROSTEMMA, $I$.

GITHAGO, L.

Grain-fields and their borders.

Cockle. Crown of the Field.

Black-seeded Agrostemma.

Common. June, July.

ALSINE, Wahl.

MichadXix, Fenzl.

Grove Sandwort.

Discovered by Michaux.

Dry rocky hills and banks. Thousand Islands of the St.Lawrence. Abundant along the Black river, from Lewis county to the lake. On sandy knolls two miles above Utica, on the north side of the Mohawk, Miss J. E. Johnson.

Rare. May - July.

ARENARIA, $L$.

Sandwort.

SERPYLLIFOLIA, L.

Thyme-leaved Sandwort.

Rocky banks, barren soil. ledges, sandy plains. Abundant. May-August.

[ON. PL.] 
MIEHRINGIA, $L$.

Mohringia.

L ATERIFLORA, $L$ 。

Side-flowering Mohringia.

Along rivulets, shady wet woods. Schenectady, Pearson. Near Sackett'sharbor, not far from the lake shore; sandy woods near Oneida lake, Knieskern. Along the Black river and on the banks of the Mohawk, a very small form occurs in exposed stations.

Infrequent. May, June.

STELLARIA, $L$.

Starworts.

$M E D I A$, Smith.

Intermediate-leaved Stellaria.

Waste places. A common weed.

LONGIFOLIA, Muhl.

Brook-sides and meadows.

LONGIPEs, Goldie.

April - November.

Long-leaved Stellaria. Common. June - August.

Long-pedicelled Stellaria.

Barren rocky ground near Dexter, Jefferson county, Vasey. Dexter, N.Y., Wood in herb. Ham. Coll.

BOREALIS, Bigelow. Rare. June, July.

Northern Stellaria.

Wet meadows, grassy swamps. Oriskany; Whitestown; Rome.

Infrequent. June - August.

\section{CERASTIUM, $L$.}

VULGATUM, L.

Pastures, stony ground.

VISCOSUM, L.

Meadows, fields, walls.

nUtAns, Rafinesque.

Mouse-ear Chickweed.

Common Chickweed.

May-October.

Clammy Chickweed. April - July.

Nodding-fruited Chickweed.

Cold springs and rivulets. Below Watertown, along the Black river.

Rare. May - July.

ARVENSE, $L$.

Cornfield Chickweed.

Rocky ground, cultivated fields. Helderberg mountains, Pearson.

Infrequent. May - August.

SAGINA, $L$.

PROCUMBENS, $L$.

Wet sandy banks and shores.

Pearlwort.

Procumbent Sagina. Rare. June - August.

SPERGULA, $L$.

Spurrey. ARVENSIS, L.

Grain-field Spergula.

Along railroads, roadsides, fields. Among flax, Knieskern.

Frequent. June-September.

ANYCHIA, Mich $x$.

Forked Chickweed. DICHO'TOMA, Mich $x$.

Dichotomous-stemmed Anychia.

Dry hillsides. Schenectady, Pearson. Pine platus of Rome, Vasey. Frequent in Yates county, Sartwell.

Uncommon. June - August.

SCLERANTHUS, $L$.

Knawel.

ANNUUS, L.

Annual Scleranthus.

Damp sandy or gravelly places. Piue plaius of Schenectady, Pearson. Waste places in Oneida county, Knieskern. Scarce. May - August.

"OLLUGO, L.

Indian Chickweed.

ERTICILLATA, $L$.

Curpet-weed. Whorled-leaved Mollugo.

Roadsides, shores. Sandy shore of Onelda lake. Rare. June-September. 
PORTULACACE Æ.

PORTULACA, Tourn.

$O L E R A C E A, \mathrm{~L}$.

Waste placos; a weed in cultivated grounds.

CLAYTONIA, $L$.

VIRGINICA, $L$.

Rich river bottoms. Along the Mohawk below Utica; abundant opposite

Whitesboro. Fish creek, Knieskern.

caroliniana, Michx.

Everywhere in woods, groves, copses, swamps.

MALVACE $Æ$.

MALVA, $L$.

ROTUNDIFOLIA, L.

Dooryards, streets, waste places.

SYLVESTRIS, L.

Borders of woods and roadsides remote from gardens. Everywhere scattered and abundant.

May - September.

MOSCH.ATA, L.

Musk-scented Mallow.

Way-sides; well established as the former, and often with it. Abundant in many places.

May - August.

ABUTILON, Tourn.

AVICENN.E, Gærtner.

Gardens, roadsides, waste-places.

HIBISCUS, $L$.

MOSCHEUTOS, $L$.

Velvet-leaf. Indian Mallow.

Dedicated to Avicenna.

Frequent. July - September.

the Salt both of salt and of fresh water. Plentifully in the marshes around the Salt lake, Onondaga, New-York, Pursh. Abundant in the marsines along the outlet of Cayuga lake. Around Irondequoit bay, Monroe county, C.M. Booth. Rare. July - Oetober.

\section{TILIACE $\not$.}

Lindens.

TILTA, $L$.

AMERICANA, $L$.

Rich woods. Common.

Linden-trees. Basswood. June, July.

\section{LINACE E.}

LINUM, $L$.

VIRGINIANUM, $L$. E.W. P. Tarrytown in open rocky woods, I. H. Hall. Schenectady county, counties, Knieskern.

Rare. June - August.

USITATISSIMUM, L.

Cultivated, Useful Flax.

Borders of fields, waysides. Abundant all along on the Central railroad. 
OXAIIS, $L$.

Wood-sorrel.

ACETOSELLA, $L$ 。

American Wood-sorrel.

Moist rich woods. Most abundant on the hills. Common. May - August.

VYOLACEA, $L$.

Violet-colored-flowered Wood-sorrel.

Shaded rocks and rich woods. Chariton near Schenectady, Pearson. Vicinity of Oriskany, Vasey.

Rare. April - August.

BTR ICTA, $L$.

Along roads, walls, streams.

GERANIACEA.

\section{GERANIUM, $L$.}

MACULATUM, $L$.

Moist woods, meadows.

CAROLINIANUM, L.
Upright Yellow Sorrel. Common. May - September.

Rocky barren soil, waste grounds. Schenectady, Pearson. Littlefalls, south side of the Mohawk, on the rocks. Aboat Dexter factories, Oriskany, Knieskern. High dry banks along the Black river below W atertown. Frequent in Yates county, Sartwell. Uncommon. May - July.

PUSILLUM, L.

Small-flowered Geranium.

Gravelly or sandy soil. Waste-places in Clinton. Roadsides a few miles east of Constantia, north shore of Oneida lake, Vasey. Gorham, Sartwell. Infiequent. May - September.

ROBERTIANUM, $L$.

Shady woods, rocky sides of ravines.
Herb Robert. Common. May-November.

ERODIUM, L'Héritier.

Heron's-bill.

CICUTARIUM, L'Héritier.

Water Hemlock-leaved Erodium.

Naturalized about Dexter factory, Oriskany, Knieskern. On the island opposite Constantia; along tne north shore of Oneida lake near Constantia, Vusey. Rare. June - August.

BAISAMINACEA.

Balsams。

IMPATIENS, $L$.

PALLIDA, Nuttall.
Touch-me-not. Jewel-weeds. Pale-flowered Impatiens.

Rich moist woods and ravines; forming thickets. Abundant. June - Sept.

FULVA, Nuttall.

Wet shady woods, along streams.

LIMNANTHACEÆ。

FLCERKEA, Willd.

proserpinacoides, Willd.
Fulvous-flowered Impatiens.

Common. June - August.

Low river-banks Abundant in wet woods on the fats of the Mohawk three miles below Ltica. Banks of Unadilla river, Gray. Auburn, this plant grows in the wet part of the wood, where my Carex grows, J. Carey in herb. Ham. Coll. 
RUTACEA.

Rues.

ZANTHOXYLUM, Golden.

AMERICANUM, Miller.

Prickly Ash.

Toothache Tree.

Water-courses, shores, low rich woodlands. Mohawk river. Along Wood creek, and in neighboring swampy woods. Black river. Abundant about the lakes of the north wroods. Otsego county, H. Lathrop.

Frequent. March, April.

ANACARDIACE Æ.

Cashews.

RHUS, $L$.

- Sumachs.

TYPPINA, $L$.

Rocky woods, copses, hillsides.

Staghorn, Fever Sumach.

Frequent. June.

GLABRA, $L$.

Scarlet, Smooth Sumach.

Barren grounds, rocks.

Common. July.

COPALLINA, $L$.

Mountain, Copal-like Sumach.

Rocks and dry localities. Otsego county, B.D. Gilbert. Pine plains and neal Oneida lake, Knieskern.

Infrequent. July, August.

venenata, $\boldsymbol{D} \boldsymbol{C}$.

Poison Sumach.

Swamps, open woods, water-sidès. Rotterdam, Pearson. Otsego county, $H$.

Lathrop. Oriskany swamp, Knieskern. Yates county, Sartwell. Rare. June.

\section{RADICANS, L.}

Ascending trees, covering walls, fences.

TOXICODENDRON, $L$.

Borders of woods, river-banks, waysides.

aromatica, Aiton.
Climbing Poison Ivy. Common. June.

Tree-like Poison Ivy. Common. July.

Fragrant Sumach.

Barren rocky grounds. Banks of the Black river below Watertown. In the southern tier of counties, from Binghamton westward, Knieskern. Abundant on the banks of Crooked lake, Sartwell.

Infrequent. April, May.

VITACE 正.

\section{VITIS, $L$.}

LABRUSCA, $L$.

Woods, thickets, banks of streams.

ÆSTIVALIS, Michaux.

Woods, high on trees, river banks.

CORDIFOLIA, Mich.

Fence-thickets, borders of woods, brows of ravines, water-courses.

AMPELOPSIS, Michaux.

QUINQUEFOLIA, Michx.

Moist woods, copses, walls.

RHAMNACE $\mathrm{E}$.
Common. Juee.

Vines.

Grape-vines. Wild Grape. Frequent. May.

Summer Grape.

Frequent. May.

Frost, Heart-leaved Grape.

Ivy. False Woodbine. Five-leaved Ampelopsis.

Common. June. July.

Buckthorns.

Common Buckthorn.

Purging Buckthorn.

RHAMNUS, Tourn.

C.ATH.ARTICUS, L.

Highlands of the Hudson, Barratt in herb. Ham. Coll. Common in hedges.

May; June. 
ALNTFOLIUS, L'Héritier.

Adder-leaved Buckthorn.

Cold swamps. Summit lake, Otsego county. Abundant in the high marshes of Litchiteld, State swamp and on Ilidden lake. Formerly in the ()riskany swamp. Vasey. Frequent in the marshes of the northern part of the county, and the north, woods. Yates county, Sartwell. Bergen swamp, northwesteru Genesee county. Uncommon. June.

CEANOTHUS, $L$.

Red-root. AMERICANUS, $L$. New-Jersey Tea. American Ceanothus.

Dry open woods. Schenectady. Alexandria bay. Western counties, Knieskern.

Frequent. July - August.

ovAlis, Bigelow.

Long-leaved Ceanothus.

Rocky shores. Clefts of rocks on the banks of Black river, opposite Watertown, Jefferson county; along the river between Watertown and Dexter.

Rare. May, June.

CELASTRACEA.

Staff-trees.

CELASTRUS, $L_{\text {。 }}$

SCANDENS, $L$.

Woodlands, thickets, streams.

EUONYMUS, Tourn. ATROPLRPUREUS, Jacq.

Thickets. Oneida county, H. Lathrop. Greece, Monroe county, Bradley.

Rare. June.

AMERICANUS, $L$.

Strawberry-bush. American Euonymus.

Woods, streams. Western part of the State, Torrey Fl. Western counties, Knieskern. Genesee river, Sartwell in herb. Ham. Coll.

Rare. June.

SAPINDACE E.

Soapberries.

STAPHYLEA, $L$.

TRIFOLIA, $L$.

Bladder-pod.

Copses, thickets, river-banks. Common along the Mohawk.

Frequent. May, June.

ACER, Tourn.

PENNSYLVANICUM, $L$.

Moist woodlands, ravines.

SPICATUM, Lamarck.

Thickets, steep rocky banks.

SACCHARINUM, $L$.

Woods. Common.

var. NIGRUM, Gray.

Hilly woods. Occasional. Often as a shade tree.

DASTCARPUM, Ehrhart.

Along streams. Banks of the Mohawk river throughout its length. The most common shade tree in the streets of cities, villages. Infrequent. April.

RUBRUM, $L$.

Red Maple.

Swamps. Common.
Maples. Striped Maple. Abundant. May. Spiked-flowered Maple. Abundant. June. Hard, Sugar Maple. May.

Black Maple. May.

White, Silver Maple. 
Damp meadows. Fairfield, Herkimer county, in hirb. Hadley. Southern counties, Knieskern. Greece, Monroe county, Bradley.

Rare. August, September.

\section{VERTICILLATA, $L$.}

Dry hillsides.

SENEGA, $L$.
Whorled-leaved Polygala. Frequent. June - September.

Seneca Snakeroot.

Rocks and dry woods. Schenectady. Pearson. On the sides of Black river below Watertown. Genesee valley, Greece, Bradley. Penn-Yan, Sartwell.

Rare. June, July.

POLYGAMA, Walter.

Polygamous Polygala.

Barrens, sandy woods. Pine plains west of Rome, Vasey. One mile north of New-London, Knieskern. Oneida lake, Gray. Rare. July, August.

PAdCIFolia, Willd. Gay-wings. Fringed Milkwort. Few-leaved Polygala.

Abundant at Cooperstown, in low meadows and borders of woods, Miss $S$. Cooper. Schoharie county, rare, Knieskern Pine plains of Rome, Vasey. Evergreen woods on the banks of Black river helow Watertown.

With white flowers, at Sohenectady, Pearson; and Otsego county, Mrs. J. Shaw.

Uncommon. May, June.

\section{LEGUMINOS E.}

LUPINUS, Tourn.

PERENNIS, $L$.

\section{Legumes.}

Wild Lupine. Perennial Lupine.

Sandy banks, pine woods. Plains of Schenectady, Pearson. Pine plains of Rome and Oneida lake, abundant. Near Owasco lake, I. H. Hall.

Infrequent. June.

CROTALARIA, $L$.

Rattlebox. SAGITTALIS, $L$. Arrow-leaved Crotalaria.

Rocks, sand. Rocks, Kingsbridge, N.Y., Carey in herb. Ham. Coll. Troy,. Beck in herb. Rare. June, July.

TRIFOLIUM, $L$.

Clovers. Trifolia. ARVENSE, L. Hare's-foot Trefoil. Field Clover. Dry or gravelly soil. Schenectady Pearson. Along the Central railroad. Dry borders of Oneida lake, Knieskern. Uncommon. July - September.

PRATENSE, L.

Red, Meadow Clover.

Roadsides and fields. Naturalized and cultivated. Common. May-October.

REFLEXUM, $L$. Reflexed-flowered Clover.

Opsn woods. In the neighborhood of Utica, Knieskern. Near Salina lake, Sartwell, Torrey Fl. N.Y.

REPENS, $L$. Rare. June, July.

Waysides, pastures, deep woods. Everywhere common. May - October.

AGRARIUM, L.

Yellow, Agrarian Clover.

Sandy fields. gravelly banks. Schenectady, Pearson. Along the Central railroad. Hillsides opposite Utica. Shore of Lake Ontario at Sackett's-harbor, Knieskern, Torrey Fl. Abundant in the cleared swamp west of Fort Bull, Rome. 
PROCUMBENS, L.

Hop, Procumbent Clover.

Hillsides. Tarrytown, frequent; also along the Central railroad at Skaneateles lake outlet, I. H. Hall. Searce. August.

MELILOTUS, Tourn.

OF FICINALIS, Willd.

Sweet Clover.

River-banks and roadsides. Not infrequent throughout the valley of the Mohawk. Troy. Schenectady, Pearson. Fort-Plain, B. D. Gilbert. Littlefalls; Utica; Deerfield.

Uncommon. July - September.

$A L B A$, Lamarck.

White-flowered Melilot.

Roadsides and railroads. Utica. Syracuse. Auburn, Hall.

Frequent. July - October.

MEDICAGO, $L$.

Nonesuch. Black Medick.

LUPULIN A, L.

Hop-like Medicago.

Waste places, streets, railroads,

Common. May - November.

M.ACULAT A. Willd .

Spotied-leaved Medicago.

Barren grounds. About the Dexter factories, Oriskany, introduced among wool, Vasey.

Scarce. June - September.

AMORPHA, $L$.

FRUTICOSA, $L$

var. LEWISII.

$$
\text { False Indigo. }
$$

Shrubby Amorpha.

Collected by Lewis.

Gravelly banks, along the Hudson river railroad, Tarrytown, well established, I. H. Hall.

June, July.

ROBINIA, $L$. PSEUDACACIA, $L$.

Locusts.

False-acacia Robinia.

A common shade tree. Banks of the Hudson near Troy, Beck in herb. Extensively cultivated along the Central railroad, between Utica and Schenectady, for timber.

May, June.

TEPHROSIA, Pers.

virginiana, Persoon.

Hoary Pea.

Virginian Tephrosia.

Sterile hills and sandy woods. Schenectady plains, Pearson. Fainfield, Herkimer county, in herb. Beck. Junius, Seneca county, Sartwell in herb. Ham.

Coll. Greece, Monroe county, Bradley. Rare. June - August.

ASTRAGALUS, $L$.

CANADENSIS, $L$.

Milk-vetch.

Banks and shores. Along the east side of Onondaga lake. Seneca lake, Sartwell in herb. Ham. Coll.

Rare. June, July.

\section{COOPERI, Gray.}

Discovered by William CoOper.

Gravelly sides of lakes. Slopes along Onondaga lake between Salina and Liverpool. Rare. July, August.

DESMODIUM, $D C$. NUDIFLORUM, $D C$.

Tick-trefoils. Desmodia. Naked-flower-stemmed Desmodium.

Open woods, along streams. Schenectady, Pearson. Valley of the Mohawk. Frequent. July - August.

ACUMTNATUM, $D C$.

Rich moist woods, bottoms of ravines.
Acuminate-leafleted Desmodium, Common. August. 
ROTUNDTFLIUM, $\boldsymbol{D} C$.

Round-leafleted Desmodium.

Dry rocks and sand. Pine plains of Rome, Knieskern. Woods north of Auburn, Hall. Junius, Sartwell in herb. Oak openings of Greece, Bradley.

CANESCENS, $D C$.

Canescent Desmodium.

Damp woods, thickets Schenectady, Pearson. Seneca Jake, Beck in herb. Gorham, Ontario county, Sartwell in herb. Ham. Coll. Rare. July, August.

CUspidateM, Torr. \& Gr.

Cuspidate-bracted Desmodium.

Shaded streams. Fort Hill Cemetery, Auburn, in a deep rich glen, $1 . H$. Hall. Schenectady, Beck in herb. Yates county. Sartwell in herb. Ham.Coll.

Rare. August.

VIRIDIFLORUM, Beck.

Green-flowered Desmodium.

Sandr woods, copses. Cemetery of the old Dutch Church and along the river, Tarrytown, Hall. Plains of Schenectady, Pearson. Herkimer connty, Beck in herb. Seneca lake. Sartwell.

Rare. July - September.

DILlENII, Darlington.

Diluenius's Desmodium.

Copses, dry woods and fields. Tarrytown, I. H. Hall. Penn-Yan, Yates county. Sartwell.

Scarce. July, August.

PANICULATUM, DC.

Panicled Desmodium.

Open woodlands, borders of thickets. Dexter, Jefferson county, Vasey.

Frequent. August.

Canadense, $\boldsymbol{D} C$.

Canadian Desmodium.

Dry woodlands. Otsego county, H. Lathrop. Near Oriskany, Knieskern. Auburn and Elbridge, Hall.

Frequent. August.

CILIARE, DC.

Fringed Desmodium.

Sands. Pine plains of Rome, Knieskern. Yates county, Sartwell.

Uncommon. July, Angust.

MARILANDICUM, Boott.

Maryland Desmodium.

Sandy fields, borders of thickets. Schenectady plains, Pearson. Southern counties, P. D. K. in herb. Ham. Coll. Yates county, Sartwell.

Infrequent. August.

LESPEDEZA, Michx.

PRocumbens, Michx.

Bush Clovers.

Reclining Lespedeza.

Dry sandy woods and open fields. Tarrytown, I. H. Hall. Pine plains of

Schenectady, E. W. Paige. Yates county, Sartwell.

Rare. August.

REPENS, Torr. \& G $r$.

Prostrate Lespedeza.

Common in sandy soil about Tarrytown, not always in dry places, $I . H$ Hall.

Rare. June - August.

violacea, Persoon.

Violet-flowered Lespedeza.

Gravelly banks, thickets. Alexandria bay. Penn-Yan, Yates county, Sartwell.

var. DIvergens, Torr. \& Gr. Loose-flowering Lespedeza. Junius, Seneca couuty, Sartwell in herb. Hem.Coll.

var. sessiltfloRA, Torr.\&. Gr. Close-flowering Lespedeza. Schenectady, Pearson.

var. Angustifolia, Torr. \& Gr. Narrow-leaved Lespedeza. Near the Aqueduct, Schenectady, Pearson. Frequent. July-September.

STUVEI, Nuttall.

Discovered by W. STuve.

$[\mathrm{ON}, \mathrm{PL}$.

Sandy woods east of Tarrytown, not common, I. H. Hall. Kare. August. 
HIRTA, Elliott.

Hairy Lespedeza.

Rocks and woods near the river. Tarrytown, Hall. Schenectady, Pearson. Alexandria bay. Yates countr, Sartwell in herb. Hrin. Coll. Infrequent. August, September.

CAPITATA, Michx.

Capitate-flowering Lespedeza.

Hillsides, borders of woods. Tarrytown. I. H Hall. Albany, Beck in herb. Plains of Schenectady, Pearson. Pine barrens of Rome, Vasey. Alexandria bay, Jefferson county.

Abundant. August, September.

VICIA, Tourn.

Tares. Vetches.

S.ATIV.A, L.

Cultivated Vetch.

Borders of fields, along ditches. Common through the valley of the Mohawk. June, July.

TETRASPERM.A, L.

Four-seeded Vetch.

Banks of the Hudson in the shade, Tarrytown, Hall. Albany, Beck in herb. Rare, June - August.

CRACCA, $L$.

Cracca Vetch.

Plains of Schenectady, Pearson. Sandy fields on Paris hill. Between Oriskany and Rome, along the Central railroad. Rare. June - September.

CAROLINIANA, Walter.

Carolina Vetch.

Brooksides along the Mohawk. Below Utica. Yates county, Sartwell.

americana, Muhl.

American Vetch.

Shady places along streams. Seneca lake, Gray. Penn-Yan, Sartwell. Greece, Bradley.

Scarce. June.

LATHYRUS, $L$.

Maritimus, Bigelow.

Vetchling.

Sandy shores of Oneida lake, Knieskern. Shore of Lake Ontario, Gray.

Rare. June, July.

OCHROLEUCUS, Hooker.

Cream-colored-flowered Lathyrus.

Shaded banks. Watertown, Jefferson county, Crawe; Gorham, Ontario county. Sartwell; Gray in Rare plants of Northern N.Y. Monroe county, C. M. Booth. Rare. June, July.

PALUSTRIs, $L$.

Marsh Lathyrus.

Borders of marshes, rivers, lakes. Banks of the Mohawk; and of the St.

Lawrence at Alexandria bay. Genesee river below Rochester, Sartwell. Scarce. July - September.

var. MyRtifolius, Gray.

Myrlle-leaved Lathyrus.

Shores. Northern N.Y., Gray in New and Rare plants. Seneca lake, Sartwell in herb. Ham. Coll.

Rare. July, August.

PHASEOLUS, $L$.

PERENNIS, Walter.

Kidney Bean.

Hillsides. Tarrytown, Hall. Yates county, Sartwell. Rare. July, August.

APIOS, Boerhaave.

TUBERosa, Mrench.
Glycine. Ground-nut.

Tuberous Apios.

Thickets near water. West of Schenectady, Pearson. West bank of Otsego lake, Miss S. Cooper. Banks of the Mohawk river. Oriskany swamp, Knieskern. Alexandria bay, Jefferson county. A bundant on Owasco lake outlet, I. H.Hall. Greece, Monroe county, Bradley. Frequent. July-September. 
AMPHICARP EA, Elliott.

Ground Peanut.

monotca, Nuttall.

Damp thickets, rich wet woods.

Monæcions Amphicarpaa.

Common. July-October.

BAPTISIA, Ventenat.

Wild Indigo.

timctorta, $R$. Bronon.

Dyeing Baptisia.

Dry wonds and sandy soil. Between Sehenectady and Amsterdam. Pearson.

Saratoga county, L. Collins. Junius, Seneea county. Sartwell in herb. Ham.

Coll. Greece, Mouroe county, Bradley. Vicinity of Rochester, C.M.Booth. Scaree, Jane - August.

CASSTA, $L$.

Wild Senna.

MARILANDICA, $L$.

Maryland Cassia.

Rich moist banks. Abundant about Ballston lake, Pearson. Chenango valley, Knieskern.

Uneommon. July, August.

CHAMECRISTA, $L$.

Dwarf, Ground-touching Cassia.

Sandy hills and gromuds. Albany, Beck in herb. Whitesboro. Dr. Gates in herb. Beck. Often introduced into gardens. July - October.

Nictitans, $L$.

Sensitive-plant. Closing Cassia.

Banks of gravel or sand. Common at Tarrytown, I. H. Hall. From the North river, Sartwell in herb. Ham. Coll. Troy, Beck in herb.

Rare. July - September.

GYMNOCLADUS, Lamarck.

CANADENSTS, Lam.

Coffee-tree.

Canadian Gymnocladus.

Rich bottoms along streams and shores Near Cayuga lake, Thompson in Torrey Fl. N.Y. Ithaca, in herb. Van Duzee. Seneca lake, Sartwell in herb. Ha:n. Coll. Rare. May, June.

ROSACEA

Roses.

PRUNUS, $L$.

americana, Marshall.

Plums. Cherries.

Wild Plum.

Thickets on river-banks, along fences. Common over the flats of the Mohawk.

April.

SPINOS.A, L.

Roadsides and old fields.

Thorny Plum.

DOMESTICA, L.

Frequent. April.

Common in the northern part of the county, spontaneous on edges of gardens, dooryards, and forming thickets along fences.

May.

PCMILA, $L$.

Dwarf Cherry.

Sterile rocks and sand. On the plains of Schenectady, Pearson. Clefts of rocks by the side of Black river opposite $W$ atertown, Jefferson county.

Rare. April, and early in May.

PENNSYLVANICA, $L$.

Bird, Red Cherry.

Abundant in clearings and ground recently burned over. Common in the fields of the north woods reverting to wilderness. The worthless successor of the noble Spruce and valuable Pine. There is, however, only one generation : after a few years, having attained the height of about thirty feet, they dic and fall, to be replaced by the hard woods.

May.

VIRGINIANA, $L$.

Borders of woods, thickets, river-banks.
Car inat, Cintie Cherry.

Counmon. June. 
SEROTINA, Ehrhart.

Black, Lale Cherry.

Woods, fences and water-conrses. Formerly abundant, now searee. June.

VULGARIS, Miller.

Common, Sour Cherry.

Frequent beside gardens, walis, roadsides.

April.

SPIR玉A, $L$.

Merdowsweet.

OPULIFOLIA, $L$.

Opulus-leaved Spirca.

Rocky woods and water-sides. Alhany, Beck in herb. Banks of Norman's kill, Schenectady county E.W. Paige. Otsego county, H. Lathrop. Ithaca, Tompkins county, Sartwell in herb. Ham. Coll.Rare. Jane, July.

SALICIFOLIA, $L$.

Willow-leaved Spircea.

Swamps, meadows, banks of brooks. Common throughout the valley of the Mohnwk. Burders of lakes, along streams and in beaver meadows of the north woods. Alexandria bay on the St.Lawrence. Frequent. July - Sept.

TONENTOSA, $L$.

Hardhack. Tomentose Spircea.

Sterile soils, pastures. Schenectady. Pearson. Saratoga county, L. Collins. Otsego county, H. Lathrop. Low grounds in the northern part of the State. Scarce. July - September.

GILLENIA, Mœnch.

Indian Physic.

TRIFOLIATA, Monch.

Trifoliate Gillenia.

Rich open woods and thickets. Bridgewater, Gray in herb. Beck. Near Waterville Miss $J E$. Johnson. Sides of the Oriskany ralley from Clinton southward, Dr.John A. Paine. Banks of Seneca lake, Vasey. Rare. June.

AGRIMONIA, Tourn.

EUPATORIA, $L$.

Common Agrimony.

Waysides, ravine-bottoms.

The Ancient Eupatorion.

Common. June - September.

SANGUISORBA, $L$.

Burnet.

CANADENSIS, $L$.

Canadian Sanguisorba.

Wet rocks, low meadows, swamps. Wet flats of the Mohawk between Utica and Frankfort. Cedar swamp, Oriskany, Knieskern. Above Trenton falls towards Prospect, rucks near the creek. Deep cedar swamp on Paris hill. Borders of Hidden lake, Litchfield. Fish ereek. Victor, Ontario county, Bradley.

Scarce. July - October.

GEUM, $L$ 。

ALBUM, Gmelin.

Avens. Geum.

Damp wocds and their borders.

White-flowered Avens.

VIRGINIANUM, $L$.

Virginian Avens.

Common in swamps on the flats of the Mohawk, especially in the damp cleared grounds; also in the thickets along the river-banks.

Rare elsewhere. June, July.

strictum, Aiton.

Swamps, woods, low pastures, fences.

RIVALE, $L$.

Cedar swamps and wet meadows.

TRTFLORUM, Pursh.

On rocks, Watertown, Jefierson county; very rare, Crawe, Torrey Fl.N.Y.
Yellow, Upright Avens.

Common. June - August.
Nodding, Purple, Rivulet Avens.

Common. May - July.

Three-flowered Avens. May, June. 
WALDSTEINIA, Willd.

Barren Strawberry. FRAGARIOIDES, Trattinick,

Strawberry-like Waldsteinia.

Dry woods under the shade of hemlocks or arbor vitæ, hillsides of streams, sometimes in swamps. Frequent. May - August.

POTENTILLA, $L$.

Cinquefoils. NORVEGICA, $L$.

Roadsides, fields, pastures.

Norwegian Potentilla. Common. June - August.

CANADENSIS, $L$.

Canadian Potentilla.

Sandy wastes. Common at Schenectady, Pearson. Pine plains, Rome, and sandy fields near the head of Oneida lake, Knieskern.

Frequent. May - September.

var. PUMILA, Torr. \& Gr.

Old pastures.

var. SIMPLEX, Torr. \& Gr. Copses and clearings.

ARGENTEA, $L$.

Chiefly on rocks and gravelly banks. Schenectady. Littlefalls. Below Watertown. About Oneida lake.

ARguta, Pursh.

Sharp-serrated-leaved Potentilla.

Open rocky hills, Tarrytown, $I$. H. Hall. Sides of Wolf hollow, Schenectady county, E. W. Paige.

ANSERINA, $L$.

Silverweed. Goose Potentilla.

Shores of rivers and lakes. Near Sanders's lake, Pearson. Borders of Otsego lake, B. D. Gilbert. Common all round Onondaga lake. Crooked lake, Sartwell.

Rare. June - November.

FRUTICOSA, $L$.

Shrubby Potentilla.

Cold swamps. Summit lake, on the hill-top between Fort-Plain and Cooperstown, source of the Susquehanna, where it covers acres of open marsh land. Abundant on the eliffs of $\mathrm{F}$ ish creek from Taberg, northward; especially near Fall brook, hanging from the clefts of the rocks as far and as high as the eye can reach. It has been found also at Junius, Seneca county, by Sartwell; at Greece, Monroe county. by Bradley; at Bergen, Genesee county, by G.T.Fish; and at Avon, Livingston county, by G.W. Clinton. Rare. June - August.

\section{PALUstris, Scopoli.}

Marsh Potentilla.

Cold marshes. Summit lake, Otsego county. Hidden lake. Litchfield. Swamp west of Fort Bull, Rome. Abundant in the streams and low lands at the head of Oneida lake. Common on the marshes in the northern part of the county, and about the lakes of the north woods. Rare. May-September.

FRAGARIA, Tourn.

VIRGINIANA, Ehrhart.

Woods, pastures, meadows. Everywhere.

Strawberries.

Wild Strawberry.

April - October.

VESCA, $L$.

Alpine, Edible Strawberry.

Rocks, around old stumps and logs, evergreen woods.. Common. May.

A variety with different leaves and bearing white fruit, occurs rarely in the north woods. Trenton falls, borders of the wood south of Moore's Hotel, William Calverly. Also Delaware county, B. D. Gilbert.

June.

DALIBARDA, $L$.

Dewdrop. False Violet. REPENS, $L$.

Moist banks, evergreen woods and swamps.
Creeping Dalibarda.

Common. May - August. 
RUBUS, $L$.

ODORATUS, $L$.

Cliffs, steep banks and ravine sides.

TRIFLORIS, Rirhardson.

Damp shaded woods and swamps.

A torm with pink-eolored fowers the rocks are constantly wet.

STRigosus, Michx.

Roadsides, fences, borders of woods. Common on clearings. May - July.

OCCIDENTALIS, $L$.

TIysides, walls, thickets.

VTLLosus, Aiton.

Open woods and cleared land. Common.

var. FRoNDosus, Torrey.

Littlefalls, Gray in herb. Ham. Coll.

var. HUMIFUSU, Torr. \& Gr.

Tates county, Sartwell in herb. Hain. Coll.

var. is found growing spontaneously near Cooperstown, Otsego county, by $\mathrm{Dr}$. Horace Lathrop.

CANADENSIS, $L$. Dewberry. Canadian Blackberry.

Barren banks and borders of swamps. North woods. Frequent. May.

HISPIDUS, $\boldsymbol{L}$.

Wet woods and sphagnum swamps.

ROSA, Tourn.

SETIGERA, Michx.
Black, Western Raspberry. Common. May, June.

High, Villons Blackberry.

Leafy-bracted Blackberry.

Trailing Blackberry.

The White Blackberry, May, June. Ravine of Chittenango ereek below the falls. Penn-Yan, Sartwell.

Escapes occasionally. July, August.

CAROLINA, $L$.

Sramp Rose.

Borders of swamps, and grassy bogs along streams.

Common. July - September.

LUCJDA, Ehrhart.

Dwarf, Bright-leaved Rose.

Old fields and sandy open woods. Schenectady, Pearson. Otsego county, Miss S. Cooper. Yates county, Sartwell. Uncommon. June, July.

BLANDA, Aiton.

Early, Thornless Rose.

Abundant on banks and knolls on the flats of the Mohawk. About Otsego lake, Miss S.Cooper. Coon Chisholm's, Schenectady, Pearson.

Frequent. May, June.

RUBIGINOS $\mathcal{A}, \mathrm{L}$.
Uncultivated fields, pastures.

Sweetbrier. Eglantine. Rusty Rose.

Uncultivated fields, pastures. Common. June, July.

CINNAMOMEA, Besler.

Cinnamon Rose.

var. FECUNDISSIMA, Lindley.

Double Cinnamon Rose.

Forming thickets about dwellings, fences, roalsides. Common. May-July • 
CRAT AGUS, $L$.

Thorn-bushes.

OXYACANTH.A, L.

Hedges and fields.

Hawthorn. Sharp-spined White Thorn.

Frequent. May.

COCCINEA, $L$.

Borders of sandy or rocky woods.

Scarlet-fruited Thorn.

TOMENTOSA, $L$.

Abundant. May, June.

Thickets, old pastures. Along fences and ditches on the flats of the Mohawk.

Common. May.

var. PYrifolia, Gray.

Pear-leaved Thorn.

Thickets on sandy or gravelly soil. Schenectady, Pearson.

Scarce. May, June.

var. PUnCtatA, Gray.

Dotted-fruited Thorn.

Open low bottoms of streams on the flats of the Mohawk, forming thickets with the willows.

Common. May.

CRUS-GALLI, $L$.

Cockspur Thorn.

Hedges, roadsides, banks of streams.

Abundant. June.

PYRUS, $L$.

Apple. Pear.

CORONARIA, L.

Fragrant Crab-apple.. Garland Pyrus.

Open woods about Oriskany, Knneskern. Yates county, indigenons, Sartwell. Rare. May.

M.ALUS, L.

Common Apple. The Classical Malus.

Neglected fields, borders of woods. A stunted form in old pastures. roadsides.

Frequent. May.

ARBUTIFOLIA, $L$.

Arbutus-leaved Pyrus.

Borders of swamps.

Common.

var. ERтthrocarpa, Torr. \& Gr. Red-fruited Chokeberry. Sphagnum swamps, water-sides.

var. MELANOCARPA, Torr. \& Gr. Black-fruited Chokeberry.

Sandy plains and on rocks.

May.

AMERICANA, $D C$.

Mountain-ash. American Pyrus.

Cold swamps. Graefenberg hill, southeast of Utica. Swamps on the Pine plains; low deep woods near Oneida lake. Abundant along the streams and lakes of the north woods, where it is a high tree. June.

AMELANCHIER, Medik.

Juneberry.

CANADENsis, Torr. \& Gr.

Shadbush.

River banks, ravine-sides, low thickets.

Common.

var. вотRYAPIUM, Torr. \&・ Gr. Pyriform-clustered-flowered

Sandy or rocky woods. Abundant.

Juneberry.

var. oblongIfolia, Torr. \& Gr. Long-leaved Juneberry.

Borders of woods, and streams.

Common.

var. вотUndFolia, Torr. \& Gr. Round-leaved Juneberry.

Low sandy woods. Borders of Crooked lake, Sartwell. Uncommon.

var. oligocarpa, Torr. \& Gr. Few-fruited Juneberry.

Wet mountain swamps, New-York, Torrey \& Gray. On mountains in the northern part of the State, Torrey Fl. N.Y, Rare, April, May, 
MELASTOMACEA.

Melastomas.

RHEXIA, $L$.

VIRGINICA, $L$.

Deer-grass. Meadow Beauty.

Viryinian Rhexia.

Low sands and shores. About Oneida lake near Constantia, Vasey. Between the mouth of Fish ereek and Rotterdan, near the lattro place. Kniesleen. Rare. June - September.

\section{LYTHRACE A.}

Loosestrifes.

LYTHRUM, $L$.

True Loosestrife. SALICARIA, $L$.

Spiked, Willow-like Loosestrife.

Swamps. Junius, Wayne county, Surtwell in herb. Ham. Coll. Rochester, C. Dewey.

Rare. July, August.

NES AA, Comm.

Verticillata, $H . B . K$.

Swamp Loosestrife. Lake shores, borders of ponds in sphagnum swamps. Ballston lake, Pearson. Fairfield, Hadley in herb. Wetmore's sphagnum pond, Frankfort hill. Marsh at the head of Oneida lake, Knieskern.

Uncommon. August.

CUPHEA, Jacquin.

VISCOSISSIMA, Jacq.

Cuphea.

Very-clammy Cuphea.

Old fields and gravelly places, northern part of the State, Stevenson and Knieskern, Torrey Fl. N.Y.

Rare. August.

ONAGRACEA.

EPILOBIUM, $L$.

ANGUSTIF OLIUM, $L$. Copses and new lands : even in the north woods, springing up abundantly after fires.

Common. July - September.

PALUSTRE, L. : var. LINEARE, Gray.

Linear-leaved Epilobium.

Cold mossy swamps. Litchfield, near Jerusalem hill; Hidden lake, on its borders, under cedars and tamaracks. Abundant in the sphagnum swamps and beaver meadows of the north woods.

The small few-flowered form, $\boldsymbol{E}$. oliganthum, Michaux, on the hills about Oriskany, Vasey.

MOLLE, Torrey. Scarce. July - Seytember.

Downy Epilobium.

Wet banks. Hungry kill beyond Coon Chisholm's, Schenectady, Pearson. Summit lake, Otsego county. Hidden lake, south Herkimer county. Bridgewater, Gray in herb. Ham. Coll. Damp meadows neal Oriskany, Knieskern. Common on cold marshes in the northwestern part of the county. near Fish creek and Point of Rock lake. Common. August, September.

Coloratum, Muhl.

Low grounds, brook-sides.

ENOTHERA, $L$.

BIENNIS, $L$.

Railroads, roadsides, waste fields.

var. MURICATA, Torr. \& Gr.

Schenectad5, Pearson.

var. GRANDIFLORA, Torr. \& Gr.

Low grounds. Flats of the Mohawk.
Colored-leaved Epilobium. Frequent. July-October.

Evening Primroses. Biennial Eiening-primrose.

Prickly Evening-primrose.

Large-flowered Eveningprimrose.

Common. June - August. 
FRTTICOSA, $L$.

Shrubby Evening-primrose.

Open sandy woods. Schenectady, Pearson. Delaware county, B.D.Gilbert. Near Rochester, C. M. Booth.

Infrequent. July.

CHRisantha, Michx.

Golden-flowered Evening-primrose.

Rocky woods and bauks of streams. Ravine between Ner-Hartford and Paris hill. Bridgervater, Gray, and Perch lake, W. $A$. Wood in herb. Hann. Coll. Near Oswego, Knieskern, Torrey Fl. N.Y. Frequent. July, August.

PCMILA, $L$.

Dwarf Evening-primrose.

Sandy fields, cleared uncultivated land, poor meadows.

Common. June, July.

GAURA, L.

Gaura.

BIENNIS, $L$.

Biennial Gaura.

Drs fields and river-banks. Along the Mohawk at Fort-Plain, B.D.Gilbert. In a berry field on Graefenberg hill, J. G. Crocker. Banks of Seneca lake, Gray in herb. Beck, Sartwell in herb. Ham. Coll. Owego, Tioga county, Knieskern. Parma, Monroe county, Bradley. Scarce. Augnst-October.

LUDWIGIA, $L$.

False Loosestrifes. ALTERNIFOLIA, $L$.

Seedbox. Alternate-leaved Ludwigia.

Borders of swamps in Tarrytown-and wet woods in Westchester, Hall. Albany, G.W. Clinton in herb. Beck. Schenectady, on the banks of the Mohawk, Pearson.

Rare. July, August.

PALUSTRIs, Elliott.

Muddy edges of pools and streams.

Marsh Ludwigia. Common. June - October.

CIRC丑A, Tournefort.

LUTETIANA, $L$.

Damp woods.

ALPINA, $L$.

Shaded springs banks, ravine-sides,

PROSERPINACA, $L$.

PALUSTRIs, $L$.

Enchanter's Nightshade. Mignonette-like Circcea. Common. June, July.

Mountain Circca.

Common. July, August.

Stagnant water, ponds. Albany, Beck in herb. In a beaver meadow south of Vernon, J.S.Douglass, Knieskern. Gorham marshes, Ontario county, Sartwell.

Scarce. July, August.

PECTINACEA, Lamarck.

Pectinate-leaved Mermaid-weed.

Ditches in a beaver meadow near Vernon village, J.S. Douglass, Knieshern cat.

Rare. July.

MYRIOPHYLLUM, Vaillant. SPICATUM, $L$.

Water-milfoils.

Ponds, lakes. Tates county, Sartuell in herb. Ham. Coll. Irondequoit bar, Monroe county, C. M. Booth.

Rare. July, August.

VERTICILLATUM, $L$.

Whorled-flowered Myriophyllum.

Still waters. Sander's lake, Pearson. Oneida county, Knieskern.

Uncommon. July - September.

HETEROPHYLLIM, Michx.

Variable-leared IIyriophyllum.

Pools and marshes. Borders of the Irondequoit bas of Lake Ontario, C. $M$. Booth.

Scarce. June - August.

[ON. PL.] 
TENELLUM, Bigelow.

Slender Myriophyllum.

Ciravelly bottoms of ponds in shallow water. Northern part of the State, Torrey $F l . N . Y$.

Rare. July, August.

HIPPURIS, $L$.

Mare's-tail.

VULGARIS, $L$.

Common Hippuris.

Lakes. Sander's lake, Scotia, Pearson. Schuyler's lake, Otsego county;

Alexandria bay, G.W. Clinton. Cayuga lake, J. Smith in herb. Ham. Coll.

Rare. June - August.

CACTACEA.

Cactus.

OPUNTIA, Tourn.

vUlgaris, Miller.
Prickly Pear. Indian Fig.

Common Opuntia.

Rocks and sands. The most northern locality in the State is Fairfield, Herkimer county, where it was found by Prof. Hadbex, Torrey Fl. N.Y. In herb. Hadley, without habitat.

June, July.

GROSSULACE平。

Currants.

RIBES, $L$.

CYNOSBATI, $L$.

Hillsides.

Hirtellum, Michx.

Gooseberries. Currants. Prickly, Dog-bramble Gooseberry.

Common. May. Ham. Coll.

Hairy Gooseberry.

ROTUNDIFOLIUM, Mich.

Frequent. May.

Cold swamps. Abundant in the State swamp near Jếrusalem hill. Hidden lake.

June.

lactstre, Poiret.

Swamp Gooseberry.

Upland swamps, northern part of the State, Torrey $F l$. N.Y. Hanging from wet rocks, in the spray from Fall brook, four miles north of Taberg. More above, along Fish creek.

Prostratum, L'Héritier.

Rare. May, June.

Common in cold cedar swamps, and along woodland brooks on the hills. May.

FLORIDUM, L'Héritier.

Wet woods and open grounds.

RUBRUM, $L$.

Prostrate Currant.

Swampy woods, low shaded flats of streams, hillsides and wavines. Frequen.

Flowering Currant.

Common. May.

Red Currant.

The true native variety, along a small stream on hills north of Salmon falls : different from the Red Currant of the gardens, Vasey. May.

\section{CUCURBITACEA.}

Cucumbers.

SICYOS, $L$.

ANGULATUS, $L$.
Single-seeded Cucumber. Angular-leaved Sicyos.

Waste places in and near cities; occasional along streams. Common in Utica. July - October.
ECHINOCYSTIS, Torr.\& Gr.

LоватA, Torr. \& Gr.
Prickly Cucumber. Balsam-apple. Lobed-leaved Echinocystis.

River-bottoms. Common throughout the valley of the Nohawk, on all parts of the flats, from the river banks, along fences and brooks to the hills. 
Takes possession of shaded banks in gardens and lawns. May - July.

TELEPHIOIDEs, Mich $x$.

Orpine-like Sedum.

High on the eliffs at Chittenango falls; where it hangs from clefts and seats of the rocks, within reach of the spray.

June.

TELEPHIUM, L.

Orpine. The Ancient Telephion.

Gravelly banks and shores. Common down the valley of the St.Lawrence; on the Thousand Islands, at Alexandria bay. Escapes into roads, fences, banks. Littlefalls. Trenton. Utica. Frankfort hill. August - September.

PENTHORUM, Gronovius.

SEDOIDES, $L$.

Roadsides, ditches, swamps.

SAXIFRAGACE E.
Ditch Stonecrop.

Sedum-like Penthorum. Common. July - September.

Saxifrages.

SAXIFRAGA, $L$.

AIZOIDES, $L$.

Aizoon-like Saxifraga.

Wet cliffs on the east branch of Fish creek. Discovered many years ago, by Knieskern and Vasey, at its lowest station between the Railroad and Taberg, on an upright rocky side, wet by a brook pouring over into the creek; in company with Primula mistassinica. Herc, however, there are only a few plauts, on the space of a few square feet, wanderers from the multitude above. The creek comes from the north for many miles through a deep ravine, and, fluwing from one side to the other, causes upright rocky precipices, which vary in height from fifty to one hundred and twenty-five, and in length from one hundred to one thousand feet. The woods still remain above, so that these precipices are always wet with dripping water. On these cold wet rocks. in shade or looking towards the north, the Yellow Mountain Saxifrage abounds, frequently in mats. It bears many flowers, and the golden clusters, visible at a distance, may be found in June.

Local.

VIRGINIENSIS, Michx.

Early, Rock Saxifraga.

Rocks. Little falls; Trenton falls; Fish creek; Chittenango falls; Black river; Alexandria bay.

Frequent. April, May.

PENNSYLVANICA, $L$.

Low borders of streams, swamps.

MITELLA, Tourn.

DIPHYLLA, $L$.

Woods and ravine-sides.

NCDA, $L$.
Swamp Saxifraga.

Common. June.

Fringe-cup. Mitre-wort. Two-leaved-stemmed Mitella.

Common. April, May.

Leafless-stemmed Mitella.

Arbor-vitæ swamps. Common about decaying stumps and logs, overrunning them, in damp moss and deep shade, with Listera cordata and Corallorhiza innata, a beautiful and interesting plant.

TIARELLA, $L$.

Frequent. May, June.

CORDIFOLIA, $L$.

Hilly woods.
Bishop's-cap.

Cordate-leaved Tiarella.

Common. May.

CHRYSOSPLENIUM, Tourn.

AMERICANUM, Schweinitz.

Golden Saxifrage.

American Chrysosplenium.

Swamps, springy places, rivulet borders, in the shade.

Common. April, May. 
HATAMELACEA.

Witch-hazels.

HAMAMEJIS, $L$.

Witch-hazel.

VIRGINICA, $L$.

Hamamelis.

Low woods and thickets; sides and bottoms of ravines.

Common. September - November.

UMBELLIFER E.

HYDROCOTYLE, Tourn. AMERICANA, $L$.

Springy banks, brooks, wet rocks.

UMBELLATA, $L$.

Springs and shores. Near Albany, Beck and Tracy, Torrey Fl. N.Y.

Rare. June - August.

SANICULA, Tourn.

CANADENSIS, $L$.

Dry woods and thickets.

MARILANDICA, $L$.

Swamps, damp woodlands.

DAUCUS, Tourn.

C.AROTA, L.

Wild Carrot.

Common Carrot.

Railroads, roadsides, waste places. Banks of the Mohawk, Pearson. Near Utica. Auburn, I. H. Hall.

Uncommon. June - September.

HERACLEUM, $L$.

LANATUM, Michx.

Cow Parsnip.

Woolly Heracleum.

Flats of streams, low meadows. Common in the valley of the Mohawk. June.

PASTINACA, Tourn.

S.ATIVA, L.

Roadsides, fences, banks of streams.

ARCHANGELICA, Hoffmann. Hirsuta, Torr. \& Gr.

Borders of woods. Albany, Beck in herb. Yates county, Sartwell in herb. Ham. Coll. About Rochester, C.M. Booth.

Common, Sowed Pastinaca.

Common. July.

Archangelicas.

Downy Archangelica.
ATropurpurEA, Hoffm.

Dark-purple-stemmed Archangelica.

Common on the flats of the Mohawk throughout.

CONIOSELINUM, Fischer.

CANADENSE, Torr. \&. Gr.

Cold swamps, in shade. Oriskany swamp, a very rare plant, Knieskern. On the banks of Chenango river, Knieskern, Torrey $F l . \mathbf{N} . \boldsymbol{Y}$.

Rare. August, September.

ATHUSA, $L$. CYNAPIUM, L.

Fool's Parsley. Dog's-poison Ethusa.

Waste places in cities, villages. Common in Clinton. July, August. 
THASPIUM, Nuttall.

BARBINODE, Nuttall.

Meadow Parsnip.

Fringed-jointed Thaspium.

Borders of woods and rivers. Valley of the Chemung river, Knieskern, Torrey $F l . N . Y$. Genesee valley, abundant, C.M. Booth.

Scarce. June, July.

AUREUM, Nutiall.

Golden-flowered Thaspium.

Wet meadows and along streams.

rar. APTERUM, Gray. Wingless-fruited-sharp-leaved Thaspium. Open woods and damp meadows, Oriskany, Knieskern.

Frequent. May, June.

TRIFOLIATUM, Gray.

Three-parted-leaved Thaspium.

var. APTERUi, Gray. Wingless-fruited-round-leaved Thaspium. Meadows. Yates county, Sartwell in herb. Ham. Coll. Rare. May.

ZIZTA, $D C$.

Zizia.

INTEGERRIMA, $D C$.

Perfectly-entire-leaved Zizia.

Dry woods and rocks. Abundant in the pine woods of Schenectady county. Gravelly borders of Oneida lake, Knieskern. Roct-y banks of the Black river below Watertown.

Scarce. May, June.

CICUTA, $L$.

MACULATA, $L$.

Wet meadows, streams, swamps.

Water Hemlock. Spotted-stemmed Cicuta. Common. July, August.

BULBIFERA, $L$.

Bulb-bearing Cicuta.

Borders of marshes, creeks, lakes. Common in the north woods.

Frequent. August.

SIUM, $L$.

Lineare, Michx.

Shady swamps.
Water Parsnip.

Linear-leaved Sium.

Common. July, August.

CRYPTOT ENIA, DC. CANADENSIS, $D C$.

Honewort.

Canadian Cryptotenia.

Shaded places; about dwellings, orchards. Frequent in rich woods, and common in thickets on the banks of the Mohawk. Abundant. June-Aug.

OSMORRHIZA, Rafinesque.

LONGISTYLIS, $D C$.

Fertile open woods.

BREVISTYLIS, $D C$.

Rich woods, ravines.

CONIUM, $L$.

$M . A C U L A T U M, \mathrm{~L}$.
Sweet Cicely. Long-styled Osmorrhiza. Uncommon. June, July.

Short-styled Osmorrhiza. Common. June - August.

Poison Hemlock. Spotted-stemmed Conium.

Fences, waste places, damp banks. Frequent in towns, roadsides. Common on the banks of the Erie canal; Schenectady; Littlefalls; Herkimer; Utica: often forming thickets. July.

CARUM, $L$.

Caraway.

CARUI, L.

Common Carum.

Roadsides, remote from dwellings, naturalized. Frequent. May - July. 
ARALIACEA.

Aralias.

ARALIA, Tournefort.

RACEMOSA, $L$.

Sarsaparilla.

Fertile woodlands; sides and bottoms of ravines. Abundant. July, August.

Hispida, Michx.

Bristly Aralia.

Rocks and swamps. Littlefalls. Sides of the Black river. Abundant in the sandy swamp west of Fort Bull, Rome.

Frequent. June, July.

NUDICAULIS, $L$.

Woods, both high and low.

QUINQUEFOLIA, Gray.
Leafless-stemmed Aralia.

Common. May, June.

Ginseng. Five-leaved Aratia.

Ravines and thickets, where it has eluded the hunter; exhausted in many regions, but common in the remote woods. June, July.

TRIFOLIA, Gray.

Moist woods and their borders, in deep soil.

Groundnut. Three-leaved Aralia.

\section{CORNACE正。} Common. April, May.

Cornels.

CORNUS, Tournefort.

CANADENSIS, $L$.

Shaded sandy woods.

FLORIDA, $L$.

Dogwoods.

Dwarf Cornel. Conadian Cornus.

Common. May, June.

Flowering Cornus.

Hilly woods. Schenectady, along the Platte kill, Pearson. Otsego county, H. Lathrop. Banks along the outlet of Owasco lake, I. H. Hall. Abundant in Yates county, Sartwell. Monroe county, Bradley. Uncommon. May.

CiRCinata, L'Héritier.

Rounded-leaved Cornus.

Borders of woods and thickets near water. Pine woods of Schenectady county. Oneida county, Knieskern. Trenton falls, Hadley in herb. Alexandria bay, on the islands of the river.

Frequent. June.

SERICEA, L.

Silky Cornus.

Swamps and water-sides. Summit lake, Otsego county. About Onondaga lake. Alexandria bay. Lake marshes, Yates county, Sartwell. Infrequent. June.

Stolonifera, Michaux.

Wet flats of streams.

PANICULATA, L'Héritier.
Stolon-bearing Cornus.

Abundant. May, June.

Panicled Cornus.

Thickets along the sides of streams. Banks of the Mohawk.

Frequent. June, July.

ALTERNIFOLIA, $L$.

Open woods.

NYSSA, $L$.

MULTIFLORA, Wangenheim.

Occasional on the flats of the Mohawk. Borders of Otsego lake. Miss S.

Cooper. Near Vernon, Prof. O. Root. Near Oneida lake, Knieskern.

Infrequent. April, May. 


\section{B. MONOPETALOUS EXOGENS.}

CAPRIFOLIACE E.

Honeysuckles.

LINNÆA, Gronovius.

BOREALIS, Gronov.

Twin-flower.

Northern Linncea.

Shady banks and arbor-vitæ swamps. Common in all the cold marshes on the highlands south of the Mohawk, Summit lake, Mud lake, State swamp, Hidden lake. Little falls above the south cliff. Springy wooded slopes on the flats of the Mohawk between Frankfort and Utica. Ravine sides in Deerfield. and Marcy. Cedar swamp on Paris hill. Sides of the Black river below Watertown, in evergreen shade.

Frequent. June - August.

SYMPHORICARPUS, Dillenius.

RACEMOSUS, Michx.

Snowberry.

Rocky banks. Helderberg Prospect rock, Pearson. Otsego county, H. Lathrop. Along the Black river between Watertown and Dexter. Genesee falls, Carey in herb. Ham. Coll. Genesee river banks, Greece, Bradley.

Rare. June, July.

vUlgaris, Mich $x$.

Coral-berry. Common Symphoricarpus.

Borders of Seneca lake, Sartwell in herb. Ham. Coll. Occasionally admitted into gardens and ornamental grounds. July - September.

LONICERA, $L$.

Honeysuckles.

sempervirens, Aiton. Trumpet-honeysuckle. Evergreen Lonicera.

Banks near the river, Tarrytown and on the hills eastward, I. H. Hall. Thickets along the borders of Otsego lake, B. D. Gilbert : H. Lathrop.

Rare. June, July.

Grata, Aiton.

True Woodbine. Pleasant Lonicera.

Rocky hillsides. Otsego county, H. Lathrop. Shore of Lake Ontario, two miles northeast of Oswego.

Rare. May.

PARVIFLORA, Lamarck.

Small-flowered Lonicera.

Rocks and damp banks. Schenectady. Littlefalls. Swamps about Oriskany, Knieskern. Beyond Fort Bull, Rome. Along Wood creek. Rocky ravinesides of Fish creek. Borders of Onondaga lake. Rocky banks of the Black river.

Frequent. May.

HIRSUTA, Eaton.

Hairy Lonicera."

Rocks and shaded woods. Helderberg mountains, Pearson. Otsego county, Miss S. Cooper. Fairfield, Herkimer connty, Eaton bot. On the berm bank of the Erie canal about halfway between Oriskany and Rome, in low grounds, Knieskern. Rocky woods down the Black river below Watertown. Potter, Yates county, Sartwell.

Rare. July.

crliata, Muhl.

Ravine-sides and shady swamps.
Fly-honeysuckle. Ciliate-leaved Lonicera. Common. April, May.

CARULEA, $L$.

Mountain-honeysuckle. Blue-berried Lonicera.

Cold swamps. Near Vernon, J.S. Douglass; Knieskern. Phelps, Ontario county, Sartwell.

Rare. May, June.

oblongrfolia, Muhl. Suamp-honeysuchle. Oblong-leaved Lonicera.

Upland swamps on the range of hills south of the Mohawk valley. Headwaters of the Susquehanna river : abundant at Summit lake, Springfield, Otsego county; and at Mud lake, south Herkimer county. Headwaters of the Unadilla river : borders of Hidden lake, Litchfield, and the deep State marsh near Jerusalem corners.

Scarce, June. 
DIERVILLA, Tournefort.

TRIFIDA, Hoench.

Cliffs and ravine-sides.

TRIOSTEUM, $L$. PERFOLIATUM, $L$.

Bush-honeysuckle. Three-parted-peduncled Diervilla. Common, June, July.

Fever-wort.

Perfoliate Triosteum.

Shaded rocks and copses on deep soil. Little falls. Oneida county, Knieskern. Penn-Yan, Sartwell.

Uncommon. May - July.

SAMBUCUS, Tournefort.

CANADENSIS, $L$.

Roadsides, fences, neglected fields.

PUBENS, Mich $x$.

Borders of woods, thickets, ravines.

VIBURNUM, $L$.

NUDUM, $L$.

Swamps on the Mohawk flats.

[Arrow-woods. Viburna. Withe-wood. Naked-cymed Viburnum. Common. June.

LENTAGO, $L$.

Open woods and banks of streams.

Bending-branched Viburnum.

Abundant. May.

DENTATUM, $L$.

Arrow-wood. Toothed-leaved Viburnum.

Copses on the flats and banks of the Mohawk. Low lands about Onondaga lake.

Frequent. June.

Pubescens, Pursh.

Downy Viburnum.

Rocky banks of streams. Along the College brook, Schenectady, Pearson. Dexter, Jefferson county, Vasey. Borders of Crooked lake, Sartwell in herb. Ham. Coll. Banks of the Genesee below Rochester, C.M. Booth.

Rare. June.

ACERIFOLIUM, $L$.

Hilly woods.
Maple-leaved Viburnum. Common. May, June.

opduds, L. Cranberry-tree. Opulus, Poplar-leaved Viburnum.

River-banks. Shores of the Mohawk river, and in low grounds over the flats.

Abundant. June.

LAntanoides, Michaux. Hobblebush. Lantana, Wayfaring-tree-lihe Viburnum.

Damp, sandy or hilly woods. Frequent in ravines and abundant on the hills: Graefenberg hill, Paris hill. In full force in the North woods, of ten so completely covering the ground as to render the forests impassable. May, June.

\section{RUBIACE $\mathrm{E}$.}

Madders.

GALIUM, $L$.

APARINE, $L$.

Shaded swamps.

ASPRELLUM, Mich $x$.
Cleavers. Galia. The Ancient Aparine. Frequent. June.

Rough Galium. TRIFIDUM, $L$.

Three-parted-peduncled Galium.

Cold grassy and mossy swamps. Summit lake, Otsego county. Mud lake, Hidlen lake, and the State marsh, south Herkimer county. Spring bogs near Fish creek and Point of Rock.

Rare. 
var. тілстовігы, Torr. \& Gr.

Dyers Galium.

Marshes. Abundant.

var. LATIFOLICM, Torr.

Broad-lexved Galium.

Borders of marshes and streams. Uncommon.

June, July.

TRIFLORCM, Wichx.

Damp groves.

Fragrant-drying, Three-flowered Galium. Common. July.

PILostu, Aiton.

Hairy Galium.

Dry sandy plains near Oneida lade, Knieskern. Junius, Seneca county, Sartwell in herb. Ham. Coll.

CIRCAZANs, Michx.

Copses, borders of dry woods.

Scarce. June, July.

LANCEOLATCM, Torr.

Tooded banks.

Circcea-like Galium.

Frequent. June.

Lanceolate-leared Galium.

Uneommon. June, July.

BOREALE, $L$.

Northern Galium.

Clitfis, rncks rirer-3anks. Talles of the Mohamk from Schecetarly to Little-

falls. Fairfield, Hadley in herb. Banks of Oneida creek, Knieskern. Rocks of the Black rirer. Sometimes in swamps; Test-Bergen. Genesee county. Frequent. June - August.

CEPHALANTHUS, $L$. occidentalis, $L$.

Button-bush.

Western Cephalanthus.

Muddy swamps, borders of ponds, lakes. Abundant in the northeastern part of the State. Ifud lake, sonth Herkimer countr. Wohamk raller: Littlefalls; Below Ctica on the flats, around a pond; opposite Thitesboro, a siramp full. Black brook and Oneida lake. About Onondaga lake. Outlet of Orasco lake, I. H. Hall.

Abundant. July.

MITCHELLA, $L$.

REPENS, $L$.

Woods. moist and shady places.
Partridge-berry.

Creeping Mitchella. Common. June, July.
OLDENLANDIA, Plumier. purptrea, Gray.

var. LONGIFOLIA, Gray.

Bluets. Oldenlandias. Purple-flovered Oldenlandia. Long-leaved Oldenlandia. Rocks and dry soils. Otsego county. H. Lathrop. Rocky islands in Black river at Rntland, Jefferson county, $J$. G. Crocker. Gravelly sides of the river between Watertown and Sackett's-harbor.

Scarce. May, June.

var. ciltolati, Gray.

Fringed-leaved Oldenlandia. Grarelly hillsides along the shore of Lake Ontario. Sackett's-harbor and banks of Black river, Knieskern. Abundant on the hill-slopes around the Old Fort at Oswego. Genesee falls, Aiken in herb. Sartucll Hain. Coll. Rochester, C. Dewey.

May, June.

CARULEA, Gray.

Blue-flouered Oldenlandia.

Damp places on the banks of Black rirer. from Remsen, Hiss J.E.Johnson, to $\Pi$ atertown and Dexter. Otsego county, H. Lathrop. Mas - September. 


\section{VALERIANACEA.}

VALERIANA, Tournefort.

SYLVATICA, Banks.

Wrodland Valerian.

Very abundiant in a sphagnous swamp in Wayne county, near the shore of Lake Ontario, where it was discovered in 1833 by Dr. S.ARTwel., Gray in Rare plants of Northern and Western N.Y. Wayne county, Sartwell in herb. Hum. Coll. Common in all parts of the swamp in West-Bergen, northwestern Genesee county. At this station the flowers are pure white always, both in the open marsh and its shady borders.

Rare. June.

FEDIA, Goertner.

Corn Salad.

OLITORIA, VahI. Garden Fedia.

Cultivated grounds, roadsides. Scottsville, Monroe county, L. Holzer.

Rare. May,

FAGOPYRUM, Torr. \& Gr.

Buckiheat, Fagopyrum Fedia.

Mohawk flats near Utica, Gray. Borders of a long narrow mud-pond below the eity, on the north side of the river, once the bed of the stream.

Rare. May.

DIPSACE.E.

Teasels.

DIPSACUS, Tournefort.

SYLVESTRIS, Miller.

Roadsides.

FULLONUM, Miller.

Escaped from cultivation. Sehenectady, Pearson. Auburn and Skaneateles, I. H. Hall.

COMPOSITE,

Composites.

VERNONIA, Schreher.

NOVEBORACENSIS, Willd,

Iron-weed.

Ner-York Vernonia.

Low grounds and drained swamps. Tarrytown, I. H. Hall. Wayne county, Sartwell in herb. Hum. Coll.

Rare. August, September.

EUPATORIUM, Tournefort.

PURPEREUM, $L$.

Banks of streams; low thickets.

HYSSOPIFOLIUM, $L$.

TEUCRIFOLIUM, Willd.

Thoroughworts, Bonesets. Eupratoria. Purple Eupatorium.

Common. August.

Edges of low woods and swampy ground, near Tarrytown, I. H. Hall.

Rare. August.

SESSTLTFOLIUM, $L$.

Sessile-leaved Eupatorium,

Wooded banks. Oneida county, Gray in herb. Sartwell Ham. Coll.

Rare. August.

perfoliatri, L. Common Boneset. Connate-leaved Eupatorium.

Open swamps and grassy bottoms of ravines. Common. July, August.

AGERATOIDES, $L$.

Woods, streams,

Ageratum-like Eupatorium.

Common. August - October. 
MIKANIA, Willd.

Climbing Hemp-ureed. SCANDENS, $L$. Ascending Mikania.

Shaded swamps. Sleepy-hollow stream, Tarrytown, I.H.Hall. Low grounds near Oneida lake, Knieskern. Marshes around Onondaga lake.

Infrequent. July - September.

NARDOSMIA, Cassini.

PALMATA, Hoaker.

Sueet Coltsfoot.

Cold swamps. Vear Saratoga, Dr. Steele. Turrey \& Giot Fl Prof. Hitch rock, Tarrey Fl. N.Y. Dundee. X.Y., Wright in herb. Sartuell Hu n. Coll. Valley of the Genesee river between Rochester and Lalie Ontario, in a cleared swamp, C.M. Booth.

Rare. May.

TUSSILAGO, Tournefort.

Common Caltsfoot.

FARFARA, L. From the ancient Farfarus. River-side Tussilago.

Brooksides at the crossing of roads; flats of creeks; far up ravines in woods.

Common. April.

SERICOCARPUS, Nees von Esenbeck. conyzordes, Nees.

Copses, wooded hillsides.

ASTER, $L$.

Corymbosus, Aiton.

Borders of woods.

MACROPHYLLUS, $L$.

Damp shaded banks.

patens, Aiton.

Dry hillsides.

var. PHLOGIFOLIUS, Torr. $\& G r$.

Shaded hillsides. Common at Tarrytown, I.H.Hall. Schenectady, Pearson. Infrequent.

LAVIS, $L$.

Thickets. Banks of the east side of Onondaga lake.

Smooth Aster.

Occasional.

White-topped Aster. Conyza-like Sericocarpus. Infrequent. July, August.

Staruorts. Asters.

Corymbed Aster. Common. July, August.

Large-leaved Aster. Abundant. Aligust - October.

Spreading Aster. Frequent.

Phlox-leaved Aster. var. L Evigatus, Torr. $\& G r$.

Smooth-stemmed Aster.

Copses. Yates county, Sartwell in herb. Ham. Coll.

var. CYANEUS, Torr. \& Gr.

Frequent.

Azure Aster.

Open woods. Tarrytown, common, I. H. Hall. Penn-Tan. Sartwell in herb. Ham. Coll.

Abundant.

UNDULATUS, $L$.

Dry woodlands.

Wavy-leaved Aster. Commoñ.

CORDIFOLIUS, $L$.

Heart-leaved Aster.

Shaded hillsides.

Common.

SAGITTTFOLIUS, Willd.

Arrou-leaved Aster.

Open banks. Auburn, common, I. H. Hall. Yates county, Sartwell in herb. Ham. Coll.

Abundant.

ERICOIDES, $L$.

Heath-like Lister.

Roadsides; neglected, eleared land.
Common. 
MCLTIFLORES, Ailon.

Many-flowered Aster

Barren fields, dry hills,

Abundant.

DCMOsts, $L$.

Copses, banks, along water-courses.

Bushy, Aster.

Frequent.

TRADESCANTI, $L$.

Tradescant's Aster.

Streams and damp woods. Tarrytown, I. H. Hall. Schenectady, Pearson.

Abundant.

MISER, $L$.

Defucient-flowered Aster.

Thickets, waste-places.

Colnmon.

var. GLOMERELLUS, Torr. $\& G r$.

Yates county, Sartwell in herb. Ham. Coll.

Glomerate-spiked-flowered Aster.

var. DIfFusus, Torr. \& $G r$.

Diffuse-branched Aster.

Tates county, Sartwell in herb. Ham. Coll.

A depauperate form of this variety abounds on the cold wet cliffs of Fish creek.

var. HiRsuticaulis, Torr. \& Gr. Hirsute-stemmed Aster. Albany, Beck, Torrey \& Gray Fl. Wayne county, Sartwell, Torr. \& Gr. Fl. in herb. Ham. Coll.

STMPLEX, Willd.

Simple-stemmed Aster.

Ravines and shady swamps.

Often.

carneus, Nees von Esenbeck.

Flesh-colored Aster.

Low grounds Yates county, Sartwell in herb. Ham. Coll.

The old form A. GREeniI Torrey \& Gray, between North and South Colleges, Schenectady, Tuckerman, Pearson.

Rare.

LONGIFOLIUS, Lamarck.

Long-leaved Aster.

Low woods on islands in the Pocantico above Tarrytown, $I$. H. Hall. Jefferson county, Crawe in herb. Sartwell Ham. Coll.

Rare.

PUNICEUS, $L$.

Low grounds.

var. VIMINECs, Torr. \& Gr.

Deep woods and swamps.

PRENANTHOIDES, Muhl.
Purple-stemmed Aster. Common.

Slender-stemmed Aster. Frequent.

Prenanthes-like Aster.

Damp rich woods. Common in Oneida county, Gray. Western part of the State, Torrey \& Gr. Fl.; Knieskern and Sartwell, Torrey Fl.N.Y. Watertown, Crawe; Dundee, Yates county, Wright; Penn-Yan, Sartwell; in herb. Ham. Coll.

Abundant.

NOVA-ANGLIE, L.

Roadsides, streams, open swamps.

Acuminatus, Michx.

Rocks, ravines and hills, in moisture and shade.

PTARMICOIDES, Tor $r$ \& $G r$.
New-England Aster. Common. Acuminate-leaved Aster. Abundant.

Ptarmica-like Aster.

On the rocky banks of Black river, near Watertown, Jefferson county, where it is very abundant, and was first noticed by Dr. CRAWE, Gray in Rare plants of Northern N.Y. Rocky banks of the river at Watertown, near the bridge of the road to Dexter, Gray. Jefferson county. Crawe in herb. Ham. Coll. Banks of Genesee river below Rochester, C.M. Booth. Rare. August. 
ERIGERON, $L$.

Fleabanes.

CANADENSE, $L$.

Roadsides, waste places; a field weed.

Canadian Erigeron

BELLIDIFOLIUM, Muhl.

Rocky hillsides and edges of thickets. PHILADELPHICUM, $L$.

Borders of woods, swamps; wet rocks.

AnNoum, Persoon.

Waysides, waste-places.

strigosum, Muhl.

Neglected fields, poor meadows.

DIPLOPAPPUS, Cassini.

LINARIIFOLIUS, Hooker.

Rocky, gravelly or sandy soils. Schenectady, Pearson, Gray.

Common. July - September.

Daisy, Bellis-leaved Erigeron.

Infrequent. May.

Philadelphia Erigeron.

Common. June, July.

Annual Erigeron.

Common. June - August.

Hairy Erigeron.

Common June, July.

Double-bristled Asters.

Linaria-leaved Diplopappus.

Infrequent. August - October.

UMBELLATUS, Torr. \& Gr.

Umbelled Diplopappus.

Opeu swamps. Abundant, especially on the hills. August, September.

AMYGDALINUs, Torr. \& Gr.

Almond-leaved Diplopappus.

Marshes. Gorham, Ontario county, Sartwell. Dundee. Yates county, Wright, Vasey.

Rare. August.

CORNIFOLIUS, Darlington.

Cornus-leaved Diplopappus.

Open woods. Oswego, Knieskern in herb. Sartwell Ham. Coll.

Rare. July - September.

SOLIDAGO, L.

Goldenrods. sQUARrosa, Muhl.

Squarrose-involucred Solidago.

Dry rocky soil and woods. Abundant at Alexaudria bay, G.W. Clinton.

Penn-Yan, Sartwell. Mount Hope and banks of the Genesee below Rochester, C.M. Booth.

Rare.

BICOLOR, $L$.

Hillsides and barren sandy copses.

LATIFOLIA, $L$.

Shaded rocks and banks.

Silver-rod. Two-colored Solidago.

Abundant.

Broad-leaved Solidago.

Common.

C ESIA, $L$.

Wooded hills, thickets.

Gray-purple-stemmed Solidago.

Frequent.

PUBERULA, Nuttall.

Top of a high hill near Tarrytown, I. H. Hall.

Downy Solidago.

Rare.

STRICTA, Aiton.

Willow-leaved, Wand-like Solidago.

Sphagnum swamps. Oneida county, Gray, Torrey Fl. N.Y. Abundant in the swamp on Paris hill.

Rare. July.

SPECIOSA, Nuttall.

Showy Solidago.

var. ANGUStATA, Torr. \& Gr., or a depauperate form, on the sides and summit of Bald rock, near Third lake, north Herkimer county.

Rare. August.

ohioensis, Riddell.

Ohio Solidago.

Low lands. Yates county, Sartwell in herb. Ham. Coll. In various parts of Western N.Y., Knieskern, Sartwell, G.W.Clinton, Torr. \& Gr. Fl. Rare. 
Hodghtonit, Torrey \& Gray.

Discovered by Houghton.

Damp moss and marl longs of the swamp in West-Bergen, Genesee county; in company with a number of lake shore plants, Comandra livida, Juniperus sabina, Juncus balticus, Scirpus torreyi, and others.

Leave3 sheathing opposite sides of the stem at its base, rigid, narrow, ciliate, all clasping, two to six inches in length, deep green; stems slender, purple; heads large, rays sometimes spreading three-fourths of an inch, in a drooping corymb.. A peculiar and beautiful plant.

Rare. July.

NEGLECTA, Torr \& $G r$.

Unnoticed Solidago.

Marshes. Bethel, Ontario county, Sartwell in herb. Ham. Coll. Uncommon.

PATCLA, Muhl.

Swamps.

ARGUTA, Aiton.

Borders of woods and fields.

var. JUNCEA, Torr. \& Gr.

Schenectady, Pearson.

MUHLENBERGI, Torr $\&$ Gr.
Spreading Solidago. Common.

Sharp-serrated-leaved Solidago. Frequent.

Reed-like Solidago. Frequent.

Discovered by MuHLenberg.

Bogs, shaded wet bottoms. Schenectady, Pearson. Ponn-Yan, Sartwell in herb. Ham. Coll. Rare.

LINOIDES, Solander.

Linum-like Solidago.

Marshes, sphagnum swamps. Junius, Seneca county, Sartwell in herb.Ham. Coll.

Rare.

ALTISSIMA, $L$.

Along fences, bottoms of ravines.

ULMifolia, Muhl.

Thickets, river-sides.

ODORA, Aiton.

Open woods, hillsides. The earliest one in blossom, Knieskern. Rocky banks of Seneca lake, Vasey.

NEMORALIS, Aiton.

Barren soils.

Hoary Goldenrod. Woodland Solidago.

CANADENSIS, $L$.

Roadsides, fences. Everywhere without limit.

var. PROCERA, Torr. $\& G r$.

Walls, banks, hills.

SEROTINA, Aiton.

Ravine-sides and thickets along streams.

GIGANTEA, Aiton.

Meadow-fences, open bottoms of ravines.
High Solidago.

Common.

Frequent.
Elm-leaved Solidago.

Sueet Goldenrod. Fragrant Solidago. Uncommon.

Common.

Canadian Solidago.

Towering Solidago.

Common.

Late-flowering Solidago.

Frequent.

Giant Solidago.

Common.

LA NCEOLATA, $L$.

Bushy Goldenrod. Narrow-leaced Solidago.

Flats and banks of the Mohawk.

Abundant.

INULA, $L$.

Enula Campana. Common Elecampane.

HE LENIUM, L.

The Ancient Helenion.

Roadsides, extensively naturalized. July, August. 
POLYMNIA, $L$.

Leafcups.

CANADENSIS, $L$.

Canadian Polymnia.

Shaded rocky sides of streams. About Vernon, J. S. Douglass, Knieskern, Ravine of Chittenango creek, below the falls. Hackney falls, Owasen lake outlet, I. H. Hall. Gorham, Ontario county, Sartwell in herb. Ham. Coll.

Rare. July - September.

UVEDALIA, $L$.

In honor of RoBert UVEDALE.

Deep ravine of Chittenango creek, at the water side. Borders of Seneca lake, Sartwell in herb. Ham. Coll.

Rare. August, September.

AMBROSIA, Tournefort.

Ragueed. Wormuood. TRIFIDA, $L$. Three-parted-leaved Ambrosia.

Forming thickets along the banks of the Mohawk. Common. July, August.

ARTEMISI ÆFOLIA, $L$.

Waysides, waste places.

XANTHIUM, Tournefort. STRUMARIUM, $L$.

Artemisia-leaved Ambrosia. Common. July - September.

Cockleburs.

Struma-healing Xanthium.

Tards, streets, waste grounds. Abundant on the low banks of the Mohawk. Common. August.

SPIN OSUM, L.

Thorny Xanthium.

Around the Dexter factories, Knieskern. Hab. Oriskany, but rare, P.D.K. in herb. Sartwell Ham. Coll.

August - October.

HELIOPSIS, Persoon.

LEVIs, Pers.

Marshes and streams.

False Sunflower.

Smooth Heliopsis.

Conmon. August - October.

Coneflowers.

Deeply-parted-leaved Rudbeckia.

Common. July - September.

Bottoms of ravines, creeks, rivers.

FULGida, Aiton.

Meadows, occasionally, but not permanent.

HIRTA, $L$.

Pastures, meadows and their borders.

\section{HELIANTHUS, $L$.}

GIGANTEUS, $L$.

Fulgent Rudbeckia. July, August.

Rough Rudbeckia. Common. June, July.

Low river-banks and marshes of lakes. Frequent. August, September.

STRUMOSEs, $L$.

Thickets on hillsides and river-banks. var. MoLLIs, Torr. \& Gr.

Penn-Xan, Sartwell. Greece, sides of Genesee river, Bradley.

divaricatus, $\boldsymbol{l}$.

Open woods.

Tubercled-stemmed Helianthus.

Abundant.

Downy-leaved Helianthus. ECAPETALUS, $L$.

Ravine-sides and bottoms.

Divergent Helianthus. Common.

Ten-rayed Helianthus. Infrequent.

var. Frondosus, Torr. \& Gr. Leafy-involucred Helianthus. Shady stream-sides.

Uncommon. 
TUBEROSUS, L.

Artichoke. Tuberous Helianthus.

Walls and feuces.

Occasional.

ACTINOMERIS. Nuttall.

SQUARROSA, Nutt.

Actinomeris. tern New-York, Torrey \& Gray Fl.

Squarrose-involucred Actinomeris.

Borders of Crooked lake, Yates county, Sartwell in herb. Ham. Coll. Wes-

BIDENS, $L$.

FRONDOSA, $L$ 。

Bur-marigolds.

Walls, yards, waste places.

convata, Muhl.

Ditches, brooks.

Rare. August, September.

CERNUA, $L$.

Swamps.

Leafy Bidens.

Common. July-September.

Connate-leaved Bidens.

Uncommon.

Nodding Bidens.

Frequent.

ChrTsantheMotdes, Mich $x$.

Marshes, horders of streams.

Chrysanthemum-like Bidens.

Abundant.

вескі, Torrey.

Discovered by L. C. BEck.

Sander's lake, Scotia, where it was discovered by Dr. Brск, Peurson. Canaderaga lake, Miss S. Cooper: outlet of Schuyler's lake, Gray. Southern part of Oneida county Crawe, Knieskern. Ponds near Augusta, J. S. Douglass, Torrey Fl. N.Y. Oswego falls, Aiken in herb. Sartwell Ham. Coll. Sodus bay, Eaton bot. Rare. July, August.

BIPINNATA, $L$.

Bipinnate Bidens.

Bordering gardens and fields. Seneca lake, Sartwell.

Scarce.

HELENIUM, $L$.

AUTUMNALE, $L$.

Flats of brooks and creeks.

Helenium. Autumnal Helenium. Common. Septenaber.

MARUTA, Cassini.

Mayweed.

COTULA, DC.

Waste places, everywhere.

Cup-involucred Maruta.

June - September.

ANTHEMIS, $L$.

Camomile.

ARVENSIS, L.

Field Anthemis.

Cultivated land and neglected fields. Schenectady, Peurson. Saudy cleared grounds at the head of Oneida lake. Penn-Yan, Sartwell in herb.Ham.Coll.

Rare. June, July.

ACHILLEA, $L$.

Yarrow.

MILLEFOLIUM, $L$.

Milfoil Achillea.

Roadsides, pastures, barren hillsides. On the rocks of Little-fills probably, and along the cliffs of Fish creek doubtless it is native. In the latter habitat. it abounds over the precipices from clefts of rock, in moist soil of ledges and near dripping water or falling streams; far up the creek, for many miles among the woods, above any means of introduction.

Common.

var. Rosea. Penn-Tan, Sartwell in herb. Ham. Coll. June - September.

LEUCANTHEMUM, Tournefort.

VULGARE, Lamarck.

Oxeye Daisy.

Meadows, pastures, roadsides.

Common Whiteweed.

Common. June, July. 
TANACETUM, $L$.

Tansy.

$V U L G A R E$, L.

Common Tanacetum.

Way-sides, tences, in patches.

Common. July - September.

ARTEMISIA, $L$.

Wormwoods.

Canadensis, Michx.

Canadian Artemisia.

Sandy shores of lakes. Legit. Oneida county, Knieskern in herb. Sartwell Ham. Coll. Along Irondequoit bay, L. Holzer. Shore of Lake Ontario, Greece, Bradley.

Rare. July, Angust.

VULG.ARIS', L.

Roadsides in Verona, rare, Knieskern.

Mugwort. Common Artemisia.

August - November.

ABSINTHIUM, L.

Wormwood. The ancient Absinthion.

Roadsides. Naturalized in the northern part of the county, Knieskern. Waysides on the hills of Liichfield, east of Hidden lake. south Herkimer county.

Infrequent. August.

GNAPHALIUM, $L$.

DECURRENS, Ives.

Everlastings.

Old pastures, uncultivated cleared hills. Common. August-October.

POLYCEPHALUM, Mich $x$.

Many-headed Gnaphalium.

Sandy fields and open woods. Pine plains of Rome, Knieskern. Scbenectady, Pearson. Penn-Ian, Sartwell.

Uncommon.

ULIGINOSUM, $L$.

Roadsides, ditches, low grounds.

Bog Gnaphalium.

Common.

ANTENNARIA, Gartner.

MARGARITACEA, R. Brown.

Roadsides, pastures, copses.

Everlastings.

Pearly Antennaria.

Common. August.

plantaginifolia, Hooker.

Tops of ravine-banks, dry pastures.

Plantain-leaved Antennaria.

Common. April, May.

ERECHTHITES, Rafinesque.

HIERACIF OLIA, Raf.

Fireweed.

Damp woods, clearings; most common after fire. July - September.

CACALIA, $L$.

SUAVEOLENS, $L$.

Indian Plantains.

Fragrant Cacalia.

Woodlands. Penfield, Monroe county, banks of a stream emptying into Irondequoit bay, L. Holzer. Greece, Bradley. Avon, Livingston county, B. D. Greene, Torrey \& Gray $\mathrm{Fl}$.

ATRIPLICIFOLIA, $L$. Rare. August - October.

Deep woods. Genesee river, Sartwell in herb. Ham.Coll. Near Rochester, Z. H. Harris, Bradley.

Atriplex-leaved Cacalia. Rare. July - September.

SENECIO, $L$.

Groundsel.

VULGARIS, L.

Common Senecio.

Common on the Central railroad. Streets and gardens, Utica. Rochester. July - October.

AUREUS, $L$.

Golden Senecio.

Wet meadows, swampy woods.

Common. May.

[ON. PL.] 
var. obovatus, Torr. \& Gr.

Obovate-leaved Senecio.

SIrated steeps between the tup of the elifrs and the brow of the heights, at Littlefalls, south side of the Mohawk. Yates county, Sartwell.

Infrequent. June.

var. BALsAMit E, Torr. \& Gr.

Balsanita Senecio.

Rocky banks of Black river opposite and below Watertown, Jefferson county. Abundant in the swamp of West-Bergen, Genesee county, where the whole plant is often very woolly. Rare. June.

var, LANCEOLATUS, Oakes.

Long-leaved Senecio.

Bald rock near Third lake, north Herkimer eounty, in wet woods along its base. Rare. June, July.

CNICUS, Vaillant.

Blessed Thistle.

BENEDICTUS, L. Reputed Cnicus.

Roadsides and about houses. Schenectady, Pearson. Oneida county, Knieskern.

Rare. Jane.

CIRSIUM, Tournefort.

L.ANCEOLATUM, Scopoli.

Pastures, roadsides.

Discolor, Sprengel.
Common Thistles.

Lanceolate-leaved Cirsium. Common. June-September.

Two-colored Cirsium.

Borders of woods and fields. Schenectady, Pearson. Meadnws of the Mohawk between Littlefalls and Palatine bridge. Oneida county, Knieskern. Tates county, Surtwell in herb. Ham. Coll.

Infrequent. Augnst.

MUTICUM, Michx.

Swamps, marshes, springy hillsides.

PUMrud, Sprengel.
Awnless Cirsium.

Common. August - Oetober.

Dwarf Cirsium.

Old pastures, uncultivated sandy fields. Schenectady, Penrson. Otsego county, H. Lathrop. Yates county, Sartwell in herb. Ham. Coll.

Uncommon. July, August.

ARVENSE, Scopoli.

Canada Thistle. Field Cirsium.

Roadsides, cultivated fields. Common. Flowers white frequently.

July - September.

ONOPORDON, Vaillant.

ACANTHIUM, L.
Cotton Thistle.

The ancient Acanthion.

Waysides, rocky banks. Fairfield, Herkimer county, in herb. Hadley. About Rochester and toward the Lake, C.M.Booth. Scarce. July-September.

LAPPA, Tournefort.

Burdock.

$M . A J O R$, Gærtner.

Larger Lappa.

Waste places.

Common. July - October.

CICHORIUM, Tournefort.

INT YBUS, L.

Cichory.

The classical Intubus.

Roadsides. Abundant in West-Albany, along the Central railroad. Willow vale, New-Hartford. Verona, Knieskern. Scarce. July-October.

KRIGIA, Schreber. VIRGINICA, Willd.

Dry sandy fields near Oneida lake, Knieskern.
Dwarf Dandelion.

Virginian Krigia.

Rare. May - August. 


\section{HIERACIUM, Tournefort.}

CANADENSE, Michx.

Open hilly woods.

SCABRUM, Mich $x$.

Borders of thickets and fields.

GRONOVII, $L$.

Dry woods. Schenectady, Pearson. Near Oneida lake, Knieskern. Auburn, I. H. Hall.

venosum, $L$.

Veined-leaved Hieracium.

Sandy copses and evergreen woods. Schenectady. Common on the Pine plains of Rome. Abundant in Yates county, Sartwell. Greece, Bradley.

Frequent. June. July.

PANICULATUM, $L$.

Panicled Hieracium.

Copses, shady banks. Common at Schenectady, Pearson. Oneida county, Knieskern. North of Oswego on the Lake shore. Auburn, I. H. Hall. Yates county, Sartwell in herb. Ham. Coll. Greece. Monroe county, Bradley.

Abundant. August, September.

NABALUS, Cassini.

ALBUS, Hooker.

Woods.

Altissimus, Hooker.

Deep ravines.

var. CORDATUs, Torr. \& Gr.

Greece, Monroe county, Bradley.

var. DELTOIDEUs, Torr. \& Gr.

Rattlesnalie-roots.

White Nabalus.

Common. July, August.

Lofty Nabalus. Frequent.

Cordate-leaved Nabalus.

Deltoid-leaved Nabalus.

Penn-Yan, Yates county, Surtwell in herb. Ham. Coll. August, September.

TARAXACUM, Haller.

Dens-teonis, Desfontaines.

In all grass lands.

LACTUCA, Tournefort.

elongata, Muhl.

Open woods, thickets, along fences.

MULGEDIUM, Cassini.

LEUCOPH AUM, $D C$.

Moist woods, river-banks.

SONCHUS, $L$.

OLERACEUS, L.

Borders of cultivated grounds.

ASPE R, Villars.

Waste places, barnyards.

ARVENSIS, L.

Fields and water-sides. Oriskany, near the creek. Marshes on the west side of Onondaga lake. Waste fields, Auburn, I. H. Hall. Roadsides near Rochester, L. Holzer.
Dandelion.

Lion-tooth-leaved Taraxacum. April - October.

Wild Lettuce.

Long-panicled Lactuca. Common. July, August.

False Lettuce. Gray Mulgedium.

Frequent. August, September.

Garden Sonchus.

Common. July - September.

Spiny-leaved Sonchus.

Common. August, September.

Field Sonchus. 
IOBELIACEA.

Lobelias.

LOBELIA, L。

Lobelias.

CARDINALIS, $L$.

Boggy woode, water-sides.

Crimson, C'ardinal-flowered Lobelia.

Abundant. July, August.

SYPHILITICA, $L$.

Blue, Large-flowered Lobelia.

Damp grassy woods, swampy rivulets.

Abundant, August.

INFLATA, $L$.

Meadows, pastures.

sPICATA, Lamarck.

Hillsides and open woods.

KALMII, $L$.
Indian Tobacco. Inflated-fruited Lobelia. Common. July - September.

Spike-racemed Lobelia. Scarce. July, August.

KaLM's Lobetia.

Limestone rocks, marl swamps. Frequent on wet rocks in the cliffs above Trenton falls, where it oceurs in the regular form.

A larger plant, with all manner of variations, abounds in the imestone country south of Utiea, beyond the hills around Cedar lake, on Hidden lake, the State marsh near Jernsalem hill, and Mud lake, southeastern Iferkimer county.

Swamp at the foot of Owasco lake, I. H. Hall. Junius, Sartwell in herb. Ham. Coll. Banks of Genesee river, C.M.Booth. Rare. July-September.

DORTMANNA, $L$.

Water Lobelia. Dedicated to DoRTMans.

Sandy or gravelly bottoms along the borders of all the ponds and lakes in the north woods : abundant there.

Rare, July - September.

CAMPANULACEA.

CAMPANULA, Tournefort.

ROTUNDIFOLIA, $L$. Trenton falls. Fish creek precipices. Chittenango creek cliffs. It haca, Tompkins county, Sartwell in herb. Ham. Coll.

Abundant where it occurs. July - October.

AparinotDes, Pursh.

Galium, Aparine-like Campanula.

Grassy swamps and shores. Ballston lake, Pearson. Fairfield, in herb. Hadley. Oriskany thickets and swamps, Knieskern. Around Mud lake and the State marsh near Jerusalem hill, south Herkimer county. Near Crooked lake, Sartwell. Searce. July - September.

AMERICANA, $L$.

American Campanula.

Low rich woods. Chemung valley, Knieskern, Torrey $F l$ N.Y. In the vicinity of Seneca and Crooked lakes, Sartwell in herb. Han. Coll.

Rare. July - September.

SPECULARIA, Heister.

PERFoliata, $A . D C$.

Venus's Looking-glass.

Perfoliate Specularia.

Gravelly hills and banks. Schenectady, Pearson. Sandy fields near Oneida lake, Knieskern. Infrequent. May - July.

\section{ERICACE A:}

Heaths.

GAYLUSSACIA, H. B. $K$. RESINOSA, Torr. \& Gr.
Swamps, sands and rocks. Most abundant on the low sand plains of Rome, and the Thousand Islands of the St.Lawrence.
Frequent. May, June.

Whortleberries.

Resinous Gaylussacia. 
VACCINIUM, $L$. oxycocous, $L$.
Cranberries. Blueverrits. Small Cranberry. Tart-fruited Vaccinium.

Sphagnum swamps. Summit lake, Otsego county; Mud lake, Hidden lake, State marsh, Frankfort hill ponds, Herkimer county. Oriskany swamp; Paris hill; and abundant in the mossy marshes of the northwestern part of the county and the north woods.

Frequent. June.

Macrocarpon, Aiton. Common Cranberry. Large-fruited Vaccinium.

Cranberry swamps, margins of ponds. Mud lake, Graefenberg hill Hidden lake, south Herkimer county. Common in the Rome swamps; west of Fort Bull; head of Oneida lake.

Abundant. June, July.

STAMINEUM, $L$.

Deerberry. Long-stamened Vaccinium.

Borders of woods. Abundant in the dry plains and pine woods of Schenectady county. I have seen Oneida county specimens, but not growing. Knieskern. Frequent in Yates county, Sartwell.

Rare. June.

PENNSYLVANICUM, Lamarck.

Blueberry. Dwarf Vaccinium.

Sandy fields, hillsides and rocks. The most common species. May.

CANADENSE, Kalm.

Downy Vaccinium.

Cold cedar swamps. Mud lake, and the State marsh of Herkimer county. Bridgewater, Gray. Below Utica, in arbor-vitæ swamps on the flats of the Mohawk. Beyond Rome, on borders of deep sphagnum bogs. Rare. June.

VACILLANS, Solander.

Wavy-leaved Vaccinium.

Borders of sphagnum swales. At Rome, common in open woods and sandy plains.

Near Oriskany, Dr.Knieskern found a var. with small lanceolate-elliptical leaves, Torrey $\boldsymbol{F l}$. N.Y.

Infrequent. May.

CORYMBOSUM, $L$.

Corybmed Vaccinium.

Swamps and low open woods.

Common.

var. ATRococcum, Gray.

Blachi-fruited Vaccinium.

Borders of woods around bear pond on Frankfort hill. May, June.

CHIOGENES, Salisbury.

hispidula, Torr. \& Gr.

Creeping Snowberry.

Mossy swamps. under cedars and tamaracks; hut on the hills and in the northern part of the county, it abounds in the soil of woods and rocky banks.

Frequent. May.

CALLUNA, Salisbury. VULGARIS, Salisb.

Heath. Ling. Common Calluna.

Plants from Tewksbury, Mass., have been stationed on the sand plains of Rome; and in the north woods of Herkimer county, on a barren knoll in the beaver meadow beyond Bald rock, north of the Eight lakes, where they ought to flourish and multiply.

July - November.

\section{ARCTOSTAPHYLOS, Adanson.}

\section{UVA-URSI, Sprengel.}

Bearberry.

Sandy plains between Albany and Schenectady, H. Seymour. Dry sandy hills, pine plains north of New-London, Knieskern. Near Oneida lake, Gray. On the Thousand islands of the St.Lawrence at Alexandria bay. 
EPIG, IA, $L$.

Traiting Arbutus.

REPENS, $L$.

Creeping Epigå.

Saudy banks and open woods. Between Albany and Schenectady. Otsego county, Miss S. Cooper:B.D. Gilbert. Common on the sands of Rome, completely corering linolls in the swamps, and abundant throughout the dry pine plains. Northern Oneida and Lewis counties, H. Seymour.

Frequent. April, May.

GAULTHERIA, Kalm.

PROCUMBENS, $L$.

Sandy woods, swamps, banks.

Wintergreen. Cresping Gaultheria.

Common. July.

CASSANDRA, Don.

calyculata, Don.

Peat bogs, borders of ponds.

Leatherleaf. Bracted-calyxed Cassandra. Abundant. April.

ANDROMEDA, $L$. POLIFOLIA, $L$.

Andromedas.

Polium-leaved Andromeda.

Sphaguum swamps. Bogs in the sand plains and on the Rotterdam hills of Schenectady county. Summit lake, Otsego county. Mud lake, State marsh, Hidden lake, Frankfort and Graefenberg hills, Herkimer county. SouthTrenton; Paris hill; bogs on the pine plains of Rome; around Point of Rock lake. Abundant in the lake marshes of the north woods. Frequent May.

Ligustrina, Muhlenberg.

Ligustrum-like Andromeda.

Low grounds, borders of woods. A mile or two northeast of Schenectady, and abundant in bushy swamps on the Rotterdam hills. Southern counties, Knieskern in herb. Sartwell Ham. Coll.

Rare. July.

KALMIA, $L$.

LATIFOLIA, $L$.

American Laurels.

Broad-leaved Kalm:a.

Rocky hilisides near Leatherstocking's Cave, east of Otsego lake, Misses Bowen. Arbor-vita swamps on the flats of the Mohawk, between Utica and Frankfort; southwest of Utica, near the Chenango canal. Near Oriskany, Knieskern. Head of Crooked lake. Sartwell. Ithaca, Tompkins county, Bradley. Rare. June.

ANGUSTIFOLIA, $L$.

\section{Narrow-leaved Kalmia.}

Sandy plains and swamps. Schenectady, Pcarson. Oriskany, Knieskern. Abundant throughoet the plains of Rome. Junius, Seneca county, Sartwell in herb. Ham. Coll. Ithaca, Tompkins county, Bradley.

Frequent. June, July.

GLAuCA, Aiton.

Glaucons-leaved Kalmia.

Sphagnum swamps and lake marshes. Charlton, Schenectady county, Jackson. Otsego county, H.Lathrop. South-Trenton. Oriskany swamp formerly, Gray. A bundant in the open swamps of Rome. Level mossy border around Point of Rock lake, northwestern part of the county. Northeastern Oneida county, H. Seymour. Common in the low borders of ponds and lakes in the north woods.

Rare. May.

AZALEA, $L$.

Wild Azaleas. VISCOSA, $L$. Clammy Azalea.

Borders of low woods, bushy swamps. Halfway between Schenectady and Albany, Pearson. Near Boonville, Knieskern. Rare. June. 
NUDJFLORA, $L$.

Leafless-flowering Azalea.

Swamps and their borders; moods and drr hillsides. Rotterdam hills. Schenectady county. Otsego county, Miss $\boldsymbol{S}$. Cooper. Frankfort and Graefenberg swamps. Whitesboro, J.S. Gurdner. Common in southern One:da county and southward, Gray. Around the South-Trenton sphagnum swale. Abindant in the low plains of Rome. Rocky banks of the Black river below Watertown.

Abuudant. May.

RHODODENDRON, $L$.

MAXIMLM, $L$.

Mountain Laurel.

Greatest Rhododendron.

Swamps, sides of streams. Mohawk valley, Schenectady, Pearson : west of Oriskany, Vasey. Oriskany valley, a mile or two southeast of Clark's mills. Unadilla valley, four miles below Brıdgewater, Gray. Italy hill. Yates county, sartwell.

Rare. July.

\section{LEDUM, $L$.}

LATIFOLIUM, Aiton.

Labrador Tea.

Broad-leaved Ledum.

Swamps on the hills. Cedar swamp adjoining Mud lake; around Tetmore's sphagtum pond, Frankfort hill, Herkimer county. Abundant in the Paris hill swamp. Wooded swamps beyond Rome. Common in the north woods, at the edges of ponds, lakes, and far up their banks into the forests.

Scarce. May.

PYROLA, $L$.

ROTUNDIFOLIA, $L$.

Pyrolas.

Rich woods.

Round-leaved Pyrola.

Common. June, July.

var. AsARIFOLIA, Torr. \&. Gr.

Asarum-leaved Pyrola. Sandy hills. Near Utica. Yates county, Sartwell.

Infrequent.

ULiginosa, Torr. \& Gr.

Swamp Pyrola.

Cold swamps. Very abundant in the marshes near Summit lake at the top of the hill south of the Mohawk, source of Otsquago creek and the Susquehanna river; where it often covers the surface in patches. Abundant also at Mud lake, south Herkimer county, in shade and wet moss. Sparingly in the Litchfield marshes. Formerly it flourished in the Oriskany swamp, where it was discovered. Leaves orbiculate, on long petioles; flowers many, loose in the raceme, deep purple, the most beautiful of the genus. Rare. June.

Elliptica, Nutt.

Woods.

\section{CHLORANTHA, Swartz.}

Sandr woods. Schenectads county pine woods, and along the Rolle-boom of the Rotterdam hills. East side of Otsego lake, B.D.Gilbert. Plains of Rome, Knieskern. Penn-Jan, Sartwell in herb. Ham. Coll.

Rare. June.

\section{SECUNDA, $L$.}

Onesided-flowering Pyrola.

Dry woods and hillsides, in deep shade.

Common.

In the high cold cedar swamps of Summit lake; Mud lake. State swamp of south Herkimer countr, a small form grows in wet moss under erergreens, mith small round leares. half an inch in diameter and less, nearly entire, rery light-colored; flowers few, slender. Rare. July.

MONESES, Salisbury.

UNiFlora, Gray.

One-flowered Pyrola. Single-flowered Moneses.

Deep roods. Otsego county, Miss S. Cooper: J.S. Douglass, Torr.Fl.1.Y. Wonds at Herkimer, Gray. Eaton, Madison county, Bradley. Penn-Ian, Yates county, Sartwell in herb. Ham. Coll. 
CHIMAPHILA, Pursh.

uMBELATA, Nuttall.

Dry banks, in evergreen shade.

Prince's-pine.

Umbellate Chimaphila.

Common. June.

MACUlata, Pursh.

Sputted-leaved Chimaphila.

Sandy woods. Otsego county, common, Miss S. Cooper. Pine plains of

Rome, scarce. Near Verona, Knieskern. Auburn, I. H. Hall. Yates county, sartwell.

Usually with ovate leaves : lanceolate leaves are fuund in a cedar swamp solithwest of Utica, on the Chenargo canal.

Rare. July.

PTEROSPORA, Nuttall.

AndromedeA, Nutt.

Pine-drops.

Dry shaded banks. Factory glen, and Jantepusche's berg, Rotterdam, six miles west of Schenectady, Pearson. Steep sides of Oriskany creek just above Dexter factory, where it was discovered by VASEY. Litulefalls, Cooper; Sackett's-harbor, Wood; Banks of Seneca lake, Gray; Torrey Fl. N.Y. Penn-Yan, Sartwell in herb. Ham. Coll.

Rare. August.

MONOTROPA, $L$.

UNIFLORA, $L$ 。

Indian Pipe.

Dry woods.

HYPOPITYS, $L$.

Common. July, August.

Open woods of oak and pine. Helderberg monntains, three miles southeust of Knowerville, Pearson. Near Moss pond, Otsego county, B.D. Gilbert. Moist woods near Oneida lake, Knieskern. Yates county, Sartwell. Parma, Monroe county, Bradley.

Scarce, July, Angust.

\section{AQUIFOLIACEA.}

Hollies.

ILEX, $L$.

verticillata, Gray.

Streams and swamps.

LEVIGATA, Gray.

Low thickets. Major Van Voost's fly, Schenectady, Pearson.

Infrequent. June.

NEMOPAN'THES, Rafinesque.

CANADENSIS, $D C$.

Mountain Holly.

Canadian Nemopanthes.

Cold swamps. Frankfort hill, around the sphagnum pond. Paris hill. Abundant in the swamps west of Rome. Dry woods along the summit of the Fish creek eliffs. Common in the north woods about ponds and lakes.

Frequent. May.

\section{PLANTAGINACE E.}

Plantains.

PLANTAGO, L.

$M A J O R, \mathrm{~L}$.

Common Plantain. Greater Plantago.

Damp grounds, waste places.

June - August.

LANCEOLATA.L. English Plantain. Lanceolate-leaved Plantago. Roadsides and fields. 


\section{PRIIULA, $L$.}

MISTASSINICA, Michıux.

From Lake Mistassinnie.

Clitis of Fisl creek, from Taberg northmard; in the crevices of dry recks and on the surface of wet precipices, with, but outnumbering, suxifrugu aizoides. Near dripping water the plants grow must abuudantly and largesi, otten eight or ten inches in height. and bearing a cluster ot as many flowers. These vary in color, from pure white. through ditferent shades of pink, to deep bluc. The leaves also vary in form, from round obovate to oblong lanceolate; of ten entire, commouly nore or less toothed; usually smooth beneath, but frequently white mealy. A whsle cliff-side scattered over with these rariegated Primroses is one of the loreliest sights in all onr flura.

It has been found also in the deep ravine of Hammondsport at the head of Cruoked lake, Steuben county, by Dr. SARTrisL. 'These stations are the southerlimits of the plant. In the northern part of the contisent its range is extensive, from Labrador and Lake Mistassimuie, to the Rocky mountains and the Northwest coast; and northward to the Aretic circle.

Lucal. Latter part of May.

DODECATHEON, $L$.

MEADIA, $L$.
American Coustip. MEAD's Dodecatheon.

Rich banks. Steuben counly, Sartwell in herb. Ham. Coll. Rer. Mir. BostWICK, formerly of Hammondsport, found this on the Conhocton river below Bath, and introduced it to his garden, from which I collecied specimens, Sartuell. Rare. May.

TRIENTALIS, $L$. Americaya, Pursh.

Moist rocds.

LYSIMACHIA, $L$. stricta, Aiton.

Marshy places.

QLADRIF OLIA, $L$.

Opan sandy wools; wat grass lands.

CILIAA, $L$.
May-star. American Trientalis. Common. Miay.

Loosestrifes. Upright Lysimachia. Junc, July.

Wharled-leaved Lysimachia. Abunlant. June.

Fringed Lysimachia.

Borders of streams, stramps Common on the shaded banks of the Nohawk, in deep low woors, and cedar swamps on the hills.

\section{NALMBURGIA, Monch.}

THYRSIFLORA, R Richenbach.

Low meadows of the Mohawk. bolow Ctica, below Oriskany. Swamps on the liils, from Srummit lake to Cedar lake and Graefenberg hili. Paris hill. Abundant in the stramps of Rome. Frequent. Juue.

SAMOLUS, $L$.

VALERANd, L., var. AMeridẫus, Gray.
Water Pimpernel.

American Samolus.

Rivulet-sides, grassy marshes. Oriskany valley; Oriskany; Manchester. Abundant about Ouondaga lake, along muddy banks, especially at its head, Salina.

Infirequent. Juiy - September.

HOTTONIA, $L$.

Featherfoil. INFLATA, Elliott. Inflated-peduncled Hottonia.

Still water. Two or three miles west of Daxter, Jefferson county, Vasey. 
LENTIBULACEA.

Bladderworts.

UTRICULARIA, $L$.

Utricularias.

VULGARIS, $L$.

Common Ctricularia.

Ponds and their muddy borders. Below Utica. on the flats. Mnd lake and Hidden lake. south Iferkimer county. Bogs on the meadows of Fish creek above Humaston's. Black brook at the hearl of Oneida lake. Pouds near Oneida lake, Knieslern.

Abundant. Jun:, July.

MINoR, $L$.

Smaller Utricularia.

Swamps, Jefferson county, Crawe, Gruy in Rare plants of Northern N.Y. Abundant on Hidden lake, among grass in standing water, or along borders of wide places in the rivulet. Scapes ten- to fiften-flowered: flowers pale yellow, or flesh-colored.

Rare. June, July.

CLANDESTINA, Nutt.

Stem-flowering Utricularia.

Pond borders. I have another species of Utricularia, collected near Utica by Dr. KNIESERN, which I am nuable to determine fiom the dried and rather imperfect specimens. Its general appearance is that of $U$. vulgaris, but the flowers are scarcely one-third as large as in that species. The spur is short. thick, and very obtuse. At the base of the scape, and along the submerged stem, there are scattered one-tlowered peduncles, Torrey $F l N . Y$. In a shallow mossy pool on the sphagnum border of Wetmore's pond, Frankfort hill, a fit plants.

Rare. July.

\section{INTERMEDIA, Hayne.}

Intermediace Utricularia.

In very wet swamps, Watertown, Jefferson county, Crawe, Gray in Rare plants of Northern N.Y. Jefferson county, Crawe in herb. Sartwell Ham. Coll. Wet places on Hidden lake, Litchfield, south Herkimer county. where it is abundant.

Rare. June, July.

GIBBA, $L$.

In mossy sloughs on Hidden lake. Houghton in herb., G.W. Clinton.

CORNuTA, Michx.
Gibbous-spurred Utricularia.

Swamp west of Whitesboro, Douglass Rare. August.

Horned Ctricularia.

Swamps, bogs. shores. Abundant on Hidden lake in wet moss. Sphagnous swamp bordering Perch lake, Jefferson county, Giay in Rare plants of Northern $N . Y$. Frequent on sandy shores of lakes in the north woods. Swamps on the Pine plains of Rome, Knieskern. Junius, Seneca county, Surtwell in herb. Hain. Coll. Rare. June, July.

PINGUICULA, $L$.

Butterwort.

VULGARIS, $L$.

Common Butterwort.

Wet meadows below the falls of Genesee river at Rochester, Dewey in herb. Union Coll.; Carey in herb. Sartwell Ham. Coll.; Z. H. Harris in herb. Bradley. Exhausted at Rochester, but said to grow on the walls of the river above or below Portage, Chester Dewey.

Rare. June, July.

\section{OROBANCHACE E.}

Broomrapes.

EPIPHEGUS, Nuttall.

VIRGINIANA, Barton.

Beechdrops.

Everywhere in beech woods. The whole plant in color pure golden vellow, in rich woods near Clark's mills.

Angust, September.

CONOPHOLIS, Wallroth.

AMERICANA, Wallr.

American Conophisis.

Rich woods. Schoharie county, Knieskern: Oriskany, Vasey, Torr.Fl.N.Y. Chestnut woods east of Auburn, I. H.Hall. Seneca county, Sartwell in herb. Hum. Coll. Oak openings, Parma, Monroe county, Bradley. Rare. Juue. 
APHYLLON, Mitchell.

UNIFLORCM, Torr. \& Gr.

Single-flowered Aphyllon.

Moist woods. Schenectady, Pearson. Shady banks of the Mohawk. J. G.

Crocker. Pine plains of Rome, Knieskern.

Infrequent. May, June.

SCROPHULARIACEZS.

Figworts.

VERBASCUM, $L$.

Mulleins.

TH.APSLS, L.

Common Iullein. From the Ancient Thapsus.

Ruadsides, old fields.

Common. June, September.

$B L A T T A R I . A$, L.

Moth Mullein.

Waysides, pastures, hills. Albany; Schenectady; Littlefalls; round about

Ltica : the form with white and purple flowers. The bright yellow flowers are abundant in Trenton.

Common. June - October.

LYCHNITIS, L.

White Mullein. The Ancient Lychnitis.

Barren sandy fields and copses on a rilge at the head of Oneida lake, parallel with the shore, beyond which are swamps. It is most abundant around the mouth of Fish creek Here are the ruins of an old fort, which may account for the introduction of the plant.

Two hybrids between this species and $V$. thapsus. one resembling the latter with a simple stem and yellow flowers, and the other the former with paniculate branches and white corollas, were observed by Knieskern.

Local. July, Angust.

LINARIA, Tournefort.

Toadfax.

VULG.ARIS, Miller.

Roadsides and waste grounds.

Common Linaria.

Common. June - October.

ELATINE, Miller.

The Ancient Elatine.

Sandy soils. Near Albany, Beck; and shores of Cayuga lake, Gray, Torrey Fl. N.Y. Formerly in the streets of Geneva, Sartwell. Rare. June, July.

SCROPHULARIA, Tournefort.

NoDOSA, $L$.

Figwort.

Roadsides, river-banks.

Nodose-rooted Scrophularia.

Common. July - September.

COLLINSIA, Nuttall.

verna, Nutt.

Collinsia.

Early Collinsia.

Wet meadows on the flats of the Mohawk, just below Utica. Borders of a small pond near Utica, Knieskern. Near Utica, Gray; Ithaca, Aikin, Torrey Fl. N.Y.

Rare. May.

CHELONE, Tournefort.

Snakehead.

GLABRA, $L$.

Smooth Chelone.

Grassy swamps.

Common. July - October.

PENTSTEMON, Mitchell.

PUbESCENS, Solander.

Downy Pentstemon.

Barren gravelly banks. Abundant along the Railroad rest of Schenectadr to Fort-Plain. Otsego county, H. Lathrop. Rocky sides of Black river below Watertown. Seneca lake, Gray. Greece, on oak openings, Bradley.

Frequent. June - August.

MIMULUS, $L$.

RINGENS, $L$.

Ditches, streams.
Monkey-flowers.

Gaping-flowered Mimulus. Common. July - September. 
alatus, Aiton.

Winged-stemmed Mimulus.

Wet meadows, river-sides. Abundant in the western part of New-York, Beck. Grecee, Monroe county, Brudley. Lockport, sartwell.

Infrequent. July, August.

GRATIOLA, $L$.

VIRGINIANA, $L$.

Hedge-hyssop.

Muddy banks, rivulets and overflowed places. Common. June-August.

IJ. YS INTHES, Rafinesque.

False Pimpernel.

GRATIOLOIDES, Bentham.

Gratiola-like Ilysanthes.

Water-sides. Near Oneida lake, Knieskcrn, Gray. Infrequent. July-Sept.

VERONICA, $L$.

Speedwells.

VIRGINICA, $L$.

Culver's-root. Virginian Veronica.

Bolders of low woods, copses. Below Schenectady, Pearson. Clinton, Bradley. Oriskany, Knieskern. Junius and Avon, Sartuell in herb. Harn. Coll.

Infrequent. July.

ANAGALLIS, $L$.

Pcor Man's Weatherglass-tike Vercnica.

Rivulets and ponds. Abundant about Cedarville, and down the Ilion creek to the Mohawk river : grows to an immense size in the mill-ponds, in deep water.

Uncommon. June - August.

AMERICANA, Schweinitz.

Streams, marshes.

SCUTELLATA, $L$.

Wet meadows, swamps.

OFFICINALIS, $L$.

Dry woods, hillsides, pastures.

SERPYLLIFOLIA, $L$.

Moist grass lands.

PEREGRINA, $L$.

Rocks, gardens, fields.

ARVENSIS, L.

Dry banks, hillsides, pastures.

BUCHNERA, $L$.

AMERICANA, $L$.
American Veronica. Common. June - September.

Little Shield-like-podded Veronica. Common. May - July.

Officinal Veronica. Common. June.

Thyme-leaved Veronica. Common. May - August.

Travelling Veronica. Common. May, June.

Cultivated-field Veronica.

Frequent. April - August. Gurher Harris in herb. Bradley. Banks of the Genesce river, Grecee, Bradley, Torrey Fl. N.Y.

Rare. July, August.

\section{GERARDIA, $L$.}

PURPUREA, $L$.
Foxgloves. Gerardias. Purple-flowered Gerardia.

Marshy water-sides. Shores of Lake Ontario and the St.Lawrence river, from Irondequoit bay, L. Holzer, to Alexandria bay. Rare. July-Sept.

TENUIFOLIA, Vahl.

Slender-leaved Gerardia.

Dry barks. Chenango valley and westward, Knieskern. Copses along the east side of Onondaga lake. Crooked lake, Sartwell in herb. Ham. Coll. Oak openings, Greece, Bradley.

Frequent. August, September. 
FLAVA, $L$.

Yellow-flowered Gerardia.

Copses. Otsego county, H. Lathrop. Borders of Oneida lake. on sandy plains, Knieskern.

Occasional. July, August.

Quercifolia, Pursh.

Oak-leaved Gerardia.

Rocky woods; shady banks. Schenectady county, grove northeast of the College buildings, and copses on the Rutterdam hills. Near Oneida lake, Gray. Outlet of Owasco take, I. H. Hull. Yates county, Sartwell in herb. Ham. Coll. Gresce, on vak openiags, Bradley.

Scarce. August.

PEDICULARIA, L.

Pedicularis-leaved Gerardia.

Open woods. Pine plains of Schenectady, $E . W$. Puige. Ottlet of Owaseo

lake, I. H. Hall. Tates county, Sartwell in herb. Ham.Coll. Monroe county,

L. Holzer. Infrequent. August, September.

CASTILLEIA, Mutis.

Coccinea, Spreng.

Painted-cup.

Wet mead wrs, swamp borders. Oneida lote-

Wret meadows, swamp borders. Oneida lake, Gray. Katon, Madison connty,

Bradley. Penu-Yan, Sartweli in herb. Ham. Coll Greece, Monroe county, Bradley.

Infrequent. May, June.

SCHWALBEA, Gronovius.

AMERICANA, $L$.

Chaff-seed. American Schwalbea.

Sandy banks. Found in the sandy plains near Albany, Beck bot. Between Albany and Schenectady, near Centre station. Rare. June - August.

PEDICULARIS, Tournefort.

CANADENSIS, $L$.

Wood Betony.

Rocky woods. Little falls. Fish creek.

lanceOlata, Michx.

Lanceolate-leaved Pedicularis.

Borders of swamps. Tarrytown, I. H. Hall. Glenville, Schenectady county; Madison connty, Pearson. About Rochester, in several localities. C. M. Booth. Western counties, Knieskern. Rare. August, September.

MELAMPYRUM, Tournefort.

americanum, Michx.

American Melampyrum.

Diy woods. Rotterdam hills, Schenectady county. Aunndant in the rocky woods of Littlefalls, Herkimer county. Pine plains of Rome.

Frequent. June - August.

\section{ACANTHACE E.}

Acanthus.

DIANTHERA, Gronovius.

AMERICANA, $L$.

Water-willow.

Water-sides. Shallow water, Oneida lake, Knieskern. A mile or two south of Oswego, between the canal and the river. Scarce. July-September.

\section{VERBENACE $\nexists$.}

VERBENA, $L$.

\section{HASTATA, $L$.}

Waste grounds, flats of streams.

\section{URTICIEOLIA, $L$.}

Roadsides, pastures.

Hybrids with purple flowers are abundant.
Verbenas.

Vervains.

Hastate-leaved Verbena.

Common. July - September.

Nettle-leaved Verbena.

Common.

July - September. 
PHRYMA, $L$.

Lopseed.

LEPTOSTACHYA, $L$.

Ravines and borders of woods.

Slender-spiked Phryma.

Common. July, August.

\section{LABLATE.}

Mints.

TEUCRIUM, $L$.

CANADENSE, $L$.

Germander. Wood-sage.

Canadian Teucrium.

Banks of streams, marshes. Schenectady, Pearson. Banks of Fish creek, Knieskern. Ravine of Chittenango creek; borders of Onondaga lake. Island in the outlet of Owasco lake, I H. Hall. Head of Seneca lake, with white flowers, Sartwell in herb. Ham.Coll. Infrequent. July-September.

TRICHOSTENA, $L$. DIснотомим, $L$.

Blue Curls.

Rocks or barren hillsides. Littlefalls, sonth of the river, along the base of the eliffs.

Scarce. July, August.

ISANTHUS, Michaux

False Pennyroyal.

CERULEUS, Michx. Blue-flovered Isanthus.

River banks. Above Cohoes falls. Gray. Banks of the Erie canal between Albany and Schenectady, Knieshern; Jefferson county, Crawe, Torrey Fl. N.Y.

Rare. July, August.

NENTHA, $L$.

Mints.

VIRIDIS, L.

Brooks, roadsides in damp places.

Spearmint.

Common. July, August.

PIPERITA, L.

Rivulets and their borders.

Peppermint.

Abundant. July, August.

CANADENSIS, $L$.

Canadian Mint.

Low grounds. Common.

var. GLABRAta, Bentham.

Grassy swamps.

Smooth Mint.

Abundant. July, August.

LPCOPUS, $L$.

VIRGINICUS, $L$.

Shaded low grounds.

EUROPEUS, $L$.

$$
\text { var. SINUATUS, Gray. }
$$

Overflowed marshes, standing water.

HYSSOPUS, $L$.

OF FICIN.ALIS, L.
Bugle-weed. Water Horehounds.

Virginian Lycopus.

Frequent. July, August.

European Lycopus.

Sinuated-leaved Lycopus.

Common. July, August.

Hyssop.

Officinal Hyssopus.

Escapes from cultivation. Roadsides on the Litchfield hills, long established. Yates county, frequently, Sartwell

June - September.

PYCNANTHEMUM, Michaux.

Mountain-mints.

INCANUM, Michx. Hoary Pycnanthemum.

Rocks and hillsides. Oneida county, Knieskern. Yates county, Sartwell in herb. Hum. Coll. Greece, Mourve county, Bradley. Frequent. July, August. 
CLINOPODIOIDEs, Torr. \& Gr.

Clinopodium-lite Pycnanthemum.

Dry banks. Sleepy Hollow Cemetery, Tarrytown, I. H. Hall.

Scarce. Angust, September.

Mcticur, Persoon.

Awnless Pycnanthemum.

Barren hillsides. Tarrytown, I.H.Hall. Brighton, Monroe county. L.Holzer. Rare. July, August.

LANCeOlated, Pursh.

Lance-leaved Pycnanthemum.

Bushy banks along the east side of Onondaga lake. Greece. Monroe county, Bradley.

Infrequent. August, September.

ORIGANUM, $L$.

Wild Marjoram.

VULGARE, L.

Common Origanum.

Sandy or gravelly banks. Troy, Aiken in herb. Sartwell Ham. Coll.

Kare. July - October.

THYMLS, $L$.

Creeping Thyme.

SERPYLLUM. L.

The Ancient Serpyllum.

Banks. Hackney falls on the outlet of Owasco lake, Auburn, certainly wild, I. H. Hull.

Rare. June, Augist.

CALAMINTHA, Monch.

CLINOPODIUM, Bentham.

Copses.

MELISSA, $L$.

OFFICIN.ALIS, L.
Calaminth. Basil.

Bed-foot Calamintha. Common. July - September.

Roadsides edres of woods, remote from gardens. Fairfeld, Hadley in herb. Roadsides on the Litchfield hills. Woods near Schnyler, Herkimer county, on the hillside. East of Clintun.

Frequent. July - September.

HEDEOMA, Persoon.

PULEGIOIDES, Pers.

Pennyroyal.

Rich woods; barren sidehills and pastures. Common. July-Septenber.

COLLINSONIA, L.

CANADENSIS, $L$.

Shady ravine-bottoms.

MONARDA, $L$.

DIDYMA, $L$.

Wet meadows and ravines.

FISTULOSA, $L$.

Rocky banks. Penn-Yan, Sartwell in herb. Ham. Coll. Abundant near Rochester, Beck bot.

Iufrequent. July, August.

PUNCTATA, $L$.

Spotted-flowered Monarda.

Dry grounds. Jefferson county, Vasey; near Orego, Susquehanna valley, Krieskern, Torrey Fl.N.Y.

BLEPHILIA, Rafinesque.

Hirstta, Bentham.
Blephitia.

Hairy Blephilia.

Low woodlands. Abundant throughout the northern and western portions of the State, Gray in Rare plants of Northern N.Y. Fairfield, Herkimer county, Hadley, Gray. Richfield, Otsego county, G. W. Clinton. Bridgewater, Gray in cat.

Frequent. July, August. 
LOPHANTHUS, Bentham.

NEPETOIDEs, Benth.

Giant Hyssop.

Nepeta-like Lophanthus.

Thickets. Westport. Essex county, G. T. Stephens. Schencetariy county, E. Wr. Puige. Fairfiuld, Hadley in herb. Oneida county, Kinieskern. Near Bridgewater, Gray in cat.

Uncommon. July; August.

Scropituarifolis, Benth. Scrophularia-leared Lophanthus.

Borders of woods. Yates county, Sartwell in herb. Ham. Coll.

Scarce. Angust.

NEPETA, $L$.

Nepetas.

C.AT.ARIA. L.

Cat-mint.

Walls, yards, waste places.

Common. July - Sepitember.

GLECHOMA, Beuth.

From the ancient Glechon.

Dooryards. hedges, grass lands: sometimes in deep wood and and ravines.

Abundant. May-August.

DR ACOCEPHALUM, $L$.

Dragonhead.

PAR VIFLORU, Nutt.

Small-flowered Dracocephalum.

Barren fields and woods. Watertown, Jeffurson county. Gray in Rare plants of Northern N.Y. Brownville, Crawe in herb. Sartwell Ham. Coll. Rocky soil on the road between Watertown and Sackett's-larthor, Knistiern. Rocky banks of Black river, Vasey. Rocky bauks of small lakes and rivers, St. Lawrence county, Torrey Fl. N.Y.

Rare. May - August.

BRUNELLA, Tournefort.

VELGARIS, $L$.

Roadsides, meadows, deep woods.

Selfheal. Healall.

Common Brunella.

Common. June - Angust

SCUTELLARIA, $L$.

PARVula, Michx.

Shullcaps.

Dwarf Scutellaria.

Hillsides. St.Lawrence river; near Montreal, Macrae in herb. Sartwell Ham. Coll. Shore ol Lake Outario, Gray, Torrey Fl. N.Y. Rare. May, June.

GALERICULATA, L.

Swamps and flats of streams.

LATERIFL ORA, $L$.

River-banks and wet woods.

MARRUBIUM, $L$.

VULG.ARE. L.

Waysides, river-banks. Schenectady, Pearson. Penn-Yan, Sartwell in herb. Hain. Coll.

GALFOPSIS, $L$. TETRAHIT, L.

Damp waste places, river-banks.

STACHYS, $L$.

PALUSTRis, $L$.

Wet grass lands. var. AsperA, Gray.

Low grounds of streams. Infrequent. July, August.

Hooded Scutellaria. Abundant. August.

Side-flowering Scutellaria. Common. July, August.

Horehound.

Common Marrubium.

Hemp-nettle. Fourparted-flowered Galeopsis. Common. July - September.

Hedge-nettle. Marsh Stachys. Common. Rough Stachys. Frequent. July, August. 
IEONURUS, $L$.

$C . A R D I A C \cdot A, \mathrm{~L}$.

Motherwort.

Waysides, fences, waste places.

Cardiacal Leonurus.

Common. July - September.

LAMIUM, $L$ 。

Dead-nettle.

AMPLEXICAULE, L.

Clasping-leaved Lamium.

Roadsides. Schenectady near the Saratoga railroad, in wet woods, Pearson.

Fairfield, Hadley in herb. Near Bridgewater, Gray in cat.

Uncommon. May-November.

PHLOMIS, $L$.

TUBEROSA, L.

Jerusalem Sage.

Shore of Lake Ontario. Introduced and somewhat naturalized near Rochester, Chester Dewey in herb. Sartwell Ham. Coll.

June, July.

BORRAGINACE无.

Borages.

ECHIUM, Tournefort.

Blue-weed.

VULGARE, L.

Common Echium.

Roadsides and fields. Nyack, Rockland county, I. H. Hall. Schenectady, Pearson. Scarce. June, July.

LYCOPSIS, $L$.

ARVENSIS, $\mathrm{L}$.

Shores and waste grounds at Oswego.

Bugloss.

Cultivated-field Lycopsis. Rare. June - Angust.

SYMPHYTUM, Tournefort.

OFFICIN.ALE, L.

Waysides, flats of streams.

Comfrey.

Officinal Symphytum.

ONOSMODIUM, Michaux.

VIRGINIANUM, $D C$.

False Gromwell.

Dry hillse Saratoga county,

kern. Seneca lake, Sartwell.

CarolinianUM, $D C$.

Common. June - October.

Sandy grounds near Albany, G. W. Clinton, Beck bot. Stone creek, Gray. Rare. June - August.

LITHOSPERMUM, Tournefort.

ARVENSE, L.

Gromwell. Puccoon.

Hillsides, barren grounds. Along the Central railroad at Fort-Plain. Rocky banks of Black river.

Frequent. May, Junə.

OFFICINALE, L.

Roadsides, pastures.

LATIFOLIUM, Mich $x$.

Copses. Yates county, Sartwell in herb. Ham. Coll. Scottsville, Monroe county, L. Holzer.

HIRTum, Lehmann.

Hairy Puccoon. Rough Lithospermum.

Sandy sidehills near Irondequoit bay, Penfield, Monroe county, L. Holzer : C. M. Booth.

Rare. May, June. 
CANESCENS, Lehm.

Hoary Puccoon. Soft Lithospermum.

Dry fields. Jonesville, Saratoga county, L. Collins. Auburn, Caynga county, I. H. Hall Rare. May, June.

MERTENSIA, Roth.

Lungwort. VIRGINICA, $D C$.

Virginian Mertensia.

Rich grouuls along streams. Otsego county, H. Lathrop. Along Wood creek, near New-London, Gray. Banks of Oneida and Fish creeks, Knieskern. Steuben county, Sartwell in herb. Ham. Coll.

Rare. May.

\section{MYOSOTIS, $L$.}

PALUSTRIS, Withering. var. LAXA, Gray.

Forget-me-not. Marsh Myosotis. Spreading Myosotis.

Brook-sides. Abundant from Wood creek westward. May-September.

VERNA, Nutt.

Early Myosotis.

Stony fields, rocky banks. About Utica. Abundant on the barren sides of Black river below Watertown.

Frequent. May - July.

ECHINOSPERMUM, Swartz.

L.APPULA, Lehmann.

Stickseed.

Waste-crounds Common along the canal, from Utica southward. Dry gravelly banks, Oneidit-castle, Kniesliern. Chittenango falls.

Frequent. July - October.

CYNOGLOSSUM, Tournefort.

OF FICINALE, L.

Roadsides, ravines.

Hound's-tongue. Officinal Cynoglossum.

var. ALBUM.

Penn-Yan, Sartwell in herb. Ham. Coll.

VIRGINICUM, $L$. Common.

White-flowered Cynoglossum. June - September.

Virginian Cynoglossum.

Open woods. Near Vernon, J. S. Douglass, Knieskern. Yates county, Sartwell. Greece, Monroe county, Bradley.

Scarce. June - August.

Morisoni, $\boldsymbol{D C}$.

Wet thickets and wood borders.

HYDROPHYLLACE A.

\section{HYDROPHYLLUM, $L$.}

VIRGINICUM, $L$.

Woods and meadows.

CANADENSE, $L$.

Deep woods and ravines.

APPENDICULATUM, $M i c h x$.
Morison's Cynoglossum. Common. July - September.

Waterleafs.

Waterleafs. Hydrophylla.

Virginian Hydrophyllum. Common. June.

Canadian Hydrophyllum.

Abundant. July.

Appendaged-calyxed Hydrophyllum.

Damp rich woods. Flats of the Mohawk near Utica, Miss J. E. Johnson in herb. Parma, Monroe county, Bradley.
Rare. June. 
POLEMONIACE E.

Polemonia.

POLEMONIUM, Tournefort.

CARULEUM, $L$.

Greek Valerian.

Blue-flowered Polemonium.

Borders of a marsh three miles east of Charlottesville, Schoharie county,

New-York, E. C. Howe, Gray addend. bot. Delaware county, on the hills of Delhi, half a mile above the Salt-works; growing in great clusters along the marshy borders of a rivulet emptying into Elk creek, discovered by B. D. Gilbert.

Rare. June, July.

PHLOX, $L$.

Phloxes.

PANICULATA, $L$.

Panicled Phlox.

Cleared woodlands. Richfield, Otsego county, G.W. Clinton. Rare. July.

MACULATA, $L$.

Spotted-stemmed Phlox.

Escapes from cultivation. Roadsides in South-Trenton.

June.

DIVARICATA, $L$.

Divaricate-flowering Phlox.

Ravines and shady banks; often covering the ground in groves. Common throughout the Mohawk valley, and for greater or less distances up its creeks and tributaries; far up the Starch-factory creek; Deerfield creek; Sauquoit creek, above New-Hartford; Oriskany valley to Clinton : thus appearing as if brought from the West somehow. long ago.

The flowers present all colors from white through many shades of pink and lilac, to deep b!ue. Petals entire frequently. The leaves also vary from long ovate to narrow lanceolate.

May, June.

SUBULATA, $L$.

Moss-pink. Awl-like-leaved Phlox.

Rocky banks. Along the Genesee river below Rochester, east siide, $C$. $M$.

Booth; west side, G.T. Fish.

Rare. May.

CONVOLVULACE丑.

Bindweeds.

CALYSTEGIA, R. Brown.

SEPIUM, $R$. Br.

Banks of the Mohawk.

var. Repens, Gray.

Bräted Bindweeds.
Hedge Calystegia.

Common. July, August.

Creeping Calystegia.

Dry hillsides. Embankments of the Central railroad. Slaton's bush, toward Graefenberg hill.

Frequent. June, July.

SPITHAM瓜A, Pursh.

Span Calystegia.

Sandy copses. Schenectady, Pearson. Pine plains of Rome, Knieskern. Banks of Genesee river, L. Holzer

Rare. June.

CUSCUTA, Tournefort.

Dodders.

EPILINUM, Weihe.

Parasitic chiefly on flax. Schenectady, Beck bot.

Flax Cuscuta.

June, July.

GRONOVII, Willd.

Thickets, swampy woods.

SOLANACEA.

Dedicated to Gronovius.

Common. July - October.

Along streams; uncultivated cleared lands; under stone walls.

Common. June - August. 
NIGRUM, L.

Waste places and woods.

LYCOPERSICUM, Toumefort.

ESCULENTUM, Miller.
Black-fruited Solanum. Frequent. July - September.

Love-apple. Tomato.

Esculent Lycopersicum.

Eseapes from cultivation into waste places. Marshes of Salina, at the head of the lake.

July - September.

PHYSALIS, $L$.

Ground-cherry.

VISCOSA, $L$.

Clammy Physalis.

Roadsides, fences, old fields. Schenectady, Pearson. Otsego county, H.

Lathrop. Near Oneida lake, Gray. Penz-Yan, Yates county, Sartwell.

Infrequent. July, August.

ATROPA, $L$.

$B E L L A D O N N A, \mathrm{~L}$.

Naturalized in Parma, Monroe county, Bradley.

NICANDRA, Adanson.

PHYSALOIDES, Gærtner.

Neglected gardens and fields. Naturalized in Greece, Bradley.

Infrequent. July - September.

HYOSCYAMUS, Tournefort.

NIGER, L

Deadly Nightshade. Fair-lady's Atropa. Rare. June, July,

Apple of Peru. Physalis-like Nicandra.

Henbane.

Black Hyoscyamus.

Waste lots in cities. Abundant on waste banks and bottoms of Otsquago creek at Fort-Plain, Montgomery county. Otsego county, H. Lathrop. Oswego, about excavations.

DATURA, $L$.

STRAMONIUM, L. Officinal Stramonium. White-fluwered Datura. Streets of Albany and Utica.

var. TATULA, Torrey. Thorn-apple. Purple-flowered Datura. Waste-places about Schenectady. Roadsides a mile or two below Utica. About Bridgewater, Gray. Scarce. July - September.

GENTIANACE IE。

Gentians.

ERYTHRAA, Persoon.

Centaury.

CENTAURIUM, Pers.

The Ancient Centaurion.

Meadows and pastures. Oswegn, two miles northward near the Lake shore; two or three miles south of the city and east of the river, borders of woods.

Local. July - September.

FRASERA, Walter.

American Columbo.

CAROLINENSIS, Walt.

Carolinian Frasera.

Open dry wonds. Banks of the Genesee river, Hadley, which should be the reference in Torrey $\mathbf{F l} . \mathbf{N} . \boldsymbol{Y}$., instead of West-Canada creek, Gray. EastBloomfield, Ontario county, Sartwell. Penfield, Monioe county, L. Holzer: C. M. Booth. South of Muscow, Livingston county, Bradley. Rare. July.

GENTIANA, $L$.

Gentians.

QUINQEEFLORA, Lamarck.

Five-flowered Gentian.

Hillsides. Lake George and Fairfield, Hadley in herb. Factory glen; Rotterdam springs, Pearson. Bridgewater, Gray in cat. Borders of a beaver 
meadow, Vernon, J.S.Douglass, Knieskern. Rise of ground south of Leland's pond, and east of the road from Bouckville to Eaton. Madjson county; Greece, Monroe county, Bradley. Gorham, Sartwell in herb. Ham. Coll. Near Rochester, C.M.Booth : G.T.Fish. Rare. August - October.

CRINITA, Frölich.

Fringed-flowered Gentian.

Meadows, banks, borders of woods. Pine plains of Schenectady, Pearson. Borders of beaver meadows, Vernon, Douglass, Knieskern. Eaton, Madison county, and Greece, Bradley. Penn-Yan, Sartwell in herb. Ham. Coll.

Scarce. September, October.

ALBA, Muhl.

White-flowered Gentian.

Borders of streams. Abundant along the outlet of Owasen lake, I. H. Hall. Rare. August, September.

ANDREWSII, Grisebach.

Closed-flowered Gentian.

Wet banks, borders of swamps. Schenectady, Pearson. Wood and Fish creeks, Knieskern. Owasco lake, I. H. Hall. Frequent. August-October.

SAPONARIA, $L$.

var. LINEARIS, Gray.
Soapwort-leaved Gentian.

Linear-leaved Gentian.

Abundant along the streams and lake shores in the north woods. August.

BARTONIA, Muhlenberg.

TENELLA, Muhl.

Slender Bartonia.

Sandy woods and swamps. Pine plains of Rome, Knieskern. Deep swamps west of New.London.

Infrequent. August, September.

MENYANTHES, Tournefort.

TRIFOLIATA, $L$.

Buckbean.

Trifoliate Menyanthes.

Cold swamps. Littlefalls. Mud lake. Hidden lake. Frankfort hill. Rome. Point of Rock lake. Abundant in the northern part of the county and the north woods.

Frequent. May.

LIMNANTHEMUM, Gmelin.

LACunosum, Griseb.

Ponds, lakes. Oneida lake, Knieskern.

Floating-heart. Pitted-leaved Limnanthemum. Rare. June, July.

APOCYNACEA.

Dogbanes.

APOCYNUM, Tournefort.

ANDROS AMIFOLIUM, $L$.

Apocyna.

Hillsides, copses. Littlefalls. Open plains of Rome. Common. June, July.

CANNABINUM, $L$.

Hemp Apocynum.

Banks of streams. Abundant along the low banks of the Mohawk river. Fish creek.j

var. PUBESCENS, $D C$.

Pubescent-leaved Apocynum.

Northern part of the State, Gray. Troy, Aiken in herb. Sartwell Ham. Coll.

var. HyPericifolidm, Gray. Hypericum-leaved Apocynum.

East- and West-Canada creeks, Gray. Penn-Yan, Sartwell in herb. Ham. Coll. Frequent. June - August. 
ASCLEPIADACER.

Millkweeds.

ASCLEPIAS, $L$.

CORnut, Decaisne.

Roadsides, fences, ravines.

PHytolaccoides, Pursh.
Dedicated to CoRneTI. Common. June - August.

Pokeweed-like Asclepias.

Open woods, shores. Ballston lake, Pearson. Otsego county, H. Lathrop. Pine plains of Rome, and near Oneida lake, Knieskern. Greece, Monroe county, Bradley.

Frequent. June, July.

PURPURASCENS, $L$.

Deep-purple-flowered Asclepias.

Moist woods, along rivulets, water-sides. Banks of Sauder's lake, Schenectady county, Pearson. About Oneida lake, doubtless. Rare. July.

QUADRTFOLIA, Jacquin.

Four-leaved Asclepias.

Dry shady ground. In all pine woods of Schenectady county. Otsego county, H. Lathrop. Penn-Yan, Sartwell in herb. Ham. Coil. Uncommon. June.

obtusifolia, Michx.

Obtuse-leaved Asclepias.

Sandy plains. Between Albany and Schenectady, near Centre station. Schenectady, Pearson.

INCARNATA, $L$.

Along streams and shores.

Flesh-colored-flowered Asclepias.

Common. July.

TUBEROSA, $L$.

Tuberous Asclepias.

Hillsides and sandy plains. Abundant between Albany and Schenectady, and west to Amsterdam. Otsego county, H. Lathrop. Pine plains and borders of Oneida lake, Knieskern. Seneca county, Sartwell. Oak openings Greece, Bradley. Uncommon. July, August.

VERTICILLATA, $L$.

Whorled-leaved Asclepias.

Dry banks. Schenectady county, Pearson: Paige. Penfield, Monroe county, L. Holzer.

Scarce. July - September.

PERIPLOCA, $L$.

GREECA, L.

Periploca.

Grecian Periploca.

Naturalized. Near Rochester, Sartwell in herb. Ham. Coll.

Rare. July, August.

OLEACEA.

Olives.

LIGUSTRUM, Tournefort.

VULGARE, L.

Privet.

Naturalized from herdes. College grounds, Schenectady, Peuron. Benton,

Yates county, Sartwell in herb. Ham. Coll. Occasional. June.

FRAXINUS, Tournefort.

AMERICANA, $L$ 。

Forests.

PUBESCENS, Lamarck.

Woods. Schenectady, Pearson. Yates county, Sartwell in herb. Hum.Coll.

SAMBUCIFOLIA, Lamarck.

Swamps. Infrequent. May.

White, American Ash. Common. April, May.

Red, Pubescent Ash.

Black, Elder-leaved Ash. Common. April. 


\section{APETALOUS EXOGENS.}

ARISTOLOCHLACEA.

ASARUM, Tournefort. CANADENSE, $L$.

Ravine-sides.

\section{PHYTOLACCACE 2 .}

PHYTOLACCA, Tournefort. DECANDRA, $L$.

Borders of woods, cleared lands.

CHENOPODIACE F.

\section{CHENOPODIUM, $L$.}

$H Y B R I D U M, \mathrm{~L}$.

Waste grounds.

URBICUM, L.

var. Rномвіfolidm, Moquin. Wedge-leaved Chenopodium.

Streets, banks. Penn-Yan, Sartwell fide Carey in herb. Ham. Coll.

Rare. June, July.

$A L B U M, \mathrm{~L}$.

Roadsides, gardens.

White Chenopodium.

GLAUCUM, $L$.

Oak, Glaucous-leaved Chenopodium.

Abundant at Salina, and along the shores of Onondaga lake, where it is native, doubtless.

Rare. July - November.

BOTRYS, L.

Jerusalem-oak. Clustered-fruited Chenopodium.

Waysides, sandy wastes. Schenectady, Pearson. Banks of Fish creek, Vienna, Knieskern. Seneca lake, Gray. Penn-Yan, Sartwell in herb. Ham.

Coll. Rochester, C.M. Booth.

AMBROSIOIDES, L.

Roadsides. Salina. Penn-Yan, Sartwell in herb. Ham. Coll. Uncommon. August, September.

BLITUM, Tournefort.

MARITIMUM, Nutt. Infrequent. July - September.

Ambrosia-like Chenopodium.

Marshes at Salina, southwest shore of the lake, G.W. Clinton.

Rare. August, September.

CAPITATUM, $L$.

Strawberry, Capitate-fruiting Blite.

Roadsides, cleared lands. Schenectady, Pearson. Otsego county, Miss S. Cooper: H. Lathrop. Oriskany, Knieskern. Rome, Beck bot. Bridgewater, Gray in cat. Penn-Yan, Sartwell in herb. Ham. Coll. Greece, Monrve county, Bradley. Rare. June, July.

BONUS-HENRICUS, Reichenbach.

Good-King-Henry Blite.

Waysides, dooryards, gardens. Common in Clinton and the Oriskany valley Oriskany, Knieskern, Torrey Fl. N.Y. : in herb. Ham. Coll.

Rare. June - September. 
ATRIPLEX, Tournefort.

Orache.

IASTATA, $L$.

Hastate-leaved Atriplex.

Common at Salina, roadsides, marshes, shores of the lake; with all manner of variations, from small erect simple plants, having rongh brown seeds a line in diameter, through branching specimens with shining black seeds half a line in diameter, both light-green and covered with mealy scales; and a very large form with deep-green smooth leaves, seeds two lines in diameter, to

\section{var. OBLONGIFOLIA.}

Leaves entire, broadest at the end.
Oblong-leaved Atriplex. August - November.

SALICORNIA, Tournefort.

Samphire.

HERBACEA, $L$.

Herbaceous Salicomia.

Salt-marshes of Onondaga lake : common at Salina, and abundant on the west side of the lake opposite Liverpool.

Many of the low grounds are covered with this plant; and in autumn they are very beautiful, after a few frosts have turned them into fields of crimson. August, September.

\section{AMARANTACE正。}

Amaranths.

AMARANTUS, Tournefort.

HYBRIDUS, L.

Waste grounds.

RETROFLEXUS, L.

Gardens and fields.

ALBUS, L.

Roadsides, yards.

Hybrid Amarantus.

August - October.

Reflexed-haired Amarantus. Common. July - September.

White Amarantus.

August - October.

POLYGONACE E.

Buckwheats.

\section{POLYGONUM, $L$.}

GRIE NT ALE, L.

About gardens, rubbish.

Oriental Polygonum. July - September.

AMPHIBIUM, $L$.

Amphibious Polygonum.

In the lakes of the North woods a form abounds, much larger than the next and apparently quite different, growing with it.

var. AQUATICUM, $L$.

Water Polygonum.

Sander's lake, Pearson. Oneida lake, Knieskern. East Dry-lot pond, south Herkimer county. In all the lakes and ponds from Otsego to Madison counties, Gray. Leland's pond, Eaton, Madison county, Bradley. Common in the lakes of the north woods.

var. TERRESTRE, Torrey.

Shore Polygonum.

Coon Chisholm's. Schenectady, Pearson. Borders of a millpond near Winfield. Along the outlet of Owasco lake, I. H. Hall. Cayuga lake, Gray.

Frequent. July - September.

Noposum, Persoon.

var. INCARNATUM, Gray.

Low banks of the Mohawk.

PENNSYLVANICUM, $L$.

Brooksides, marshes.
Nodding Polygonum. Flesh-colored Polygonum. Infrequent. August - October.

Pennsylvanian Polygonum. Abuudant. July - October. 
CAREYT, Olney.

Liscovered by J. CAREY.

Upland swamps. Abundant in the half-open mossy bogs north of Summit lake, Otsego county. Marshy borders of Mud lake, south Herkimer county. Rare. September, October.

PERSICARIA, L.

Waste grounds, rear dwellings.

HYDROPIPER, L.

Ditches, marshy places.

ACRE, H. B. K.
Peachileaved Polyoonum.

Common. July, August.

Waler-pepper Polygonum. Common. Augist - October.

Pungent Polygonum.

Water-sides. Abundant in the marshes along the outlet of Cayuga lake. Sivamp near Owasco lake, I. H. Hall.

Infrequent. July, August.

HXDROPIPEROIDES, Michx.

Water-pepper-like Polygonum.

Wet bauks. Shores of Orondaga lake. Uncommon. August - November.

AVICULARE, $L$.

Paths, yards.

Var. ERECTUM, Roth.

Damp wastés.

ARTICULATUM, $L$.

Sandy plains. West of Albany, Eaton, Beck, Torrey. Schenectady, Pearson. Shore of Oneida lake, Gray, Torrey Fl. N.Y. Sandy borders of Oneida lake, Knieskern.

VIRGINIANUM, $L$.

Rich woods, flats of streams.

ARIFOLIUN, $L$.

Wet thickets.

SAGITTATUM, $L$.

Swamps.

CONVOLVULUS, L.

Barren and cultiva:ed grounds.

Cilinode, Mich $x$.

Damp thickets, on the Deerfield hills.

DUMETORUM, $L$.

Banks of streams, bushes.

FAGOPYRUM, Tournefort.

ESCULENTUM, Mœnch.

Field-borders, woods, and often in deep swamps. Frequent. June-August.

\section{RUMEX, $L$.}

VERTICILLATUS, $L$.

Docks.

Bogs on the flats of the Mohawk. Throughout the upland swamps sonth of the Mohawk valley, Gray.

HYDROLAPATHUM, Hudson.

Frequent. June, July.

Water-dock Rumex.

var. Americandu, Gray. American'Water-dock Rumex. Marshes, both on the hills, and in lowlands of rivers and lakes.

Frequent. July. 
OBTUSIFOLIUS, L.

Farmyards, fences, borders of woods.

Obluse-leaved Rumex.

CRISPUS, L.

Common. Junc, July.

Ditches, fields.

Curled-leaved Rumex.

Common. May - July.

S.ANGUINEUS, L.

Barnyards, pastures.

Blnody-veined Rumex.

Scarce. June, July.

ACETOSA, L.

Garden-sorrel Rumex.

Cultivated grounds. About gardens on Paris hill. Peun-Tan, introrluced,

Surtwell in herb. Ham. Coll.

Infrequent. June, July.

ACETOSELLA. L.

Sheep-sorrel Rumex.

Barren meadows, pastures.

Common. May - July.

LAURACEA.

Laurels.

SASSAFRAS, Nees von Esenbeck.

Sassafras.

officinale, Nees.

Officinal Sassafras.

Sandy open woods. Abundant in the woods and copses of Schencetady county. Pine plains of Rome, at the head of Oneida lake. Penn-Yan, Sartwell in herb. Hain. Coll.

Frequent. April, May.

BENZOIN, Nees von Esenbeck.

oDORIFERUM, Nees.

Damp copses, swamps.

Spicebush. Feverbush. Fragrant Benzoin. Common. April.

THYMELEACE正.

Daphnads.

DIRCA, $L$.

PALUSTRIS, $L$.

Flats of streams, deep woods.

Leatherwood. Marsh Dirca. Abundant. April.

ELAAGNACEA.

Oleasters.

SHEPHERDIA, Nuttall.

Shepherdia.

Canadensis, Nult.

Canadican Shepherdia.

Ravine-sides, rocky banks of streams. Fairfield. Herkimer connty, Gray. Trenton falls, West-Canada creck, Knieskern. Deerfield creck opposite Utica, high on the slaty sides of the gulf, from its entrance far up the headwaters of the stream. East banks of Onondaga lake. Rocky sides of Black river.

Erequent. May.

SANTALACEA.

Sandalwoods.

COMANDRA, Nultall.

UMBellata, Nutt.

Umbellate Comandra.

Dry rocky banks; open sandy woods and their borders. Throughout the valley of the Mohawk, from Schenectady to Oneida lake. Frequent.

A form occurs in the swamp of West-Bergen, Genesee county, in open places of damp moss or wet marl, in company with Solidago ohivensis, S. houghtonii, and among the running stems of Juniperus sabina, having large orate obtuse glaucous leares, often nearly iwo inches long by over half an inch wide; bearing fluwers and fruit on short perlicels, in a leafy terminal simple raceme; berries large, fleshy, yellow or red, instead of the dry hard black nutlets of the common plant.

It was first thought to be C. livida, but is still undetermired. June. 
SAURURACE 2 .

SAURURUS, $L$.

Cernưs, $L$.
Saururads.

Lizard's-tail.

Nodding Saururus.

Swamps and water-sides. Borders of Oneida lake, Kninsiern, Gray. Low woods east of Onondaga lake. Swamps southeast of Oswego. Banks of streams between Srracuse and Savannah, Cayuga river marshes. Owasco lake outlet, I. H. Hall. Common along Clyde river. Frequent. July, August.

\section{CERATOPHYLLACEA.}

CERATOPHYLLUM, $L$.

DEMERSUM, $L$.

var. echinatum, Gray.

Hornworts.

Hornwort.

Submerged Ceratophyllum.

Rough Ceratophyllum.

Slow-flowing or still water. Outlet of Canaderaga lake, where it flowers and fruits readily. Penn-Yan, Sarlwell in herb. Hain. Coll.

Infrequent. June, July.

CALLITRICHACEAE.

CALLITRICHE, $L$.

VERNA, $L$.

Still water beside streams, ponds.

forma TERRESTRIs, Engelmann.

Muddy banks. Milipond at Cedarville.

AUTUMNALIS, $L$.

River borders. Borders of Canaderaga lake outlet. Alesandria bas, G. W.
Water-starworts.

Water-starwort. Vernal Callitriche.

Frequent.

Moss Callitriche. Uncommon, June - August.

Autumnal Callitriche.
Clinton.

\section{PODOSTEMACE $\mathbb{E}$.}

PODOSTEMON, Michaux.

CERATOPHYLLUM, Mich $x$.
Rare. August.

River-weeds.

River-weed.

Horn-leaved Podostemon.

Stony bottoms of streams. In flowing water, Watertown, Jefferson county, Crawe: Gray in Rare plants of Northern N.Y. Watertown. Crawe in herb. Sartwell Hum. Coll. Rare. July, August.

\section{EUPHORBLACE E.}

Spurges.

\section{EUPHORBIA, $L$.}

POLYGONIFOLIA, $L$.

Spurges. Euphorbia.

Shores Nouth of Genesee river, Sartu at Charlotte, C.M. Booth.

MACULATA, $L$.

Roadsides, banks of streams.

HYPERICIFOLIA, $L$.

Damp gravelly places, hillsides.

HELIOSCOPIA, L.

Shores of Onondaga lake; most abundant at its head, Salina.

Rare. July - October.

PLATYPHYLLA, $L$.

Broad-leaved Euphorbia.

Pastures, roadsides. Winfield, south Herkimer county. Paris hill. Clark's mills, towards Pratt's settlement. 
ACALYPIIA, $I_{\text {。 }}$

VIRGINICA, $L$.

Roadsides, moist grounds.

URTICACEA.
Three-seeded Mercury.

Virginian Acalypha.

Common. August - October.

ULMUS, $L$.

Fulva, Michx. Nettles. Elms.

(O) , il hilly woods along rivulets, and banks of strcams. Common along the Mohawk.

Frequent. April.

AMERICANA, $L$.

Woods, hills and dales.

RACEMOSA, Thomas.

White, American Elm.

Common. April.

Corky, Racemed Elm.

Brows of ravines, river-banks. Abundant along the Mohawk and its tributaries.

April.

CELTIS, Tournefort.

occidentalis, $L$.
Netlletree. Sugarberry.

Western Celtis.

Rocky woods and baniss. Near Oneida lake, Knieskern. Gorham, Ontario county, Sartwell.

Rare. April, May.

MORUS, Tournefort.

Mulberries.

RUBRA, $L$.

Red Mulberry.

Open woods. Near the Aqueduct, Schenectady, Pearson. Penn-Yan, Yates county, Sartwell in herb. Ham. Coll.

Scarce. May.

\section{$A L B A, \mathrm{~L}$.}

White Mulberry.

Woods, and about houses, Knieskern. Frequent in Schenectady county, in thickets along road-fences, and often a tree. Penn-Yan, introduced, Sartwell in herb. Hurn. Coll.

Occasional. May.

URTICA, Tournefort.

GRACILIS, Aiton.

Fences, river-banks.

DIOIC.A, L.

Nellles.

Tall, Slender Nettle. Common. July, August.

Direcious Nettle.

Waste places. Schenectady, Pearson. Oneida county, Knieskern. Gorham, Ontario county, sartwell.

Uncommon. June - August.

LAPORTEA, Gaudich.

CANADENSIS, Gaud.

Ravines and damp woods.

Wood Neltle. Canadian Laportea. Common. July.

PILEA, Lindley. Clearweed. PUMILA, Gray. Low Pilea.

Shaded springy banks; borders of streams in wooded ravines.

Common. July, August.

BEHMERIA, Jacquin.

False Nettle.

CYLINDRICA, Willd.

Swamps and wet open woods.

Cylindric-fruited Boehmeria.

Frequent. July, August.

PARIETARIA, Tournefort.

PENNSYLVANICA, Muhl.

Pellitory.

Pennsylvanian Parietaria.

Shady hillsides; rocky sides of streams. Ithaca, Tompkins county, Sartwell in herb. Ham. Coll.

Rare. May - July. 
CANNABIS, Tournefort.

S.ATIV $A, \mathrm{~L}$.

Waste lots in cities, towns.

Hemp.

Cultivated Cannabis.

Frequent. June - August.

\section{HUMULUS, $L$.}

LUPULES, $I_{\text {. }}$.

Hop-vine.

Shaded banks of the Mohawk and Unadilla rivers.

Frequent. July.

PLATANACE无.

Sycamores.

PLATANUS, $L$. occidentalis, $L$.

Banks of creeks and rivers.

Plane-tree. Bulton-ball-tree. Buttonwood. Western-vorld Platanus. Common. May.

JUGLANDACE E.

Walnuts.

JUGLANS, $L$.

CINEREA, $L$.

Hilly woods; flats of streams.

NIGRA, $L$.
Butternut. Gray Walnut. Abundant. May.

Black Walnut.

Fertile woodlands. Common around Seneca lake, Sartwell. Scarce, May.

CARYA, Nuttall.

Hickories.
ALBA, Nutt.
Shag-bark, White Hickory.

Fertile woodlands and vallies. Abundant in the valley of the Hudson about Albany. Around Otsego lake, Miss S. Cooper. Borders of Canaderaga lake. Valley of the Mohawk throughout, from the Hudson to Oneida lake.

Frequent, May.

TOMENTOSA, Nutt.

Mocker-nut. Downy Hickory.

Rich woods. Schenectady county, Pearson. Oneida county, Knieskern.

Infrequent. May.

GLABra, Torrey.

Smooth Hickory.

Chiefly in meadows, pastures.

Abundant. May.

AMARA, Nutt.

Low woods, ravine-sides, streams.

Swamp, Bitter Hickory.

Common. May.

\section{CUPULIFER $\mathrm{E}$.}

Oaks.

\section{QUERCUS, $L$.}

macrocarpa, Michx.

Over-cup, Large-fruited Oak.

Groves, water-sides. Abundant along the borders of Onondaga lake, west side.

Scarce. Fl. May : Fr. September.

var. OLIV AForMis, Gray. Mossy-cup, Olive-formed Oale. River-banks; of the Hudson above Albany, and in the western part of the State, Michaux. Glenville near Schenectady, Pearson. Dexter, Jefferson county, Vusey.

Rare.

obTUsiloba, Michx.

Post, Round-lobed Oalc.

Sandy woods. Schenectady, along the College brook; woods beyond the junction of the Central and Saratoga railroads, Pearson.

Rare.

ALBA, $L$.

White Oak.

Hilly woods.

Frequent. 
PRINUS, $L$.

var. DISCOLOR, Mich $x$.

Turo-colored-leaved Oak.

Low woods. Flats of the Mohawk. West side of Onondaga lake. Abundant. CASTANEA, Willd.

Chestrut-leaved Oalc.

Elevated woodlands. Chemung county, Knieskern, Torrey Fl. N.Y. Rare. var. MontiCola, Michx.

Mountain-duelling Oak.

Rocky hillsides and banks. Schenectady county, Pearsor. Ilighlands of the Mohairk, E.W.Paige. Penn-Yan, surtwell in herb. Ham.Coll. Infrequent.

PRTNOIDES, Willd.

Pine plains of Schenectads, Pearson.

ILICIFOLIA, Wangenheim.

Pine plains of Rome.

Tinctoria, Bartram.
Chinquapin. Prinus-like Oak.

Scarce.

Scrub, Ilex-leaved Oak. Abundant.

Quercitron. Dyeing Oak.

Fertile woods. Schenectady, Pearson. Otsego connty, Miss S. Cooper: H. Lathrop. Yates county, Sartwell in herb. Ham. Coll. Uncommon.

COCCINEA, Wang.

Scarlet Oak.

Hillsides. Schenectady, Pearson. Around Otsego lake, Miss S.Cooper. Pean-Yan, Sartwell in herb. Ham. Coll.

Frequent.

RUBRA, $L$.

Woods.

Red Oak.

Common.

PALUSTRis, Du Roi.

Swamp Oak.

Borders of swamps, flats of streams. Schenectady, Pearson. Occasional.

CASTANEA, Tournefort.

Chestnut.

VESCA, $L$.

Hillsides.

FAGUS, Tournefort.

FERRUGINEA, Aiton.

Woods.

CORYLUS, Tournefort.

AMERICANA, Waller.
Edible-fruited Chestnut.

Frequent. July.

Beech.

Rusty-leaved Fagus.

Common. May.

Filberts. Hazelnuts.

American Corylus.

Low woods, river-banks. Common in the valley of the Mohawk. April.

rostrata, Aiton.

Beaked Corylus.

Thickets along streams. Schenectady, Montgomery and Otsego counties. Rocky banks of Seneca lake, Vasey. Banks of Owasco lake outlet, I.H.Hall. Tates county, Sariwell in herb. Ham. Coll.

Infrequent. April.

CARPINUS, $L$.

AMERICANA, Michx.

Ravine-sides.

Water Beech. American Carpinus.

Common. April.

OSTRYA, Micheli. VIRGINICA, Willd.

Moist open woods.
Hop-hornbeam. Lever-uood. Iron-wood.

Virginian Ostrya.

Common. May. 
MYRICA, $L$.

Siceet-gale.

GALE, $L$. Helmeted-fruited Myrica.

Cold marshes, near Summit la'ke, Springfield. Otsego county, where it abounds. Mnd lake, south Herkimer cuunty. Conmon on the margius of streams and lakes in the nortin woods.

April.

CERIFERA, $L$.

Bayberry. Wax-bearing-fruited Myrica.

Sandy shores. Junius, Sartwell in herb. Ham. Coll. Rochester, C. Dewey. Parma, Monroe county, Bradley. Abundant in the swamps of West-Bergen, northeastern Genesee county.

Rare. May.

COMPTONIA, Solander.

asplenifolia, Aiton.

Siceet-fern.

Hillsides and sandy plains. Pine woods of Schenectady county, Pear Otsego county, Miss S. Cooper. Plains of Rome and Oneida lake.

Frequent. April, May.

\section{BETULACE 伥.}

Birches.

BETULA, Tournefort.

alba, var. poptlifolia, Spach. White, Poplar-leaved Birch.

Barren or sandy soils. Plains and swamps between Albany and Schenectady. Otsego county, Miss S. Cooper. Abundant on the pine plains of Rome. Dry banks of the Black river.

Frequent. April.

PAPYRACEA, Aiton.

Paper Birch.

Banks of streams. Helderberg mountains, Pearson. Along the Black river below Dexter, Jefferson county, Vusey.

Rare.

NIGRA, $L$.

Black Birch.

Banks of streams. Deerfield creek. Fish creek.

Scarce.

EXCelsa, Aiton.

Damp woods.

Yellow, Lofty Birch. Common.

LENTA, $L$.

Cherry, Pliant Birch.

Ravines.

Frequent.

ALNUS, Tournefort.

Alders.

INCANA, Willd.

Hoary Alder.

Upland marshes on the hills south of the Mohawk valley. Summit lake, Springfield; where it is very low, only a foot or two high, on the open bog land. Borders of Canaderaga lake and its outlet, Exeter, Otsego county. From Mud lake, to the State marsh, south Herkiner county.

Infrequent. March, April.

Serrulata, Aiton.

Streams, swamps.

VIRIDIS, $D C$.

Northern watercourses. Among the headwaters and on the banks of Moose river, north Herkimer and Hamilton counties.
Serrulate Alder.

Common.

Green Alder. 


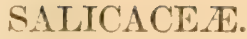

Willows.

SALIX, Tournefort.

Salices.

CANDIDA, Willd.

Hoary Willow.

Cold swamps. Summit lake borders. Otsego county. Mud lake, State marsh, Iidden lake, Litehficld, south Herkimer county. Junius, Seneca county, sartwell. West-Bergen, Genesec county.

Rare. May.

TRISTIS, Liton.

Dry open woods.

Mourning Willow.

CMILIs, Marshall.

Infrequent.

Borders of thickets and swamps. Pine plains of Rome. Frequent.

DISCOLOR, Muhl.

Glaucous, Two-colored Willow.

Banks of streams.

Common.

SERICEA, Marshall.

Silky-leaved Willow.

Low gronuds, water-sides. Borders of swamp-rirulets near Point of Rock pond, and in the northern part of the county. Yates county, Sartwell in herb. Ham. Coll.

Scarce.

PETIOLARIs, Smilh.

Petioled Willow.

River-banks. Occasional on the low alluvial banks of the Mohawk. PennTan, Sartwell in herb. Ham. Coll.

Üucommon.

CORdata, Muhl.

Heart-leaved Willow.

Low river-banks. Penn-Yan, Sartwell in herb. Ham. Coll. Frequent.

rostrata, Richardson.

Long-beaked Willow

Borders of swamps. Steep springy banks of the Oriskany creek. Rome, Knieskern, Torrey Fl. N.Y.

Infrequent.

$A L B \wedge, \mathrm{L}$.

Low grouuds, wet banks.

White Willow.

Common.

FRAGILIS, L.

Brittle Willow.

Water-sides. Starch-factory creek. Headwaters of the Deerfield creek. Banks of the Mohawk and its tributaries.

Uncommon.

NIGRA, Marshall.

Black Willow.

Banks of creeks, rivers. In force on the alluvial banks of the Mohawk.

Common.

LUCIDA, Muhl.

Shining Willow.

Low banks. Borders of Hidden lake, Litchfield, south Herkimer county; and all the cold marshes on the hills. Yates county, Sartwell in herb. Ham. Coll.

Infrequent.

$B A B Y L O N I C A$, Tourn.

Weeping Willow. Streets, lawns, graveyards.

Frequent.

LONGIFOLIA, Muhl.

Long-leaved Willow. Sandy banks. Albany, Beck in herb. Genesee falls, Aiken in herb. Sartwell Harm. Coll.

Scarce.

pevicellaris, Pursh.

Pedicel-fruited Willow.

Sphagnum swamps. In the cold open bogs north of Stunmit lake, Otsego cuunty. Abundant on the State marsh and around Hidden lake, Litchfield, south Herkimer county. Oriskany swamp formerly, Knieskern. Cold marshes in the northwestern part of the county, and throughout the north woods. Junius, Seneca county, Sartwcll in herb. Ham. Coll.

Rare. 
POPULUS, Tournefort.

TREMULOIDES, Michaux.

Sides of hills and ravines.

GRANDIDENTATA, Mich $x$.

Woods and river-banks. Most frequent on sandy soils.
Poplars. Aspen.

Tremula-like Populus.

Common. April.

Large-toothed-leaved Populus.

monilifera, Aiton. Cottonuood. Necklace-bearing Populus.

Water-sides. Western part of the State, particularly near Oneida lake and along the Genesee river, Torrey Fl. N.Y. Pillar point near Dexter, Jefferson county, Vasey. Near Rochester, C. M. Booth.

Rare,

BALSAMIFERA, $L$.

Balsam-bearing Populus.

Water-courses, swamps. Near Oriskany, Knieskern.

Scarce.

var. CANDICANs, Gray.

White-leaved Populus.

Streets and near dwellings; a common shade tree.

NIGRA, Michx.

Black Populus.

Banks. Oriskany ereek, and near Oneida lake, Knieskern. Rare.

DIL.AT.AT.A, Aiton.

Roadsides; near old farm-houses.

$A L B A, \mathrm{~L}$.

Lombardy Poplar. Dilated-leared Populus.

Occasional as a shade tree; extending by root, to fences and roadsides

Frequently.

2. GYMNOSPERMÆ.

Gymnosperms.

\section{CONTFER死.}

PINUS, Tournefort.

RESINOSA, Aiton.
Conifers.

Pines.

Red, Resinous Pine.

Hills. Helderberg monntains three miles south of Knowerville, Pearson.

Pine plains of Rome, Vasey. Yates county, Sartwell in herb. Ham. Coll.

May. Rare.

RIGIDA, Miller.

Sandy plains. Schenectady. Rome.

\section{Pitch, Rigid Pine.}

Common. May. STroBUs, $L$.

White Pine. From an ancient Fir.

Cold roods. Swamps on the flats of the Mohawk. Frequent in Schenectady. Montgomery and Otsego counties. Lingering still in marshes on the hills : formerly abounding throughout this region. Tot yet exhausted in the swamps of Rome and Oneida lake. Common in the forests of the north woods. May.

ABIES, Tournefort.

Balsamea, Marshall.

Spruces.

Balsam-yielding Fir.

Cold swamps. Occasional in upland marshes, south of the Mohamk ralley, from Summit lake and the outlet of Canaderaga lake, Otsego county, through the swamps near Jordanville, to the State marsh and Graefenberg swamp, south Herkimer county. Between Oriskany and Rome. Abundant in the northern part of the county; and common along streams and shores in the north woods, often nearly covered with long gray lichens.

June.

Canadensis, Michx.

Hemlock.

Dry woods.

Common. May.

[ON. PL.] 
Nigra, Poiret.

Black Spruce.

Deep wonds on the hills: on the level borders of sphagnum ponds. Frequent along Fish creek, above the eliffs. Common in the northern forests.

The low dwarf form, in bogs and holes, is ealled by lumbermen Bastard spruce. This and the Tamarack are the first trees that take root in shaking moss, either as it extends into the water of ponds, or after it has completed the covering. They are closely followed and displaced by Arbor vite; which at length develop the deep black soil-bottoms of cedar swamps.

Frequent. May.

ALBA, Michx.

Open upland woods. Frankfort hill. Northern wilderness.

White Spruce. May.

LARIX, Tournefort.

Larch. Tamarack. americana, Micikx.

American Larix.

Borders of swamps and marshes. Thronghont the valley of the Mohawk, but more abundant along the south range of hills, around the ponds and lakes, or occasionally alove covering tracts of low land. Also from the northern part of the county, northward.

Abundant. May.

THUJA, Tournefort.

OCCIDENTALIS, $L$.

Arbor-vita.

Cold swamps. From northern Otsego county, Summit lake; southern Herkimer county, Mud lake, Cedarville, Hidden lake, Cedar lake; Oneida county, throughout the valley of the Mohawk; Madison and Ouondaga counties; northward.

Common. April.

JUNIPERUS, $L$.

Junipers.

COMMUNIs, $L$.

Common Juniper.

Sandy woods, barren banks. North side of the Mohawk valley, from Schenectady to Littlefalls. Sides of the Black river below Watertown. Frequent in the north woods.

Scarce. May.

VIRGINIANA, $L$.

Red Cedar.

Rocky woods, dry sidehills. Alundant in the valley of the Mohawk, through Schenectady and Montgomery counties. Seneca lake, Gray. Greece, Monroe county, Bradley. Frequent, April.

SABINA, $L$.

European Savin.

var. PROSTRATA.

Low Savin. Prostrate Juniperus.

Swamps and shores. Borders of cold ponds in the north woods. Chemung county, Knieskern in herb. Sartwell Ham. Coll. Banks of the Genesee river, Greeoe, Bradley. Abundant in the Bergen swamp, Genesee county; often covering the ground, and running to great length.

Leavds four-ranked, oval, acute; at the end of the stem, opposite, cuspidate : sterile flowers in erect ovoid catkins, borne on the ends of little branches: fertile catkins of several scales becoming fleshy and uniting in a berry, glaucous at first, blue-black when ripe, two-to four-seeded, borne on slort recurved pedicels, which is the determining characteristic of the species.

In open places, stems run several feet, rooting as they go: branches curving upwards three to eight inches; but where the plants are crowded in patches, they rise twelve to eighteen inches.

Rare. May.

TAXUS, Tournefort.

Yew.

BACCATA, L., var. CANAdensis, Gray.

American Taxus.

Moist banks of woods and ravines, in deep evergreen shade. Common.

Sometimes erect, with a tree-like stem and spreading branches, five or six feet in height : borders of the Paris hill swamp.

April. 
ARACE E.

ARIS EMA, Martius.

TRIPHYLLUM, Torrey.

Ravine-sides, moist woods.

DRACONTIUM, Schott.

Damp thickets on the flats of the Mohawk.

PELTANDRA, Rafinesque.

VIRGINICA, $R$ af.

Swamps, sides of streams.

CALLA, $L$.

PALUSTRIS, $L$.

Bogs, streams ponds. Frequent. Common on Graefenberg hill.

Often with two, and sometimes three spathes surrounding one spadix. May - August.

SYMPLOCARPUS, Salisbury. FETIDUs, Salisb.

Low meadows, swamps.

ORONTIUM, $L$. AQUATICUM, $L$.

Skunk Cabbage.

Fetid Symplocarpus. Common. March, April.

Golden-club. Floating Orontium.

Borders of a pond in Gilbertsville, Otsego county, H. Lathrop in herb. The specimen of this plant is clear, and that it was gathered within the limits of a botanical walk from this place is certain. The station, however, is wonderfully inland for a plant usually found around ponds near the coast and in river-marshes of tide-water, being nearly four hundred miles up the Susquehanna valley.

ACORUS, $L$.

CALAMUS, $L$.

Rivulet-marshes.

TYPHACE E.

TYPHA, Tournefort.

LATIFOLIA, $L$.

Swamps.

ANGUSTIFOLIA, $L$.

Common around Onondaga lake and west of Syracuse.

SPARGANIUM, Tournefort. EURYCARPUM, Engelmann.

Bur-reeds. Spargania. Broad-fruited Sparganium.

Lake and river borders. Abundant along the outlet of Canaderaga lake, Exeter, Otsego county. Probably not uncommon on the flats of the Mohawk. Its habit alone would distinguish this species, the plant being as large again in all its parts as the following.

rAMOSUM, Hudson.

Marshes along streams.
August, September.

Branched-headed Sparganium. Common. July, August. 
SIMPLEX, Hudson

Margins of ponds, lakes.

NATANS, $L$.
Single-headed Sparganium

Frequent. July.

Floating Sparganium.

Slow-thwing brooks. On the Hats of the Mohawk, a mile or two helow Lica.

Rare. July.

ANGESTIFOLIUM, Michx.

Narrow-leaved Sparganium.

Margins of cold springs and high ponds in the northern part of Herkimer county.

Rare. July.

LENINACEA.

Duckmeats.

LEMNA, L.

TRISULCA, $L$ 。

Ivy-leaved, Three-parted Lemna.

Still water. Pond on the flats below Utica. Alexandria bay. Gates, Monroe county, found in flower by C.M. Booth.

MINOR, $L$.

Uncommon. June.

Stagnant water.

Little Lemna.

Common.

POLYRRHIZA, $L$.

Ponds.

Many-rooted Lemna.

Frequent.

GIBBA, $L$.

Convex-leaved Lemna.

Ditches and stagnant waters; observed in flower, near Liverpool in the western part of New-York State, Pursh. Onondaga lake.

Rare.

\section{NAJADACE无.}

Najads.

NAJAS, $L$.

MAJOR, Allioni.

Greater Najas.

Borders of Onondaga lake. Discovered hy G. W. Cunton, in October 1864, growing in a stream emptying into the lake near Liverpool.

It abounds, however, in the lake. in water ten to twenty-five feet deep; most luxuriantly along the erge of a sudden descent of the bottom, at a distance from shore. When the water is clear and still, the plants can be seen growing on the bottom, branching in all directions from the root. But the best specimens come from the deepest water, out of sight; some clusters of which are three feet in length. and these only fragments hroken off ly storms.

At least three forms occur. The common one is entirely unarmed, without spines either on stems or leaves; perhaps the var. angustifolia, BRAON, observed by Снамrsso at Oahu, Sandwich Islands.

Another corresponds with the normal form described by Prof. Alexander Br.trx : Stem sparingly beset with spines $(10-40$ in each internode); leaves broad-linear, each edge of the blade with $4-8$ teeth. which are patent and not quite so long as the leaf is broad, the leaf at the back furnished with $1-4$ spines; sheath of leaf with rounded lateral edges, and without teeth; fruit 5-8 millimetres long.-Florida, CABANIs.

A small form occasionally appears, about half the size of the first in all the parts and fruit.

The above habitats, with our own, are the only stations of this plant known on the American continents : it is widely distributed over the Old world.

Local. August - November.

\section{FLEXTLIS, Rostkov \&. Schmidt.}

Bending Najas.

Lakes. rivers. Outlet of Canaderaga lake, Otsego county. Lake Ontario. Cape Vincent, head of the St.Lawrence, Bradley. Abundant in the river south of Oswego. Crooked lake, Surtwell. Infrequent. July-September. 
Rivulets, marshy shores. Salina and Onondaga lake. Near Penn-Yan, Sartwell.

Rare. August - October.

\section{RUPPIA, $l$.}

Tassel Pondweed.

MARITIMA, $L$.

Seaside Ruppia.

Borders of Onondaga lake along the east side. It is fruitful in shallow water, two to five feet in depth.

In deep water, in company with Najas major, a very large form grows, many feet in length, bearing wide leaves, but flowerless and fruitless.

This plant and its companion are new to the interior, having been known hitherto as exclusively maritime. Their presence here is proof, first, that the sea originally came up to or covered the place; and second, that these plants were flourishing at that time. July - November.

POTAMOGETON, Tournefort. PECTINATUS, $L$.

Pondweeds.

Rivers and lakes. Albany, Beck. Schenectady Pearson. Near Watertown, Gray, Torrey Fl. N.Y. Pools along Oriskany creek. Abundant in Onondaga lake. Crooked lake, Sartwell. Rare.

RоввINSII, Oakes. Discovered by RoBBins. Ponds. At the hear of Onondaga lake, in the inlet of the creek. Rare. PUsillus, $L$.

Small Potamogeton.

Borders of lakes, standing waters. East Dry-lot pond, south Herkimer county. Crooked lake, Yates county, Sartwell. Rare.

PAdCiflorus, Pursh.

Few-flowered Potamogeton.

Standing water along streams; canals.

Common.

COMPRESSUS, $L$.

Flat-stemmed Potamogeton.

Slow waters. Outlet of Canaderaga lake, Otsego county, where it abonnds. Sander's lake and the Mohawk; Pearson. River St.Lawrence at Alexandria bay. Yates county, Sartwell in herb. Ham. Coll.

Uncommon.

\section{PERFoliatus, $L$.}

Canals, ponds.

PR AlLoNGUs, Wulfen.

Perfoliate Potamogeton.

Common.

Long-peduncled Potamogeton.

Still deep water. Alexandria bay, Jefferson county, at the mouth of the creek : peduncles eighteen inches in length.
LUCENS, $L$.

Bottoms of ponds in shallow water. var. FLUTTANs, Gray.

Ponds in deep water.

NATANS, $L$.

Lakes, rivers.

HETEROPHYLLUs, Schreb.
Scarce.

Shining-leaved Potamogeton. Frequent.

Floating Potamogeton.

Abundant.

Swimming Potamogeton.

Common.

Various-leaved Potamogeton. Shallow ponds and borders of lakes. Head of Seneca lake, Gray. Common.
Water-plantains.

Arrow-grasses. Marsh Triglochin.

TRIGLOCHIN, $L$.

PALUSTRE, $L$. Boggy borders of Onondaga lake; at Salina, and northward beyond Liver-
pool. Abundant in water-covered places of moss or marl, in the West Bergen swamp, Genesee county.

Rare. June - August. 
MARITIMUM, $L$.

Seaside Triglochin.

Banks round Onondaga lake. most abundant on the south and east sides. Bogs in the swamp of West-Bergen.

Rare. July - September.

EI.ATUM, Nuttall.

Tall Triglorhin.

Cold high marshes among the hill-tops of the range south of the Mohawk valley. Most abundant at Mud lake, in the tamarack swamps near Jordanville, on the State marsh and Hidden lake, south Herkimer county.

More lofty than the largest of the preceding species, sometimes nearly four feet in height,

Rare, June - September.

SCHEUCHZERIA, $L$.

PALUSTRIS, $L$.

Scheuc?zeria.

Moss swamps. Summit lake. Mud lake. Hidden lake. Wetmore's pond, Frankfort hill. Bog near Oriskany. Abundant in the swamps of Rome. Common in the marshes of the northern part of the county, Point of Rock lake, North pond, and the north woods.

May.

ALISMA, $L$.

Plantago, $L_{\text {, }}$, var. AMERICANUM, Gray. Ditches, bogs.

SAGITTARIA, $L$

VARIABILIS, Engelmann.

Low grounds, water-sides : with manifold variations.

heterophylla, Pursh.

Muddy banks.

Graminea, Michaux.
Common. July, August.

Water Plantain.

American Alisma.

Common. July, August.

Arrowheads.

Variable-leaved Sagittaria.

Differing-leaved Sagittaria.

Frequent.

Grass-leaved Sagittaria.

Shores of streams, ponds. Banks of Oriskany creek. Borders of Oneidla lake, Knieskern. Abundant along the outlet of the Eight lakes, north Herkimer county; and on Fourth lake it grows deeply submerged, in parches over the sandy bottom, having only short triangular leaves. Scarce. July, August.

\section{HYDROCHARIDACEA.}

LIMNOBIUM, Richard. SPONGIA, Richard.
Frogbits.

American Frog's-bit. Spongy-leaved Limnobium.

\section{Local. August.}

ANACHARIS, Richard.

CANAdENsis, Planchon.

Water-moss.

Canadian Anacharis.

Still water; brooks, rivers, lakes. Otsego lake. Canaderaga lake and its outlet. Throughout the Mohawk, in side-waters of the stream. Lake Ontario and the St.Lawrence river, flowering abundantly and beautifully at Alexandria bay.

Common. August.

VALLISNERIA, Micheli. SPIRALIS, $L$.

Tape-grass. Spiral-scaped Vallisneria.

Rivers and slow streams. Abundant in the Mohawk river. Outlet of Canaderaga lake. Occasional in the Chenango canal. Outlet of Crooked lake, Sartwell.

Uncommon. August. 
ORCHIDACE E.

Orchids,

ORCHIS, $L$.

SPECTABILIS, $L$.

Showy Orchis.

Damp rich woods.

Common. May.

GYMNADENIA, $R$. Brown.

TRIDENTATA, Lindley.

Shady swamps.

Three-toothed-lipped Gymnadenia.

Abundant. July.

PLATANTHERA, Richard.

oвTUSATA, Lindl.

Obtuse-leaved Platanthera.

Mossy springy banks in the north woods, between Third lake and Bald rock,

Herkimer county.

Rare. July.

ROTUNDIFoLrA, Lindley.

var. OBLONGIFOLIA.
Round-leaved Platanthera.

Oblong-leaved Platanthera.

Upland, open, sphagnous level at the head of Mud lake, south Herkimer county; under scattered tamaracks and arbor vitæ, either among clusters of the young evergreens or in shade of their north side, in cold damp moss: accompanied by Calypso borealis, Cypripedium arietinum, Eriophorum alpinum. To be looked for on the extensive tamarack swamps south of Jordanville.

Roots three or four long toothed tubers: scape six to twelve inches high : leaf resting on the moss or settled in it, white cellular beneath as those of $P$. orbiculata, about ten-nerved, long elliptical or oblong, two inches broad by four to six in length; radical scapeless leaves still narrower, less than half as wide : spikes six- to twelve-flowered, bracts nearly as long as the ovaries : flowers large, lateral sepals spreading nearly three-fourths of an inch : spur shorter than the lip, slender, lying close to the capsule : lip balf an inch long, sometimes oblong or rectangular and entire, with a wavy border, but usually more or less parted into lateral lobes and notehed at the end, white with eight or ten purple spots : petals narrow, converging over the column, deep purple: lower sepals long ovate, white; upper one broad ovate, either curving over the petals or sometimes reflexed, veined and tinged with purple. A plant as beautiful as it is rare.

It has been found before only in Newfoundland, Isle of Anticosti at the mouth of the St.Lawrence, along the northeastern boundaries of Maine, and in the northern Rocky mountains; so that its presence south of latitude $43^{\circ}$ is most remarkable.

Local. June, July.

orbicULATA, Lindley.

Orbicular-leaved Platanthera.

Deep damp woods. Throughout the valley of the Mohawk. About Otsego lake, Miss S. Cooper: B.D. Gilbert. Most frequent on Frankfort hill, and among the headwaters of the Deerfield creek. Oriskany valley; Oriskany, Manchester, Clinton and College hill. Abundant in the north woods. Widely scattered, but scarce.

July.

\section{HOOKERI, Lindl.}

Dedicated to WILLIAM J. HookeR.

Dry woods. Littlefalls, bushy cleared land on the summit of Fall hill, south of the Mohawk. Dense woods along hillsides east of Utica and Oriskany, Knieskern. Sandy evergreen-wooded ridges southwest of Whitesboro. Pine barrens along Wood creek, near New-London : abundant in Jefferson county, Gray. Scarce.

var. obLONGIFoliA. Oblong-leaved Hooker's Platanthera. Steep banks of Fall hill at Littiefalls, between the tops of the cliffs and the brow of the high land.

Leaves four to six inches in length by two wide, narrowing toward the base into a clasping sheath, as in the var. of $P$. rotundifolia. Local, June. 
BRACTEATA, Torrey.

Long-bracted Platanthera.

Damp or wet woods. Along the Rolleboom of the Rotterdam hills, Schencetady county. Fairfield, IIerkimer county, Gray $i n$ Rare plants of Northern $\boldsymbol{N} . \dot{\boldsymbol{Y}}$. Frankfort hill. Not rare in southern Oneida county, Sangerfield; and Madison county, Brookfield, Gray. Yates county, Sartwell in herb. Ham. Coll.

HYPERBOREA, Lindl. Infrequent. June.

Shady swamps.

Northern Platanthera.

Common. July.

dilatata, Lindl.

Dilated-lipped Platanthera.

Cold marshes. Summit lake, Otsego county. Common at Mud lake, in the Jordanville swamps, on Hidden lake and the State marsh, south Herkimer county. Wet banks of Fish creek. Level borders of Point of Rock lake; and in all the sphagnum bogs of the northern part of the county. Throughout the north woods and the northern portion of the State.

Abundant. June - August.

FLAVA, Gray.

Wet woods, borders of swamps.

CILIARIS, Lindl. Wenst of Albany, Beck bot. Pine plains of Schenectady, Pearson. Junius, Seneca county, Surtwell in herb. Ham. Coll. Greece and Parma, Monroe county, Bradley.

BLEPHARIGLOTTIS, Lindl. Infrequent. June, July.

Lash-lipped Platanthera.

Sphagnous swamps. Frankfort hill, around Wetmore's poud. South Trenton. Borders of Point of Rock lake. Two and three feet high.

Rare.

var. Holopetala, Gray.

Entire-petaled Platanthera.

Open moss bogs of the north woods, a foot or less in height : frequent there, but not ołserved south of North pond, Boonville.

July.

LACERA, Gray.

Wet meadows, streams, swamps.

PSTCODEs, Gray.

Swampy woods, and meadows.

Butterfly-like-lipped Platanthera. Common. July, August.

Fimbriata, Lindl. Soldier's-plume. Fringed-lipped Platanthera. Cold swamps. Delaware county, B.D.Gilbert. Otsego county, Miss S, Cooper. Marshes of northern Herkimer county, W. Calverly. Shady swamp west of Fort Bull, Rome.

In all respects, of character, size and time of flowering, the same as the eastern form.

Rare. June.

\section{GOODYERA, R. Brown.}

REPENS, $R . B r$.

\section{Rattlesnake Plantains.}

Creeping Goodyera.

Dry ridges of ravines and their mossy sides, in the shade of hemlocks. Deerficld creek. Starch-factory creek. Cascade glen. South side of Point of hock lake.

Rarely it is found in Cedar swamps, from Mud lake, where it grows side by side with Calypso borealis, throngh similar localities on bot the hills and flats of the Mohawk, to the cold boggy woods of Rome. Common in southern Oneida county. Gray.

The same in size and character with the White mountain plant.

Frequent. July, August.

\section{PUBESCENS, $R$. Br.}

\section{Pubescent-spiked Goodyera.}

Damp shaded hillsides. Schenectady county, Pearson. Otsego county, B. D. Gilbert. Schuyler hill, above Frankfort station. Banks of Oriskany creck, Pleasant valley.

Abundant. July. 
Hillsides, dry open woods. Sides of the Mohawk valley from Schenectady to Littlefalls. Pine plains of Rome, Knieskern. Around Oneida lake, Gray. Banks of the hill near the old fort, Oswego. Oak openings, Greece, Monroe county, Bradley.

Frequent. July, August.

LATifolia, Torrey.

Broad-leaved: Spiranthes.

Springy, grassy banks. Banks of West-Canada creek, Fairfeld, Herkimer county, Gray. Oriskany, at the head of the raceway, along the sidehill. Opposite the village, on the north side of the Mohawk, scattered over the wet slope. Springy banks at the headwaters of Frankfort creek, between Wetmore's and Jerusalem hill. Rocky island in Black river, Rutland, Jefferson county, J.G. Crocker.

Rare. June.

CERNUA, Richard.

Nodding Spiranthes.

Marshes and wet meadows.

Abundant. August, September.

LISTERA, $R$. Brown.

CORDATA, R. Br.

Twayblade.

Swamps, in wet moss and deep shade. Mud and Hidden lakes, south Herkimer county. Cedar swamps on the flats of the Mohawk, and the pine swamps beyond Rome. Paris hill swamp. Southern part of the county, Gray.

Abundant. May, June.

ARETHUSA, Gronovius.

Arethusa.

BULBOSA, $L$.

Bulbous Arethusa.

Sphagnum marshes. Major Van Voost's fly, Schenectady, Pearson. Formerly on the flats of the Mohawk below Utica, and in the Oriskany swamp, Gray. In the extensive moss marsh beyond Fort Bull, and doubtless occasional throughout the swamps of Rome. Junius, Seneca county, Sartwell in herb. Hum. Coll. Borders of the West-Bergen swamp.

Rare. May.

POGONIA, Jussieu.

Pogonias.

OPHIOGLOSSOIDES, Nuttall.

Swamps of sphagnum.

Ophioglossum-like Pogonia.

A monstrosity of this plant has been gathered on Hidden lake, south Herkimer county. Several flowers were found, all having many petals nearly white, around three lips also white veined with purple, except their centers, which were covered with a heavy deep green beard.

The peculiarities of these flowers are that they have three labella, and that the column is resolved into small petaloid organs. The blossom is normal as to the proper perianth, except that the labellum is unusually papillose, bearded almost to the base. The points of interest are, first, that the two accessory labella are just in the position of the two suppressed stamens of the outer series, viz. of $A^{2}$ and $A^{3}$, as represented in the diagram (DARwIN, Fertilization of Orchids, p. 292); and there is a small petaloid body on the other side of the flower, answering to the other stamen $A^{1}$. Secondly, in one of the blossoms, and less distinctly in another, two lateral stamens of the inner series, $a^{1}$ and $a^{2}$, are represented each by a slender naked filament. There are remaining petaloid bodies enough to answer for the third stamen of the inner series and for the stigmas, Gray in Linn. Soc. Jour. Also Sill. Jour.

Thus these developments, in some measure, reveal the complete or regular orchid structure. June, July.

PENDULA, Lindl.

Pendulous-flowered Pogonia.

Damp woods in rich mould. Pine plains of Rome, Knieskern. Eaton, Madison county, on the hill south of Leland's upper pond, Bradley. Sheldrake point, Cayuga lake, Gray. Gorham, Ontario county, Sartwell in herb. Ham. Coll. Geneva, J. Smith fide Carey in herb. Sartwell Ham. Coll. Parma, Monroe county, Bradley. 
VERTICILLATA, Nutt.

Whorled-leaved Pogonia.

Shady swamps. Schenectady, in the pine plains, Pearson. Oriskany swamp,

Vusey. Mossy bogs on the plains of Rome, along the Watertown railroad. Rare. May.

CALOPOGON, R. Brown.

Calopogon. PULCHELLUS, R. Br. Elegant Calopogon.

Sphagnous marshes. Common.

White flower's occur in the swamp of West-Bergen, Genesee county.

Rare. July.

CALYPSO, Salisbury. BOREALIs, Salisb.

Calypso.

Northern Calypso.

Rich black soil on elevations in the arbor-vitie swamp of Mud lake, south Herkimer county : probably the sonthern limit of the plant.

From a swamp a mile or two north of Lowville, Lewis county, gathered by a party of students, $F$. B. Hough. In evergreen woods along the north side of Black river below Brownville, Vasey. In both these localities plants were gathered many years ago, but have not been detected since, in either place, by most diligent search.

Hemlock woods bordering the extensive swamp in $\Pi$ est-Bergen, Genesee county, C.M. Booth.

Rare. May, June.

TIPULARIA, Nuttall.

DISCOLOR, Nutt.

Cranefly Orchis.

Open woods on the Ridge-side, Parma, Monroe county, Bradley.

Rare. July.

MICROSTYLIS, Nuttall.

MONOPHYLLOS, Lindley.

Adder's-mouth.

Single-leaved Microstylis.

Shady bogs. Tamarack swamps between Jordanville and Page's corners, south Herkimer county. Bridgewater. Gray in Rare plants of Northern N.Y. Between Clark's mills and New-York mills. Cedar swamp near the Chenango canal, three miles southwest of Utica. Shady borders of Hidden lake. Litchfield. Borders of West-Bergen swamp.

Rare. July.

LIPARIS, Richard.

LILIIFOLIA, Richard.

Twablade.

Rich woods, banks of streams in shade. Pearon. Veron, Schenectady county, Seneca county, Brewer et Chickering in herb. Sartwell Ham. Coll.

Scarce. June.

LESELII, Richard.

In honor of JOHN LESEL.

Water-sides, marshes. Borders of Mud lake; on the swamps near Jordanville; abundant in the shady borders and on the open marsh of Hidden lake; and wet banks of Cedar lake, south Herkimer county. Northwestern part of county, about Oneida lake, Gray. Rivulet-sides on the borders of the swamp in West-Bergen, Genesee county. Frequent. June, July.

CORALLORHIZA, Haller.

INNATA, $R . B r$.

Coral-roots.

Spurless Corallorhiza.

Wet moss in deep swamps, rarely in moist woods. Trenton falls. Cedar swanıs on the flats of the Mohawk between Utica and Frankfort. Marsb on Starch-factory creek east of Utica. Swamps west of Whitesboro. Paris hill. Hidden lake borders. Tamarack marshes of Jordanville. Mud-lake moss swamp.

Frequent. May, June

MULTIFLORA, Nutt.

Many-flowered Corallorhiza.

Dry woods.

Abundant. August 
ODONTORHIZA, Nutt.

Tooth-rooted Corallorhiza.

Deep rich woods. Otsego county, B. D. Gilbert. Ravine bottoms among the head streams of Deerfield creek.

Infrequent. July.

APLECTRUM, Nuttall.

Adam-and-Eve.

HYEMALE, Nutt.

Winter-lasting Aplectrum.

Damp woods in deep soil. College hill, Clinton. Foster's grore, New-Hartford. Woods on the Chenango canal, three miles southwest of Utica. Oriskany, Knieskern. Auburn, Cayuga county, I. H. Hall. Rochester, C.Dewey.

Scarce. May.

\section{CYPRIPEDIUM, $L$.}

PUBESCENS, Willd.

Rich oak woodlands; cedar and black ash swamps.
Lady's-stippers. Cypripedia. Downy Cypripedium.

Common. May.

PARVIFLORUM, Salisb.

Small-flowered Cypripedium.

Deep damp woods. Low woods on the flats of Oriskany creek, between Clinton and Manchester. Mohawk flats above Frankfort. Cedar swamp between Day's corners and Cedar lake, Litchfield; also the State marsh, Jerusalem, Herkimer county. Infrequent. May.

On the Rolle-boom of the Rotterdam hills, Schenectady county, a specimen has been gathered, having all parts of the flower single. except the lip, which is double. The two sacs are perfect, equal in form and of the usual size, with complete orifices; distinet above, the two inside margins keeping separate to the very point of attachment, the point of the sterile anther lying between them; but below, they adhere about one-third their length. Lower sepal entire.

June.

\section{CANDIDUM, Muhl.}

White-flowered Cypripedium.

Damp borders of streams and swamps.

Near Cooperstown, Otsego county, Horace Lathrop. The specimen in the possession of Dr. LATHRop, gathered a few years ago, certainly has the form of this species; and he aftirms that when growing, the flower was pure white.

And that its rauge commences in this part of the State, is not improbable. It ought to be looked for through the northern valler of the Susquehanna, and on the high marshes of its headwaters in south Herkimer county. The tamarack swamps south of Jordanville are almost identical in character with its habitat in the western part of the State, and contain many plarts its companions there, including Parnassia caroliniana and Valeriana sylvatica.

On the open marsh of the Bergen swamp, Genesee county, but more abundant along the edges of low woods bordering; where it was first found by C. M. Booth and G.T. Fish.

Rare. May.

SPECTABILE, Swartz.

Showy Cypripedium.

Cold swamps. Summit lake in the cedar woods at its head, Oisego county. Abundant in the marshes of Mud lake, Jordanrille, Hidden lake, the State marsh, and cedar swamps on the flats of the Mohawk below Utica, south Herkimer county. Trenton falls, on the springy bank opposite the High falls; and in swamps on the road to Utica. Between Oriskany and Rome. Swamp on Paris hill.

In the last locality, and at Mud lake, the flowers are pure white frequently. Infrequent. July.

\section{ACAULE, Aiton.}

\section{Stemless Cypripedium.}

Sandy woods and swamps. Throughout Schenectady, Montgomery and Otsego counties. Tamarack marshes between Page's corners and Jordanville : Frankfort hill, south Herkimer county. Paris hill swamp. Common on the plains of Rome and Oneida lake. Above the cliffs along Fish creek. Sandy woods in South-Trenton, and in the groves of Trenton falls. Abundant in the northern part of the county, Lewis county, and the north woods.

Flowers white, near Cooperstown, Otsego county, Mrs. J. Shaw.

Frequent.

Rare. June. 
ARIETINUM, $R . B r$.

Ram's-head Cypripedium.

Cold swamp̣s, in nuoss and deep black soil. Summit lake. Otsego county, in the half-opens sphagnum bog-land adjoining, within clumps of low tamaracks and arbor vite, or in their shade. In similar stations at Mud lake; bot most almulant on tle tamarack marshes near Jordanville, on the road to kichfield springs, Iferkimer cunnty. Lsually growing singly or two or three together, but often in clusters of ten to twenty stems. Stenis empressed, enclosed by three sheaths at base, clothed with minute down, knotted at the hases of leaves, twisted so that the leaves appear on all sides and not in opposite ranks as in other species. Leaves three to six, ciliate, smooth above and silrery-cellular beneath. Flower-bract large, ovate, leaf-like.

This species, which has proved to be so rare and transitory, in these stations appears both plenty and permanent. This is the more remarkable, because occurring so far south; the plant being a northern one, and this hatitat one of its limits southward.

Formerly, it has been found along the Rolle-boom near the Platte-kill, Schenectady county, by Pearson; and near Oneida lake, by Gray; but the plants have disappeared, or the stations are lost.

Rare. May.

\section{AMARYLLIDACEA.}

HYPOXYS, $L$.

E1. ECTA, $L$.

Borders of woods, damp grass lands.

IRIDACE E.

IRIS, $L$.

VERSICOLOR, $L$.

Bogs and wet meadows.

VIRGINICA, $L$.

Borders of marshes. Troy, Beck in herb.

SISYRINCHIUM, ${ }^{\circledR} L$.

Bermidiana, L., var. Anceps, Gray. Sword-spathed Sisyrinchium.

Waysides, pastures, meadows:

Common. May - July.

\section{DIOSCOREACE $A$.}

DIOSCOREA, Plumier.

VILLOSA, $L$.

Wet woods and thickets. Low sandy woods near Owasco lake, Cayuga county, I. H. Hall.

SMIILACEA.

Smilaces.

SMILAX, Tournefort. ROTUNDIFOLIA, $L$.

Woods, thickets, near water. Schenectady county, E.W. Paige. Oneida county, Knieskern. Penn-Yan, Sartwell. Rochester, C. Dewey.

Uncommon. June.

\section{HISPIDA, Muhlenberg.}

Prickly Smilax.

Low woods, shady swamps. Oriskany valley; wet woods between Clinton and Manchester; southeast of Clark's mills. In all damp thickets, and swamps on the flats of the Mohawk. Gorham, Seneca county, Sartwell.

Frequent. June.

HERBACEA, $L$.

Shaded banks of streams.
Herbaceous Smilax.

Uncommon. June. 
TRILLIUM, $L$.

Trillia.

SESSILE, $L$.

Sessile-flowered Trillium.

Rich woodlands. Near Irondequoit bay, Monroe county, L. Holzer.

CERNUUM, $L$.

Rare. May.

Nodding Trillium.

Shady banks. Schenectady county, Pearson: Paige. Otsego county, $H$.

Lathrop.

ERECTUM; $L$.

Ravines and moist banks.

var. Album, Pursh.
Scarce. May.

Purple, Erect Trillium.

Common.

White Trillium.

Valley of the Mohawk throughout: Frankfort: Utica. Valley of the Saquoit: New-Hartford. Valley of the Oriskany: Clinton: Lairdsville. Abundant.

var. FLAVUM, Eaton.

Yellow Trillium.

Southern part of Lewis county, J.G. Crocker. Occasionally, with the normal form, in the vicinity of Utica. Banks of the Mohawk at Rome, Vasey. Hamilton, Madison county, and Norwich, Chenango county, J. S. Douglass, Torrey Fl. N.Y.

Scarce. May.

GRANDIFLORUM, Salisbury.

Great-flowered Trillium.

Woods, cedar swamps, banks of streams. Abundant throughout the Mohawk valley. Frequent in the Sauquoit and Oriskany vallies.

May.

ERTTHROCARPUM, Michaux.

Red-fruited Trillium.

Evergreen woods, open banks. Schenectady county, Pearson. Otsego county, Miss S. Cooper. Trenton falls. Banks of the Deerfield creek. Brows of the Starch-factory ravine. Frankfort hill. Paris hill. Sides of Oriskany creek, Pleasant valley. Common throughout the sandy woods of Rome. Valley of the Unadilla, Gray.

Abundant. May.

MEDEOLA, Gronovius.

VIRGINICA, $L$.

Moist woods.

Cucumber-root. Virginian Medeola. Common. June.

\section{LILIACEA.}

Lilies.

ASPARAGUS, $L$.

OF FICIN.ALE, L.

Pastures, ravines. Escapes frequently.

Officinal Asparagus.

June.

POLYGONATUM, Tournefort.

BIFLORUM, Elliott.

Ravine-sides, moist woods.

Giganteum, Dietrich.

Solomon's-seals. Polygonata. Twin-flowered Polygonatum.

Abundant. May.

Banks of the Mohawk river, where it is common; but out of the valley it rare. Along Wood creek sparingly.

SMILACINA, Desfontaines.

raCemosa, Desf.

Woods, thickets, hillsides.

June, July.

Stellata, Desf.

Smilacinas.

Racemed Smilacina.

Common. May, June.

Starry Smilacina.

Abundant on the banks of the Mohawk. Wood creek. Fish creek, Knieskern. In all arbor-vitæ swamps on the hills, from Summit lake westward to Hidden lake.

Frequent. June. 
TRIFOLIA, Desf.

Three-leaved Smilacina.

Swamps. Summit lake. Mud lake. Jordanville marshes. Frankfort hill, round Wetmore's pond. Paris hill. Southeast of Oriskany. South Trenton. Abundant in the swamps of Rome. Borders of Point of Ruck lake. Common in the cold marshes of the north woods.

Abundant. May.

BIFOLIA, Ker.

Two-leaved Smilacina.

Woods.

Common. May.

CLINTONIA, Rafinesque.

BOREALIS, Raf.

Wild Lily of the Valley. Clintonia.

Northern Clintonia.

Damp woods, and in all arbor-vita swamps. Cold marshes and borders of ponds on the hills, from Otsego county, through the high swamps of Warren and Litchfield to Cedar lake, south Herkimer eounty. Paris hill, and over the uplands of the southern part of the county. Cedar swamps on the flats of the Mohawk; between East-Canada ereek and Littlef ılls; below $\varepsilon$ nd above Frankfort; ravines near Utica; south of Whitesboro; west of Oriskany; north of Rome. Swamps west of Rome and around Oneida lake. About Point of Rock lake. Evergreen woods of South-Trenton. Sides of North pond. Common in the north woods.

Abundant. May, June.

HEMEROCALLIS, $L$.

FULVA, L.

Roadsides; garden fences.

Day-lily. Fulvous Hemerocallis. Occasional. July.

ALLIUM, $L$.

Leeks. TRICOCCUM, Aiton.

Three-seeded Allium.

Moist woods.

Common. June.

CERnuUM, Roth.

Drooping-flowered Allium.

Damp banks. Seneca county, shores of the lake, Gray. Chemung valley, Knieskern, Torrey Fl. N.Y. Chemung county, Surtwell in herb. Hum. Coll.

Rare. July, August.

VINEALE, L.

Vineyard Allium.

Low meadows. Troy, Aiken in herb. Sartwell Ham.Coll. Schenectady county, Pearson: Paige. Near Utica, Knieskern in cat.

CANADENSE, Kalm.

Rare. June.

Water-sides. Sander's lake near Schenectady, Pearson. Shady woods, Oneida county, Knieskern. Meadows on the flats of the Mohawk opposite Whitesboro. Uncommon. May, June.

LILIUM, $L$.

Lilies. PHILADELPHICUM, $L$. Red Lily.

Plains, banks, bushes. Schenectady. Littlefalls. Rome. Abundant. June.

CANADENSE, $L$.

Yellow Lily.

Wet meadows, borders of swamps. Pine plains of Schenectady. Otsego county, Miss $S$. Cooper. Trenton falls, on the west bank opposite the High falls. Oneida county, Knieskern. Meadows of the Mohawk. Sandy woods of Rome. Yates county, Sartwell in herb. Ham. Coll. Frequent. June, July.

SUPERBUM, $L$.

Low meadows and swamps.

ERYTHRONIUM, $L$. AMERICANOM, Smith.

Damp woods and meadows.
Turk's-cap. Superb Lily.

Common. July, August. 
ALBIDUM, Nuttall.

White Erythronium.

Wet meadows. Near Albany, Eaton bot. Albany, Torrey Fl.N.Y.: in herb. Sartwell Ham. Coll. Delaware county, common, B. D. Gilbert.

Rare. April, May.

MELANTHACE E.

Melanthia.

UVULARIA, $L$.

GraNDIFLORA, Smith.

Flats of streams, damp woods.

Bellworts.

Large-flowered Uvularia. Common. May.

PERFOLIATA, $L$.

Small-flowered Uvularia.

Gulf-sides, borders of thickets. Ravines on the Deerfield hills. Frankfort hill. Headwaters of the Sauquoit creek; of the Unadilla river; and southward.

Infrequent. May.

SESSILIFOLIA, $L$.

Woods.

PROSARTES, Don.

LANUGINOSA, Don.

Rich open woods about Oriskany, Knieskern. Auburn, Cayuga county, $J$. Carey in herb. Sartwell Harn. Coll. Penn-Yan, Yates county, Sartwell. Near Rochester, Eaton bot.: Z. H. Harris, Torrey Fl. N. Y.: C. M. Booth. Greece, Monroe county, Bradley.

STREPTOPUS, Michaux.

AMPLEXIFOLIUS, $D C$.

Stem-clasping Streptopus.

Cedar swamps. Fairfield, Hadley, Torrey Fl. N.Y. In most of the swamps on the heights of Frankfort, near the Graefenberg Watercure; and Litchfield, Gray. Paris hill.

Rare. June.

Roseus, Michx.

Ravines and woods.

Rosy-flowered Streptopus. Common. May.

\section{ZYGADENUS, Michaux.}

GLAUCUs, Nuttall.

Glaucous Zygadenus.

On the gravelly banks of the St. Lawrence, in calcareous soil, Nuttall. Abundant in the marly portions of the West-Bergen swamp, northeastern Genesee county, chietly in the shade of evergreens and throughout the arbor vitæ bordering the marsh : discovered by G.T.Fish.

Rare. July.

VERATRUM, Tournefort.

VIRIDE, Aiton.

Wet meadows and swamps.

American Hellebore. Green-flowered Veratrum. Common. June.

CHAM ÆLIRIUM, Willdenow. LUTEUM, Gray.

Blazing-star. Light-yellow-flowered Chamclirium.

Meadows and low woodlands. Wet places in sandy woods near Owasco lake, Cayuga county, I. H. Hall. Yates county, Sartwell in herb. Ham. Coll. Rochester, Z. H. Harris in herb. Bradley.

Rare. May, June.

TOFIELDIA, Hudson.

False Asphodel. GLUTrNosA, Willd.

Glutinous-stemmed Tofieldia.

Wet moss and shallow bogs on the swamp of West-Bergen, Genesee county. In these moist stations, the plants are large and abundant; but sometimes they are found in nearly dry marly mud, in company with Scleria verticillata and Carex crawei, when they are dwarfed in size, flowering at the height of three to six inches. 
JUNCACEA.

LUZULA, $D C$.

Wood-rushes.

PILOSA, Willd.

Hairy Luzula.

Damp shady hanks of streams. Alnng Wood creck and near Oneida lake, Knieskern. Abundant on the wooded flats and rocky sides of Fish ereek. Yates county, Sartwell in herb. Ham. Coll.

Abundant. May.

CAMPESTRIS, $D C$.

Field Luzula.

Dry woodlands.

Common. May.

JUNCUS, $L$.

EFFUSUS, $L$.

Rushes. Junci.

Ditches, low meadows.

Effuse Juncus.

Common. June.

FILIFORMIS, $L$.

Filiform Juncus.

Sandy shores of lakes in the north woods. Head of Oneida lake, Gray. Lake Ontario near Sackett's-harbor, Gray in Rare plants of Northern N.Y.

Rare. July.

BALTICUS, Willd.

Baltic Sea Juncus.

Gravelly shores of the St.Lawrence and of Lake Ontario, Torrey $F l . N . Y$. Lake shore, Sackett's-harbor, Knieskern.

Common in the muddy portions of the swamp in West-Bergen, northeastern Genesee cuunty.

This plant appears out of place here. Its usual habitat is the border of the Lake; while this station is three hundred fuet or more above the level of the Lake, and nearly twenty miles south of the shore and has been found still farther inland. Other shore plants accompany it ; Scirpus torreyi, $Z y$ gadenus glaucus, Solidago houghtonii of which only one other station is known, on the northern shore of Lake Michigan : all depend on the water of the Lake for their establishment. Their presence at this place, therefore, indicates that the surface of the water has been so much higher, or the land so much lower, at some time past.

Furthermore, this is a seaside plant, native in the north of Europe and on our northern coasts. For its introduction to the Great Lakes, it is just as dependent on the ocean as are Ranunculus cymbalaria, Atriplex hastaia, Saliconia herbacea, Najas major, Ruppia maritima, Triglochin maritimum, J.bulbosus, Scirpus maritimus and spartina stricta for their existence at Onondaga lake, and Lathyrus maritimus on the beaches of Oneida lake. These localities are all nearly on the same level, which must have been the shore of a maritime bay, during some ancient period. This period cannot have been less remote than the Post-tertiary, and may have been among the epochs of the Tertiary itself.

So these stations prove these very species of plants to be very old; and because still identical in character, both inland and on the coast, that they have not varied in the least during so many ages and so great changes.

Rare. July.

SCIRPOIDES, Lamarck.

Scirpus-like Juncus.

Borders of ponds and streams. Low sandy points of lakes in the morth woods. Shores of North pond near Alder creak. Shores of Lake Ontario, near Sackett's-harbor, Gray in Rave plants of Northern $\boldsymbol{N} . \boldsymbol{Y}$. Reoccurring on the hills south of the Mohawk valley. Along Canaderaga lake outlet, Otsego comnty. Southern Oneida and Madison counties, Gray. Iitt's county, Sartwell in herb. Ham. Coll.

Frequent. July.

Paradoxus, Meyer.

Remarkable-fruited Juncus.

Wet banks of rivulets, grassy marshes, around swamps, lakes, and all water-courses.

Common. July; August. 
DEBILIS, Gray.

Weak-stemmed Juncus.

Muddy bottoms of shady swamps.

Its habit cleariy distinguishes this species; the stems lying flat on the ground, radiating in all directions from the root, nearly two fiet in length. Infiequent. August, September.

actirnatus, Michx.

Sharp-fruited Juncus.

Marshes. Common along low shores in the north woods. In the swamps of

Warren, south Herkimer county, between Jordanvilie and Richfield springs.

Oneida county, Knieskern. Jeffirson county, Vusey. Head of Seneca lake,

Gray. Crooked lake, Sartwell in herb. Ham. Coll. Frequent on the southern borders of Bergen swamp, Genesee county. Abuudant. July-September.

ARticulatus, $L$.

Articulate Juncus.

Water-sides. Dexter, Jefferson county, Vasey. Penn-Yan, Sartwell in herb. Har. Coll.

var. PELocarpus, Gray.

Brown-fruited Juncus.

Shores. Onondaga lake, on all sides, in shallow water. Banks of Genesee river near Avon; mouth of the Genesee, Sartwell in herb. Hum. Coll.

Rare. August.

NODOSUS, $L$.

Inotted-leaved Juncus.

Water-borders, muddy banks. North woods. Alder creek. Cedar lake, south Herkimer county. Onondaga lake.

Abundant. July.

var. MEGACEPHALUS, Torrey.

Great-headed Juncus.

Sandy shores of Lake Ontario, Gray, Torrey Fl. N.Y.: bot. Wet soil near the Lake shore, Monroe county, L. Holzer.

Rare. July.

CONBADI, Tuckerman.

Determined by CoNRAD.

Sandy shores. Albany, Beck in herb. Plentiful on the banks of Third and Fourth lakes, north Herkimer county; frequently viviparous. Rare. July.

STYGIUS, $L$ 。

Stygian Juncus.

In an extensive sphagnous swamp bordering Perch lake, Jefferson county; not previously known as a native of North America, Gray in Rare plants of Northern N.Y. Thirty years ago or so, it was found near the head of the lake, on a wet quaking bog which extended to the water. But the !ake has been raised at its outlet, or lowered; either of which would destroy the locality. Others have 1 ried for years, but have not rediscovered the plant, Gray.

Specimens were taken from this station also by Crawe: Wood: Vasey.

The heads are not always single and terminal : many specimens have two, one to three inches apart.

Local. July, August.

TENUIS, Willd.

Roadsides, damp grounds.

BUlbosus, L., var. Gerardi, Gray.

Rivulet-sides and wet banks, east of Salina and west of Onondaga lake, in thick patches. Common there.

BUFONIUS, $L$.

Ditches, shores.

\section{PONTEDERIACE E.}

PONTEDERIA, $L$.

CORDATA, $L$.
Slender Juncus.

Common. June.

Black-grass.
Toad Juncus. Common. August.

Pickerel-weeds.

Common Pickerel-weed. Shallow waters of lakes, ponds, rivers. Otsego lake, Miss S. Cooper. Lakes of the north woods. Oneida lake, Knieskern. Bays and inlets on Lake Ontario.

var. ANGUstifolia, Gray.

Frequent.

Narrow-leaved Pontederia.

Borders of Canaderaga lake, Otsego county, Gray. July - September.

[ON. Pr.] 
SCHOLLERA, Sihreber. GRAMINEA, Willd.

Water Star-grass. Grass-leaved Schollera.

Flowing water. Chenango canal, two miles southwest of Utica. Occasional in the Mohawk river throughout. Unadilla river common, Gray. Eaton Madison county, Bradley. Junius, Seneca county, Sartwell in herb. Ham. Coll. Genesee river and Irondequoit bay, C.M. Booth. Infrequent. August.

XYRIDACEA.

Xyrids.

XYRIS, $L$.

BULBosA, Kunth.

Yellow-eyed Grass. Bulbous Xyris.

Mudly edges of an elevated pond at the east end of Bald roek, north Herkimer county. Growing in clusters of many plants connected at the roots : very small in size, scapes two to six inches high, leaves one-half to two inches long.

Rare. July, August.

\section{ERIOCAULONACE E.}

Pipeworts.

\section{ERIOCAULON, $L$.}

SEPTANGULARE, Withering.

Seven-angled Eriocaulon.

Lakes and ponds of the north woods, throughout aud common. August.

\section{CYPERACE E.}

Sedges.

CYPERUS, $L$.

Cyperi.

DIANDRUS, Torrey.

var. CASTANEUS, Torr.

Two-stamened Cyperus.

Chestnut-colored Cyperus.

Wet pastures, Oneida county, Knieskern. Common in southern Oneida and Madison counties, Gray. Marshy banks at Salina, and sandy shores beyond Liverpool, Onondaga lake. Yates county, Sartwell. Monroe county, L. Holzer. Abundant. August, September.

MICHAUXIANUS, Schultes.

Discovered by Michaux.

Waterside marshes. Borders of Oneida lake, Knieskern. Salina, New-York, J. Carey, Torrey Cyp. Wet banks at the head and east side of Onondaga lake, but scarce. Shores of Lake Ontario: Oswego. Crooked lake, Sartwell. Rare. August.

STRIGOSUS, $L$.

Strigose-spiked Cyperus.

Stream-sides, low sandy grounds. Valley of the Mohawk throughout, on springy hillsides and gravelly banks. Whitesboro, on the barren sand from the break of the Erie canal. Borders of swamps on the plains of Rome. Around Onondaga lake.

Frequent. August.

INFLEXUs, Muhl.

Recurved-scaled Cyperü.

Sandy shores of rivers and lakes. Near Albany, Tracy and Eaton, Torrey Cyp. Near Oneida lake, Gray Gram \& Cyp. Shore of Oneida lake at the water's edge, a half mile north of F'ish creek, plenty, Knieskern.

Infrequent. August.

DENTATUS, Torr.

Dentate-spiked Cyperus.

Shores of Fourth lake in the chain of Eight, north Herkimer and Hamilton counties, on a sandy point of the north side, and at the head near the inlet from the upper lake: where it occurs in its abnormal state, with scales and spikes foliaceous.

Rare. August, September.

PHYMATODES, Muhl.

Many-tubered Cyperus.

Damp banks. Low alluvial bottoms in the bed of the Mohawk river throighout its length, but chiefly from Schenectady to Littlefalls; also in ditches and bogs over the flats. Shores of Oneida lake, Torr. Cyp. Avou springs, Livingston county, Sartwell in herb. Ham. Coll.

Common. August. 
SCHWEINITZI, Torrey.

Discovered by Schweinitz.

Dry sandy banks along the shore of Lake Ontario. Sodus bay, Sartwell in herb. Haim. Coll. Near Greece, Monroe county, Bradley, Torrey Cyp. Beach of Lake Ontario near Braddock's bay, Bradley.

FILICULMIS, Vahl. Rare. August.

Barren fields and bants. Abundant in the sandy wastes at the head of lake. South shore of Oneida lake, Knieskern. Around Onondaga lake.

Frequent. July, August.

\section{DULICHIUM, Richard.} SPATHACEUM, Persoon.

Sheathed Dulichium.

Marshes, borders of lakes, frequent. In the north woods, common. August.

\section{HEMICARPHA, Nees von Esenbeck.}

SUBSQUARrosa, Nees.

Spreading-scaled Hemicarpha.

Sandy shores. Northern parts of the State of New-York. Stevenson; western parts of the same State, Gray; Torrey Cyp. Near Onoida lake, New-York, Gray Gram.\& Cyp. Shore of Oneida lake above the mouth of Fish creek, with Cyperus inflexus, Knieskern. Rare. July.

ELEOCHARIS, $R$. Brown.

овтUsa, Schultes.

Obtuse-scaled Eleocharis.

Marshes, low grounds.

Common. July.

PALUSTRIS, $R$. Br.

Marsh Eleocharis.

Bogs, swamps, borders of ponds, lakes at the water's edge. Often very high when growing in shallow water.

var. oaliva, Gray.

Common. July.

Skull-spiked Eleocharis.

Western part of the State, Torrey Fl.N.Y. Watertown, Crawe, Gray bot.

August.

compressa, Sullivant.

Compressed-culmed Eleocharis.

Shallow borders of lakes, or at the water's edge, in the north woods. Wet mud-banks of a millpond at Cedarville, south Herkimer county. Brownville, Jefferson county, W. A. Wood in herb. Sartwell Hain. Coll. Scarce. August.

Rostellata, Torrey.

Rostrate-fruited Eleocharis.

Swamps. Junius, Seneca county, Sartwell, Torrey Cyp. and Fl. N.Y.: Gray bot.: in herb. Surtwell Hum. Coll. Common on the swamp of West-Bergen, Genesec county; in wet moss and water-covered marl.

This plant commonly bears fruitless culms two to four feet in length, wnich, bending over, root at the end.

$$
\text { August, September. }
$$

INTERMEDIA, Schultes.

Intermediate Eleocharis.

Damp banks and shores. Jefferson county, Crawe, and Oneida county, Gray, Torrey Cyp. Shores of North pond, southwest of Boonville. Near Oriskany, Knieskern. Cedarville, covering the muddy banks of a millpond, and along the creek towards Ilion; marly shores of Cedar lake, with Scirpus pauciflorus; south Herkimer county. Southern Oneida and Madison counties, Gray. Benton, Yates county, Sartwell in herb. Ham. Coll. Infrequent. August.

TENUIS, Schultes.

Slender Eleocharis.

Marshes. Mud lake, Jordanville, Cedar lake, Hidden lake, and Cedarville, south Herkimer county.

Frequent. August.

ACICULARIS, $R$. Br.

Needle Eleocharis.

Rivulet-sides, wet banks and bottoms of mud. Common. June - August. 
SCIRPLS, $L$.

CESPITOSUS, $\boldsymbol{L}$.

Scirpi.

Tufted Scirpus.

Sphagnous bogs on mountain tops, and cold swamps. Mount Marcy, Knieslern in herb. Sartwell Hum. Coll. Common on the West-Bergen marsh,

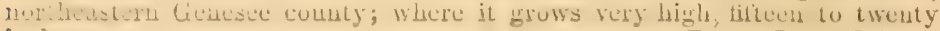
inches.

Rare. June, July.

PACCIFLORUS, Lightfoot.

Few-flowered Scirpus.

Marshes. Watertown near Lake Ontario, Crawe, Gray addend. bot. Hidden lake, Litchfield; where it abounds in the peculiar covering composed of Hypnum scorpioides, witl Curices chordorhiza, filformis and limosu chiefly: marly bogs around Cedar lake, most abundant on an old outlet of the pond, covering its surface : sonth Herkimer county. It also occurs very sparingly on the southern border of the swamp in Bergen, northeastern Genesee county, in marl mud.

Rare. July.

PLANIFOLIES, Muhl.

Flat-leaved Scirpus.

Rucky waxls and bugs. Ogdensburgh, St.Lawrence cunty, Cruwe. Torry Cyp.

Rare. June.

Clintonit, Gray.

Dedicated to G. W. Clinton.

Dry banks.

SCIRPUS PLANIFolius, Tar. brevifolius. Leaves much shorter than the culm, very narrow, canaliculate, triquetrous towards the summit; scales shorter and scarcely acuminate. Culm a foot long, rerv slender. Leaves scarcely half a line wide, $1-3$ inches long, almost subulate. Spike broadly ovate. Ogdensuurgh, N. York, Crace : Torrey Cyp.

Folio e vagina suprema involuto-filiformi culmo multum breviori, cæteris brev: imis vel subnullis; squamis capituli (preter infimam) carina vis prominula haud percurrente muticis; setis perigrnii achenium superantibus : rel. ut in S. planifolio: Gray in Sill. Jour. Rare. June.

stBTERMINALIs, Torrey.

Subterminal-fruited Scirpus.

Deep still water. Inlet of a stream on the west side of First lake, north Herkimer county. Sphagnum pond adjoining North pond, north Oneida co.

Rare. Alngust.

var. TERRESTRIS. Emersed Subterminal-fruited Scirpus.

Wet moss on Hidden lake, south Herkimer county. Standing ten to twenty inches high, with one to three or four erect strong leaves and open round heads of fruit. Local. Angust.

PUNGENS, Vahl.

Pointed Scirpus.

Lake borders, swamps. Shallow water of ponds in the north woods. Oneida lake, Knieskern. Western part of the State of New- Tork, Gray Gram.\& Cyp. Water-sides near Onondaga lake.

At Salina a small form occurs, short, slender, and few-flowered.

A bundant. August.

TORREYI, Olney.

Determined by TORREY.

Margins of rivers, ponds. Abundant near the head of Fourth lake, Hamilton county, along the south shore, in shallow water on sandy bottoms. Also in quantity orer the sontlern portion of the swanip of West-Bergen, Genesee county; in company with Juncus balticus and other Lake shore plants.

Rare. August.

LACCSTRIS, $L$.

Lake Scirpus.

Bogs, rivers, lakes.

Common. July.

DEBILIs, Pursh.

Weak Scirpus.

Sanily borders of lakes. Tret shores of Oneida lake, Knieskern. Shore of Isalke Ontario near Sacizett's-harbor, Now-York, Gray Grain.\& Cyp.: Torr. Cyp.: in herb. Sartwell Ham. Coll.

Rare. August. 
MARITIMTS, $L$.

Seaside Scirpus.

Beaches. shore-marshes. Sandy banks at Salina and of Onondaga lake: where all manner of forms abound, from a depauperate one and the smallest size, up to the ordinary and highest states.

Local iuland.

var. MACRostACHYos, Michaux.

Large-headed Scirpus.

Marshes of Salina at the head of the lake. Abundant here. but local.

August - October.

FLUVIATILIS, Gray.

River Scirpus.

Lake and river-marshes. Gravelly shores of Canaderaga lake. Otsego comnty ; where it was discovered hy Dr. GRAr in the year 1832. Borders of Oneida lake, Knieskern. Common in the western paris of the State of New-York, Gray, Torrey Cyp. Yates county, Sartwell in herb. Ham. Coll. Irondequoit bay of Lake Ontario, L. Holzer.

SYLVATICUS, $L$.

var. ATRovIRENS, Gray.

Low meadows, swamps.

POLYPHYLLUS, Vahl.

Terders of wet woods and thicket-swamps. Near Penn-Yan, Yates county: Lockport, Niagara county: Sartwell.

LINEATUS, Michx.

Swamps. Ontario county, Sartwell in herb. Ham. Coll. Rare. July.
Woodland Scirpus. Dark-green Scirpus. Common. July.
Many-leaved Scirpus. Rare. July.

\section{Line-scaled Scirpus.}

ERIOPHORUM, Michx.

Low grounds.

var. CYPERINUs, Gray.

Wool-bearing Scirpus. Common.

\section{Cyperus-like Scirpus.}

Wet places on Bald rock, north Herkimer county. var. LAxus, Gray.

Loose-fruiting Scirpus.

Marshes of the north woods. Borders of Oswego river. August.

\section{ERIOPHORUM, $L$.}

ALPINCM, $L$.

Cotton-grasses. Eriophora.

Alpine Eriophorum.

Cold moss marshes. Oriskany swamp: Knieskern: Gray: Vasey. Abundant on the extensive sphagnum swales beyond Rome, both sides of the Oswego county road. Tufts on the surface of Hiddeu lake, Litchfield; and on the borders of Mud lake; south Herkimer county. Rare. June.

VAGINATUM, $L$.

Sheathed-culmed Eriophorum.

Elerated swamps. Shaky sphagnum flats surrounding Tetmore's pond on Frankfort hill. Watertown and Utica, Gray, Torrey Cyp. Abundant in deep sphagnous swamps on the pine plaius six miles west of Rome. Rare. June.

\section{VIRGINICCM, $L$.}

Virginian Eriophorum.

Sphagnum bogs. Frankfort hill. Paris hill. Oriskany. Rome. South Trenton. Near North pond. Common in the north woods.

\section{POLTSTACHYON, $L$.}

Wet meadows, grassy bogs.

var. AnGUSTIFolium, Gray.

\section{Many-spiked Eriophorum.}

Common.

\section{Narrow-leaved Eriophorum.}

Cedar and moss-swamps. Western part of the State; Oriskany swamp; Brookfield, Madison countr; Gray. Sphagnum bog sontheast of Oriskauy, on the hill. North Herkimer county marshes, at the edges of woods.

Rare. July. 
GRACILE, Koch.

Slender Eriophorum.

Mossy marshes. Open grassy bog, north of Summit lake, Otsego county. Cedar swamp bordering Mud lake: abundant on Hidden lake; south Herkimer county. Common on cold bogs west of Fort Bull, Rome, near the Erie canal. Pools in the sphagnous marsh adjoining North pond. Wet banks and along brooks in the north woods.

Infrequent, June.

FIMBRISTYLIS, Vahl.

AUTUMnalis, Rom. \& Schultes.

Autumnal Fimbristylis.

River-sides. Troy and Schenectady, Pearson. Infrequent. August, Sept.

CAPILLARIS, Gray.

Capillary Fimbristylis.

Dry sand. Pine plains of Schenectady, E.W. Paige. Sandy plains of Oneida lake, Gray.

Uncommon. August, September.

RHYNCHOSPORA, Vahl.

Beaked Rushes.

FUSCA, Ram.\& Schultes.

Brown Rhynchospora.

Lake-shores and boggy margins of ponds in the north woods. Herkimer and Hamilton counties : abundant there.

August.

ALBA, Vahl.

White Rhynchospora.

Marshes. Summit lake. Mud lake. Frankfort hill. State marsh. Hidden lake. Oriskany swamp, Knieskern. North pond, off Alder creek; and in all the bogs of the north woods.

Cummon. August.

CAPILlaCeA, Torrey.

Capillary Rhynchospora.

Bogs and wet rocks. Cranberry marsh at the head of Oneida lake, Knieskern. On limestone rocks. Watertown, New-York, Gray Rhyn. Junius, Seneca county, Sartwell. Crevices and seats of the wet eliffs below the falls of Genesee river, Rochester. West-Bergen swamp, Genesce county.

A variety with twelve bristles is abundant on Hidden lake and the State marsh, Litchfield, south Herkimer county.

Rare. July, August.

GLOMERATA, Vahl.

Clustered Rhynchospora.

Mossy level adjoining an elevated pond at the east end of Bald rock, north of Third lake, north Herkimer county.

Rare. August.

\section{CLADIUM, Browne.}

MARISCOIDES, Torrey.

Marisus-Tike Cladium.

Marshes and lake-shores. Abundant on Hidden lake, Litchfield. Oriskany swamp, Gray: Knieskern. Common on borders of lakes and ponds in the north woods.

Infrequent. August.

\section{SCLERIA, $L$.}

TR IGL OMER ATA, Michaux.

Nut-rushes.

Swamps, low copses. Plains of Rome, Knieskern. Yates county, Sartwell. Infrequent. July.

PAUCIFLORA, Muhlenberg.

Few-flowered Scleria.

Wet meadows, hillsides. Greece, Monroe county, Bradley. Rare. July.

VERTICILLATA, Muhl.

Whorled-fruited Scleria.

Marshes. Junius, Seneca county, Sartwell, Torrey Cyp.: Gray Gram. \& Cyp.: in herb. Sartwell Ham. Coll. Abounding in the damp marl of the West-Bergen swamp, Genesee county.

The fresh plant has a peculiar and agreeable fragrance. Rare. August. 
CAREX, $L$.

Carices.

GYNOCRATES, Wormskjold.

Strong-pistilled Carex.

Swamps. Savannal, Wayne county, Sartwell in herb. Hum. Coll. Springy banks a few miles south of Rochester, west of the Genesee river, Deucey. Abundant in the swamp of West-Bergen, Genesee county, in moisture and shade, covering low mounds and deeaying logs.

Rare. June.

Exilis, Dewey.

Meagre-fruited Carex.

Elerated bogs. Marshy borders of a pond off the east end of Bald rock, north of Third lake, north Herkimer county.

STERILIS, Willdenow.

Rare. June, July.

lake. Sphagnous swamps between Rome and Oneida lake. West-Bergen,

Genesee county

Infrequent. June.

BROMOIDEs, Schkuhr.

Bromus-tike Carex.

Marshes, water-sides.

Common. May.

DISTICHA, Hudson.

var. SARTWELLI, Dewey.

Swamps. Junius, Seneca county, Sartwell.

Fruit not two-rowed.

DEcomposita, Muhlenberg.

Swamps. Junius, Seneca county, and Penn-Ian, Yates counts, Sartwell.

Rare. July.

\section{Prairea, Dewey.}

Prairie Carex.

Marshes on the hills south of the Mohawk ralley. In the open mossy bogland north of Summit lake, Otsego county. Edges of Mud lake; common on the tamarack swamps between Jordanville and Page's corners; abundant over the surface of Hidden lake; sparingly in the State swamp of Jerusalem hill, Litchfield; south Herkimer county. Yates county, Sartwell. West Bergen, Genesee county,

Rare. July.

\section{CEPHALOPHORA, Willd.}

Head-bearing Carex.

Copses, sandy fields. Borders of thickets, north side of the river opposite Whitesboro. Mohawk valley. Knieskern. Greece, Monroe county, Bradley. Frequent. May, June.

MUHLENBERGII, Schkuhr.

Discovered by MtrilenberG.

Rocky woods, fields. Valley of the Mohawk, Knieskern. Dry sandy hills near Irondequoit bay, L. Holzer. Braddock's bay, Monroe county, Bradley: Sartwell: Dewey.

Rare. Jnne.

\section{CHORDORHIZA, $L$.}

Cord-rooted Carex.

Cold swamps, lake and river borders. Hidden lake and Jerusalem marsh, abundant. Oriskany swamp, Knieskern. Junius, Seneca county, Sartwell. Boggy margins of lakes in the north woods, frequent. St.Lawrence river near Ogdensburgh, Crawe, Eaton bot.

Rare. July.

CEPHALOTDEA, Dewey.

Head-like Carex.

Fields and hedges. Banks of the Mohawk between Oriskany and Rome, Vasey. Penn-Yan, Sartwell in herb. Ham. Coll. Infrequent. June.

\section{sparganiotdes, Muhl.}

Wet meadows, low thickets.

ROSEA, Schkuhr.

Cedar swamps.

var. Radiata, Dewey.

Meadows and open woods.
Sparganium-like Carex.

Common. June.

Rose-like-headed Carex.

Abundant. June.

Radiate-fruited Carex.

Occasional, June. 
Retroflexa, Muhl.

Reflexed-fruited Carex.

Wet woods, moss marshes.

Frequent. June - August.

disperma, Dewey.

Two-seeded Carex.

Swamps, especially those of arbor vitæ; abundant in all. May, June.

VUlpinoideA, Michaux.

Fox-like Carex.

Ditches.

Common. June, July.

SCABRIOR, Sartwell.

Rougher Carex.

Wood-borders, copses. Penn-Yan, Yates conty, Sartwell. Rare. June, July.

Setacea, Dexey.

Awned-fruited Carex.

Moist banks. Abundant at the head of Hidden lake, Litchfield, south Her-

kimer county. Infrequent. June, July.

teretiuscula, Goodenough.

Rounder.headed Carex.

Swamps. Borders of Sumuit lake, and in the open marsh-land northward, Otsego county. Margins of Mud lake; in the State marsh; and on Hidden lake; sonth Herkimer county. Oriskany, Knieskern. Western part of the State, Gray Gram.\& Cyp. Penn-Yan, Sartwell. Frequent. June, July.

STIPATA, Muhl.

Wet meaiows.

ALOPECOIDEA, Tuckerman.

Grassy woods. Oneida county, Vasey. Yates county, Sartwell.

Rare. June, July.

STELlULATA, Good.

Deep swamps of cedar or sphagnum.

SCIRPOIDES, Schkuhr.

Arbor vitæ swamps.

CURTA, Good.

Crowded-spiked Carex.

Abundant. May; June.

Foxtail-like Carex.

Star-like Carex.

Common. June.

Scirpus-like Carex.

Frequent. May.

Short-fruited Carex.

Marshes. Frankfort hill, abundant around Wetmore's sphagnum pond. Oriskany. Rome. Swamps of the north woods. Frequent. June, July.

TENELLA, Ehrhart.

Slender Carex.

Bogs of Rome. Beyond Fort Bull, in low open woods. In the extensive swamp northwest of New-London, north side of Wood creek. Rare. June.

DEWEYANA, Schkuhr.

Discovered by DEwEY.

Shady ravines, damp woods. Around Mud lake, Warren: grove on the banks of Cedar lake, Litehfield: south Herkimer county. Rich bottoms of Starch-factory creek near Utica, and over the mossy sides of many deep ravines at its head. Shaded rocky banks of Fish creek, from Taberg northward.

Scarce. July.

TRISPERMA, Dewey.

Three-seeded Carex.

Cedar and sphagnum swamps. Frankfort hill. On the flats of the Mohawk below Utica. Near Oneida lake, Knieskern. South-Trenton. North woods. A bundant. July.

ARGYRANTHA, Tuckerman.

Silver-flowered Carex.

Borders of low woods near the sphagnum swale of South-Trenton.

Rare. June, July.

TENUIFLORA, Wahlenberg.

Small-flowered Carex

Open moss-swamp west of Fort Bull, Rome. south of the Erie canal, where it is abundant. Formerly in the Oriskany swamp, Vasey; but now all gone.

Rare. June. 
STRA MrNeA, Wahlenberg.

Swamps and their borders.
Siraw-colored Carex.

Frequent. May, June.

\section{Notable Carex.}

MrRABILIS, Dewey.

Wet meadows. Bottoms of the Mohawl river. Flats of Fish ereek.

Frequent. June.

CRISTATA, Schweinitz.

Plworze-headed Carex.

Low grounds.

Abundant. June.

LAGOPODIOIDES, Schkuhr.

Marshes, shady wet woods.

tenera, Dewey.

Swamps.

FESTUCACEA, Schkuhr.

Meadows, copses.

SCOPARIA, Schleuhr.

Roadsides, bogs.

SYCHNOCEPHALA, Carey.
Hare'sfoot, Lagopus-like Carex.

Frequent. June, July.

Pliant Carex. Common. June.

Festuca-like Carex. Uncommon. July.

Broom-like Carex.

Common. July.

Clustered-headed Carex.

Spicis androgynis inferne mascalis crebris arcte capitato-aggregatis foliosobracteatis; stigmatibus 2; perigyniis compressis e basi ovato-lanceolata abrupte contracta subsessili longe sensimque rostratis apice bifidis margine scabris squamam hyalinam lanceolatam abrupte mucronatam paulo superantibus.

Hab. In Nov. Ebor. Comitat. "Jefferson," ubi legerunt cl. I.B.Crawe, M.D., et cl.W.A.Wood, M.D.

Culm about a foot high, leafy, smooth; spikes sessile, densely clustered, forming a compound capitate spike subtended by 3 long unequal foliaceous bracts much exceeding the spike. Perigynium tapering from an abruptly contracted ovate base into a long and slender scabrous bifid beak, a little exceeding the lanceolate abruptly mucronate scale. Achenium ovate, compressed, crowned with the lengthened style.

This plant, which has a great resemblance to $C$. cyperoides, Linn eds, differs from that species in the nearly sessile perigynium, which tapers from a much wider and contracted (not attenuated) base into a shorter beak, of which the teeth are also shorter than in the European plant. The perigynia are more crowded on the rachis than in $\boldsymbol{C}$. cyperoides, the spikes of which, owing to the greater length of the beaks, have a more comose appearance than in our plaut. The seale is shorter, abruptly mueronate, and not gradually tapering as in $C$. cyperoides; and the achenium is ovate, not ovate-oblong as in that speeies: CAREY in Sill.Jour.

Moist banks, wet meadows. Borders of woods, road side between Watertown and Adams, where it was discovered by Knieskern and Vasey, about the year 1844. Watertown, received from Crawe, Dewey. Littlefalls, above the village, between the eanal and the river, in a luw meadow, Vusey. Rare. June, July.

LENTICULARIS, Wichx.

Lentil-fruited Carex.

On an island in Lake Sanford, not far from the McIntyre Iron-works, Knieskern. Sancy shores of Fourth lake in the chain of Eight, north Herkimer county : only at the water's edgc, often in shade, where it grows two feet high, but on exposed banks it bears full-sized spikes at the height of four or five inches: abundant there.

Rare. July, August.

Adrea, Nuttall.

Golden-fiuited Carex.

Wet rocks and banks. Ledges within reach of the spray from the upper falls, Trenton falls. West-Canada creek, Gray. Marshy slopes round Cedar lake : hillsides of Hidden lake, Litchfield : south Herkimer county. Low grass-lands along the road between Vanhornsville and Summit lake, Springfield, Otsego county. Banks of Oriskany creek, Knieskern. Scarce. June. 
TORTA, Boott.

Curving-spiked Carex.

Low grounds of streams. Starch-factory creck Oriskany creek. Fish creek.

Abundant in a few localities, Yates county, Sartwell.

Uncommon. May, June.

vulgaris, Fries.

Swamp near Oriskany, Knieskern.

Universal Carex. Rare. June.

STRICTIOR, Devey.

Borders of ponds, swamps

Close-leaved Carex.

stricta, Goodenough.

Bogs.

ANGUSTAtA, Boott. Frequent. May, June.

Upright-leaved Carex. Common. May, June.

Narrow-leaved Carex.

Beaver-meadows and marshes of the north woods, abundant. Cold swamps on the sunth range of hills. Junius, Seneea county, Sartwell. Infrequent. July.

AQUATILIS, Wahl.

Water Carex.

Upland swamps. Around Summit lake, and over the open moss swamp above it, Otsego county. Borders of Mud lake, Warren; on Hidden lake, and the State marsh, Litchfield; south Herkimer county. Junius, Seneca county, Sartwell.

Filiform peduncles of fertile spikes, sometimes a foot in length, occasionally proceed from near the root. Scarce. July.

GYNANDRA, Schueinitz.

Swamps. Rome, abundant west of Fort Bull.

CRINITA, Lamarck.

Stream-sides.

POLYTRICHOIDES, MIUhl.

Cedar and moss swamps.

LEUCOGLOCHIN, Ehrhart.
Double-spiked Carex. Frequent. June.

Fringed-spiked Carex.

Common. June, July. Haircap-moss, Polytrichum-like Carex.

Common. June.

White-arrowheaded Carex.

Sphaguum swamps. Scarce about Wetmore's pond, Frankfort hill. Common on the swale of South-Treston. Near North pond. Abundant in the north woods, in nearly all mossy lowlands. Near Watertown, Gray Gram. \& Cyp. Rare. June, July.

Pedunculata, Muhlenberg.

Shady hillsides and rich ravine bottoms.

Long-peduricled Carex. Abundant. May.

WILLDENOWII, Schkuhr. In honor of WILLDENOW.

Dry banks. Watertown, Jefferson county, Crawe, Gruy Gram. \& Cyp.: Knieskern. Yates county, Sartwell.

Rare. June.

Discovered by STEUDEL.

STEUDELII, Kunth.

Hilly woods. Jefferson county, New-York, Wood. Watertown, Dr. W. A.
Wood, Dewey.

BACKII, Boott.

Dedicated to BACK.

Rocky banks. On an island in Perch lake, Crawe, Dewey. About Watertown, Knicskern. Dexter, Jefferson county, Vasey. Rare. June.

SQUARROSA, $L$.

Squarrose-spiked Carex.

Bogs. Near Bath, Steuben county, Knieskern: Sartwell.

Scarce. June, July.

VIRESCENS, Muhl.

Green-spiked Carex.

Shady hillsides, moist woods. Frankfort hill. Cascade glen, southeast of Utica; abundant about the upper falls. Oriskany, Knieskern. Woodlands along the cliffs of Fish creek. Monroe county, L. Holzer.

Frequent. June, July. 
Hirsuta, Willdenow.

Hair-sheathed Carex.

Wet meadows. Schenectady, northeast of College buildings; and along the brow of the Rotterdam hills. Littlefalls, flats of the Mohawk above the village, south side of the river. Peun-Yan, Yates county, Sartwell.

Frequent. June.

BUхвAUмrr, Wahlenberg.

Hunorary to BuxBAUM.

Swamps. Junius, Sartwell. Banks of the Genesee river, Greece, Bradley. At the head of the swamp in West-Bergen, Genesee county. Rare. June.

GRACILLIMA, Schueinitz.

Slender Carex.

Meadows, copses, woods.

Common. June, July.

Formosa, Dewey.

Handsome Carex.

Moist banks and woodlands. Site of old Fort Bull, Rome, Vasey. PennYan, Sartwell.

Infrequent. June.

\section{DAVISII, Torrey.}

Dedicated to E. Davis.

Shaded banks. Utica, Gray Gram. \& Cyp. Along the Mohawk banks opposite Whitesboro, under three butternut trees; below, on wooded hillsides bordering a Cephalanthus swamp. Oriskany, Vasey. Frequent. June.

UMBELLATA, Schkuhr.

Umbellate Carex.

Rocks; sandy hills and plains. Over the river and above Utica. Oriskany, Dewey: F. Boolt. Western part of the State, Gray Gram. \& Cyp. Abundant on the dry plains of Rome. Tufts on the sides of Bald rock, north of Third lake, north Herkimer county. Penn-Jan, Sartwell.

Abundant.

\section{var. vicina, Dewey.}

Near-headed Umbellate Carex.

The form with one or two heads of frnit close beneath the sterile spike, is found on the barren ridges bordering the open sphagnum swamps beyond Rome,

Frequently. June.

\section{EMMonsi, Dewey.}

Dedicated to E. Emmons.

Dry banks. Oriskany, Oneida county; Monnt Hope, Rochester; Dewey. Abundant in a few localities, Yates county, Sartwell. Webster, Monroe county. L. Holzer. Infrequent.

var. Elliptica, Boott.

Long-fruited Carex.

Spicis congestis; perigyniis longioribus ( $1 \frac{6}{10}-\frac{8}{10}$ lin. longis, $\frac{6}{10}$ latis) hirsutis squamam subduplo superantibus; achenio elliptico triquetro $\left(\mathbf{I} \frac{1}{10}\right.$ lin. longo, $\frac{1}{2}$ lin. lato), basi styli decidua. Tab. cclxxxvir. New-York, Knieskern.

The var. has a longer body to the perigynium and a longer achenium, and the pubescence is softer and longer, and the proportionate length of the perigynium to the squamæ gives a peculiar aspect to the spike. It has not been noticed by authors: F. Bootт.

Penn-Yan; Rochester; Dewey.

PENNSYLVANICA, Lamarck.

Infrequent. July.

Shady banks and deep thickets. Sides of the Mohawk valley, from Schenectady to Littlefalls. Sandy ridges opposite Whitesboro, north side of the Mohawk. Common on the plains of Rome.

Radical peduncles of fertile spikes, in addition to the usual one below the sterile, appear frequently in specimens from the pine wonds of Schenectady county; and from sand-ridges among the sphagnum swales west of Rome, between the Oswego county road and Wood creek.

Abundant. May.

NOV A-ANGLI E, Schweinitz.

New-England Carex.

Mountain streams. From Mount Marcy, N.Y., Dewey. Adirondac river, Essex county, Knieskern, Torrey $F l . N . Y$. Lake Sanford, Knieskern.

Rare. July.

VARIA, Muhl.

Dry rocks and banks, both open and shaded.

Variable-sized Carex.

Common. May. 
VESTITA, Willdenow.

Hair-clothed-fruiled Carex.

Sandy copses. Pine plains of Schenectady, Knieskern : Pearson : Tuckerman: F. Boott.

Rare. Juue.

PEBescens, MUhl.

Pubescent Carex.

Opeu rich woods, river-bottom meadows. Banks of the Mohawk river opposite Whitesboro, on sandy sidehills. Meadows, Oriskany. Knieskern.

Watertown. Jefferson county, Gray Gruzn. \& Cyp.

Oceasionally a specimen occurs having an additional fertile spike on a long slender peducle, nearly radical.

Infirequent. June.

FLAVA, $L$ 。

Yellow Carex.

Low grounds, meadows, swamps, shores; most abmdant in limestone soils.

Littlefalls; M md lake; swamp of Cedarville; between Day's corners and

Cedar lake; around Cedar lake; on Hidden lake and the State marsh,

Litchfield; sonth Herkimer ennnty. Utica, Oriskany, Knieskern. Swamps of Rome, west of Fort Bull. Trenton falls, on the rocks opposite the upper falls, in the spray; a small form. Abundant between Stenben station and Boonville; and common along the wet banks of North pond.

Frequent. June - August.

OEDERI, Ehrhart.

Oederian Carex.

Wet banks. Shore of Lake Ontario near Sackett's-harbor, Crawe, Gray Gram. \& Cyp. Watertown, Jefferson county, Vasey. Abundant in the swamp of West-Bergen, Genesee county; a large form. Rare. June, July.

FOLLICULATA, $L$.

Inflated-fruited Carex.

Swamps. Frankfort hill, Fonnd Wetmore's bear-ponul. (Brisliany and Oneida Jake, Knieskern. Western part of the State, Gray in Rare plants of $N$ orthern N.Y.: Gram. \& Cyp. Abundant in the shady swamps of Rome, from old Fort Bull to New-London. Sphagnum swale adjoiniog North pond. Abundant on the borlers of beaver-meadows and sivamps of the north woods.

In marshes occasionally it occurs not over a span high, with two or three full-sized heads of fruit; and at the same time, within a few feet, on firmer ground, it grows to the height of four feet or more. Freguent. Iune, July.

ROSTRATA, Michaux.

Rostrate-fruited Carex.

Shores and elevated marshes. Overflowed sandy point on the soath side of Fourth lake in the chair of Eight; abundant on the level marshes surrounding two ponds, at each end of Bald rock; north Herkimer county.

In bogs, dwarf forms are found, five or six inches high, with two or three perfect beads of fruit.

Rare. June - August.

INTUMEsCENS, Rudge.

Wet meadows and swamps.

Swollen-fruited Carex.

Common. June, July.

GRAYII, Carey.

Discovered by Grax.

Spica mascula solitaria pedunculata; spicis fœmincis 2 globosis densi( 25 - 30-) floris exserte pedunculatis; stigmatibus 3 ; perigyniis deflexopatentibus ovatis ventricosis multi-nervosis rostratis ore bifidis squamam ovatam hyalinam mucronatam triplo superantibus.

$\boldsymbol{H} a b$. Ad ripas fluminum "Mohawk" et "Wood creek," Nov. Ebor. occident. detexit cl. A. Gray, M.D.

Culm 3 feet high, robust, triquetrous, smooth and leafy. Leaves taller than the culm, 4-5 lines broad, rough on the margin. Sterile spike $1 \frac{1}{2}-2$ inches long: fertile spikes globular, occasionally single, but generally 2 , quite distinct and separate, $1 \frac{1}{2}$ inch in diameter. Perigynia crowded, deflexed, smooth and shining, 9 lines in length, 25-30-nerved, tapering into a long perfectly glabrous beak. Achenium obtusely triangular, minutely dotted under a lens, crowned with the long continuous style.

Dr. Gray, who first detected this plant on the banks of the Mohawk at Utica, and described it as a variety of $C$. intumescons, RUDGE, remarks that 
it " is characterized br its larger and coarser habit, and br its globose manrflowered pistillate spikes. It fiowers a month later than the ordinary form of the species, and when young might readily be mistaken for $C$. lupulina." To this may be added, that $C$. intumescens, owing to the scarcely exserted peduncles, has the loose few- (5-8-) flowered spikes closely approximate, so as to be almost indistinguishable; and the perigynia are erect, nuch shorter ( $6-7$ lines long). slightly serrulate towards the apex of the beak, and only 15-20-nerved. Though closely resembling $C$. intunescens, these constant characters, and a marked difference in aspect, appear to entitle this plant to rank as a species : CAREY in Sill. Jour.

This species was found by Dr. GraY in meadows at Ctica, and described, in 1834 , in the Ann. Lrc. N. Tork, as a tariety of $C$. intumescens. The large globulat lemale spikes, the smovth perigrnium with its glatual acmmination iuto a short rostrum, its more copious nerves, stouter and smoother culm and broader leaves, sufficiently distinguish it : F. Bэотт.

Rich river-bottoms. On the flats of the Mohawk below Etica. in meadows, Gray. Above Ltica and opposite Whitesboro. Oriskany, Knieskern: Vasey. Wood creek, J. Carcy. Reappears in the ralley of the Genesee river.

Frequent. July, August.

LtPcuiva, Muhlenberg.

Hop-fruited Carex.

Bogs on the flats of streams, borders of swamps. Common. July, August.

LUPTLIFOR MIS, Sartuell.

Hop-formed Carex.

Cold marshes. Highlands of New-Fork: Barratt, Gray Gram.\& Cyp. Tates county, Sartwell.

Uncommon. July.

TENTACULATA, Muhl.

Marshy places.

Var. PARVULA.

Tentacle-finited Carex.

Common.

form occurs on wet flats of the Mohawh from Littlefalls to Rome, whic is much smaller and more slender than the common plant, with spikes and perigynia less than half the usual size. and of a red-brown color. The scales also are oblong-lanceolate, and nearly entire or eren at the end.

rar. Rostrata, Sartwell. Large-bealed Tentacle-fruited Carex. Water-sides. Penn-Yan, Yates county, Sartwell. June, July.

PLANTAGINEA, Lamarcl.

Ravine-sides and cedar swamps.

CAREYANa, Dewey.

Dry woods. Jefferson county, $W . A$. Wood. Fonnd near Anbnrn in 1832 by JoHy CAREY. Woods near the Genesee river, four or five miles above Rochester, W. Boott: Dewey. Copses in Henrietta, Genesee county.

Rare. May.

LAXIFLORA, Lamarck.

Yoist roods.

Loose-flowering Carex.

Common.

var. intermedi, Boott. Intermediate Loose-flowering Carex. Open woods. Oriskany, Vasey, $F$. Boott. About $\mathrm{Ctica}$, in all ravines, riverbottoms, copses. Yates county, Sartwell.

Abundant. May, June.

var. PAtclfolia, Dewey. Wide-leaved Luose-flowering Carex. Deep rich woods.

Frequent.

\section{PLATYPhylia, Carey.}

Flat-leaved Carex.

Limestone rocks and hillsides. Littlefalls, shadr cliffs of Fall hill, south of the Mohavk. Litchfield, springy sloping meadows between Cedar lake and Hidden lake. Among loose rocks of the Chittenango creek rarine. Wooded sides of the Black river between Brownville and Dexter. Infrequent. June.

BLANDA, Dewey.

Dry woods and meadows.
Delicate-formed Carex.

Common. June. 
RETROCURVA, Dew?y.

Drooping-fruited C'arex.

Copses. Pleasant valley of Oriskany creek, above the dam, Vasey. PennYan, Yates county, Sartwell.

Rarc. June.

CONOIDEA, Schkuhr.

Conical-fruited Carex.

Wet meadows. Schenectady, a mile or more northeast of the Colleges. Western part of the State, Gray Gram. \& Cyp. Frequent in Tates county, sartwell.

GRISEA, Wahlenberg.

Moist woods, thickets, banks.

Scarce. June.

DigitALis, Willdenow.

Gray-fruited Carex.

Common. June.

Shaded hillsides. Watertown, Jefferson county, Crawe, Gray Gram. \& Cyp. The true form from Jefferson connty, Dewey. Dexter. Vasey. Yates county, Sartwell. Frequent about Rochester, C.M. Booth. Wet meadows, Greece, Monroe county, L. Holzer.

Uncommon. June.

EBURNEA, Boott.

Ieory-scaled Carex.

Cliffs. Helderberg mountains, Pearson. Abundant at Littlefalls, south side of the river. Trenton falls. Fish creek precipices, on Hudson river sandstones. Western part of the State, Gray Gram. \& Cyp. Watertown, N.Y., Crawe, Schwein. \& Torrey Carices. All along Crooked lake outlet, Sartwell.

Wet woods. Shady borders of the swamp in West-Bergen, Genesee county; in similar stations as thuse of $C$. gynocrates aud $C$. disperma.

Scarce. June, July.

Grandlaris, Muhlenberg.

Wet meadows, along streams.

var. RECTA, Dewey. Siraight-beaked Granular-spiked Carex. Sterile meadows at Schenectady, mile or more northeast of Union College: abundant there.

On the tops and sides of the Rotterdam hills nccurs a form having short wide root-leaves, broad foliaceous bracts, a single staminate spike sessile at the base of and shorter than the highest fertile one, fertile spikes three or four nearly sessile, perigynia long-ovoid and beakless. Rare. June.

VAGINATA, Tausch.

Sheathed-culmed Carex.

Spica mascula solitaria, pedunculata, oblonga, sub anthesi infracta, femineis subbinis, ternisve, exserte pedunculatis, remotis, erectis, oblongis, laxifloris; bracteis foliaceis, vagina dilatata patula; stigmatibus tribus; utriculis squama apice carinata longioribus, oviformi-triangularibus, basi attenuatis, glabris, rostro brevi, inæqualiter bidentato ; culmo lævi, striato, basi foliato; foliis margine sursum scabris; caudice stolonifero: KUNZE Suppl. zu Schkuhr Riedgr.

Plants growing in large patches, from creeping roots. Stolons three to ten inches in length; invested with sheaths about as long as the nodes. Leaves radical; very long, twelve to eighteen inches; very narrow, only a line and a half wide; glabrous, but rough on the margin from base to end; acuminate; light green. Culms one to two and a half feet in length, usually about twenty inches; with one to three sheaths at base prolonged into short leaves; compressed, flat; striate; smooth or harsh above on the ridges; filiform, weak, leaning from the root with its spikes bending over nearly to the ground, or the whole stem reclining on the leaves; sheathed toward the end. Sheaths from knots of the culm, cylindrical for about an inch, then open and ending as short narrow sharp bracts ciliate or scabrous margined; enclosing the peduncles of the fertile spikes and sometimes the fruit itself. Peduncles a little longer than the sheaths, rarely four inches long if rising from near the root, slender, erect or when elongated drooping with the fruit. Fertile spikes usually two, often only 
one, rarely three; remote, three to five inches; cylindric; about an inch long, loose-flowered, often much longer with scattered alternate fruit on a zigzag rachis. Perigynia rarely globose, with a short beak contracted from its base ; commonly trigonal, narrowed below, bearing a distinct rostrum nearly a line in length, which is turned obliquely outward to a greater or less degree; or frequently long-oval tapering upward, two lines in length, bending with the short beak slightly to one side; nerved; quite smooth. Rostrum rarely bidentate, and hairy at the orifice or down the inside; usually entire and obliquely truncated. Achenium short, triquetrous, with sharp angles; tristigmatic ; stigmas long, exserted one or two lines beyond the beak. Scales ovate, acute, shorter than the perigynia; with green keels and red margins. Staminate spike single, distant two to four inches from the highest pistillate one; long-elliptical ; with lanceolate, nearly obtuse, brown scales; frequently having its peduncle bent at the base, or sometimes refracted even to a right angle.

Shady humid banks around the swamp in West-Bergen, Genesee county; shitely within the circle of arbor vitæ, but among other low evergreens in half-open places and rivulet-sides on the southern border, sometimes in company with $C$. gynocrates.

This species has been found before in Northern America only at Rivière du Loup on the St.Lawrence recently by $W$. Boott, at Montreal formerly by W. F. Macrue, and in the Saskatchawan district long ago. In Europe it is an alpine plant, ranging from the Swiss Alps to Lapland and Iceland.

Local. June,

\section{LIVIDA, Wahlenberg.}

Livid Carex.

Cold marshes. Formerly in the Oriskany swamp, Knieskern: Gray: Vasey. Litchfield, south Herkimer county, nearly a mile southwest of Jerusalem hill, in the center of a deep swamp among the East dry-lots. one of the sources of the Unadilla river. The open lowest part is a marly bog, covered in many places or scattered over all, with this most rare and interesting species.

Local.

var. RADICALIS.

Radical-ferite-spiked Livid Carex.

With the trpical form, on the State marsh. Litchfield. Spikes two, one staminate and one pistillate, on separate peduncles, both springing together fron the root; that of the fertile spike nearly as long as the culm of the sterile, erect.

Specimens of this variety are very scarce, perhaps two or three occurring in a hundred of the regular species. The same variation has been observed by Dr. Knieskern in the swamps about Manchester, N.J. June, July.

TETANICA, Schlcuhr.

Crooked-beaked Carex.

Swampy meadows. To be looked for on the upland marshes among the hilltops of south Herkimer county. Junius, Seneca county, Sartwell.

Rare. June.

WoodII, Dewey.

Discovered by W. A. WOOD.

River-banks. shores. On an island in Perch lake, Wood: Crawe: Dewey. Dexter, Jefferson county, Vasey. Rare. June.

OLIGOCARPA, Schkuhr.

Few-fruited Carex.

Dry copses Borders of sandy plains, Rome, Knieskern. Banks of Wood creek between New-London and Oneida lake, Gray: Gram. \& Cyp. PennYan, Yates county, Sartwell in herb. Ham. Coll.

Rare. June.

\section{HitchсоскIANA, Dewey. Dedicated to Edward Hitchсоск.}

Open woods. Watertown, Jefferson county, Crawe, Gray in Rare plants of Northern N.Y.: Grain. \& Cyp. Auburn, Caruga county, J. Carey. PennTan, Yates county, Sartwell. Sandy grore-lands on the Ridge road near Irondequoit bay, IIonroe county, L. Holzer. Abundant south of Rochester, Dewey.

Infrequent. June, 
DEBILIS, Mich $x$.

Weak-stemmed Carex.

1) amp woods, hills and hillsides. Abundant thruughout the valley of the Mohaik. On Frankfort hill near Wetmore's pond. Site of old Fort Bull on Wood creek, Rome, Vasey. Borders of streams near Oneida lake, Knieskern. Common in the north woods, Lewis and north Herkimer counties.

A small form on the sides of Bald rock.

Frequent.

var. $\beta ;$ Boolt.

Long-scaled Weak-stemmed Carex.

Spicis $5-7$ erectis, terminali mascula vel medio vel basi vel apice et basi mascula, fomineis linearibus angustis flosculis alternatim dispositis, inferioribus sæpe basi compositis; perigyniis brevioribus, rostro rarius scabro, squama oblongo-ovata obtusa vel acuminata acuta mutica ciliata subæquilata longioribus. Hab. New-York, Sartwell.

Between $\alpha$ and $\beta$ there are intermediale forms which insensibly unite them. The specimens figured approach $C$. urctata; but the scales and the sessile perigynium, with its acute base, at once distinguish them : F. Boort.

Rare. Jane.

GLABRA, Boott.

Smooth Carex.

Woods and plains.

Spicis $4-5$ oblongis vel cylindricis pedunculatis pallidis, terminali apice vel basi vel apice et basi rarius omnino mascula, reliquis fœmineis subdensifloris, superioribus approximatis inferioribus longe exserte pedunculatis nutantibus basi attenuatis laxifloris interdum compositis, infima remota; bracteis vaginatis culmum subæquantibus; stigmatibus 3 ; perigyniis triquetris turgidis lanceolato-ellipticis utrinque acutis vel rostellatis glabris, ore bidentato, (laciniis acutis) nervatis nervis prominentibus pellucide punctatis viridibus, squama ferruginea medio viridi nervata scabra ovato-lanceolata acuta vel mucronata rarius obtusa ciliata latioribus subduplo longioribus. ( Tab. ccLxxv.) Hab. In America Sept.; New-York. Knieskern.

Culmus $1 \frac{1}{2}-2 \frac{1}{2}$ pedalis, apice setaceus, scaber; pars spicas gerens 4- 9 poll. longa. Folia $\frac{1}{2}$ lin. lata, supra vaginæque inferiores scabriusculæ. Bracteæ (nisi suprema) vaginatæ, culmum subæquantes, vel infima nunc eo brevior. Vagina infima sub 2 poll. longa, scabriuscula. Pedunculi setacei, scabri, $2-3$ poll. longi. Spicæ $8-21$ lin. longæ, 2 lin. latæ. Squamæ ferrugineæ, medio viridi nervatæ, scabre: masculæ lanceolatæ, obtusæ, muticæ, apice ciliatæ: fœminex acutæ vel obtusæ, mucronatæ. Perigynium $2 \frac{7}{10}-3$ lin. longum, $\frac{8}{10}-\frac{9}{10}$ lin. latum, bidentatum, laciniis acutis (nec membranaceis), nervis usque ad apicem conspicuis. Achenium 1 lin. longum, $\frac{6}{10}$ lin. latum, ovali-triquetrum, stipitatum, basi styli apiculatum, flavidum.

A C. oxylepide differt culmo, foliis pedunculisque glabris (nec pilosis); perigyniis majoribus; squamis mucronatis; spicis inferioribus nutantibus, compositis.

A C. formosa differt spicis inferioribus, omnino fœmineis, etc.

A $\boldsymbol{C}$. debili differt perigyniis rostellatis, ore acuta bidentato nec hyalino, magis turgidis; nervis validioribus; squamis firmioribus.

I have received this speries under the names of $C$. formosa and $C$. debilis. The absence of the subelongate rostrum, and of the hyaline obtuse orifice, separates it from $C$. debilis and its allies. It has hitherto escaped the notice of American botanists, and its value as a species must be determined by future observation: F. Bоотт.

Spicis distinctis cylindraceis pedunculatis; terminali staminifera, interdum ad apicem vel basin pistillifera, vel in medio; spicis pistilliferis, 3-4, sublaxifloris, bracteatis, inferne longo-pedunculatis et nutantibus; fructibus tristigmaticis ovalibus subinflatis et inferne teretibus, superne conicis brevirostratis, bidentatis glabris nervosis, squamam oblongam subacutam vel lanceolatam multo superantibus; planta pallida et glabra. 
Culm $1 \frac{1}{2}$ foot high, slender, erect, leafy toward the root; staminate spike slender, sometimes with a few fruit at the apex, in the middle or at the base; pistillate spikes $3-4$, cylindric, slender, rather loose-flowered, on slender peduncles with sheathing bracts which equal the culm nearly; stigmas 3 ; fruit oval, tapering below and conic above, smooth and glabrous, nearly twice longer than the oblong acutish scale which is white on the margin and green on the back : whole plant light green.

This plant is the well-known glabrous form of $C$. Alexuosa, Schkurr, the C. debilis, Mrснaux, and blended with it, till Dr. Bootт separated them in 1860 : DEWEY in Sill. Jour.

The glabrous form of the old C. fiexuosd; this was extended to C.debilis, Michaux, and then was remote from $C$. glabra, Bootr : received from Rome or Oriskany, Dewey.

Local. June.

ARCTATA, Boott.

Contracted-beaked Carex.

Shady banks. Littlefalis, south side of the river below the town. Ravinebottoms and ridges, throughout the flats, and among the headwaters of Starch-factory creek. Frankfort hill, copses and groves near bear-pond; abundant on Jerusalem hill, bordering the cedar swamp of the State marsh; wooded sides of Hidden and Cedar lakes; south Herkimer county. Banks of Oriskany creek opposite the Dexter factories. Woodlands between Oriskany and Rome. Beyond Rome, cleared land west of Fort Bull, with C. flexilis. Valley of Fish creek north of Taberg, above the cliffs. Occasional in the north woods.

Infrequent. May, June.

KNIESKERNI, Dewey.

Discovered by KNIESKERN.

Copses. Rome and Oriskany, from Knieskern, Dewey. In a shady field near Fort Bull, Vasey.

Local. June.

\section{FLEXILIS, Rudge.}

Flexile Carex.

Low borders of woods. Litchfield, southwestern Herkimer county, Cedar lake, on the moist sloping banks seattered with young evergreens; where it was first observed in the United States, and received from the discoverer a far better name, C. blepharophora, GraY in Rare plants of Northern N.Y. Old Fort Bull on Wood creek, Knieskern: Vasey. Abundant still in the clearings and swamps west of the fort and south of the Erie canal.

Rare. May, and early in June.

RICHARDSONI, $R$. Brown.

Dedicated to RICHARDSON.

Dry woods, Parma, Monroe county, north side of the ridge, Bradley. Discovered in this locality long before the expedition to British America, Dewey. Rare. July.

TORREYI, Tuckerman.

Honorary to ToRREY.

Spica mascula solitaria, fem. $2-3$ incluse pedunculatis erectis, stigmatibus 3 , fructibus subglobosis obovatis obtusis nervosis glabris rostello brevi integro mucronatis, squama acuta mucronata duplo longioribus, caule foliis bracteis squamisque ad carinam pubescentibus. Haв. Nov. Ebor., Torr.! in herb. Hook. (sub C. pallescente). Pedalis et sesquipedalis, omnino nisi fructus pubescens : Tuckerman Enum. Car.

Utica, Gray. Received from the central part of the State, Dewey.

Local. June, July.

\section{CRAWEI, Dewey.}

\section{Discovered by CRAwE.}

Limestone rocks and banks. Guffin's bay in Black river near Watertown, Crawe, Dewey. At the mouth of Black river, Sackett's-harbor, Vasey. Cedar lake, Litchfield, south Herkimer county, south side, on moist marly slopes under young arbor vitæ. Barren spots of marl in the swamps of West-Bergen, Genesee county.

Rare. June, July.

SCABRATA, Schweinitz.

Rough Carex.

Swamps, streams, cold bogs in meadows and woods. Common. Junne, Juy.

[ON. PL.] 
PALLESCENS, $L$.

Wet rocks and meadows. Common on the flats of the Mohawk. Trenton falls, on rocks wet by the spray from the upper falls. Clitls of Fish creek above Taberg.

Frequent. June.

LIMOSA, $L$.

Bog Carex.

Moss marshes. Iitchfield, south Herkimer county, abundant on IIidten lake and the State marsh of Jerusalem hill; sphagnum borders of Wetmore's pond, Frankfort hill. North pond, southwest of Boonville. Common in the lake-marshes and mossy lowlands of the Northern wilderness. Frequent.

\section{var. RADICALIS.}

Radical-fertile-spiked Bog Carex.

Level bogs, round Wetmore's sphagnum pond on Frankfort hill, south Herkimer county.

An extremely rare state having two spikes only, the sterile at the top of the naked erect stout culm, the fertile drooping at the end of a filiform radical peduncle four to nine inches long.

This is considered a variety, because the peduncles of both sterile and fertile spikes rise together from the root. Many other species bear fertile spikes on long peduncles nearly radical, in addition to their usual number on short peduncles just beneath the staminate; but these are regarded as intermediate forms merely. June, July.

MAGELLANICA, Lamarck.

From the Strait of Magellan.

Hab. In Europa et America septentrionali et australi. Lapland to Switzerland. Arctic America to Penn. I have adopted the name of LAMArck, as I cannot see any specific distinction between the Fuegian and the European and American plant; but I have described the last as the typical form : F. Bоoтt. C. irrigua, W АнL. Норр. Sмiтн.

Cold swamps. Arbor-vitæ and tamarack borders of Mud lake; abundant on the high marshes of Jordanville; suuth Herkimer county. Sill liugering about the station where it used to flourish in the days of the old Oriskany swamp; over the south hill, in a sphagnum bog. Common in the Paris-hill marsh. Throughout the swamps and swales of Rome. About Point of Rock lake, and in all the moss-bogs of the northern part of the county.

In the mossy lowlands of the north woods a tall form abounds, fewflowered and slender-fruited.

In the swamp beyond Fort Bull, Rome, the form having additional spikes on long peduncles, nearly radical, occurs frequently. Rare. June.

MILIACEA, Muhlenberg.

Millet Carex.

Borders of streams, river-bottom meadows.

Common. June.

HYSTRICINA, Willd.

Ditches, water-sides.

Porcupine-fruited Carex. Common... July.

PSEUDO-CYPERUS, $L$.

Cyperus-like Carex.

Marshes, water-courses. North of Summit lake, Otsego county. Shady mossy borders of Mud lake; abundant on the tamarack swamps of Jordanville; sparingly at the head of Ilidden lake, Litchfield; south Herkimer county. Oriskany, raceway between the factories, Knieskern. In all the cold bogs east of Fish creek, around Point of Rock lake, and through the northern part of the county. Penn-Yan, Yates county, Sartwell.

Scarce. July, August.

COMOSA, Boott.

Bristly-spiked Carex.

Bogs in meadows, woods, swamps, and stream-sides.

Common. July, August.

TRICHOCARPA, Muhl.

Hairy-fruiled Carex.

Banks of creeks, rivulets, low-lands.

Abundant.

var. $\beta$, Boott.

Smooth-fruited Carex.

Perigyniis glabris, rostro ad margines laciniisque scabris; vaginis scabris. Penn-Yan, Sartwell; F. Bоотт.

June, July. 
LANuginosa, Michx.

Woolly-fruited Carex.

Thet meadows. Littlefalls, flats of the Mohawk, south side of the river above the town. Dexter, Jefferson county, Vasey. Western part of the State, Gray Gram. \& Cyp. Yates county, Sartwell.

Infrequent. June.

FILIFORMIS, $L$.

Filiform-leaved Carex.

Cold marshes, banks, shores. Summit lake, northern Otsego county. About Mud lake; on the tamarack swamps between Page's corners and Jordanville, TTarren; around Cedar lake; conimon on Hidden lake; State swamp near Jerusalem hill, Litchfield; south Herkimer county. Swamps just over the ridge along the head of Oneida lake. Bogs and lake-shores of the north woods.

Frequent. June, July.

STRtatA, Michx.

Nerved-striate Carex.

Swamps and low grounds. Testern counties, Torrey Fl. N.Y. Year Oriskany, Vasey. On an island in Lake Sanford, Essex county, Knieskern.

Rare. June.

RETRORSA, Schweinitz.

Recurved-fruited c'arex.

Wet meadows, marshes. Around the lakes, and in all the cold swamps on the hills southward. Throughout the flats of the Mohawk.

Frequent. June, July.

\section{SCHWEINITZII, Dewey.}

Complimentary to ScHweInitz.

Low rivulet-sides, flats of streams, cedar swamps. Sparingle at Oriskany, in marshy grounds along the railroad; and between Oriskiny creek and the raceway. Bridgewater, and swamps in the southern part of the county, Gray. Common in the limestone region, from bejond Frankfort hill to Cedar lake, in all rivulet-banks, meadows, ravine-bottoms, swamps; also in the great swamp at Cedarville; south Herkimer county.

Rare. June.

mirata, Dewey.

Admirable Carex.

Cold marshes. Discovered in June 1829, in Greece, Monroe county, on the lanks of a small stream, by Dr. S. B. BRADLEY. The station was destroyed soon after; and the plant has not been rediscorered by most diligent search up the stream and down its length to the Lake, or by thorough exploration of the whole region.

Local. June.

LONGIROSTRIS, Torrey.

Long-beaked Carex.

Dry banks. Littlefalls, two miles below the town, among the shaded rocks near the end of the north cliff. Fish creek, Rome, abore the crossing of the Oswego county road, in thickets along the banks. Below the bridge, Vasey. Vienna, Knieskern.

Scarce. Early in June.

VASEYI, Dewey.

Honorary to VASEY.

Wet banks.

I find in Tuckerman's herb. specimens associated with $C$. monile from Penn-Yan (the C. monile No. 152 of SARTwell's Collection), which do not agree with the original description of $C$. monile, or with the Ohio specimens from which that description was made. They approach in aspect C. vesicaria; but differ from it, and from $C$. monile, in having a long cylindric serrated rostrum, an oblong-ovate perigynium, with elongated sharp rough laciniz: F. Bootr.

These specimens were $C$. vaseyi, as are all gathered at Penn-Yan by Sartwell, DEWEY.

Rare. July.

\section{HARTII, Dewey.}

Discovered by S. HART WRIGHT.

Spikes extremely variable : the sterile sometimes wanting, usually single, often two or three, frequently with fruit scattered along its sides or with a cluster of perigynia at its base, rarely both, the highest one longest and all slender-cylindric, with linear scales : the fertile, short cylindric, two to seven in number, commonly four; the upper one or two sessile with long leafy bracts, sometimes interrupted by staminate flowers or wholly 
sterile at the end, closely fruited; middle ones oblong, short-pedunculate, often two or more springing from the same sheathing bract; the lowest on very long peduncles five to ten inches in length, rising from leaves near the root, recurved, loose-flowered particularly at base, staminiferous at summit socasmally. Sciemas thece. Perigsna ovid or conical, tapering inte) a long heak cnding $m$ diverging teeth, all spreading or somewhat retrorse, three or four times longer than the small lanceolate scale. Culm one to three feet high, erect, smooth nearly to the top. Bracts, sheaths long and narrow; the lower stem leaves extremely prolonged, sometimes twice the length of the culm; all only two or three lines wide, very scabrous on margin, and deeply striate with noded nerves.

Low grounds. Dundee, Yates county, S. $H$. Wright; Ludlowville, Tompkins county, H.B.Lord; along Seneca lake, Dewey. Abuudant in the southwestern part of the State.

var. Bradeley , Dewey. Discovered by S. B. Bradlex. Smaller, the whole plant more slender and graceful. Staminate spikes simple, the stamens less scattered on fertile spikes. Perigynia shorter and narrower, with comparatively larger scales.

Along streams. Greece, Monroe county, Bradley. Found in searching for C. mirata. Near Penn-Yan, Yates county, Sartwell. Rare. July.

RIPARIA, Goodenough.

Lake-shore Carex.

Marshes along streams, lakes. Abundant on the flats of the Mohawk, throughout its length; and occasionally ascending its creeks and headstreams, Near Oneida lake, Knieskern. Frequent. May, June.

ARIstatA, $R$. Brown.

Bearded-leaved Carex.

River-banks Watertown, Jefferson county, Crawe, Gray in Rare plants of Northern N.Y.: Torrey Cyp. Brook-side between Watertown and Adams, Jefferson county, Vasey.

Local. June.

UTRICULATA, Boott.

Leathern-bottle-fruited Carex.

Banks and shores.

Abundant.

var. SPARSIFlora, Dewey.

Loose-flowering Carex.

Watertown, Jefferson county, Crawe, Dewey.

Local.

var. MINoR, Sartwell. S'maller Leathern-bottle-fruited Carex.

Omnibus partibus minoribus, F. Bоотт.

Penn-Yan, Yates county, Sartwell; Ludlowville, Tompkins county, $H$. B .

Lord. Sent from Jefferson county by Crawe, Dewey. Rare. June-August.

Ampullacea, Good.

Flask-fruited Carex.

Level marshy borders of an elevated pond at the east end of Bald rock, north of Third lake, north Herkimer coanty. Borders of Cedar lake, south Herkimer county.

Rare. July.

MONILE, Tuckerman.

Necklace-fruiting Carex.

Bogs and water-sides. Southern Lewis county, and about a mile sonth of Boonville, near the canal, around pools, Knieskern. Rare. June, July.

TUCKERMANI, Boott.

Low meadows, shady stream-sides.

VESICARIA, $L$.
Discovered by TuCKERMAN. Common. July.

Bladder-fruited Carex.

Swamps of the north woods near Third lake, Herkimer county.

Rare. July, Augest.

BULlata, Schkwhr.

Bubble-fruited Carex.

Meadows, on the flats of the Ifohawk river; at Littlefalls. and westward. Occasionally in uplaud marshes.
Scarce. June. 
PHYSEMA, Devey.

Inflated-fruited Carex.

Swamps. Utica, Rome, Knieskern. New-London and Bridgewater, Gray. Penn-Yan, Yates county, Sartwell.

Infrequent. June.

oligosperma, Michaux.

Few-seeded Carex.

Cold marshes. Oneida lake, Knieskern. Bogs in the sphagnum swales six miles west of Rome. South-Trenton, in abundance. Common in the beaver meadows, swamps, and pond-borders of north Herkimer and Hamilton counties.

Rare. June - August.

GRAMIXE.Z.

Grasses.

LEERSIA, Solander.

ORYZOIDES, Swartz.

Cut-grass. White Grass.

Rice-like Leersia.

Water-sides, low sandy shores.

vIRGINICA, Willdenow.

Common. August, September.

Marshes, moist woods.

Virginian Leersia. Infrequent. August.

ZIZANIA, Gronovius.

Indian Rice. AQUATICA, $L$.

Water Zizania.

- Rirer and Jake marshes. Lowlands of the Mohawk. Borders of Oneida lake, Knieskern. Abundant round Onondaga lake. Oswego river, Eaton bot. Common in all the bays, inlets, marshes on the shore of Lake Ontario, from several miles northeast of Oswrego, through Sodus bay and the mouth of Genesee river, to Braddock's bay, Monroe county.

Frequent. August, September.

ALOPECURUS, $L$.

Foxtail Grass.

GENICULATUS, L.

Floating, Jointed Alopecurus.

Wet meadows. Between Albany and Kenwood, G. H. Peck. Oriskany creek, in pools above the factories Pleasant-valley, Vasey. Penn-Yan, Yates county, Sartwell.

Rare. July.

\section{ARIstulatus, Michaux.}

Short-bearded Alopecurus.

Flats of streams. Littlefalls, below the town. Borders of Canaderaga lake outlet, Otsego county. Along Wood creek near Fort Bull, Rome, Knieskern. Common in the valley of the Unadilia, Gray; western part of the State, Gram.\& Cyp. Shore of Lake Ontario on Sodus point, Wayne county. PennYan, Yates county, Sartwell.

Infrequent. June.

PHLEUM, $L$.

PR.ATENSE, L.

Waysides, borders of fields, grass lands.

VILFA, Adanson.

VAGINAFLORA, Torrey.

Barren banks. Watertown. Jefferson county, Gray in Rare plants of Northern N.York. Abundant along the sandy shore of Sodus bay inside the point, Wayne county. Penn-Yan, Yates county, Sartwell. Rare. September.

SPOROBOLUS, R. Brown.

Drop-seed Grass.

HETEROLEPIs, Gray.

Dry soil of cliffs.

Foliis setaceis; panicula prramidata, sparsiflora; gluma inferiore subuliformi, superiore ovata, cuspidata, subduplo breviori; valvulis periantho subæqualibus, muticis, gluma extima paulo minori.

Root perennial. Culm $1-2$ feet in height, smooth. Leaves convolute- 
setaceous, with the margins hispidly scabrous upward; the lower ones equalling the culm; the upper ones much shorter. Lower sheaths pilose; upper ones smonth. Panicle pyramidal, spreading or subcontracted; branches solitary, nearly simple, few and loosely flowered. Glumes purflish; the outer one reduced to a subula, about one-half the length of the inner one, which is strikingly membranaceous in texture, ovate or ovate-oblong, one-nerved, with the nerve produced into a short cusp. $V$ alves of the perianth oblong-lanceolate, rather obtuse, thin and membranaceous, a little shorter than the superior glume. Inferior valve obscurely one-nerved, slightly apiculate. Superior valve two-nerved, a little shorter than the outer one. Stamens 3. Anthers large, linear, orange-red. Stigmas 2, hairy. Styles very short. Caryopsis subglobose, coriaceous, smooth and shining.

Ha B. On rocks, Watertown, Jefferson county, Dr. Crawe: Gray in Rare plants of Northern N.Y.

Rare. August, September.

\section{CRYPTANDRUS, Gray.}

Hidden-flowered Sporobolus.

Panicle pyramidal, the base usually inclosed in the upper sheath, with spreading mostly alternate branches, which are hairy in the axils; spikelets racemose; flowers awnless; lower glume very short; the upper one as long as the nearly equal lanceolate acute palex; sheaths bearded at the throat: Turrey Ann. Lyc. N.Y.Fl. N.Y.

Sandy wastes. Shores of Onondaga lake, along the west side. Abundant on the beaches of Lake Ontario, from Sodus point, Wayne ocunty, to Braddock's bay, Monroe county.

Rare. August - October.

SEROTINUS, Gray.

Late-flowering Sporobolus.

Moist banks. Shady water-sides at the head of Sodus bay. Wayne county. Rare. September.

AGROSTIS, $L$.

PERENNANs, Tuckerman.

Bent-grass.

Damp shady woodlands. Half-open places in all deep arbor-ita swanp. On the flats of the Mohawk, and the hills of the southern part of this connty and south IIerkimer county. Near Bridgewater, Gray. Frequent in the north woods. Penn-Yan, Yates county, Sartwell in herb. Ham. Coll.

Scarce. August.

sCABRA, Willdenow. Hair-grass. Rough-panicled Agrostis.

Old fields, rocky woods, barren hillsides, dried swamps. Common at Littlefalls, and on the south range of hills. Woods of north Herkimer county.

Abundaut.

var. MONTANA, Tuckerman.

Mountain-side Agrostis.

Exposed rocks. Bald rock, north of Third lake, in short tufts or turfs in the hollows of the surface : leaves very short, setaceous. Rare. August.

VULGARIS, Withering.

Common Agrostis.

Meadows, fields, banks. Native near Oneida lake, Gray in herb. Sartuell Ham. Coll. Shore of Lake Ontario, at Sackett's-harbor, Gray. Frequent along the sonth side of the Lake, on sandbanks and ridges.

Everywhere naturalized.

August.

$A L B A, \mathrm{~L}$.

Low grass-lands, swamps.

var. $\mathcal{A R I S T} \mathcal{A T} \mathcal{A}$, Gray.

Sandy fields, near Oneida lake, Knieskern. Sandy field near the outlet of Oneida lake, Torrey $F l . N . Y$.
White-panicled Agrostis. Abundant. July.

Awned Agrostis. Uncommon. June. 
CINNA, $L$.

ARUNDINACEA, $L$.

Reed-like Cinna.

Inundated shady banks of streams, lakes. Along the Mohawk and its head streams. Outlets of lakes in the western parts of the State.

Sometimes in swamps. Abundant in the marshes on the west side of Onondaga lake.

August, September.

var. PENDULA, Gray.

Drooping-flowered Cinna.

Cold damp woods. Frequent in the high woodlands on the hills south of the Mohawk valley, from Summit lake, Otsego county, to Hidden lake, south Herkimer county. Oriskany swamp, formerly, Vasey. Trenton falls, Gray. Alexandria bay, St.Lawrence county, G.W.Clinton. Rare. August.

MUHLENBERGIA, Schreber.

Dropseed-grass. Muhlenbergias. SOBOLIFERA, Gray. Shoot-bearing-rooted Muhlenbergia. Hilly woods. Penu-Yan, Yates county, Sartwell in herb. Ham. Coll.

Scarce. August, September.

GLOMERATA, Trinius.

Clustered-spiked Muhlenbergia.

Swamps. Abundant in all the upland marshes from Summit lake, Otsego county, to Hidden lake, Litchfield, south Herkimer county. Bridgewater region, Gray. Sandy plains, Oneida county, Knieskern. Frequent. August.

MEXICANA, Trinius.

Low banks of streams, meadows, fields, hedges.

sylVATICA, Torrey \& Gray.

Borders of woods, open swamps.

WILLDENOVII, Trinius.

Rocks and hillsides. Shady banks below the cliffs at Bignose point on the Mohawk, Montgomery county. Along the stony sides of cliffs and brows of precipices at Littlefalls, Herkimer county. Sheldrake point, Cayuga lake, Gray. Yates county, Sartwell.

DIFFUSA, Schreber.

Dropseed. Spreading Muhlenbergia.

Dry woods and fields. Sandy plains between Albany and Schenectady. Open rocky steeps at Spraker's, Montgomery county. Dry eliffs of Fish creek. Yates county, Sartwell.

Infrequent. August, September.

\section{BRACHYELYTRUM, Beauvois.}

ARISTATUM, Beauv.

Ravine-sides, rocky woods and hills

CALAMAGROSTIS, Adanson.

CANADENSIs, Beauvois.

Awned Brachyelytrum.

Frequent. June, July.

Marshes. Abundant on the hills south of the Mohawk valley. The grass of the beaver meadows of the north woods.

confinis, Nuttall.

Close-flowered Calamagrostis.

Swamps. In abundance near Penn-Yan, Yates county, Sartwell.

From the lowest sheaths of primary leaves of the usual width arise clusters of remarkablylong filiform involute leaves, two feet in length, reaching nearls to the paricle. Rare. July, August.

ARENARIA, Roth.

Sand-reed Calamagrostis.

Barren beaches. Abundant on the shore of Lake Ontario. over the long bars against Round pond, Long pond, Cranberry pond and Braddock's bay, Monroe county; covering the ridges of clear sand, with Cyperus schweinitzii.

Local, July - Septẹmber 
ORYZOPSIS, Michaux.

Mountain Rice.

MELANOCARPA, Muhlenberg.

Black-fruited Oryzopsis.

Gulf-sides, rocky banks. In copses along the steep sidehills above Bignose point on the Mohawk, and among shaded talus of the cliff's themselves, Montgomery county. Kocky woods at Littlefalls, Herkimer county. Around Oneida lake, Gray. Ravine of Chittenango creek. Frequent. August.

ASPERIFOLiA, Michaux.

Shady sandy sidehills.

canadensis, Torrey.

ARISTIDTA, $L$.

DICHотома, Michaux.

Poverty-grass. Three-awned-grass. Base-branching Aristidia.

Sandy plains, dry hillsides. Barren fields in Rotterdam, Schemetady county, $E . W . P a i g e$. On the pine plains of Rome probably. Infrequent. July.

SPARTINA, Schreber.

CyNOSUROIDES, Willdenow.

Marsh Grass.

Cynosurus-like Spartina.

Lake marshes. Watertown, Jefferson county, on the rocky hanks of Black river; Oneida lake; Gray. Onondaga lake; all round. Cayuga marshes. Canandaigua lake, Sartwell in herb. Ham. Coll. Scarce. August-October.

STRICTA, Roth.

Salt-marsh Grass.

var. Alterniflora, Gray. Alternate-flowering Spartina.

Banks and marshes of Onondaga lake, chiefly along the west side.

Rare. August, September.

ELEUSINE, Gartner.

INDICA, Gært.

Yard-grass.

Around dwellings. Waterloo, Seneca county, Sartuell. July-September.

LEPTOCHLOA, Beauvois.

FASCICUlaris, Gray.

Clustered-flowered Leptochloa.

Abundant at Salina, and on the springy slopes southeastward along the banks of Onondaga lake : short and spreading over wet shores, but erect and tall in grassy marshes.

Rare, August - October.

DACTYLIS, $L$.

GLOMERATA, L.

Fields, in shade.

Clustered-fruited Dactylis.

Frequent. June.

\section{EATONIA, Rafinesque.}

овтUsata, Gray.

Obtuse-glumed Eatonia.

Damp places in woods and fields, Oneida county, Kniestiern. Western part of the State, Gram.\& C'yp.: Seneca lake, Gray. Yates county, Surtwell in herb. Ham. Coll.

A small form is occasional in deep shady swamps. Scarce. June, July.

Pennsyluanica, Gray.

Pennsylvanian Eatonia.

Moist hanks. Burders of marshes on the shore of Lake Ontario.

Occasionally. July - September.

var. MAJOR, Torrey.

Wet woods and borders of swamps.
Greater Pennsylvanian Eatonia.

Frequent. June, July. 
GLYCERIA, R. Brown.

Manna Grass.

CANADENSIS, Trinius.

Canadian Glyceria.

Swamps. Near Oriskany, Knieskern. High bogs of Bridgewater; and Brookfield, Madison county, Gray. Western part of the State. Gram. \& Cyp. Junius, Seneca county, Sartwell in herb. Ham. Coll. Infrequent. July, August.

Elongata, Trinius.

Long-panicled Glyceria.

Borders of woods and swamps. Thronghout the valley of the Mohawk. Common in the southern part of the county, Gray. Western part of the State, Gram.\& Cyp.

Frequent. June, July.

NeRVATA, Trinius.

Wet meadows, rivulet-sides, swamps.

Nerved-flowered Glyceria.

Common. June.

PALLIDA, Trinius.

Pale-flowered Glyceria.

Water-margins, wet banks. Borders of Canaderaga lake outlet, Richfield and Exeter, Otsego county. Wood creek, near New-London, Knieskern. Abundant on the shore of Oneida lake, Torrey Fl. N.Y. Western part of the State of New-York, Gray Gram.\& Cyp. Gorham, Seneca county, Sartwell in herb. Ham. Coll.

Infrequent. July, August.

AQUATICA, Smith.

Low meadows.

FLUITANS, $R$, Brown.

Borders of ponds, streams.

ACUTIFLORA, Torrey. Coll.

POA, $L$.

ANNUA, L.

Fields, waysides.

BREVIFOLIA, Muhlenberg.

Moist rocky places. Western part of the State, Sartwell, Torrey Fl. N.Y. Penn-Yan, Yates county, Sartwell.

ALSODES, Gray.

Rare. April, May.

Woodland Poa.

Shady hillsides. Around Bald rock. north Herkimer county, and abundant on damp shaded banks of springs throughout the north.woods. Utica, Gray Gram. \& Cyp. Bridgewater, Gray. Moist rocky banks of Fish creek, and on wooded talus between the cliffs and the stream. Penn-Yan, Yates county, Sartwell.

Infrequent. June.

DEBILIS, Torrey.

Weak-stemmed Poa.

Rocky banks. Watertown, Jefferson county, Knieskern: Penn-Yan, Yates county, Sartwell, in herb. Ham. Coll.

SEROTINA, Ehrhart.

Wet meadows.

TRIVIALIS, L.

Low grass-lands.

PRATENSIS, L.

Shady fields and flats of ravines.

COMPRESSA, $L$.

Dry banks. Sometimes on elevations in deep cedar swamps.

Late-flowering Poa.

Common. July, August.

Roadside Poa.

Occasionally in abundance. July.

Meadow Poa.

Common. May - July.

Flat-stemmed Poa.

Common. June - August, 


\section{ERAGROSTIS, Beauvois.}

REPTANs, Nees von Esenbeck.

Creeping Eragrostis.

Banks of streans, lakes. Wood and Oneida crecks, Knipskern. Abundant over low sandy shores all along the head of Oneida lake. Cayuga lake, Gruy. Potter, Yates county, Surtuell. Penfield, L. Holzer; Grece. Monroe county, Bradley. Frequent on the beaches of Lake Ontario, from Sodus point, Wayue county, to Braddock's bay, Monroe county. Scarce. July, August.

POAOIDES, Beauvois.

Poa-like Eragrostis.

Sandy or gravelly places, Oriskany, Knieskern. Penn-Yan, Yates county, Sartwell.

Rare. July, August.

var. MEG.AST.ACHYA, Gray.

Large-spiked Eragrostis.

Sandy fields, banks. Ithaca, Ton:pkins county, Gray. Westeru part of the State, Gram.\& Cyp.

Scarce. August, September.

CAPILlaris, Nees.

Capillary-panicled Eragrostis.

Hillsides, dry banks. Western part of the State, Gray Grum. \& Cyp. Sterile fields along Clyde river, Wayne county. Bluff point, Crooked lake, Sartwell.

Frequent. August.

FESTUCA, $L$.

TENELLA, Willdenow.

Fescue-grass.

Slender Festuca.

Barren soils. Penn-Yan, Yates county, Sartwell. Monroe county, C.M. Booth.

Uncommon. July.

OVIN.A, Gray.

Sheep Festuca.

var. DURIUSCULA, Gray.

Hard Festuca.

Dry banks. Dexter, Jefferson county, Vasey. Sandy fields near Irondequoit bay, C.M. Booth.

Rare. June, July.

\section{ELATIOR, L.}

Tall Festuca.

Borders of fields, low river-banks.

Common. June, July.

NUTANS, Willdenow.

Nodding Festuca.

Borders of woods. Abundant at Littlefalls, in shady rocky hillsides. Utica, Gray Gram. \& Cyp. On the hills south of the Mohawk valley. Frequent.

A depauperate form, bearing a slender instead of a branching panicle, occurs in cold cedar swamps. July.

\section{BROMUS, $L$.}

SECALINUS, L.

Rye Bromus.

Cultivated grounds, borders of flelds.

Common. July.

RACEMOSUS, $\mathrm{L}$.

Raceme-panicled Bromus.

Roadsides, between New-Hartford and Paris hill. Uncommon. July.

KALMII, Gray.

KaLM's Bromus.

Banks of the Mohawk and Fish creek, Knieskern. Utica, Gray. Along the Black river at Dexter, Jefferson county, Vasey. Shores of the lake, Seneca county, Gray.

- Infrequent. June, July.

CILIATUS, $L$.

Fringed-flowered Bromus.

Strean-sides, rocky banks. Ravine of Ilion creek. Trenton falls. Sometimes in shady swamps.

Frequent. July, August.

STERILIS, L.

Penn-Yan, Yates county, Sartwell in herb. Ham. Coll.

Barren Bromus.

Rare. July. 
PHRAGMITES, Trinius.

Reed. communis, Trin.

\section{Common Phragmites.}

Swamps, lake marshes. On the pine plains of Schenectady, Pearson. Summit lake, Otsego county. Oriskany. Knieskern. Common throughout the Cayuga marshes. Western part of the State, Gram. \& Cyp.: head of Senea lake, Gray. Foot of Crooked lake, Sartwell. In all bays and marshes along the shore of Lake Ontario. Abundant in the swamp of TestBergen, Genesee county.

Frequent. August, September.

LOLIUM, $L$.

Darnel.

PERENNE, L

Perennial Lolium.

Meadows. pastures. Borders of fields on the flats of the Mohawk. Geneva, Sartwell in herb. Ham. Coll.

Uncommon. June.

TE MULENTUM, L.

Injurious-fruited Lolium.

Among the rocks at Littlefalls, Herkimer county. Infrequent. July.

TRITICUM, $L$.

Wheat-grass.

VULGARE, Villars.

Common Wheat.

Banks of the Mohawk. Embankments of the Central railroad.

Escapes frequently. July.

REPENS, L.

Rich meadows, fields, barren and waste places.

Creeping Triticum. Common.

var. NEMORALE, Anderson.

Woodland Triticum.

Thickets. On the verge of high cliffs along the Mohawk east of Spraker's, Montgomery county. Shaded upright steeps of Fall hill, Littlefalls, Herkimer county. Apparently native.

Scarce. June - August.

CANINUM, $L$.

Bearded Triticum.

Rocky banks. Littlefalls, Herkimer county. Watertown, Jefferson county. Fields. Penn-Yan, Yates county, Sartwell in herb. Ham. Coll.

Swamps. Sparingly at West-Bergen, Genesee county. Infrequent. July.

HORDEUM, $L$.

VULGARE, L.

Borders of fields, railroad banks.

SECALE, $L$.

CEREALE, L.

Remains in old cultivated fields,

ELYMUS, $L$.

VIRGINICUS, $L$.

Low flats of the Mohawk. Lake marshes.

CANAdENsis, $L$.
Barley.

Many-rowed, Common Barley. Frequent. July.

Rye.

Cereal Secale.

Often. June, July.

Wild Rye.

Virginian Elymus. Frequent. July, August.

Canadian Elymus. River-sides. Swamps on the hills south of the Mohawk valley. Abundant.

var. GLAUCIFOLIUS, Gray.

Pale-leaved Elymus.

Shores. Borders of Seneca lake, Gray. Yates county, Sartwell.

July, August.

STRIATUS, Willdenow.

Striate-stemmed Elymus.

Dry gravelly banks of streams. Oneida county, Knieskern.

var. villosus, Gray.

Villose-flowered Elymus.

Rocky hillsides. Bridgewater, Gray. Western part of the State, Gram. \& Cyp. Penn-Yan, Yates county, Sartwell. 
GYMNOSTICHUM, Schreber.

HYSTRIX, Schreb.

Bottle-brush Grass. ravine-sides, frequent.

July, August.

$\operatorname{AIRA}, L$.

FLEXUOSA, L.

Hair-grass. Bending Aira.

Rocks and dry sandy plains. Littlefalls, Herkimer county. Rome, Knieskern. Dexter, Jefferson county, Vasey. Western part of the State, Gray Gram.\& Cyp. Ontlet of Crooked lake, abundant, Sartwell.

Frequent. June.

CASPTTOSA, $L$.

Tufted Aira.

Rocky river-banks, lake shores. Pine plains between Albany and Schenectady. Watertown, Jefferson county, Gray Gram. \& Cyp. Dexter, Vasey. West-Canada creek, Fairfield. Herkimer county ; on the banks of the Muluawk below Utica; Gray. Crooked lake outlet, in a few localities, Sartwell. Along the shore of Lake Ontario. Abundant in the dry marl along the southern border of the West-Bergen swamp, Genesee county.

Rare. July.

DANTHONIA, DC.

SPICATA, Beauvois.

Sany plains, dry hillsides, pine and hemlock woods.
Wild Oat-grass. Spicate Danthonia. Frequent. July.

TRISETUM, Persoon.

SUBSPICATUM, Beauvois.

var. MoLle, Gray.

Downy Trisetum.

Sandy shores of the lakes, rocky river-sides. Borders of Irondequoit bay, of Lake Ontario, Monroe county, L. Holzer: C. M. Booth. Lake shore, Jefferson county, Crawe: Gray. Littlefalls, Herkimer county, Gray Gram.\& Cyp.

The station of both this and the following species was on the rocky banks of islands in the river, above the town. They could not have been native here : they belong northward and west, and must have come down the Mohawk and had the Great Lakes for their source. Many similar indications of the flora our valley confirm the testimony of the rocks, that in some remote geological period it has been an outlet of the Lakes, or a channel of retreating waters.

Rare. July.

PALUSTRE, Torrey.

Marsh Trisetum.

Shores and low mearlows. Little falls of the Mohawk, Gray. Ithaca, Tompkins county, Sartwell in herb. Ham. Coll. Rare. June.

AVENA, $L$.

Oat.

striata, Michaux.

Striate-sheathed Avena.

Shady rocks, ravine-sides, banks of streams. Chiefly among the hills, both north and south of the Mohawk. Littlefalls. Near Wood creek, Knieskern. Gulf of Chittenango creek.

Frequent. July.

$S \cdot A T I V A, \mathrm{~L}$.

Railroads, field-borders, wood roads.

HOLCUS, $L$.

\section{L.ANATUS, L.}

Moist banks.

ANTHOXANTHUM, L.

ODORATUM, L.

Roadsides, damp pastures.
Common Oat. Sown Avena. Self-sown often. June, July.

Velvet-grass.

Downy Holcus.

Occasional and transient. June.

Vernal-grass.

Fragrant Anthoxanthum.

Common. May-August. 
PHALARIS, $L$.

ARUNDINACEA, $L$.

Banks of streams, rivers, lakes.

MILIUM, $L$.

EFFUSUM, $L$.
Canary-grass. Reed-liive Phalaris. Frequent. July.

Millet-grass.

Scattered Milium.

Borders of swamps, banks of streams. Utica; Bridgewater; Gray. Oriskany, Knieskern. Potter, Yates county, Sartwell in herb. Ham. Coll. June.

PANICUM, $L$.

Panic-grass.

FILIFORME, $L$. Filiform Panicum.

Sandy shore of Lake Ontario, from Sodus point to Braddock's bay.

Rare. Angust, September.

GLABRUM, Gaudin.

Glabrous Panicum.

Barren sandy fields and banks. Common in uncultivated fields on sandy hilis east of Black river, Lewis county. Banks of the Erie canal, Knieskern. Shores of Oneida lake. Damp bluff's along Lake Ontario.

Frequent. August, September.

S.ANGUIN.ALE, L.

Finger-grass, Blood-stained Panicum.

Waste grounds, roadsides, streets.

Common. August - October.

PROLIFERUM, Lamarck.

Proliferous Panicum.

Lake marshes. Borders of Oneida lake, Knieskern. Salina, Onondaga county, G.W. Clinton.

Infrequent. August, September.

CAPILLARE, $L$.

Capillary-panicled Panicum.

Cultivated fields, sandy copses.

Common.

A depauperate form, one to three inches high, not branched at base but standing upright, bearing short narrow leaves and a close few-flowered panicle, grows in exsiccated swamps.

An intermediate form occurs on low shores.

August.

VIRGATEM, $L$.

Virgate-panicled Panicum.

Sandy shores. On an island in Oneida lake, Knieskern in herb. Sartwell Ham. Coll. Borders of Cayuga marshes, Seneca county. Banks of Clyde river, Ontario county.

Rare. August.

LATIFOLIUM, $L$.

Moist woods, hillsides, banks of streams.

Broad-leaved Panicum. CLANDESTINUM, $L$.

Damp thickets, shady ravine-bottoms.

var. PEDUNCULATUM, Gray.

Clandstine-flowering Panicum.

Frequent.

Under the cliffs at Littlefalls, Herkimer county. Penn-Yan, Yates county, Sartwell in herb. Ham. Coll.

July, August.

XANTHOPHYsUM, Gray.

Yellow-natured Panicum.

Culmo ( simplici aut basi ramoso) panicula foliisque glabris; vaginis villosis, foliis lato-lanceolatis valde nervosis acutissimis, basi ciliatis; panicula simpliciuscula pauciflora, ramis erectis vel adpressis; spiculis globoso-obovatis pubescentibus; gluma inferiore flosculis subduplo breviore, superiore eosdem æquante 9-nervi; flore masculo bivalvi hermaphroditum glabrum obovatum subæquante: Gray Gram $\&$ Cyp.

Whole plant light green, becoming yellowish in drying. Root perennial. Culm simple or branching from the base, $12-15$ inches high, glabrous. Leaves broad-lanceolate, 3-6 inches in length, 4-6 lines broad, acute, strongly nerved, ciliate at the base. Sheaths rillose, shorter than the joints. 
Peduncles elongated when old. Panicle sub-simple, few-flowered, with the branches appressed, nearly smooth; spikelets globose-obovate, as large as in $P$. latifolium. Glumes pubescent; the interior one oblong, acutish, 3-nerved, about half the length of the 9-nerved superior one. Abortive Horet staminifrous, 2 -valved; inferior valve equalling the superior glume; supcrior valve shorter, membranaceous. Perfect floret cartilaginous, rather obtuse, smooth and shining, equalling the superior glume: GrAY in Rare plants of Northern $\boldsymbol{N}$. $\boldsymbol{Y}$.

Pine barrens, along Wood ereek near Oneida lake, Gray. Hamilton, Madison county, J.S. Douglass: Gray in Rare plants of Northern N.Y.

Rare. June,

DICHотомUM, $L$.

Forking-panicled Panicum.

Dry borders of woods, sandy plains, barren thicket-land.

Common.

Many forms, smooth, shining, pubescent; one only two or three inches high, but full of fruit, on cold banks among lichens, in the north woods. June - September.

DEPAUPERATUM, Muhlenberg.

Few-flowered Panicum.

Shaded rocks and barren woodlands at Littlefalls, a large form. Sand-plains of Rome, Knieskern. Dry barren soil, western part of the State, Gray Gram. $\&$ Cyp. Penn-Yan, Yates county, Sartwell in herb. Ham. Coll. June.

CRUS-GALLI, L.

Shores, marshes, ditches, waste places.

SETARIA, Beauvois.

GLAUCA, Beauv.

Waste-grounds, yards.

VIRIDIS. Beauv.

A weed in cultivated fields.

CENCHRUS, $L$.

TRIBULOIDES, $L$.
Cock's-foot Panicum. Common. August-October.

Foxtail. Bottle-grass. Glaucous Setaria. Common. August.

Green Setaria. Common. July.

Dry sandy soils. Along the Central milnoad, and in cultirated ficlds betweer Al sany and Schenectady. Also in barren, andes of clear sand on plains, in advance of even Cyperus filiculmis. Rare. August, September.

ANDROPOGON, $L$.

FuRcatus, Muhlenberg.

Beard-grass

Pine barrens. Between Allony and Schenectady. Pine plains, Rome,Kni kern. Shore of Lake Ontario.

scoparius, Michaux.

Bur-grass. Job's Comforters. Tribulus-like Cenchrus.

Sterile ground, oll fielts. Comm to Littlefalls. Steep ridge-sides of Irondequoit bay, Monroe county.

Abundant. August, September.

VIRGINICUS, $L$.

Virginian Andropogon.

Barren banks, drained swamps. Yates county, Sartwell in herb. Ham. Coll. Rare. September.

SORGHUM, Persoon.

nutans, Gray.
Wood-grass. Indian-grass.

Drooping-fruited Sorghum.

Dry banks of the Mohawk valley, from Schenectady to Herkimer county. Sandy plains of Rome. Knieskern. Seneca lake, Gray. Penn-Yan, Yates county. Sartwell in herb. Ham. Coll. Shore of Lake Ontario, from Sodus bay to Braddock's bay, Monroe county. Frequent. Angust, September. 


\section{ACROGENS.}

Top-growers.

EQUISETACE $A$.

Horsetails.

EQUISETUM, $L$.

Equiseta.

ARVENSE, $L$.

Field Equisetum.

River and ravine-sides, low grounds along streams, embankments of railroads, sometimes in meadows.

Common. April.

SYLVATICUM, $L$.

Shady banks, wet woods, arbor-vitæ swamps.

LIMOSUM, $L$.
Woodland Equisetum. Abundant. May.

Mud Equisetum.

Low river-banks, miry marshes. Throughout the valley of the Mohawk. Occasionally in swamps on the hills.

Frequent. June.

\section{HXEMALE, $L$.}

Springy sidehills.

VARIEGATUM, Schleicher.
Winter-lasting Equisetum. Common. May.

Variegated-sheathed Equisetum.

Sandy shores. Steep banks of the Oriskany creek above the Dexter factories, near the base of the slope, in shade. On an island in Owasco lake, Cayuga county, I. H. Hall. All along the shore of Lake Ontario, from Sodus point, Wayne county, to Braddock's bay, Monroe county. Rare. April, May.

SCIRPoIdes, Michaux.

Scirpus-like Equisetum.

Wet banks and cedur swamps. College-hill, Clinton. Near the Chenango canal, three miles southwest of Utica. On the flats of the Mohawk, in the deep swamp between Utica and Frankfort. Fairfield, Herkimer county; a!so common in many places in Bridgewater, Gray.

Scarce. April.

\section{FILICES.}

Ferns.

POLYPODIUM, $L$.

VULGARE, $L$.

Rocks, ravine-sides, swamps.

Common Polypodium.

Frequent. August - October.

\section{PHEGOPTERIS, $L$.}

Beech Fern. Wood Polypodium.

Shady ravines, stream-bottoms, moist woods. Abundant. June, July.

\section{HeXagonopterum, Michaux.}

Six-angled-winged Polypodium.

Moist woodlands. Herkimer. Gray. Between New-Hartford and Paris hill.

Auburn, Cayuga county, I. H. Hall. Lodi, Seneca county, Gray. Gorham, Ontario county, Sartwell in herb. Ham. Coll. Abundant in the valley of Genesee river. Scarce. July, August.

DRTOPTERIS, $L$.

Tree-like Polypodium.

Moist banks along streams. Common in cedar swamps. 
STRUTHIOPTERIS, Willdenow.

GERMANICA, Willd.

Ostrich-fern.

German Struthiopteris.

Flats of water-courses. Common throughout the vallies of the Mohawk and all its creeks and tributaries. Alluvial bottoms of Fish ereek; where the sterile frouds form thickets five to seven feet high. August, September.

ALLOSORUS, Bernhardi.

Rock-brakes.

gracilis, Presl.

Slender Allosorus.

Clefts of rocks in shade and moisture. Helderberg mountains, $L$. Collins. Littlefalls, B. D. Gilbert. Wooded ledges between Littlefalls and Mud lake, Herkimer county. Trenton-falls. On Sugar creek near Boonville, Gray; and along Black river below Watertown. Cliffs of the Chittenango ravine, where it flourishes remarkably, hanging often a foot in length from its loold in the rocks.

Rare. July.

AtropurpdreUs, Gray.

Dark-purple-stemmed Allosorus.

Limestone rocks. Helderberg mountains, Pearson. Rocky sidehills at Spraker's, Montgomery county. Dry hills along Crooked lake outlet, Sartwell. Ithaca, Tompkins county, falls of East creek, Bradley.

Rare. July - October.

PTERIS, $L$.

AQUILINA, $L$.

Old sandy fields, bush-lands.

ADIANTUM, $L$. PEDATUM, $L$.

Woods, ravines.
Common Brake. Eagle-like-centered Pteris. Common. June - August.

Maidenhair. Pedately-branching Adiantum. Common. July, August.

\section{Virginian Woodwardia.}

Borders of swamps. Round Wetmore's pond on Frankfort hill. Swamps of Rome throughout. Junius, Seneca county, Sartwell in herb. Ham. Coll.

CAMPTOSORUS, Link.

внIZOPHYLLUS, Link.

Scarce. June - August.

Rocks in shade, swamps. Helderberg mountains, Pearson. Lofty cliffs of Bignose on the Mohawk, Montgomery county. Abundant at Littlefalls, both sides of the river: ledges on the hills sonthward, on the road to Warren: Herkimer county. Ravine of Chittenango creek.

In a cedar swamp west of Onondaga lake it abounds on old logs, stumps, knolls; stretching frequently eighteen or twenty inches the first time, and running on to the third and fourth generation : fronds occasionally forking. On rocks west of Otsego lake an unusual form has been gathered by $B . D$. Gilbert, having lobes springing from each side of the base of the main one, at right angles, four or five inches in length. Rare. July-November.

\section{SCOLOPENDRIUM, $L$.}

OFFICINARUM, Swartz.

Hart's-tongue.

Ravine of Chittenange creet, Inadison the cliffs. in moisture and shade.

This remains the only known locality in the United States of this fern so frequent in England and Europe. Not many plarts now are to be found; and they may be disappearing. Nature, however, well guards them from all danger and even access, save from the reckless and destructive botanist.

Another station has recently been discovered on the outlet of Lake Simcoe, Canada West. There, too, as in our hahitat, it occurs in a ravine below the falls of the stream, in the hunid atmosphere. Local. July-October. 
Limestone cliffs. Helderberg mountains, C. H. Peck. Rocky steeps and cliffs all along between Fonda and Palatine bridge, Montgomery county, common on both sides of the Mohawk, especially from Littlenose to Spraker's, and on the cliffs of Bignose: growing remarkably large, whole clusters of fronds hanging over six inches in length and three in breadth. Abundant at Littlefalls, on the precipices of the south side of the river, both in shade and exposed seats of the rocks. Cliffs of Chittenango creek.

Rare. August - November.

TRICHOMANES, $L$.

Maidenhair Asplenium.

Clefts of rocks in shade. Helderberg mountains, Pearson. Cliffs on the east side of Otsego lake, $B . D$. Gilbert. Littlefalls, south side of the river: ledges of limestone rocks near the summit of the hills southward toward Mud lake, Warren: Herkimer county. Trenton falls. Fish creek precipices. Chittenango ravine rocks, Madison county.

Searce. July - December.

EBENEUM, Aiton.

Ebony Asplenium.

Edges of rocks. Schenectady county, Pearson. Littlefalls. north side of the Mohawk. Chittenango creek, west side of the ravine. Hector, Tompkins county, Gray. Ithaca, Tompkins county, Sartwell in herb. Hain. Coll. Parma, Monroe county, Bradley.

Frequent. July - October.

\section{ANGUSTIFOLIUM, Michaux.}

Rich woods and deep ravine-bottoms.

THELPPTEROIDES, Mich $x$.

Moist woods.

FILIX-FEMINA, $R$. Brown.

Woods.
Narrow-fronded Asplenium. Abundant. July - September.

Lady-fern-like Asplenium. Abundant. August.

Female Fern.

Common. July - September.

DICKSONIA, L'Héritier. PUNCTIL OBULA, Hooker.

Dotted-lobed Dicksonia. Damp woodlands.

Common. July.

WOODSIA, R. Brown.

Woodsias.

oBTUsa, Torrey.

Obtuse-lobed Woodsia

Rocky woods and banks. Cliffs along the east side of Otsego lake, B. D.

Gilbert. Ithaca, Tompkins connty, Sartwell in herb. Ham. Coll.

Infrequent. July.

ILVENSIS, $R . B r$.

Isle of Elba Woodsia.

Clefts and shelves of rocks. Cliffs of Otsego lake. Abundant at Littlefalls, on the cliffs of the north side of the river. Alexandria bay, Jefferson county. IEhaca, Tompkins county, Sartwell in herb. Ham. Coll. Uncommon. June.

GLABELLA, $R . B r$.

Smooth Woodsia.

High on the cliffs at Littlefalls, south of the Mohawk, in rock soil and evergreen shade: discovered at this station more than twenty years ago, by VASEX.

The rarest of our ferns, next to Scolopendrium, and more inaccessible. It is scattered along the brow of the lofty cliffs of Fall hill, nearly all out of reach. In delicacy, grace, beauty, it certainly has no rival. Local. June.

CYSTOPTERIS, Bernhardi.

BULBIFERA, Bernh.

Bulb-bearing Cystopteris.

Ravine-sides and rocky banks.

Cummon, July - September.

[ON, PL.] 
Fragilis, Bernh.

Brittle Cystopteris.

Clefts of wet rocks. gravelly shores of streams, stony hillsides, and sonetimes in black-ash swamps.

Abundant. July, August.

var. DENTATA, Hooker.

Dentate-lobed Cystopteris.

Dry rocks. Below Utica, at the summit of the valley hillside, on outcropping sandstones in crevices of the barren surface.

Rare. June.

\section{ASPIDIUM, Swartz.}

Shield-ferns. Aspidia.

THELYPTERIS, Swart $z$.

Fences, pastures, along streams, swamps.

Lady-fern.

NOVEBORACENSE, Willdenow.

Common. July - October.

Marshes and shady moist woods.

New-York Fern.

DilataTUM, Willd.

Abundant. July - September.

Deep woods and horders of hioh swamps. Also formerly gathered in Yates county by Sartwell.

SPINULOSUM, Swartz.

Ravines and woods.

Broad Aspidium. Infrequent. August.

Spinulose Aspidium. Common. August - November.

вооттII, Tuckerman.

Discovered by William Bootт.

Rather large, outline oblong, stipe chaffy; frond smooth; somewhat $3^{-}$ pinnate; pinnules oblong-ovate, acutish, pinnatifid; segments sharply toothed, teeth mucronate; sori rather small, distinct, somewhat reniform: Tuckerman in Hovey Mag.

Rich low woods on the Mohawk river-bottoms, a narrow form and one which is quite scarce. A shorter state of the same form has been gathered on the borders of swamps on the hills of Delaware county, by B. D. Gilbert.

A form only a little larger than specimens from the original locality of this species is abundant in all deep rich woodlands. Frequent. August, Sept.

Cristatem, Swartz.

Shield, Crested Aspidium.

A long narrow form, the old $A$. lancastriense, is rare in arbor-vitæ bogs in the valley of the Mohawk. Around marshes in Delaware county, B. D. Gilbert.

The broad-fronded plant is common in upland swamps. Borders of the open marsh-land north of Summit lake, Otsego county. Cedar swamp east of Mud lake; on the marshes of Jordanville, Warren; around Hidden lake, Litchfield; and in open bogs on Frankfort hill, near Wetmore's bear-pond; Herkimer county. Frequent in the cold marshes east of Fish creek, and near Point of Rock lake, and throughout the northern part of the county.

Scarce. July, August.

var. MAJUS, Eaton, ined.

Greater Crested Aspidium.

Low rich woods : common on the flats of the Mohawk; and occasionally of the streams and creeks emptying into it.

GOLDIEANUM, Hooker.

Deep rich ravine-bottoms.

MARGINALE, Swartz.

Gulf-sides, rocks.

ACrostichoides, Swartz.

Wooded banks.

var. INCISUM, Gray.

Shady swamps and stream-sides.

Fronds of this variety, having all the pinna fruitful, hate been gathered along ravines two miles southeast of Utica; and on the sides of a gulf on Cellege hill sonthwest of Clinton.
Frequent. Angust - October.

\section{Discovered by GOLDIE.}

Frequent. July, August.

Marginal-fruited Aspidium.

Common. July - September.

Acrostichum-like Aspidium.

Common.

Incised-lobed Aspidium. Frequent.

Rare. July - November. 
ONOCLEA, $L$.

SENSIBILIS, $L$.

Wet woods and swamps.

var. овтUsiloватA, Torrey.
Sensitive Fern. Frost-sensitive Onoclea.

Common. July. Rounded-lobed Onoclea.

Marshy woodlands east of Onondaga lake.

In herb. Sartwell Ham. Coll. is a fine specimen of this'varjety in full fruit, from Salem. Washington county, J. Smith. Also two other specimens from Penn-Yan, Yates county, Sartwell, of the same form, but without fruit. Many fronds of the same form with these, and corresponding exactly with each of the figures in Torrex's $F l . N . Y$., having free veins and sornetimes indusia, have been gathered in the swamps and woods near Salina.

The abnormal form having both sterile and fertile pinnæ on the same frond, often one side all sterile and the other all fertile, in the regular form, are not rare. July, August.

OSMUNDA, $L$.

REGALIS, $L$.

var. SPECTABILIs, Gray.

Wet meadows and swamps.

CLAYTONIANA, $L$.

Low grounds and damp woods.

CINNAMOMEA, $L$.

Swamps.

var. FRondosa, Gray. Occasional in wet woods around Utica. Abundant on low sandy clearings west of Fort Bull, Rome.

BOTRYCHIUM, Swartz.

LUNARIOIDES, Swartz.

Sandy pastures and banks.

A mong bushes, the fertile of sixteen inches, with sterile frond nine inches high and six broad.

Plants of the ordinary size occasionally are found with two, and rarely with three perfect fertile fronds, all of the same size, springing together from the stipe of the sterile frond near the root.

var. Dissectum, Gray.

Cut-lobed Botrychium.

Grassy banks of a stream in a pasture near Fall brook, three miles north of Taberg.

VIRGINICUM, Swartz.

Moist woods. Rare. August - October.

Virginian Botrychium. Common. June, July.

lanceolatum, Angström.

Narrow-lobed Botrychium.

Roots many, thick and chordlike, dark brown. Stem enlarged the base just above the roots, tapering upward into a stout erect stipe, bearing the fronds at its summit. Sterile frond either many times divided to the midrib into lanceolate lobes with its lobes incised, about an inch in width and length, triangular in outline, or in the largest specimens consisting of three branches springing together from the stipe or the lateral from the very base of the middle one, spreading an inch and a half, all parted widely into narrow lobes more or less cut upwardly. Fertile frond always similar to the sterile; terminating the stipe, or in the largest plants the stem forking into three branches, all about an inch long and parted into many fruit-lobes.

Sandy mounds in clearings and fields. In a pasture three miles north of Taberg.

Rare. June. 
SIMPLEX, Hitchcock.

Simple-fronded Botrychium.

Frond simple, 3 -lobed or 3 -cleft; segments unequal ; spike subcompound, interrupted, unilateral, bearing sessile capsules of the size of a nustard seed.

Frond solitary, from a torn membranous sheath, erect, two to four inches high, glabrous, pale green, consisting of a small spatulate leaf an inch long and one-third of an inch broad, usually divided into three, rarely four, unequal, somewhat rounded segments, with their margins a little notched. From the base of the leaf, about an inch from the ground, springs a stalk, twice or thrice the length of the leaf, bearing a subcompound unilateral interrupted spike of capsules, sub-tworowed. Root sending forth stout simple fibers: Нгтснсоск in Sill. Jour.

Most of the plants found in the following stations are of the lowest forms and extremely variable; from one to seven and a half inches high. Sterile frond usually remote and always separate from the spike; in the smallest specimens a minute spur just under a single spore-case terminating the short stem; in larger plants an oblong entire bract, lower on a stipe bearing a few sporangia; in ordinary forms springing from below the middle of the stipe, short-stalked, half an inch long, once incised or parted more or less deeply, with its fertile spike branching at base ; in the largest specimens rising from the stipe near the root, long-stalked, an inch and a quarter in length, three-fourths of an inch broad, four times pinnately divided, the lowest lobes separate from the higher and all enlarged at the end, its fertile frond terminating the long stalk, two inches in length, having three or four pairs of branches, the lowest branching in turn. Stem slender, weak, bending with the fruit.

Cedar swamps : shady borders of the State marsh near Jerusalem hill, Litchfield, Herkimer county; on moss-covered bogs and mounds.

Pastures: near Fall brook, west of Fish creek. Rare. May, June.

\section{OPHTOGLOSSUM, $L$.}

VULGATUM, $L$.

Adder's-tongue.

Fronds of all forms from orbicular and oval to elliptical-lanceolate; often four inches in length, stems sometimes over a foot high.

Spikes occasionally with only a few sporangia at base, above becoming a secont frond, three or four lines wide, an inch and a half long.

Dwarf forms occur, having a very short stipe, and a spike only half as high as the frond is long.

Pastures east of Mud lake, Warren; damp banks among arbor vita on the shores of Cedar lake, Litchfield; south Herkimer county. Grassy ridges on the Deerfield hills, opposite Utica. Nossy bogs in the old Oriskany swamp. Copses and rich mounds near Fall creek, north of Taberg. Dry hills between Brownville and Dexter, Jefferson county. Marshes at the foot of Owasco lake, Cayuga county. Open woods in Henrietta, Genesee county.

The dwarf form at Exeter, Otsego county, Torrey Fl.N.Y.; and in the Fall brook pasture, west of Fish creek. Rare. June, July.

\section{LYCOPODIACE无.}

Club-mosses.

LYCOPODIUM, $L$.

LUCIDULUM, Michaux.

Lycopodia.

Mossy banks, raviue-sides, moist woods. Common. August-December.

\section{INUNDATUM, $L$.}

\section{Overflowed Lycopodium.}

Bogs and marshy borders of ponds. North Herkimer county, on the wet flats surrounding elevated ponds at each end of Bald rock, north of the first three in the chain of Eight lakes, a form with short forking stems, and small narrow weak entire erect leaves. 
Five miles west of Rome, at the border of the swamp. beside the Watertown railroad. along the base of a bank of excaration facing the north, on damp sand, a form with long straight stems and large broad rigid sharplytoothed spreading leaves; abundant, though of recent appearance in this a newly-made station.

Rare. September, October.

ANNOTINUM, $L$.

Year-marked Lycopodium.

Deep woods. Frequent, but more abundant on the hills.

August, September.

DENDROIDEUM, Michaux.

Sandy fields and woods.

CLATATCM, $L$.

Barren, old open thicket-fields.

COMPLANATUM, $L$.

Sidehills, sandy or rocky openings.
Tree-like Lycopodium. Common. August - November.

Club-fruited Lycopodium. Comraon. Angust - October.

Flattened-fronded Lycopodium. Cummon. September - November.

SELAGINELLA, Beaurois.

RUPESTRIS, Spring.

Selaginellas.

Rock Selaginella.

Dry open rocks. Littlefalls, north side of the riser. Alexandria bay, Jefferson county.

Rare. August - October.

APCS, Spring.

Stemless Selaginella.

Thet banks. Abundant round Cedar lake, Litchfield, south Herkimer county. Sandr borders of swamps, Rome, Knieskern. About Salina, under the Solar Salt-works.

Scarce. Angust.

\section{MARSIEACE $\mathrm{E}$.}

\section{ISOETES, $L$}

LACUSTRIS, $L$.
Marsiteads.

\section{Quillwort.}

Lake Isoetes.

On rocks on the bottoms of rivers : New-Tork, in the Oswego river near the the falls, $v . v$. Pursh.

This plant was so named when all forms were considered the same, and identical with $I$. lacustris of Europe. Among the species of our time, it must belong either to I. echinospora or to I. braunii, DrRIET; closely allied species, the chief distinction being in the small needle-like projections of the spores, which in the former are compressed, somewhat flattened and very fragile; in the latter they are conoid and much firmer : both distinguished, by soft light green or even yellow leaves which are gradually subulate, from $I$. lacustris, whose leares are dark green, rigid, and more linear throughout.

Rare. August, September.

\section{AZOLLA, Lamarck.}

CAROLINIANA, Willdenow.

Carolinian Azolla.

Stagnant water and miry banks. In all the side-maters of Lake Ontario, from the marshes fire miles northeast of Oswego, to Braddock's bar, Monroe county : often completely covering the water with a purple velvet mantle.

Common near the shore, but not obserred at ans distance from the Lake. 


\section{A D D E N D A.}

To

Atragene americana, p. 1, the stations:

Aloug the cliffs of Bignose point on the Mohawk, Montgomery county. On a hill above Unadilla-forks, Otsego county, Gray.

Before Clematis Virginiana, p. 2, the species:

ochroledea, Aiton.

Yellow-white-flowered Clematis.

Sandy hilly woods, westward of Crownpoint, Essex county; where it was discovered by G. T. Stevens.

To ANEMONE CYLINDRICA, the stations:

Abundant on the Pine plains between Albany and Schenectady. Near Owasco lake, Cayuga county. I. H. Hull. Shore of Lake Ontario near Irondequoit bay, Monroe county.

To A. PENNSYlVANicA, the stations:

Marshes of Jordanville, Warren; and around the East Dry-lot pond, Litchfield, Herkimer county. These are localities without inlet or outlet, and have no connection with streams either northward or southward, on the summits of our highest hills : remarkable for a plant usually occurring along the largest streams and Lake shores.

Also frequent in southern Oneida county and the adjacent parts of Otsego and Madison counties, Gray.

To RandNCULUS AQUATILIs, var. DIVARICATUS, the range :

Abundant in the inlets and bays of Lake Ontario, from Oswego to Braddock's bay, Monroe county.

To R. PURSHII :

This species received the name $R$. lacustris from L. C. BECK and J.G. TraCy a little earlier than the present one from RICHARDson. This was given in the second edition of Flora of the Polar regions, of which the first edition was published in 1823 .

One of the first papers read before the Albany Lyceum of Natural History was a description of this new species of Ranunculus; which afterward was published in the New-York Medical and Physical Journal for January 1823, as follows :

RANUNCULUS lacustris. Leaves all submerged, alternate, dichotomously divided into numerous capillary segments; with clasping membranaceous stipules. Peduncles emerging, dichotomous, slightly furrowed. Flowers terminal, large. Calyx spreading, hairy, fleshy, caducous. Petals five to eight, obovate, larger than the leaves of the calyx, and larger than those of $R$. bulbosus. Nectary petal-like, cucullate-tubular, nearly equalling the length of the filaments. Fruit oval. Stem floating, branched, glabrous, hollow, round, from two to four feet in length, extending radical fibres from the lower joints. Roots fibrous, short.

Ha iтыт. In a stagnant pond near Lansinghurgh on the IIndson river, and in a similar situation near Lewiston on the Niagara.

On the appearance of Hooker's Flora Borcali Americana, which adopted R. purshii, these gentlemen reaftirmed their name, with another description and a plate, in the Transactions of the Albany Institute.

The plant also occurs in marshes east of Onondaga lake, and along the shore of Lake Ontario. In Sodus bay, it grows high on a sandy point, and changes its character for the place, having a creeping underground rootstalk, sending up crect stems bearing two to four petioled leaves, which are nearly half an inch broad and twice notched at the end, or the highest sessile, obovate, entire. 
Abundant on a long peninsula running out into Sodus bay, just inside the point, covering low sandy banks in thick patches, with Eleocharis olivacea and Scirpus pauciflorus, in a grove of Populus monilifera. The small form : stems and carpels often downy.

To Magnolia acuminata, p. 5 , the range :

Occasional throughoat Cayuga, Wayne and Monroe counties; most frequently along streams or near the shores of lakes, but sometimes in high forests.

To Nelumbium luteum, p. 6 :

More particularly the station of this noble plant at Sodus bay is near the head on the east side, above and below the ruins of an old bridge, extending down across the present ferry and on towards the wharf, covering an acre or more.

Most of it is near the marshy shore in shallow water, with leaves, flowers and fruit elevated above the surface by high rigid petioles and peduncles. The leaves have a peculiar velvety surface that cannot be made wet, on which, at morning, the dewdrops glisten brighter than gems in the sun, and present a most beautiful sight. The flowers are immense, nearly white, and are truly splendid. So indeed they are regarded by the numbers who go from far and near to gather them all summer. Yet the plants seem to be not only flourishing, but on the increase, spreading along the shore in both directions by its huge tuberous roots.

July - September.

To Brasenia peltata, the range :

Frequent in the ponds and marshes bordering Lake Ontario, from north of Oswego, southward and westward.

\section{After Nrmphea odorata, the variety and species:}

The remark "sometimes in mud, with erect leaves and flowers", "Cedar lake and Hidden lake", refers to

var. MINOR, Sims.

Smaller Fragrant Nymphaa.

N. MINOR : foliis cordatis integerrimis, subtus nervis venisque prominentibus, pedunculis petiolisque pilosiusculis, stigmate 16 -20-radiato.

Rhizoma horizontale, repens, oblongum. Petioli teretes, pilosi. Folia glabra, superne intense viridia, subtus purpurea, cordata, obtusissima, auriculis magis divaricatis et acuminatis quam in N.odorata. Pedunculi pilosi. Flores minores quam $\mathbf{N}$. odorate, extus rosei in planta spontanea ex cl. Purshio, albi in individuis cultis ex radicibus ab ipso Purshio in Angliam adsportatis. Cl. hortulanus Anderson qui plurimas Nymphæaceas diu et feliciter coluit hanc speciem ab odorata distinctam pronunciavit, et ipse Purshius ab hac opinione non recedit : DeCandolle Systema.

Plant small in all its parts. Leaves cordate, ovate, three to four inches in diameter, a little longer than broad, smooth both sides, green above, deep red-purple beneath, with prominent radiating veins, seven of which are basal and five from the midrib on each side; lobes approximate, frequently overlapping, rounded or often ending in a short point. Flowers diminutive and delicate, from one to two inches in length; sepals brown; petals white, or sometimes the outer tinged with pink externally, very fragrant, with the odor of honey. Ovary spherical, filled with light-colored loosely-arilled seeds. Upper part of the peduncles and petioles villose or thick downy, and more or less pubescent below. Stipules red, longer than broad, ovate, lacerate at end, thick-membranous with scarious margins. Rhizoma slender, three-fourths of an inch in diameter, covered with very fine dense hairy pubescence; branching frequently, of a dingy-pink color.

The Water-lily of Otsego, south Herkimer and Madison counties. On Hidden lake it inhabits shallow mossy pools, lifting its flowers and leaves above water by peduncles not more than a foot in length; but in deep water, its habit is the same with the typical plant, 
In the north woods of Herkimer, II amilton and Essex countirs, all lakes ponds, malshes are full of a Nymphoea, which doubtless is this variety: if' so, the true $\boldsymbol{N}$. "durata has not been ohserved in this State west of the valley of the Hudson river. June - August.

The plant referred to as "The variety with inodorons flowers", is the following :

TUREROSA, $s p . n o v$.

Tuber-bearing Nymphaa.

Rhizomate longe repente crasso e latcribus tubcrifero, stipulis lunatis multum oblique decurrentibus ubique relictis; foliis orbiculatis subtus prominenter venosis, auriculis sapissime acuminatis; floribus pæne inodoris; connectivo staminum exteriorum supra antheram in cuspidem elongato; arillo seminum obsoleto vel brevi cupulaformi rarius completo.

Rhizoma deeply imbedded in mud, runnirg horizontally, sending down in clusters long chord-like roots furnished with innumerable fibrous radicles, rarely branching, three to six feet long, one to two inches thick, varying in size but not regularly interrupted, with an uneven surface, somewhat compressed, scattered with short pubescence, bearing tubers from its sides, which are frailly connected by their bases narrowed into necks only one to three lines in diameter, usually short, often half an inch in length. Tubers oval, one to three inches long, half to three-fourths of an inch thick, with a rough tubercular surface, the tubercles elevated just back of the buds of elementary leaves, arranged in eight perpendicular series with five spiral rows in one direction to three in the other, bearing both roots and tubers when present; the tubers often in clusters from being repeatedly proliferous, sometimes occurring so frequently as to conceal the trunk, becoming separate plants when detached. Stipules in the axils of the petioles and embracing them by long lobes, shorter than broad, crescentshaped, with thin wavy margins. Petioles and peduncles striate with nerves and crimson veins, often pubescent above in lines with long silky purple hairs. Leaves of two forms : submerged form short-petioled, thin and transparent, the lobes divaricate and forming a right-angle at base ; floating leaves large, from eight to eighteen inches in diameter, exactly orbicular, sometimes retuse with sides contracted becoming angular, entire or undulate margined, green with a dark centre and even above, light-green or a little yellow below, with prominent nerves of which on each side twelve radiate from the centre and five to seven from the strong channelled midrib, sometimes having a few brown hairs along the veins and edges of the division; lobes approximate, parallel, or meeting in the largest forms, ending with an acute point and a sinus. Flowers two to four inches long, expanding four to seven, exhaling a slight vanilla-like fragrance at opening, but soon inodorous. Sepals four, green without, light within, as long as the flower. Petals many, the outer tinged with green externally, the inner snow-white, oblanceolate in outline, delicately straight-veined. Anthers yellow, long with converging cells, the connective elongated into a minute red cusp. Appendages of the stigma sixteen to twenty, short, obtuse, at first ascending and lying against the filaments, soon curving over as many rays of the disk. End of the central axis short, a line or more high, convex. Capsule globose or oblate, when maturing drawn to the bottom by the spiral coiling of the peduncle. Seeds acorn-shaped, red, with the usual raphe. Arillus defective, commonly a shallow cup surrounding the base of the seed, sometimes investing it halfway, or occasionally a mere rudiment, and rarely complete.

A larger plant than the other species, equal in beauty but wanting in fragrance. From $N$. odorata, var. minor, of course it is as remote as possible in every part. From $N$. odorate itself, it differs in its peculiar tubers, great leaves, large flowers of little odor, and imperfect arils. From N. alba of Europe, in addition to the tubers, it is separate by a continuous stem instead 
of one vertical at first, leaves so highly veined, a slight odor of flower, and the usually incomplete arilius. So similar, however, is it to the latter, that it seems to have been considered the same by NeTTALL in the single locality he rceords. The root-stalks prolong themselves indefinitely, yet only short portions are vigorous supporting leaves and flowers, the old parts declining as fust as the young ends increase. The tubers, too, attain a certain size, then wait to be broken off or to' be separated by decay. Their multiplication in clusters occurs only on remaining tubers; and all, if not by any cause removed, when they have reached maturity, do not grow any larger, remaining inactive until they die with the old root. But when liberated, they float about to some new bank; as soon as striking it, shooting down rootlets and sending out their already developed delicate submerged leaves, soon to be followed by others for the surface. These tubers, somewhat resembling those of Helianthus tuberosus or of Boussingaultia baselloides, are always present, sometimes few and single, usually frequent and abundant : as many as thirty have been counted on a section of rootstalk only six inches in length. By the slightest disturbance, they loosen and rise to the surface, and can be secured in place only by the greatest care in removal. The leaves would easily be recognized from others by their shape and appearance, as well as by their peculiar venation and remarkable size, largest in the bays of Lake Ontario, at Sodus bay rivalling even those of Nelumbium luteum; in imitation of which, also, both leaves and flowers rise high above the surface on stout stems in shallow water. The flowers may truly be termed magnificent, but their odor is faint and transient. The coiling of the flowerstems in deep water is more striking and complete than in the scapes of Vallisneria spiralis, though not so uniform; drawing the ovaries not only under water, but to the very ground; a habit that will be verified by any success of obtaining fruit in autumn. The trunks of this plant are soft and pliable, composed of a cellular or pithy substance which is very astringent. Cattle devour its immense leaves, venturing far into the water for them: in like manner, the deer of the north woods come down from the hills to the lakes at night to feed on the lily-pads so abundant there.

The Water-lily of Western New-York and the Great Lakes. It has been found : in St.Lawrence river, at Alezandria bay, Jefferson county: in Lake Ontario; filling all marshes beyond the shore for miles northeast of Oswego, where it was observed in 1861 ; in the bays of Wayne county, most abundant in the channels at the head of Big Sodus bay; plentiful in Irondequoit bay, throughout the swamps among the ends of ridges westward formed by streams setting back against bars thrown up by the waves, marshes of Charlotte in the mouth of the Genesee river, common in Round pond, Long pond, Cranberry pond, aud Braddock's bay, Monroe county : in Niagara river below Buffalo, by G.W. Chinton : in the Detroit river, by J. M. Bigelow : in Western New-York; farthest east in Oneida lake, where it is abundant near its head a little west of South bay, in marshes of Dianthera americana and Scirpus lacustris; all along the sides of Oswego river; frequent in the outlet of Owasco lake, and occasionally in the lake itself; common in the marshes of Cayuga river and lake; Clyde river through Wayne county; at Branchport, foot of Crooked lake, by SARTwELL; in Canandaigua lake, more abundant however in its old closed outlet; in Genesee river above Rochester, by DEWEY.

Late-flowering; in the waters of Lake Ontario the flowers not appearing until August, and abundant throughout September; but inland earlier, July and August.

Frequent.

To Nuphar Kalmiana, the habitat :

Common in the marshes of Oneida lake, in deeper water, farther out than N ymphaa tuberosa.

Before Cheltdonidm M.AJUs, p. 7, the species :

ARGEMONE, $L$.

$M E X I C A N A, \mathrm{~L}$.

Prickly Poppy.

Mexican Argemone.

Frequently spontaneous in cultivated grounds and waste lots in Auburn Cayuga county, I. H. Hall. July-September.

To NAsturtidM LACUstre, p. 8, the range :

Common in all inlets and bays along the southern shore of Lake Ontario.

[ON. PL.]

18 
After T'HLAspi ARVENSE, p. 10, the species:

CAKILE, Tournefort.

AMERICANA, Nuttall.

Sea-rocket,

American Cakile.

Sandy beaches. Frequent on the shore of Lake Ontario, from a few miles north of Oswego, to Sodus point, Wayne county, where it is in force, and Braddock's bay, Monrue couty.

July - October.

To Parnasia caroliniana, p. 12, the stations:

A bounding in an extensive swamp among the hills of Warren, near Jordanville, south Herkimer county: the only station that has been observed south of the Mohawk valley.

Before Medicago LUPULIN.A, p. 20, the species:
S.ATIV.A. L.
Lucerne. Purple, Sown Medicago.

Gravelly banks, borders of grass-lands. Deerfield creek, in meadows on the thats and on sloping bases of the gulf-sides. scarce. June, July.

After Phaseolis perennis, p. 22, the species :

diversifolius, Persoon.

Varied-leaved Phaseolus.

Shore of Lake Ontario between Irondequoit bay and Charlotte mouth of Genesee river, Monroe county, on a low sandy bar thrown up by the water, at the shady base of a ridge-side and along the end of a marsh near its outlet.

A small dwarfed state, only a foot and a half long, prostrate, having entire dark green leaves, peduncles shortened, no longer than the petioles, borne in the axils throughout the length of the stem, all bearing large deep-purple flowers with keels curving to one side : a singular and very pretty form.

Rare. August, September.

To Apios tuberosa, the habitat:

Common on the borders of marshes northeastward of Oswego, and abundant westward near the Lake shore.

To Cassia marilandica, p. 23, the station :

Banks and hillsides west of Owasco lake, Cayuga county.

After Potentilla Norvegica, p. 25, the species:

PARADOXa, Nuttall.

Strange-fruited Potentilla.

Decumbent at the base, pubescent ; leaves pinnate; leaflets $7-9$, obovateoblong, incised, the upper ones confluent; stipules ovate, mostly entire ; peduncles (alar) solitary, recurved in fruit; calyx-segments all nearly equal, acute, about the length of the obovate petals; receptacle villous; achenia striate, 2 -lobed, the lower portion (the enlarged base or insertion filled with starch) as large as the proper carpel : Nutral, mss. in Torr. \&. Gray $\mathrm{Fl}$.

Specimens of ordinary size have single erect stems cymosely branching; but the largest plants send out two to five in addition, which are prostrate and spreading. Leaves all radical. Flowers small. Appendages to the achenia quite conspicuous.

Sandy shores. Beach of Lake Ontario at Bradduck's bay, Monroe county; abundant on the point between the bay and the lake.

Rare. July - September.

Before LyThrum salicaria, p. 28, the species:

AMMANNIA, Houston.

Ammannia.

HUMits, Michaux.

Low Ammannia.

Bog-borders. Around sandy pools and banks of rivulets in the Pine barrens between Albany and Schenectady, near the Central railroad and Centre station. Rare. July, August. 
To MYriophyLLUM VERTicillaum; p. 29, the range :

Common in the lakes of the western part of the State and waters of Lake Ontario,

On Opuntia vulgaris, p. 30, the remark :

It is quite improbable that this plant ever was found native on the high cold hills of Fairfield. Professor Gray regards it as altogether impossible : certainly he was perfectly acquainted with the flora of that region at the time of this reference, and wonld have known it had it been in existence there. Dorbtless it is confined to the valley of the Hudson river, and its most northeru locality may be West-Point, Orange county, or possibly Hudson, Columbia county.

To Viburnum pubescens, p. 36, the habitat:

Abundant on the rocky steeps between Yost's and Palatine bridge, Montgomery county.

To Valeriana sylvatica, p. 38, the station :

In extensive tamarack marshes among the hilltops of Warren, south Herkimer county; where it occurs in great quantity, often growing in patches.

After Aster simplex, p. 40, the species:

TENUIFOLIUS, $L$.

Narrow-leaved Aster.

Swamps of Jordanville, south Herkimer county, where it abounds.

Rare. August.

After Solmago speciosa, p. 41, the species :

VIRGA-AUREA, $L$, var. HUMILIS, Gray.

Dwarf Goldenrod.

Swamps on the hills south of the Mohawk valley. On the State marsh, Litchfield, Herkimer county.

Rare. June, Juiy.

To S. OHIOENSIS, the station :

Common in the dry marly portions of the West-Bergen swamp, northeastern Genesee county.

To BIDENS BECKII, p. 44, the station :

Outlet of Owasco lake, Cayuga county, I. H. Hall.

After ARtemisia VULG.ARIS, p.45, the species:

BIENNIS, Willdenow.

Biennial Artemisia.

Barren banks. Oswego, G.W. Clinton. Adventive at all stations in this State. Rare. August - October.

To ONOPORDon ACANTHIUM, p. 46, the station :

Ledges of limestone, and roadsides near Page's corners, on the hills of Warren, south Herkimer county.

After Campandla rotundifolia, p. 48 :

On dry steep sides of high ridges west of Irondequoit bay, Monroe county, has been gathered a Campanula of unusual size and character, having a strong rigid erect stem three to four feet in height, with linear leaves three to five inches in length, deeply channelled and curved, bearing in the axils clusters of smaller leaves, and, from the very root to the top of the stem, simple branches ending in long slender peduncles of one to three small nodding terminal flowers.

June - August.

After Prrola secunda, p. 51 :

The plant referred to by the remark "In the high cold cedar swamps of Summit lake", \&c., is thought worthy of being designated as

var. PUMILA.

Slender Onesided-flowering Pyrola.

Stems three to five inches high, erect, not reclining at base. Leaves in two or three annual clusters; most always just circular, but sometimes broader 
than long notched, and sometimes oval a little longer than broad obtuse, fincly crenulate, quite thin, of an extremely light green color above, pale beneath; in marked contrast with the dark green, coriaceous, elliptical leaves of the common $P$. secunda, which merge into the petiole and are mucronate-acute at end. Scape slender; with two or three minute pointed bracts. Racemes strictly erect, three- to eight-Howered, very loose; flowers hanging usually on one side, narrowly cylindrical, pale green; anthers carried beyond the petals by long deep purple shining filaments; styles far exserted.

On damp moss under the shade of tamaracks and arbor vita, in all the large marshes among the hilltops between the vallies of the Mohawk and Susquehanna rivers, from above Summit lake, Otsego county, to the swamp near Cedar lake, sonth Herkimer county.

This remarkable diminutive variety, growing in moss of deep bogs, with thinner orbicular and more serrulate leaves of only half or three-fourths of an inch in diameter, much like those of Moneses uniflora, the slender scape only four-to nine-flowered, is very distinct in appearance, and must be the same with the "Varietas pumila biuncialis, foliis ad basim confertis orbiculatis in petiolum brevem decurrentibus serratis", of CHAMrso, in LinNeA, collected at Eschscholtz bay in Russian America, and which LEDEBodr in Flora Rossica cummends to further observation as to whether it may claim to be a distinct species. The leaves in the New-York specimens, however, are nearly all purfectly rounded at the base. Among the specimens in my herbarium, I find this form only from Labrador, Dr. Storer; North shore of Lake Superior, C. G. Loring jr.; and from the Northern Rocky mountains coll. Bourgeau : Gray.

To, Utricularia GiBBA, p. 52 :

This plant differs remarkably from other species, in mode of inflorescence. Others continue to flower by prolonging their racemes; while the scapes of this species are only one- to three-flowered. Yet it remains longer in flower than any other, by sending up an indefinite series of scapes frorn a disk-like centre among the roots; so that on one side of the flowering stem may be found a decaying old one in fruit, and on the orher a new one springing up, from

June to September.

\section{To Polemonium ceruleum, p. 63 :}

This plant, so rare eastward, and remarkably separated from its home in the northwest and among the Rocky mountains, has again been found by Mr. Gilibrert in Delaware county, among the hill-tops of Meredith, on the borders of several swamps.

All these stations prove the plant to be usual about the springs and marshes on the high cold hills between the headwaters of Oleout and Schobarie creeks, and southeastward berween the Susquehanna and Delaware rivers. The lowest pass over the latter is 2150 feet above tidewater, and the heights of these rolling ranges of hills eannot be less than 2500 feet.

Thus this section, with the exception of mountains, is indicated to be the most elevated in the State, by the subalpine Polemonium, as well as actual measurements. The level of the northern wilderness is only from 1500 to 1800 feet above the sea: Raquette lake, the source of Raquette river flowing northward to the St.Lawrence. is elevated 1745 feet; the chain of Eight lakes, headwaters of Moose river, arerage about 1700 feet; the two lakes that give rise to Black river. emptying into Lake Ontario, stand 1820 feet; and Jock's lake, fountain of West-Canada creek and the highest lake in the woods, is 2188 feet. In the southwestern part of the State, the sources of Alleghany river are from 1290 (Chantauqua lake), to 2000 feet above the level of the ocean.

To Gentana QUinqUeflora, p. 64, the stations:

Along thicket-covered sidehills above the clifts of Bignose on the Mohawk, Montgomery county. Banks of the outlet of Owasco lake, Caynga county. Common on the sides of ridges ending on the shore of Lake Ontario, from Sodus bay, Wayne county, to the steep banks of Irondequoit bay, and the mouth of Genesee river, Monroe county. 
After G. CRINITA, p.65, the species:

DETONSA, Fries.

Shortened-fringed Gentian.

On the very rerge of bluffs along Lake Ontario west of Irondequoit bay, and on shaded moist sides of ridges, with Campanula rotundifolia and $G$. quinqueflora : low, one to four inches high, one-flowered, most beautiful and delicate plants chiefly; but sometimes higher, and in all respects the same with the form on the wet rocks of Niagara falls. Rare. August, September.

On G. ALBA, the remark :

This plant, which is also abundant in marshes about Owasco lake, may be a white-flowered form of $G$. andrcwsii.

After Polygonum aviculare, var. erectum, p. 69, the species : TENuE, Michaux.

Slender Polygonum.

Common on the dry shady rocky steeps between Yost's and Palatine bridge, Montgomery county. Scarce. July - October.

To P. ARticulatum, the stations:

Abundant in wastes of elear sand between Albany and Schenectady, near Centre station, where sometimes the plants are very large, two feet high. At Oneida lake, it may be found along the shore near the mouth of Fish creek, in sandy copses. Oak openings of Charlotte, Monroe county, Bradley.

To Ceratophyllum Demersum, var. echinatum, p. 71, the range: Common in the waters of the western part of the State aud Lake Ontario.

To Euphorbia polygonifolia, the range :

This plant proves to be as common on the shore of Lake Ontario as on the Coast itself, from Oswego county to Bradduck's point, Monroe county.

To Populus MoniliferA, p. 77, the stations :

Common along the shore of Lake Ontario, from Sodus point, Wayne county, to Braddock's bay, Monroe county; always near the water, and occupying the narrow sandy elevations separating bays, ponds; inlets, marshes from the Lake.

On a low point running ont into Sodus bay there is a long grove of these trees, of a medium height. however, and not over a foot in diameter. But over the ridge against Long and Cranberry ponds there are many fine lofty specimens fifty or sixty feet high, and more than three feet through.

A few trees occur, also, along the outlet of Canandaigua lake, Ontario county, having quite small deltoid leaves, the lower ones on the twigs as broad again as long sometimes; young branches one-half or three-fourths of an inch in diameter, slightiy winged, and a red willow-like bark.

The species:

Angdlata, Aiton.

Angled-stemmed Populus.

Replaces the common form at Braddock's bay, Monroe county; and appears quite frequently in the town of Gorham, Ontario county.

Rare.

To P. BALSAMifera, the range :

Occasional from a few large trees at the mouth of Genesęe river opposite Charlotte, to the base of Cranberry pond, Munroe county, where there are clusters of young and middle-sized growth.

To Typha angustifolia, p. 79, the range:

Bogs along the berm-bank of the Erie canal in Montgomery county.

To SParganium EURYCARPUM, the range :

Common in the marshes of Lake Ontario, bordering all bays and inlets.

To LEMNA GIBBA, p. 80 , the range:

Bays and inlets of Lake Ontario, from marshes northeast of Oswego to Braddock's bay, Monroe county, commonly eovering the water in dense patches : easily distinguished by its thickness, being lens-shaped, arched aboved, below inflated and cellular. 


\section{To NAJAS MAJOR:}

The statement that the habitits given are the only ones known on the Tes-

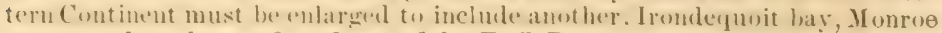
county, where it was first detected by E. J. PICkETT.

The presence of a plant of so well-established maritime character, in a bay of" a freshwater lake, is at wher surprisiug and suspiciois. But the mystery is easily cleared. The belt of Medina saudstone commencing just southwest of Utica, in two or three thin layers below the Oneida conglomerate, each crowded with the characteristic fossil the old Fucoides harlani, extending through the western part of this county, southern Oswego, along the shore of Lake Ontario in northern Cayuga, Wayne, Monroe counties and westward, is everywhere saliferous, abounding in springs and wells from some of which salt was manufactured in old times. A series of these springs, from Vernon, Oneida county, to the Niagara river, originate in the shales and marls of this rock wherever sufficiently near the surface to be subject to leaching by rains, and frequently yield so much saline matter as to affect vegetation. Many occur in Monroe county, along margins and beds of small streams, part of them emptying into Irondequoit bay, one of the largest being located near its head. The water from these springs is briny to the taste, and may accumulate in such a long landlocked inlet of the Lake in sufficient quantity to make the water brackish, just as the overflowings of salt springs atfect Unondaga lake, thus supplying the necessary condition for this marine plant.

To Platanthera rotundfolia, var. oblongifolia, p. 83 :

Mud lake, on whose damp mossy borders this plant has its station. is a small round pond in a depression among the very highest tops of the bills between the Mohawk and Susquehanna vallies, and is abont 1.000 feet above tide in the Hudson river.

To Crpripedium ARIetinum, p. 88 :

The height of Summit lake above tidewater is 1350 feet. Above its head is a large open moss bog, very shaky and full of sloughs, bordered by tamaracks and surrounded by an extensive arbor-vitæe swamp, the locality of many rare plants; the very source both of the Susquehanna river, and also of Otsquago creek descending to the Mohawk.

To Chamelirium LUTedi, p. 91, the station :

Springy rocky steeps just west of Bignose clitfs on the Mohawk, Montgomery county; on the open almost upright sides of the hill.

After Eleocharis obtusa, p. 95, the species:

OLIVACEA, Torrey.

Olive-fruited Eleocharis.

Culms filiform, often diffuse, compressed, sulcate, soft; spike ovate, somewhat obtuse, many-flowered; scales ovate, obtuse, membranaceous; bristles 6 , nearly as long as the nut; style bifid; nut obovate, lenticular, dull ; tubercle conical, rostrate, distinct : TORREY Cyp.

Culms cespitose, erect, diffuse or somewhat decumbent, usually about a span long and nearly a line in diameter, but often dwarfish and slender, of a soft flexible texture, with mucronate sheaths at the base. Spikes 3-4 lines long, $20-30$ flowered, sometimes rather acute. Scales closely or somewhat loosely imbricated : one or two of the lowest shorter and bractlike; the others with a narrow scarious margin. Bristles pretty stout, retrorsely hispid. Stamens 3. Achenium smooth, sometimes a little shining, dark olive when ripe. Tubercle rather free around the base, acute or somewhat obtuse, about one-third the length of the achenium : TORREY Fl. N.Y.

On a sandy peninsula extending into Sodus bay just inside the point, where it is very abundant; equally common on the highest ground in the long Cottonword grove, and on low banks with Cyperus inflexus and Scirpus debilis. Not before detected away from the Coast.

July - October. 
To ScIRPUS PAUCIFlorts, p. 96, the station:

Common at Sodus bar, Warne countr: all over the barren point against Lake Ontario, aud scattered orer the sands peuinsula in the bas with Eleochuris olivacea.

To S. PLANIFOLICS, the station:

Dry pine roods on the bauks of the Hudson above Albaur, and on the opposite side of the river, C.H. Peck.

To Paniccu zanthophysu, p. 121, the station :

In a barren field east of East-Albany, C. H. Peck.

Ir addition to the Flore and later Catologue of the plants of the State br Dr. Torrer, this catalogue inclucles the following native plants :

RANCNCTLTS FLAMMLLA.

NTMPHAA ODORATA, var. MINOR.

NYMPHEA TLBEROSA.

Dextaria heterophyLla.

TCRRITIS GLABRA.

LESPEDEZA STCTEI.

GetM VIRgINiANCM.

Potextilla PARAdoxa.

PiBEs HIRTELLTM.

Ribes RLBRTy.

DIPLOPAPPLS AMYGDALINCS.

Solmdago PLBERULA.

SolidAGO SPECIOSA, var. ANGLSTATA.

SOLIDAGO HOTGHTONII.

Solidago LiYoides.

PrRola sectNdA, var. PCMILA.

DODECATHEON MEADIA.

UTRICULARIA CLANDESTINA.

UTRICULARIA GIBBA.

SCHWALBEA AMERICANA.

LITHOSPERMEM HIRTUM.

Polemonidy CertelecM.

Chenopodicy gLatCum.

ATRIPLEX HASTATA, VAT. OBLONGIFOLIA.

Polygontu nodoscM, Var. INCARNATUM.

Polygondm Careyi.

Polygondu acre.

Callitriche aUtcanalis.

URTICA GRACILIS.

Popelus angulata.

JUniperus SABINA, var. PROSTRATA.
SPARGANITM ETRTCARPCM.

SPARganitu NATANS.

NAJAS MAJOR.

Potamogeton robbinsit.

Potamogeton pRelonges.

SAGITTARIA HETEROPHYLLA.

SagitTaria graminea.

Platanthera rotendifolia, var. OBLONGIFOLIA.

Cypripedicy CANDidey.

Trillital sessile.

TOFIELdiA GLCTINOSA.

JCNCUS DEBILIS.

Xrris belbosa.

Eleocharis compressa.

SCIRPTS PACCIFLORTS.

Scirptes CLINTONII.

ScIRPLS FLUVIATIJ.IS.

CAREX PRAIREA.

CAREX CEPHALOIDEA.

CAREX SCABRTOR.

Carex texella.

CAREX ARGYRANTHA.

CAREX SYCHNOCEPHALA.

Carex lenticularis.

CAREX STRICTIOR.

CAREX GYNANDRA.

Carex emironsit.

Carex rostrata.

CAREX GRAYIr.

Carex leptliformis.

Carex retroctrva.

Carex VAginata.

CAREX WOODII.

Carex GLABRA。 


\author{
CAREX KNIESKERNII. \\ CAREX RICHARDSONII. \\ CAREX Mirata. \\ Carex VASEYI. \\ CAREX hartiI. \\ Carex ampullacea. \\ Carex monile. \\ Carex Vesicaria.
}

Carex physema.

Agrostis perennans.

WOODSIA GLABELLA.

Cystopteris fragilis, var. DENTATA.

Aspidium dilatatum.

Aspidium Boottil.

BOTRYCHIUM LANCEOLATUM.

Among many naturalized plants, the following are athlitional :

Argemone mexicana.

NASTURTIUM OFFICINALE.

NASTURTIUM ARMORACIA.

Reseda LUTEOLA.

Silene inflata.

LiyCINIS VESPERTINA.

Malva moschata

TRIFOLIUM PROCUMBENS.

Medicago maculata.

Prundes spinosa.

ROSA SETIGera.

Fedia olitoria.

Artemisia biennis.
ONOPORDON ACANTHITM.

HYSSOPUS OFFICINALIS.

THYMUS SERPYLLUM.

ATROPA BELLADONNA.

Periploca GR ECA.

Chenopodium URBICUM, var. RHOMBIFOLICM.

Auarantus retroflexus.

RUMEX SANGUINEUS.

RuMEX ACETOSA.

HeMEROCALLIS FULVA.

Bromus racemosus.

LOLIUM TEMULENTUM.

Five marine or coast plants are new to the interior :

Orontium aquaticum.

NAJAS MAJOR.

RUPPIA MARITIMA.
Eleocharis olivacea.

Spartina stricta, var. ALTERNIFLORA.

A few references to localities of rare plants out of the limits of the catalogue have been included, when they were the personal observations of the writer or of former Oneida county botanists, or when communicated for this purpose by others, being no other means of preserving the record.

Original descriptions not generally accessible, have been reproduced, of certain rare or interesting plants and other's first found in this region.

Additions have been inserted during the last season while the printing has been in progress, through the great kindness of JoHs Paterson, esquire; to whom also is to be referred the unusual accuracy and character of the typography of the work.

Uтіса, October, 1865. 


New York Botanical Garden Library

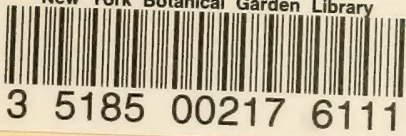


